\title{
WestVirginiaUniversity
}

THE RESEARCH REPOSITORY @ WVU

Graduate Theses, Dissertations, and Problem Reports

2000

\section{Iron and acid removal from acid mine drainage in open limestone systems}

Qingyun Sun

West Virginia University

Follow this and additional works at: https://researchrepository.wvu.edu/etd

\section{Recommended Citation}

Sun, Qingyun, "Iron and acid removal from acid mine drainage in open limestone systems" (2000).

Graduate Theses, Dissertations, and Problem Reports. 3185.

https://researchrepository.wvu.edu/etd/3185

This Dissertation is protected by copyright and/or related rights. It has been brought to you by the The Research Repository @ WVU with permission from the rights-holder(s). You are free to use this Dissertation in any way that is permitted by the copyright and related rights legislation that applies to your use. For other uses you must obtain permission from the rights-holder(s) directly, unless additional rights are indicated by a Creative Commons license in the record and/ or on the work itself. This Dissertation has been accepted for inclusion in WVU Graduate Theses, Dissertations, and Problem Reports collection by an authorized administrator of The Research Repository @ WVU.

For more information, please contact researchrepository@mail.wvu.edu. 


\title{
Iron and Acid Removal from Acid Mine Drainage in Open Limestone Systems
}

\author{
Qingyun Sun \\ Dissertation submitted to the \\ College of Agriculture, Forestry and Consumer Sciences \\ at West Virginia University \\ in partial fulfillment of the requirements \\ for the degree of
}

$\begin{gathered}\text { Doctor of Philosophy } \\ \text { in }\end{gathered}$
Agricultural Sciences

Jeffrey G. Skousen, Ph.D., Chair

Louls M. McDonald, Jr., Ph.D.

Devinder K. Bhumbla, Ph.D.

John C. Sencindiver, Ph.D.

John Renton, Ph.D.

Division of Plant \& Soil Sciences

Morgantown, West Virginia

2000

Keywords: Acid Mine Drainage, Iron Removal, Limestone, Coating, Water Quality Prediction, Open Limestone System Design

Copyright 2000 Qingyun Sun 


\section{ABSTRACT \\ Iron and Acid Removal from Acid Mine Drainage in Open Limestone Systems}

\section{Qingyun Sun}

Passive systems, like wetlands, anoxic limestone drains, and open limestone channels, show promise for treating acid mine drainage (AMD) discharges. Open limestone channels have been developed for over ten years and the treatment effectiveness of AMD by open limestone systems shows wide variation. The variation is due to site conditions (slope and size of the limestone channel) but more importantly to the surface area of the limestone and iron concentrations in the water. Iron in AMD coats the limestone in open limestone systems thereby reducing the surface area available for reaction. Over time, the limestone appears to lose its ability to neutralize acidity and the water quality from open limestone systems is hard to predict.

This study was conducted to understand the effects of limestone surface area, iron concentration of the AMD, and coating thickness of iron on limestone neutralization of AMD. Experiments on limestone surface area showed that the required reaction time to reach a desired final $\mathrm{pH}$ is a function of limestone mass specific area, and initial and final acidity of proton acid solutions. The required reaction time, $t=a A_{M S}{ }^{k}$, can be used to predict the outlet water quality for a hydrogen acid solution in an open limestone system based on a specified limestone particle size and lifetime.

Effects of iron concentration on neutralization of acid solutions by limestone were also researched by batch experiments in the laboratory. The required reaction time for neutralization was modified from previously developed equations by:

$$
t(F e)=t(F e=0)+(42 \ln [F e]+35.1) p H_{f}-176 \ln [F e]-143
$$

where $\mathrm{t}(\mathrm{Fe})$ is the required reaction time for iron acid solutions, $\mathrm{t}(\mathrm{Fe}=0)$ is the reaction time for hydrogen acid solutions, $[\mathrm{Fe}]$ is the iron concentration, and $\mathrm{pH}_{\mathrm{f}}$ is the final $\mathrm{pH}$. In addition, equations were established to estimate limestone neutralization of iron acid solutions, $[\mathrm{Ca}]_{\mathrm{Fe}}=0.309 \mathrm{C}_{\mathrm{T}}+0.27\left[\mathrm{Fe}^{3+}\right]_{\mathrm{i}}+0.448$, where $[\mathrm{Ca}]_{\mathrm{Fe}}$ is the total dissolved $\mathrm{Ca}$ in $\mathrm{mmol} / \mathrm{L}, \mathrm{C}_{\mathrm{T}}$ is the total initial acidity $(\mathrm{meq} / \mathrm{L})$, and $\left[\mathrm{Fe}^{3+}\right]_{\mathrm{i}}$ is the initial iron concentration $(\mathrm{mmol} / \mathrm{L})$.

Thicknesses of the iron coatings on limestone effects on acid neutralization also were evaluated. By the use of different coating thicknesses on limestone, the required reaction time can be calculated by:

$$
\mathrm{t}=\mathrm{f}\left(\mathrm{pH}_{\mathrm{i}}, \mathrm{pH}_{\mathrm{f}},\left[\mathrm{Fe}^{3+}\right], \mathrm{A}_{\mathrm{MS}}, \eta\right)
$$

where $\mathrm{t}$ is required reaction time $(\mathrm{min}), \mathrm{pH}_{\mathrm{f}}$ is the final outlet $\mathrm{pH}, \mathrm{pH}_{\mathrm{i}}$ is initial $\mathrm{pH}$ of the acid solution, $A_{M S}$ is specific surface area of limestone particles, $\left[\mathrm{Fe}^{3+}\right]$ is ferric iron concentration of the acid solution $(\mathrm{mmol} / \mathrm{L})$, and $\eta$ is the term representing the coating effects on limestone dissolution.

With these equations, open limestone channels can be designed with optimized surface area to meet a specified outlet water $\mathrm{pH}$. Predictions can also be made as to the longevity of the treatment and when channels may need replacement. 


\section{ACKNOWLEDGMENTS}

A sincere thanks is for Dr. Jeff Skousen. His encouragement, advice, guidance and patience greatly helped me finish this thesis. During my time with him, I attained good experience and knowledge in the practical treatment of acid mine drainage, which will support my future professional career. Due to my English language problems, Dr. Skousen spent large amounts of time in my Ph.D. study and thesis writing. His kindness, patience, and guidance in my thesis writing and field studies not only encouraged me to finish this Ph.D. program, but it also helped me to improve my English. I feel fortunate to have the benefit of his assistance.

A special thanks goes to Dr. Louis McDonald. Without his great help, especially in experimental design, thesis writing, and chemical theory, I could not complete this thesis within such a short period. He also spent a great amount of time in helping my lab research and thesis writing by his knowledge and abundant research experiences. I do appreciate all that he did for me.

I thank Dr. John Sencindiver, who helped me understand soil science and land issues, and who served on my committee. Thanks also to Dr. D. K. Bhumbla for his lectures and laboratory classes. These professors helped me, an engineering student, understand plant and soil sciences.

I especially want to thank Dr. John Renton for his advice and guidance toward limestone coating and mineral research. With his excellent experience and kindness, I completed the last important part of this research.

Last, special thanks go to my family. It is the love and devotion from my wife, Lanjun, and my son, Yipeng, that made this research possible and encouraged me to finish this Ph.D. study. 


\section{TABLE OF CONTENTS}

TITLE................................................................ i

ABSTRACT .............................................................. ii

ACKNOWLEDGMENTS..........................................

TABLE OF CONTENTS ........................................... iv

LIST OF TABLES ..................................................... v

LIST OF FIGURES................................................ vii

Chapter 1. Overview ........................................... 1

Chapter 2. Introduction.............................................. 6

Chapter 3. Limestone Surface Area and Initial Acidity Effects on AMD Treatment in Open Limestone Channels....................... $\quad 14$

Supporting Information................................. 29

Chapter 4. Iron Effects on Limestone Dissolution in Open Systems....... 31

Chapter 5. Coating Effects on Limestone Dissolution ................... 43

Chapter 6 Open Limestone Channel Design Models and the Prediction of Water Treatment ...................................... 59

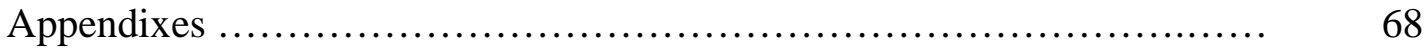

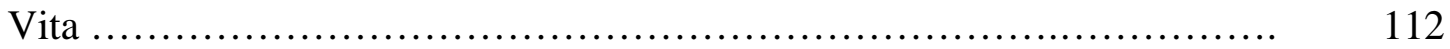

Approval of Examining Committee .................................. 113 


\section{LIST OF TABLES}

$\underline{\text { Table }} \quad \underline{\text { Page }}$

3.1. Limestone specific surface area vs. particle sizes $\bar{d}$.................. 19

3.2. Required retention time in minutes for an initial $\mathrm{pH}$ acid solution $(\mathrm{pH} 2.0$, 2.5, 3.0, 3.5, and 4.0) increased to a final $\mathrm{pH}$ of 5.5, 6.0, 6.5, and 7.0....... 20

3.3. Regressed equations for retention time function of initial $\mathrm{pH}$ and limestone specific surface area........................................... 21

3.4. Limestone surface area decreases as the limestone mass decreases during the life of the open limestone bed.................................... 24

4.1. Calculation of total acidity of five iron solutions with $\mathrm{pH}$ between 2.4 and 3.0 . 38

5.1. Coating thickness as a function of iron solution concentration 47

5.2. Coating effects on outlet water quality............................ 55

6.1 Input Spreadsheet............................................ 61

6.2 Results Spreadsheet.............................................. 62

6.3 Outlet Water Quality Prediction..................................... 63

$\underline{\text { Appendix Table }} \quad \underline{\text { Page }}$

7.1.1 Initial pH 4.0 vs. Particle Sizes................................. 69

7.1.2 Initial $\mathrm{pH} 3.5$ vs. Particle Sizes.................................. 70

7.1 .3 Initial $\mathrm{pH} 3.0$ vs. Particle Sizes................................. 71

7.1 .4 Initial pH 2.5 vs. Particle Sizes................................ 72

7.1.5 Initial pH 2.0 vs. Particle Sizes............................... 73

7.1.6 Limestone Surface Area Experiment ........................... 74

7.1.7 Destination $\mathrm{pH} 5.5,6.0,6.5,7.0$ vs. time of different sizes............. 75

7.2.1 $\mathrm{pH}$ changes with the neutralization of acid solution by limestone

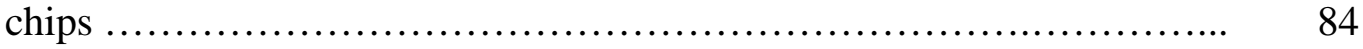

7.2.2 Ca changes with the neutralization of acid solution by limestone chips 
7.3.1 The neutralization test of proton acid solution $(\mathrm{pHi}=3)$ by different limestone chips................................................ 90

7.3.2 The neutralization of proton acid solution $(\mathrm{pHi}=2.5)$ by fresh

limestone chips.

7.3.3 The neutralization of proton acid solution $(\mathrm{pHi}=3.0)$ by fresh limestone chips.

7.3.4 The neutralization of proton acid solution $(\mathrm{pHi}=3.5)$ by fresh limestone chips.

7.3.5 The neutralization of proton acid solution $(\mathrm{pHi}=4.0)$ by fresh

limestone chips.

7.4.1 The neutralization of $0.0008 \mathrm{M}$ iron solutions $\left(\mathrm{FeCl}_{3}\right) \ldots \ldots \ldots \ldots \ldots \ldots . \quad 95$

7.4.2 The neutralization of $0.0016 \mathrm{M}$ iron solutions $\left(\mathrm{FeCl}_{3}\right) \ldots \ldots \ldots \ldots \ldots \ldots . . \ldots 6$

7.4.3 The neutralization of $0.003 \mathrm{M}$ iron solutions $\left(\mathrm{FeCl}_{3}\right) \ldots \ldots \ldots \ldots \ldots \ldots . . . \ldots 7$

7.4.4 The neutralization of $0.008 \mathrm{M}$ iron solutions $\left(\mathrm{FeCl}_{3}\right) \ldots \ldots \ldots \ldots \ldots \ldots . . \ldots 9$

7.4.5 The neutralization of $0.016 \mathrm{M}$ iron solutions $\left(\mathrm{FeCl}_{3}\right) \ldots \ldots \ldots \ldots \ldots \ldots . . \ldots 9$

7.4.6 The neutralization of $0.03 \mathrm{M}$ iron solutions $\left(\mathrm{FeCl}_{3}\right) \ldots \ldots \ldots \ldots \ldots \ldots \ldots . . \ldots 100$

7.4.7 The neutralization of $0.0 \mathrm{M}$ iron solutions $\left(\mathrm{FeCl}_{3}\right) \ldots \ldots \ldots \ldots \ldots \ldots \ldots \ldots . \quad 101$

7.4.8 The neutralization of $0.0005 \mathrm{M}$ iron solution by saran coated limestone... 102

7.4.9 The neutralization of $0.001 \mathrm{M}$ iron solution by saran coated limestone... 103

7.4.10 The neutralization of $0.002 \mathrm{M}$ iron solution by saran coated limestone.. $\quad 104$

7.4.11 The neutralization of 0.004M iron solution by saran coated limestone.. 105

7.4.12 The neutralization of $0.008 \mathrm{M}$ iron solution by saran coated limestone... 106

7.5.1 The neutralization iron solution by 0.0M Fe coated limestone........... 107

7.5.2 The neutralization iron solution by $0.002 \mathrm{M}$ Fe coated limestone......... 108

7.5.3 The neutralization iron solution by $0.004 \mathrm{M}$ Fe coated limestone........ 109

7.5.4 The neutralization iron solution by $0.006 \mathrm{M}$ Fe coated limestone........ 110

$7.5 .5 \mathrm{pH}$ changing rate............................................... 111

7.5.6 Coating thickness vs. iron concentration............................ 111 


\section{LIST OF FIGURES}

Figure $\quad$ Page

1.1. World Fossil Fuel Reserves (IEA,1999).............................. 2

1.2. $\mathrm{CO}_{2}$ Contribution by countries (IEA,1999) ........................... 2

2.1 Limestone particle size............................................. 8

2.2. Qualitative interpretation of surface roughness and oblateness of a particle .......................................................... 9

3.1. Representation of orthogonal axes................................. 16

3.2. Ellipsoid limestone particle size classes effects on neutralization of $0.001 \mathrm{M}$ acid solution.................................................... 19

3.3. The outlet water quality changes with time at different particle size

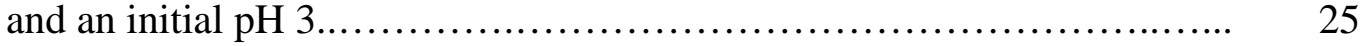

3.4. The outlet water quality changes with time at different initial $\mathrm{pH}$ and optimal particle size $(\mathrm{d}=0.6 \mathrm{~mm})$ or larger particle size $(\mathrm{d}=10 \mathrm{~mm}) \ldots \ldots \ldots . \quad 25$

3.5. The specific surface area vs. the size of sieved limestone.................. 28

3.6. The reaction time required for various acid solutions (pHi 2.0 4.0) neutralized by different limestone surface areas to attain $\mathrm{pH}$ of 5.5....... 28

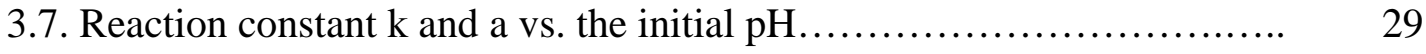

3.8. The reaction time required for various acid solutions (pHi 2.0 4.0) neutralized by different limestone surface areas to attain $\mathrm{pH}$ of $6.0 \ldots \ldots \ldots .$.

3.9. The reaction time required for various acid solutions (pHi 2.0 4.0) neutralized by different limestone surface areas to attain $\mathrm{pH}$ of $6.5 \ldots \ldots \ldots . .30$

3.10. The reaction time required for various acid solutions (pHi 2.0 4.0) neutralized by different limestone surface areas to attain $\mathrm{pH}$ of $7.0 \ldots \ldots \ldots . \quad 30$

4.1. Fe concentration of various iron solutions being neutralized by limestone

4.2. $\mathrm{pH}$ vs. time in iron acid solutions .................................. 35

4.3. Dissolved Ca vs. time in iron acid solution ............................. 36

4.4. The reaction time difference of $\mathrm{pH}$ reaching 5.5, 6.0 and $6.5 \mathrm{vs.}$

ferric concentration by 6.3-11 mm ellipsoid limestone

4.5. Dissolved Ca concentrations vs. the acidity in solutions with and 


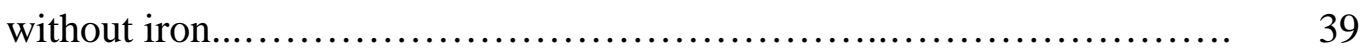

5.1. Schematic representation of coating method ...................... 46

5.2. The coating layer structure .................................... 48

5.3. Cracking on the coating layer.................................... 48

5.4. The micro-pits on the surface of the coating layer..................... 49

5.5. The $\mathrm{CO}_{2}$ gas bubbles cover limestone surface...................... 49

5.6. Pit formation in limestone coating layer.......................... 50

5.7. Coating thickness effects on iron removal........................... 51

5.8. Coating thickness effects on calcium concentration vs. time at

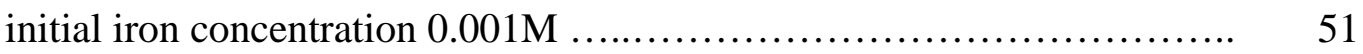

5.9. Coating thickness effects on neutralization rate at initial iron

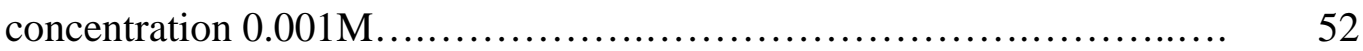

5.10. X-ray diagram of $\mathrm{FeCl}_{3}$ coated layer........................... 57

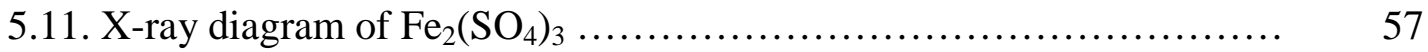

5.12. The X-ray diagram of the coating layer in field limestone systems ..... 58

6.1 Prediction of required time to reach final $\mathrm{pH} 5.5$ vs. different limestone particles and coated limestone square chips.................. 64

6.2 Prediction of required time to reach final $\mathrm{pH} 6.0$ vs. different limestone particles............................................. 64

6.3 Prediction of required time to reach final $\mathrm{pH} 6.5 \mathrm{vs}$. different limestone particles.............................................. 65

6.4 Prediction of required time to reach final $\mathrm{pH} 7.0$ vs. different limestone particles............................................. 65

6.5 Prediction of required time to reach a final $\mathrm{pH}$ in iron acid solutions....... 66

6.6 Prediction of required time to reach a final $\mathrm{pH}$ with coated limestone...... 67

Appendix Figure $\quad \underline{\text { Page }}$

7.1.1 $\mathrm{pH}$ in proton acid solution $\left(\mathrm{pH}_{\mathrm{i}}=2.0\right)$ with ellipsoid limestone particles... 76

7.1.2 $\mathrm{Ca}$ in proton acid solution $\left(\mathrm{pH}_{\mathrm{i}}=2.0\right)$ with ellipsoid limestone particles... $\quad 76$

7.1.3 $\mathrm{pH}$ in proton acid solution $\left(\mathrm{pH}_{\mathrm{i}}=2.5\right)$ with ellipsoid limestone particles... $\quad 77$ 
7.1.4 $\mathrm{Ca}$ in proton acid solution $\left(\mathrm{pH}_{\mathrm{i}}=2.5\right)$ with ellipsoid limestone particles... $\quad 77$

7.1.5 $\mathrm{pH}$ in proton acid solution $\left(\mathrm{pH}_{\mathrm{i}}=3.0\right)$ with ellipsoid limestone particles... $\quad 78$

7.1.6 $\mathrm{Ca}$ in proton acid solution $\left(\mathrm{pH}_{\mathrm{i}}=3.0\right)$ with ellipsoid limestone particles... $\quad 78$

7.1.7 $\mathrm{pH}$ in proton acid solution $\left(\mathrm{pH}_{\mathrm{i}}=3.5\right)$ with ellipsoid limestone particles... $\quad 79$

7.1.8 $\mathrm{pH}$ in proton acid solution $\left(\mathrm{pH}_{\mathrm{i}}=4.0\right)$ with ellipsoid limestone particles... $\quad 79$

7.1.9 Surface area vs. required reaction time at $\mathrm{pH}_{\mathrm{f}} 5.5 \ldots \ldots \ldots \ldots \ldots \ldots \ldots \ldots . \ldots$

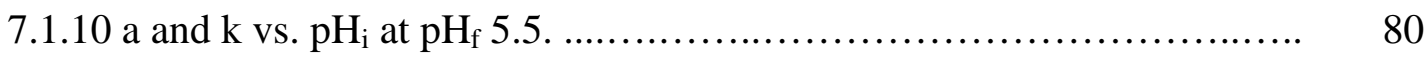

7.1.11 Surface area vs. required reaction time at $\mathrm{pH}_{\mathrm{f}} 6.0 \ldots \ldots \ldots \ldots \ldots \ldots \ldots . . \quad 81$

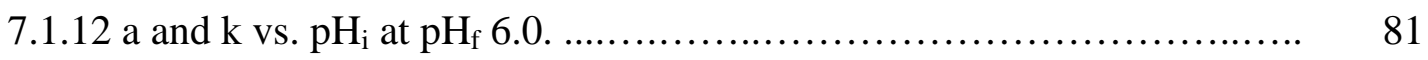

7.1.13 Surface area vs. required reaction time at $\mathrm{pH}_{\mathrm{f}} 6.5 \ldots \ldots \ldots \ldots \ldots \ldots \ldots . . \ldots 2$

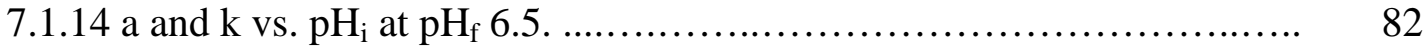

7.1.15 Surface area vs. required reaction time at $\mathrm{pH}_{\mathrm{f}} 7.0 \ldots \ldots \ldots \ldots \ldots \ldots \ldots . . \ldots 3$

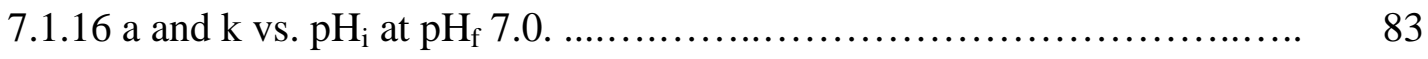

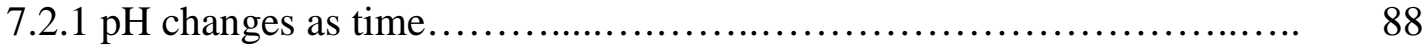

7.2.2 Modeling $\mathrm{pH}$ changes as time.................................... 88

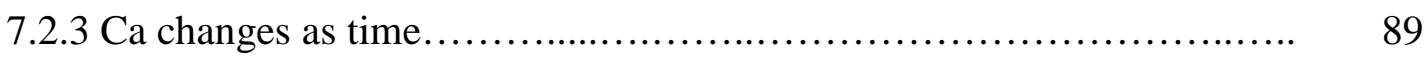

7.2.4 Modeling $\mathrm{Ca}$ changes as time................................... 89 


\section{Chapter 1. Overview}

People have called coal "black gold" or "buried sunshine" as it contains the energy from sunlight that fell on the vast forests and swamps covering large areas of the world at various times in the geologic past. Trees and other plants in primeval forests decayed, forming peat bogs that were buried by soil and rock over millennia. The peat converted into coal over time by pressure and heat generated under the ground.

Coal is the world's most abundant fossil fuel. The total mineable deposit is estimated to be about 1.15 trillion tons (Figure 1.1), which may last over 200 years at the current rates of world consumption. Compared to the reserves of other fossil fuels, coal can last much longer than oil (a supply of about 45 years) and natural gas (a supply for 70 years). In addition, coal is widely distributed in the world, unlike oil and gas reserves which tend to be concentrated in specific regions. In some regions, such as China, coal is the main energy source due to availability and economics. Today, about $40 \%$ of the world's electricity is generated by coal, which accounts for about $70 \%$ of the world's coal production. The second largest use of coal is coke production and it accounts for about $12 \%$ of world coal production, which produces $70 \%$ of the world's steel. The remaining $18 \%$ of the world's coal is used for other industrial and domestic purposes.

Although coal is an important resource and a critical component of our energy supply, the whole process of coal extraction, transportation and use is often accompanied by environmental pollution. Coal combustion produces heat, sulfur and nitrogen oxides, and a particulate residue. Atmospheric nitrogen and sulfur oxides cause acid rain. Atmospheric carbon dioxide from fossil fuel combustion has been implicated in global warming. Heavy metals from the particulate residue (ash) are a potential threat to soil and surface waters. 


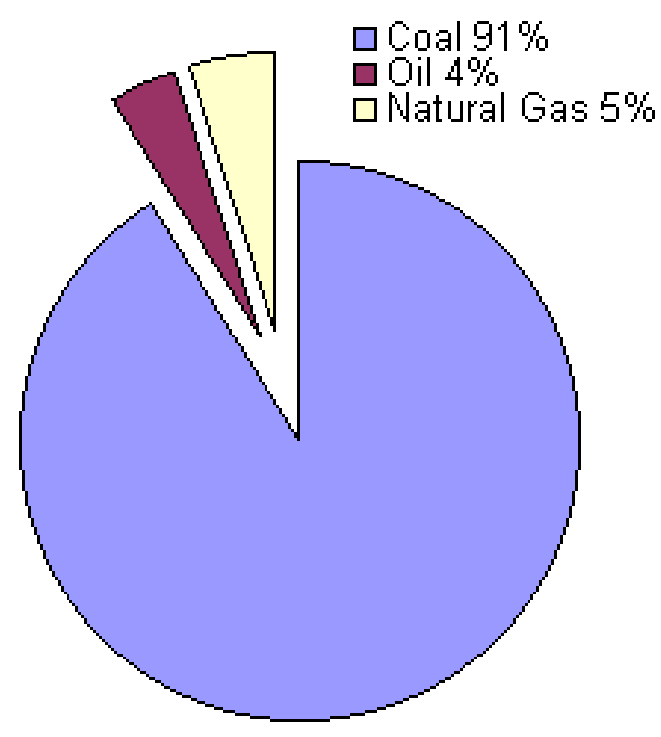

Figure 1.1. World Fossil Fuel Reserves (International Energy Agency, 1999).

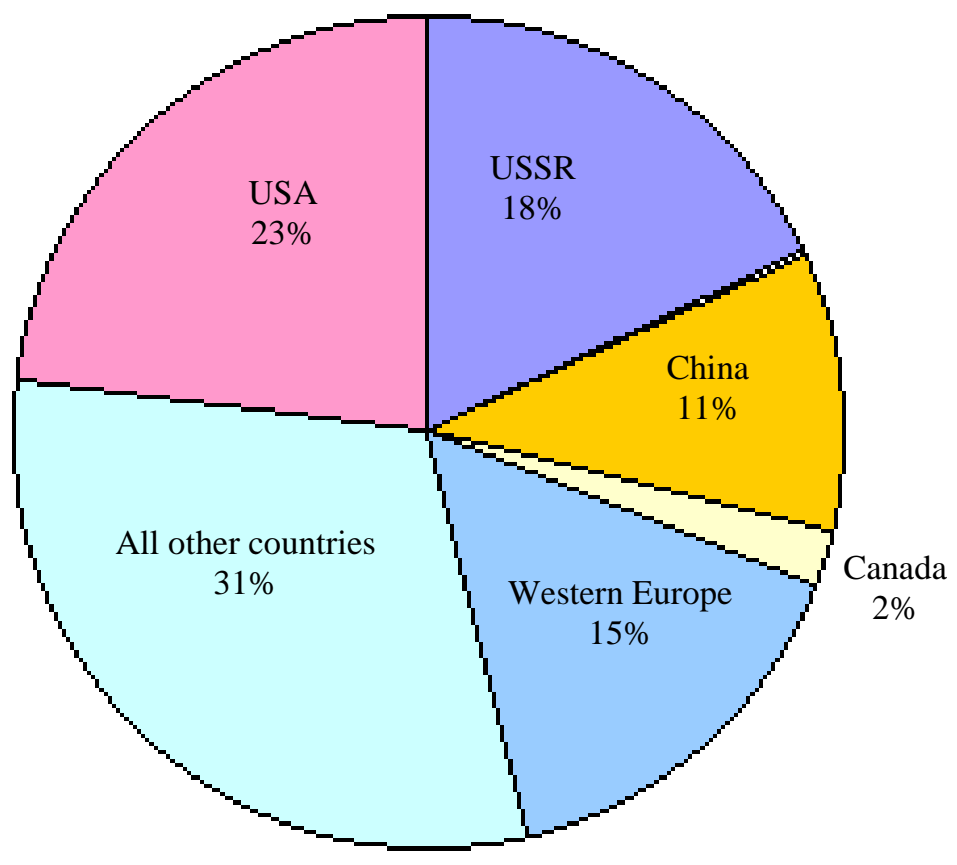

Figure 1.2. $\mathrm{CO}_{2}$ Contribution by country (International Energy Agency, 1999).

Coal transportation systems often cause dust problems and contaminate the air and roads. Coke production is also a major source of air pollution and the released toxic 
gases contaminate the air more than coal combustion. Coal mining operations always produce wastes, some of which may contaminate streams and land. During the mining process, it is necessary to excavate large quantities of waste rock in order to extract the coal, so it often results in subsidence and waste spoil problems. The mine drainage from either active or abandoned mines and wastewater from coal processing plants can be a threat to ground and surface waters. The low $\mathrm{pH}$ and metal ions in acid mine drainage are toxic to aquatic life. Acid mine drainage (AMD) from many mines requires the addition of expensive chemicals for treatment, and this treatment may continue for decades.

Today, AMD pollution has become a worldwide environmental problem, and has contaminated many rivers and water sources in North American mining areas. According to statistics from the U.S. Bureau of Mines, the abandoned coal mines, metal mines and other mining waste have contaminated over 19,000 km of rivers and over 73,000 hectares of lakes and reservoirs in the United States. About $8,000 \mathrm{~km}$ of streams have been seriously contaminated by acid mine drainage in Pennsylvania, West Virginia, Ohio and Maryland. Every year, USA and Canada spend > \$400 million for AMD control and treatment projects, and West Virginia alone annually spends > \$75 million for AMD treatment (USEPA, 1995).

Acid mine drainage has become the biggest environment problem for coal mining in northern West Virginia and south central Pennsylvania due to high sulfur minerals in the rock layers, In these areas, isolation and containment of the potentially toxic parts of the waste is a big challenge. Isolating waste products from water and air prevents, or at least slows down, the onset of AMD. Containing the waste material and runoff (with liners, impervious pads, diversion and collection ditches, etc.) sometimes keeps the pollutants from running off the mine site into groundwater or surrounding streams. Thus, AMD treatment and prevention in this region have become the most urgent tasks for coal operators.

Methods for AMD treatment have been developed based on the site conditions, environmental conditions, and the AMD's chemical composition. Three major approaches have been used to control and treat acid mine drainage: 1) mechanical systems, 2) active (chemical) treatment systems, 3) passive treatment systems. Mechanical systems are an effective way to reduce the formation of AMD by backfilling 
and covering of acid-producing materials, alkaline addition, and limiting the exposure of acid-producing materials to air and water by barriers. Active methods use chemicals such as soda ash, ammonia, caustic soda, hydrated lime, and quicklime to raise $\mathrm{pH}$ and precipitate metals. Although effective, active treatment is best suited for short-term AMD treatment because of its high chemical and maintenance costs.

Passive treatment systems incorporate the use of aerobic and anaerobic wetlands, anoxic limestone drains, successive alkalinity producing systems, and open limestone channels to treat water. While all function in a slightly different way, they all rely on exchange and precipitation reactions and the dissolution of limestone for AMD treatment. The open limestone channel (OLC) is the newest approach to treat AMD. It relies on limestone dissolution for acid neutralization, and even when the limestone is armored with iron, it continues to dissolve based on AMD flow and quality and other site conditions (Ziemkiewicz et al., 1997). Because of the importance of open limestone channels (OLC) in neutralizing AMD, the goal of this research was to understand the iron armoring process and to model the effect of iron on limestone dissolution in open systems.

\section{Reference:}

IEA. 1999. World energy outlook. IEA Publications, London, UK.

Skousen, J. G., and P. F. Ziemkiewicz. 1996. Acid Mine Drainage Control \& Treatment. $2^{\text {nd }}$ Edition. West Virginia University and the National Mine Land Reclamation Center. Morgantown, West Virginia.

USEPA. 1995. Streams with fisheries impacted by acid mine drainage in MD, OH, PA, VA and WV. Region III, Wheeling, WV. 
Ziemkiewicz, P.F., J.G. Skousen, D.L. Brant, P.L. Sterner, and R.J. Lovett. 1997. Acid mine drainage treatment with armored limestone in open limestone channels. J. of Environ. Quality. 26(4):1017-1024. 


\section{Chapter 2. Introduction}

\subsection{Limestone Dissolution}

Limestone is an alkaline material that neutralizes acid. Over the years, limestone has been widely used for acid mine drainage (AMD) treatment in the mining industry due to its low cost and worldwide distribution. West Virginia has a great reserve of limestone that makes it an easy and cheap resource for treating AMD and acidic spoils.

Limestone can dissolve in water to produce alkalinity and neutralize acids. The following reactions describe a solution in equilibrium with excess limestone,

$$
\begin{array}{ll}
\mathrm{CaCO}_{3}(\mathrm{~S}) \Leftrightarrow \mathrm{Ca}^{2+}+\mathrm{CO}_{3}^{2-} & \mathrm{Ksp}=\left[\mathrm{Ca}^{2+}\right]\left[\mathrm{CO}_{3}^{2-}\right]=10^{-8.35} \\
\mathrm{H}_{2} \mathrm{CO}_{3} \Leftrightarrow \mathrm{CO}_{2}(\mathrm{~g})+\mathrm{H}_{2} \mathrm{O} & k_{\mathrm{H}}=\frac{\left[\mathrm{H}_{2} \mathrm{CO}_{3}\right]}{p_{\mathrm{CO}_{2}}} \\
\mathrm{H}_{2} \mathrm{CO}_{3} \Leftrightarrow \mathrm{H}^{+}+\mathrm{HCO}_{3}^{-} & K_{1}=\frac{\left[\mathrm{HCO}_{3}^{-}\right]^{*}\left[\mathrm{H}^{+}\right]}{\left[\mathrm{H}_{2} \mathrm{CO}_{3}\right]}=10^{-6.35} \\
\mathrm{HCO}_{3}^{-} \Leftrightarrow \mathrm{H}^{+}+\mathrm{CO}_{3}^{2-} & K_{2}=\frac{\left[\mathrm{CO}_{3}^{2-}\right]^{*}\left[\mathrm{H}^{+}\right]}{\left[\mathrm{HCO}_{3}^{-}\right]}=10^{-10.33}
\end{array}
$$

Where all species are represented as activities, and $\mathrm{K}_{\mathrm{sp}}, \mathrm{k}_{\mathrm{H}}, \mathrm{K}_{1}$, and $\mathrm{K}_{2}$ are the equilibrium constants.

In open systems, limestone neutralization of acid water involves three ranges based on $\mathrm{pH}$ changes (Berner and Morse, 1974). At low pH (<4.5), limestone dissolution causes the $\mathrm{pH}$ of the solution to increase exponentially. The second region occurs from $\mathrm{pH} 4.5$ to 7, where $\mathrm{pH}$ of the solution increases linearly with time. In the last region, the reaction is approaching equilibrium, so the $\mathrm{pH}$ increases very slowly until equilibrium is reached. 
In nature, many factors influence the limestone dissolution rate and its equilibrium in solutions. Temperature, $\mathrm{CO}_{2}$ partial pressure, acidity, ion strength, limestone, flow rate, hydrology, land geography and particle coating are common factors in the study of limestone dissolution in the field. Environmental conditions such as $\mathrm{PcO}_{2}$ and temperature have a strong influence on limestone dissolution, and its net dissolution rate $(\mathrm{R})$ is affected by each species' activity and their reaction constants (Plummer and Wigley, 1978).

$$
R=k_{1} \alpha_{\mathrm{H}^{+}}+k_{2} \alpha_{\mathrm{H}_{2} \mathrm{CO}_{3}}+k_{3} \alpha_{\mathrm{H}_{2} \mathrm{O}}-k_{4} \alpha_{\mathrm{Ca}^{2+}} \alpha_{\mathrm{HCO}_{3}^{-}}
$$

Where $\mathrm{k}_{1}, \mathrm{k}_{2}$ and $\mathrm{k}_{3}$ are first order rate constants, $\mathrm{k}_{4}$ is the function of temperature and $\mathrm{P}_{\mathrm{CO} 2}$.

Hydrology, geography and water flow rates vary at AMD sources and treatment sites, and their effects on limestone dissolution should be studied independently. Therefore, the key factors that effect limestone neutralization of acid solutions in open limestone systems should be determined. Four of the key factors are: 1) the surface area of the limestone, 2) the initial and final acidity of the solution, 3) the iron concentration of the AMD, and 4) the coating or armoring of the limestone surface.

\subsection{Surface Area Effects on $\mathrm{CaCO}_{3}$ Dissolution}

One of the most important factors influencing limestone neutralization is limestone surface area. To quantitatively estimate the surface area effects, the specific surface area of limestone must be determined. Due to different limestone shapes and sizes in real world AMD treatment facilities, it is difficult to quantitatively measure limestone surface area.

One way of determining the surface area of rock particles is to calculate it based on shape. Bowman (1961) derived an equation to calculate the surface area of an ellipsoid particle: 


$$
S=\frac{\pi c^{2}}{2}+\frac{\pi b}{2 \sqrt{a^{2}-c^{2}}}\left[\left(a^{2}-c^{2}\right) E(\theta, k)+c^{2} F(\theta, k)\right]
$$

where $S$ is the surface area; $\theta$ is given by inverting the expression; $F(\theta, k)$ and $E(\theta, k)$ are the incomplete elliptic integrals; a, b and c are three orthogonal lengths of limestone particle $(a \geq b \geq c)$ (Fig. 2.1).

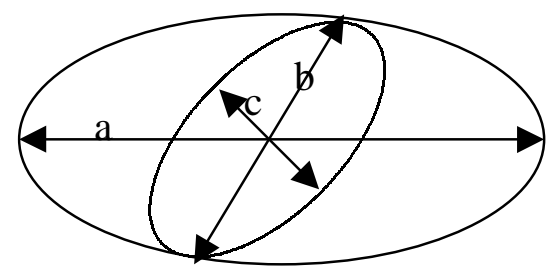

Figure 2.1 Limestone particle size

A second method of calculating surface area of angular rock particles uses shape and roughness factors. Here the surface area is determined by measuring the three orthogonal axes of each rock particle. By the developed curves relating the mean radius to specific rock sizes, Garga et al. (1991) introduced the surface area by the statistical analysis of a rock:

$$
V_{e}=\frac{\pi}{6} a b c
$$

where $\mathrm{V}_{\mathrm{e}}$ is the volume of an ellipsoid particle. For spherical-shaped particles, the surface area can be calculated by:

$$
S=\pi[(a+b+c) / 3]^{2}
$$

By estimating a particle shape factor with mathematical approximation for the surface area of an ellipsoid, the effect of particle shape and surface roughness on the 
hydraulic mean radius can be quantitatively evaluated (Figure 2.2). In fact, the surface roughness has stronger influences than the shapes of crushed rocks (Sabin and Hansen, 1994), where the shape coefficient contains both the shape factor of a perfect ellipsoid and the roughness coefficient for the deviation of a real rock shape from the perfect ellipsoid (Eq.2.9):

$$
r_{e}=R_{\text {oblate }} R_{\text {rough }}
$$

where $r_{e}$ is the general shape coefficient, $R_{\text {oblate }}$ and $R_{\text {rough }}$ are the factors of a perfect ellipsoid particle and a rough rock different from a perfect ellipsoid, respectively.

$$
R_{\text {oblate }}=\frac{A_{v s}(\text { for }-a-\text { perfect }- \text { ellipsoid })}{A_{v s}(\text { for }-a-\text { sphere }- \text { with }-a-\text { diameter }-b)} \approx \frac{S}{\pi a c}
$$

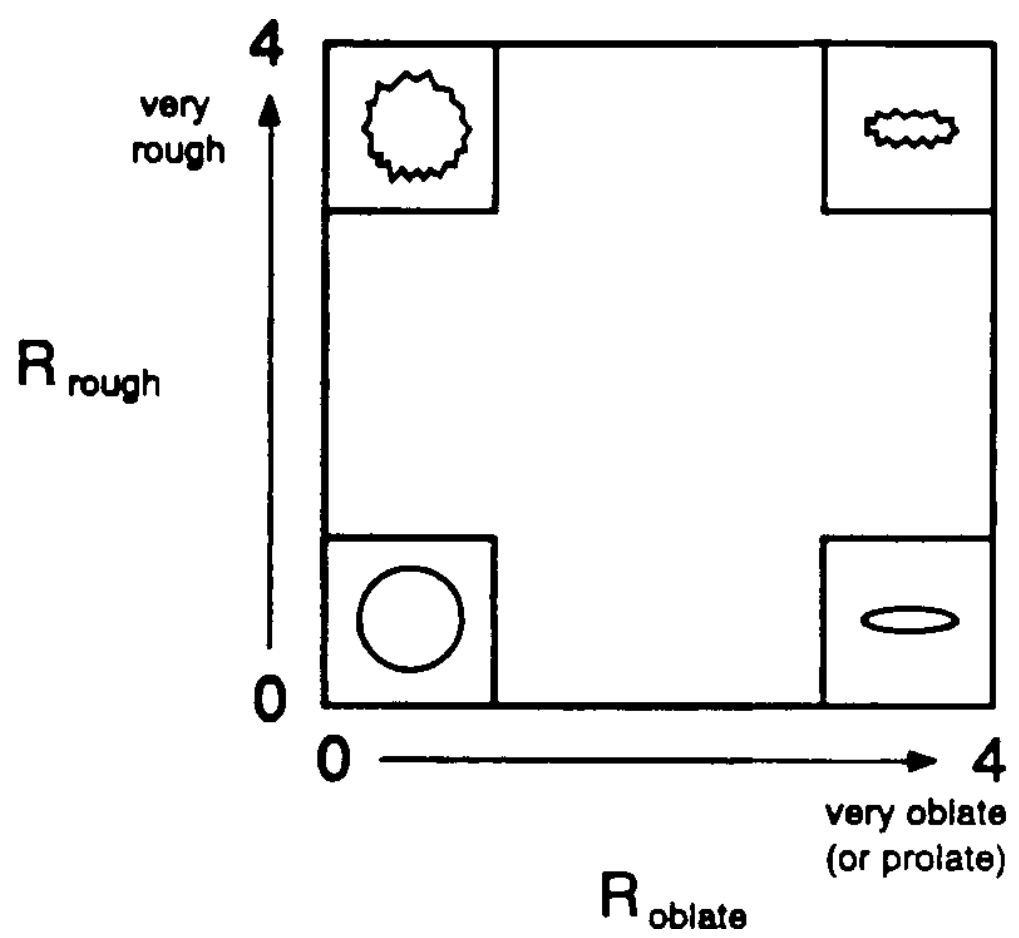

Figure 2.2. Qualitative interpretation of surface roughness and oblateness of a particle. 
Although the shape of a limestone particle affects its surface area, Garga et al. (1991) have shown that the mass-specific surface area $\left(A_{M S}\right)$ of a limestone sample can be estimated by:

$$
A_{M S}=\frac{3.89}{b^{1.08}}
$$

Where $A_{M S}$ is specific surface area and $b$ is the average length of the intermediate orthogonal axes (Figure 2.1).

\subsection{Iron and coating effects on limestone neutralization}

In coal mining areas, iron is commonly found in acid mine drainage as a result of the oxidation of pyrites. The limestone neutralization of acid solutions containing iron is very different from that of hydrogen acid solutions. Iron not only increases acidity of an acid solution and consumes more limestone, but it also forms a coating on limestone surfaces to hinder limestone dissolution.

Studies show that iron precipitation on limestone surfaces forms fine ferric hydroxide particles (Schwertmann and Murad, 1983). These ferric hydroxide particles accumulate and form a coating layer on the limestone surface. X-ray diffraction analysis showed the components and composition of coating minerals that is dependent on the $\mathrm{pH}$ of solutions. Poorly crystalline ferrihydrite $(\mathrm{FeO}-\mathrm{OH})$ was the predominant solid product in the neutralization of acid solutions by calcite (Schwertmann and Murad, 1983). Loeppert et al. (1984) found that lepidocrocite $(\gamma \mathrm{FeO}-\mathrm{OH})$ and goethite $(\alpha \mathrm{FeO}-\mathrm{OH})$ dominated the iron coating of limestone in solutions containing ferrous iron. In the $\mathrm{Fe}\left(\mathrm{ClO}_{4}\right)_{3}$ system, crystalline iron oxides partially coated the calcite surface, and simple iron species subsequently precipitated on existing FeOOH nuclei on the limestone surface (Loeppert et al., 1984).

Past assumptions have held that armored limestone (limestone covered or coated with $\mathrm{Fe}$ or $\mathrm{Al}$ hydroxides) ceased to dissolve, but experiments showed that coated limestone continues to dissolve at about $20 \%$ of the rate of unarmored limestone (Pearson 
and McDonnell, 1977). More work has demonstrated that the rate for armored limestone may be even higher (Ziemkiewicz et al., 1997), but continued dissolution probably depends on $\mathrm{pH}$, thickness of coating, and other variables.

Ziemkiewicz et al. (1994) set up the first order dissolution model to describe limestone dissolution rate:

$$
\ln \frac{C_{F}}{C_{0}}=-k t
$$

Where $\mathrm{t}$ is the retention time, the initial acid concentration is $\mathrm{C}_{\mathrm{F}}$ and final acidity is $\mathrm{C}_{0}$, and $\mathrm{k}$ is the first order reaction constant. Ziemkiewicz et al. (1997) found armored limestone in a series of laboratory experiments was 50 to $90 \%$ as effective as unarmored limestone in neutralizing acid. Ziemkiewicz et al. (1994) suggested that armored limestone was only $50 \%$ as effective as unarmored limestone. The length of the channel and the channel gradient, which affects turbulence and the buildup of coatings, are design factors that can be varied for optimum performance. Ziemkiewicz et al. (1997) also indicated that optimum performance was attained on slopes exceeding $20 \%$, where flow velocities keep precipitates in suspension and, during high flow events containing high

amounts of sediment, clean precipitates from limestone surfaces. In appropriate situations, OLCs are being implemented for long term acid mine drainage treatment. Utilizing OLCs with other passive systems can maximize treatment and metal removal.

\subsection{Open Limestone System Design Criteria}

Open limestone channel design and sizing criteria are currently based on the length of time required for armored limestone (20\% as effective as unarmored limestone) to neutralize the acidity in the AMD. The total amount of limestone in a channel is solely based on acid load (flow $\mathrm{x}$ acid concentration) and this number is multiplied by 5 to correct for the armoring effect. This amount of limestone is then configured into a channel where AMD flows along its length for a specified residence time to neutralize the acid. Based on channel lengths and cross sectional areas that together dictate residence 
time for acid neutralization, Ziemkiewicz et al. (1994) developed an AMD/Time Spreadsheet to estimate AMD treatment effect and cost for open limestone channels, which has been widely used in AMD treatment estimation. In this model, there is no quantitatively consideration of channel slope, limestone particle sizes, flow rate, or the effects of various coating thickness on the limestone. Thus, it is difficult to accurately predict the outlet water quality in both fresh and armored open limestone channels, and it is impossible to estimate the effective lifespan of a limestone channel.

\subsection{Objectives}

The objectives of this research were:

1) to determine acid neutralization by different-sized limestone particles and to evaluate the effects of surface area on limestone dissolution;

2) to evaluate the effects of initial and final acid concentrations $(\mathrm{pH}$ and iron concentration) on limestone dissolution;

3 ) to assess the effects of iron coating thickness and mineralogy on limestone dissolution;

4) to develop a model (spreadsheet) incorporating these variables to more accurately design open limestone channels for acid drainage treatment.

\section{References}

Berner, R. A. and J. W. Morse. 1974. Dissolution kinetics of calcium carbonate in sea water. Am. J. of Sci. 274:108-134.

Bowman, F. 1961. Introduction to Elliptic Functions with Applications. Dover, New York.

Garga, V. K., R. Townsend, and D. Hansen. 1991. A method for determining the surface area of quarried rocks. Geotech. Testing J. 14(1):35-45. 
Loeppert, R. H., L. R. Hossner, and P. K. Amin. 1984. Formation of ferric oxyhydroxides from ferrous and ferric perchlorate in stirred calcareous systems. Soil Sci. Soc. Am. J. 48:677-683.

Pearson, F. H. and A. J. McDonnell. 1977. Characterization of coarse porous media. J of the Env. Eng. Div., ASCE, Vol. 103:615-624.

Plummer, L. N. and T. M. L. Wigley. 1978. The kinetics of calcite dissolution in $\mathrm{CO}_{2^{-}}$ water systems at $5^{\circ}$ to $60^{\circ}$ and 0 to 1.0 atm $\mathrm{CO}_{2}$. American Journal of Science, Vol.278:179-216.

Sabin, G. C. W., and D. Hansen. 1994. The effects of particle shape and surface roughness on the hydraulic mean radius of a porous medium consisting of quarried rock. Geotech. Testing J. 17(1): 43-49.

Schwertmann, U., and E. Murad. 1983. Effect of $\mathrm{pH}$ on the formation of goethite and hematite from ferrihydrite. Clays and Clay Minerals. Vol. 31(4):277-28.

Ziemkiewicz, P.F., J.G. Skousen, and R. Lovett. 1994. Open limestone channels for treating acid mine drainage: a new look at an old idea. Green Lands 24(4):36-41.

Ziemkiewicz, P.F., J.G. Skousen, D.L. Brant, P.L. Sterner, and R.J. Lovett. 1997. Acid mine drainage treatment with armored limestone in open limestone channels. J. of Environ. Quality. 26(4):1017-1024. 


\title{
Chapter 3. Limestone Surface Area and Initial Acidity Effects on Acid Treatment in Open Limestone Channels
}

\begin{abstract}
The neutralization rate of acid solutions with limestone is controlled by initial acidity of the solution, reaction time, and limestone surface area. Limestone surface area depends on the shape and roughness of the particles. Despite the importance of surface area in the acid neutralization process, surface area is not a consideration when designing open limestone channels for the neutralization of acid mine drainage, principally because there is no simple way to measure the surface area of coarse media. The objective of this study is to model the relationship between surface area, reaction time and solution acidity in a simplified system, and to demonstrate the importance of surface area when designing acid treatment systems. The required reaction time is directly related to the surface area according to the power function, $t=a A_{M S}{ }^{k}$; where $\mathrm{A}_{\mathrm{MS}}$ is the limestone's mass specific surface area, a and $\mathrm{k}$ are constants based on initial acidity and final acidity. By use of the derived equation, the outlet water acidity in an open limestone channel can be determined when only proton acidity is present. In addition, open limestone channels can be designed with specified limestone particle sizes and channel length to optimize solution acidity leaving the channels.
\end{abstract}




\section{Introduction}

It has been recognized for years that the dissolution rate of limestone is controlled by surface area (Berner, 1974). Although several investigators have measured the effect of particle size on neutralization rate in the laboratory (Maree et al., 1992, Economou et al., 1996) or speculated on the role of surface area in real systems (Evangelou et al., 1998), surface area effects are seldom considered in the design of acid neutralizing systems. For example, open limestone channels for AMD treatment are typically designed by calculating the mass of limestone needed to neutralize a given quantity of acid, and multiplying by a correction factor (e.g. 10-20 times the annual acid load). The reason for this is that there is no simple method to calculate the surface area of a limestone sample.

For coarse materials, surface area can be estimated using a shape factor and some representative length or from statistical derivation based on some representative length (Allen, 1975). Different methods may give different results for the same-sized materials (Allen, 1975). The physical or chemical adsorption methods based on the well-known Brunauer, Emmett and Teller (B.E.T.) equation used to measure the surface area of fine particles are not appropriate because of the low specific surface area of coarse particles. Coating methods such as the use of nickel or saran ignore surface roughness (Garga et al., 1991). Though microscopes can observe every surface of macro particles, statistical methods must be used to determine the particle size distribution. For example, industry often uses the shape coefficient to estimate the surface area for large $(1-50 \mathrm{~mm})$ mineral particles, especially for coal, dolomite, silica, diamonds, etc (Allen, 1975).

Although the shape of a particle affects its surface area, Garga et al. (1991) have shown that the mass-specific surface area of a limestone sample can be estimated by:

$$
A_{M S}=\frac{3.89}{b^{1.08}}
$$

Where, $b$ is the average length of the intermediate orthogonal axis (Figure 3.1). Sabin and Hansen (1994) used the diameter $(\bar{d})$ and surface area (S) of a sphere of 
equivalent volume, and a shape factor $\left(r_{e}\right)$ to determine the volume and specific surface area of crushed rock. The shape factor was given as:

$$
r_{e}=R_{\text {oblate }} R_{\text {rough }}
$$

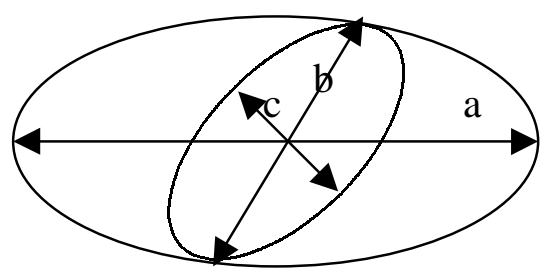

Figure 3.1. Representation of orthogonal axis.

where $r_{e}$ is the general shape coefficient; $R_{\text {oblate }}$ represents deviations of an ellipsoid rock from a perfect sphere and $R_{\text {rough }}$ represents the deviations of an actual rock from an ellipsoid. The surface area of an actual rock was then calculated as (Sabin and Hansen, 1994):

$$
\mathrm{S}_{\mathrm{A}}=\mathrm{r}_{\mathrm{e}} \mathrm{S}
$$

Previous studies on limestone neutralization primarily focused on a single parameter such as surface area, temperature, $\mathrm{P}_{\mathrm{CO} 2}$, or water acidity; the interaction among these factors was not reported. For fresh limestone, no effective models have been developed to describe the interaction of limestone surface condition, water retention time, and water acidity during the neutralization process. So, it is difficult to quantitatively predict limestone consumption and assess the treatment effects at AMD treatment sites using limestone for acid neutralization. Therefore, it is difficult to accurately predict the outlet water quality after passage through limestone treatment systems.

Quantitatively defining the effects of limestone particle size and water retention time on acidity changes is a potentially useful contribution to the design of an effective AMD limestone treatment system. By modeling optimal limestone size based on its surface area, hydrogen ion concentration, and the reaction time, a limestone treatment 
system such as an open limestone channel can be designed with the optimal length (retention time) and limestone particle size distribution to optimize its outlet water quality or final acid concentration. Based on this derived relationship, when any three of the four factors (initial acidity, limestone particle sizes, retention time and final $\mathrm{pH}$ ) are known, the fourth can be calculated. The objective of this research was to model these relationships by using data from laboratory experiments.

\section{Materials and Methods}

Laboratory experiments were conducted using different sized and shaped limestone to neutralize acid solutions. All limestone came from Germany Valley, West Virginia, which has a $\mathrm{CaCO}_{3}$ equivalent of about $98.5 \%$ (Zurbuch, 1996). Ellipsoidal limestone from the Blackwater River Limestone Drum Station, which were oringinated from Germany Valley, was sieved into five diameter classes (2.0 4.75, 4.75 6.3, 6.3 11, 11 19 and 19 25 mm) and washed with dilute $\mathrm{HCl}$ acid and deionized water.

The volume $(\mathrm{V})$, number of particles $(\mathrm{n})$, and exact mass $(\mathrm{m})$ of an approximately $100 \mathrm{~g}$ sample of each size class was determined. The average equivalent spherical diameter $(\bar{d})$ was calculated as,

$$
\bar{d}=\sqrt[3]{\frac{6 V}{n \pi}}
$$

and the shape factor was calculated using Equation 2. Because the limestone particles were smooth and ellipsoidal, $R_{\text {rough }}$ was set to 1 and $R_{\text {oblate }}$ was estimated to be 1.90 . The total surface area of the sample was calculated as:

$$
S_{A}=\pi \bar{d}^{2} n
$$

and the spherical limestone mass-specific surface area $\left(A_{M S}\right)$ is: 


$$
A_{M S}=\frac{n \pi \bar{d}^{2}}{m}
$$

Considering the actual rock factor $\left(\mathrm{R}_{\text {oblate }} 1.90\right)$, the mass specific area $\left(\mathrm{A}^{0}{ }_{\mathrm{MS}}\right)$ of limestone particles may be estimated by the following:

$$
A_{M S}^{0}=\frac{n \pi \bar{d}^{2}}{m} R_{\text {oblate }}
$$

Batch experiments were designed to use the ellipsoidal limestone to neutralize $400 \mathrm{~mL}$ of a stirred $\mathrm{HCl}$ acid solution in a $600-\mathrm{mL}$ beaker. During the experiment, small solution samples $(0.9 \mathrm{~mL})$ were taken at predetermined time intervals and analyzed. The $\mathrm{pH}$ of the solution was measured at the time of extraction (Accumet $25 \mathrm{pH}$ meter, Fisher Scientific Company, Accu-pHast Electrode), and the withdrawn samples were analyzed for $\mathrm{Ca}$ concentration with either Inductively Coupled Plasma (Perkin Elmer P4000) or Atomic Absorption Spectroscopy (Perkin Elmer 5000).

\section{Results and Discussion}

The smaller-sized particles had larger mass-specific surface area and, since mass was constant, larger total surface area (Table 3.1). Based on a correspondence between average sieve size (d) and average diameter $(\bar{d})$, an equation similar to Equation 1 was derived:

$$
\mathrm{A}_{\mathrm{ms}}=3.6635 \mathrm{~d}^{-0.9828}
$$

where $A_{m s}$ is mass-specific surface area of ellipsoid limestone, and $d$ is the average sieve size. In comparing Equations 1 and 8, the only difference is that the average sieve size (d) replaces $b$, the average length of intermediate axis. 
Table 3.1. Limestone specific surface area vs. particle sizes $\bar{d}$.

\begin{tabular}{ccccccc}
\hline Sieve Sizes & $\mathrm{n}$ & $\mathrm{V}$ & Mass & $\bar{d}$ & Total S & Specific $\mathrm{A}_{\mathrm{MS}}$ \\
\hline $\mathrm{mm}$ & & $\mathrm{cm}^{3}$ & $\mathrm{~g}$ & $\mathrm{~mm}$ & $\mathrm{~cm}^{2}$ & $\mathrm{~cm}^{2} / \mathrm{g}$ \\
$2.0 \sim 4.75$ & 820 & 37.0 & 100.0 & 4.4 & 507.8 & 9.7 \\
$4.75 \sim 6.3$ & 270 & 37.0 & 99.9 & 6.4 & 349.6 & 6.7 \\
$6.3 \sim 11.0$ & 74 & 36.9 & 99.7 & 9.9 & 226.9 & 4.3 \\
$11.0 \sim 19.0$ & 15 & 37.2 & 100.6 & 16.9 & 134.3 & 2.5 \\
$19.0 \sim 25.0$ & 4 & 37.2 & 100.6 & 26.2 & 86.4 & 1.6
\end{tabular}

$\mathrm{n}=$ the number of $100 \mathrm{~g}$ limestone particles; $\mathrm{V}=$ volume of $100 \mathrm{~g}$ limestone particles; $\bar{d}=$ average diameter of particles; Total $\mathrm{S}=$ total surface area of limestone particles.

The importance of surface area is illustrated in Figure 3.2. Both systems have the same initial $\mathrm{pH}$ (3.0) and the same equilibrium $\mathrm{pH}$ (8.2), but the paths to that equilibrium are very different. For example, it takes 2.3 times longer to reach $\mathrm{pH} 7$ when average sieve size increased from 3.4 to $22 \mathrm{~mm}$ (or $9.7-1.6 \mathrm{~cm}^{2} / \mathrm{g}$ ). Table 3.2 contains the observed reaction time required to reach a specific destination $\mathrm{pH}$ for several initial $\mathrm{pH}$ and surface area combinations.

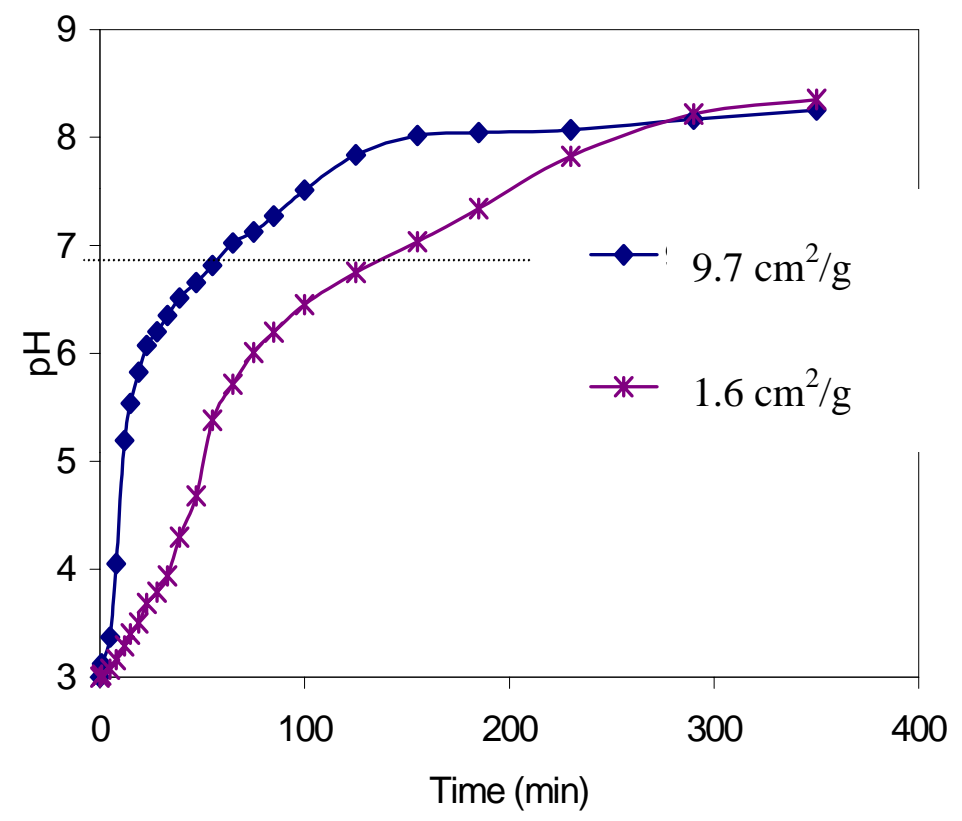

Figure 3.2. Ellipsoid limestone particle size classes effects on neutralization of $0.001 \mathrm{M}$ acid solution. 
Table 3.2. Required retention time in minutes for an initial acid solution of $\mathrm{pH} 2.0,2.5$, 3.0, 3.5, and 4.0 to be increased to a final $\mathrm{pH}$ of 5.5, 6.0, 6.5, and 7.0.

\begin{tabular}{|c|c|c|c|c|c|}
\hline \multirow{2}{*}{$\begin{array}{c}\text { Specific } \\
A_{M S}\end{array}$} & \multicolumn{5}{|c|}{ Final $\mathrm{pH} 5.5$} \\
\hline & $\mathrm{pHi}=2.0$ & $\mathrm{pHi}=2.5$ & $\mathrm{pHi}=3.0$ & $\mathrm{pHi}=3.5$ & $\mathrm{pHi}=4.0$ \\
\hline $\mathrm{cm}^{2} / \mathrm{g}$ & \multicolumn{5}{|c|}{----------------------- $\quad$ min $\quad----------------------$} \\
\hline 9.7 & 40 & 23 & 14 & 8 & 3 \\
\hline 6.7 & 48 & 30 & 16 & 10 & 4.5 \\
\hline 4.3 & 65 & 40 & 21 & 15 & 5.5 \\
\hline 2.5 & 100 & 60 & 50 & 25 & 6 \\
\hline 1.6 & 130 & 90 & 58 & 42 & 17 \\
\hline$a$ & 183.2 & 125.7 & 94.2 & 62.6 & 19.2 \\
\hline \multirow[t]{2}{*}{$\mathrm{k}$} & -0.68 & -0.76 & -0.89 & -0.94 & -0.83 \\
\hline & \multicolumn{5}{|c|}{ Final $\mathrm{pH} 6.0$} \\
\hline 9.7 & 77 & 37 & 22 & 13 & 4 \\
\hline 6.7 & 93 & 55 & 24 & 15 & 7 \\
\hline 4.3 & 130 & 75 & 43 & 20 & 8 \\
\hline 2.5 & 175 & 95 & 54 & 33 & 10 \\
\hline 1.6 & 180 & 125 & 75 & 52 & 22 \\
\hline a & 256.2 & 178.7 & 108.4 & 71.1 & 27.9 \\
\hline \multirow[t]{2}{*}{$\mathrm{k}$} & -0.51 & -0.65 & -0.72 & -0.79 & -0.83 \\
\hline & \multicolumn{5}{|c|}{ Final pH 6.5} \\
\hline 9.7 & 220 & 90 & 37 & 24 & 7 \\
\hline 6.7 & 255 & 110 & 44 & 26 & 9 \\
\hline 4.3 & 255 & 140 & 58 & 31 & 12 \\
\hline 2.5 & 265 & 160 & 83 & 47 & 14 \\
\hline 1.6 & 270 & 190 & 105 & 75 & 24 \\
\hline$a$ & 281.1 & 273.9 & 142.3 & 91.3 & 29.8 \\
\hline \multirow[t]{2}{*}{$\mathrm{k}$} & -0.09 & -0.41 & -0.60 & -0.64 & -0.64 \\
\hline & \multicolumn{5}{|c|}{ Final $\mathrm{pH} 7.0$} \\
\hline 9.7 & 400 & 240 & 75 & 36 & 11 \\
\hline 6.7 & 410 & 240 & 84 & 37 & 15 \\
\hline 4.3 & 420 & 250 & 95 & 45 & 16 \\
\hline 2.5 & 415 & 260 & 125 & 70 & 17 \\
\hline 1.6 & 440 & 270 & 155 & 100 & 30 \\
\hline$a$ & 443.6 & 278.1 & 184.2 & 123.9 & 32.6 \\
\hline k & -0.04 & -0.07 & -0.41 & -0.60 & -0.47 \\
\hline
\end{tabular}

The initial acidity of the solution also showed a strong influence on the required reaction time. High acidity or low $\mathrm{pH}$ solutions required more time than did high initial $\mathrm{pH}$ or lower acidity solutions. By regressing reaction time against initial $\mathrm{pH}$ and limestone specific surface area, we attained the general equation:

$$
t=a A_{M S}^{k}
$$


where $\mathrm{t}$ is reaction time $(\mathrm{min}), \mathrm{k}$ is the regressed exponential constant for every initial $\mathrm{pHi}$, a is the regressed coefficient constant for every initial $\mathrm{pH}_{\mathrm{i}}$, and $\mathrm{A}_{\mathrm{MS}}$ is limestone specific surface area $\left(\mathrm{cm}^{2} / \mathrm{g}\right)$.

Tabulated values for a and $\mathrm{k}$ are listed in Table 3.2, and Equations 10 and 11 are general functions for $\mathrm{k}$ and $\mathrm{a}$ :

$$
\begin{aligned}
& \mathrm{k}=\mathrm{k}_{1} \mathrm{pHi}+\mathrm{k}_{2} \\
& \mathrm{a}=\mathrm{a}_{1} \mathrm{pH}_{\mathrm{i}}+\mathrm{a}_{2}
\end{aligned}
$$

where $\mathrm{a}_{1}$ and $\mathrm{a}_{2}$ are the constants related to the final $\mathrm{pH} ; \mathrm{k}_{1}$ and $\mathrm{k}_{2}$ are the constants corresponding to the final $\mathrm{pH}$; and $\mathrm{pH}_{\mathrm{i}}$ is the initial $\mathrm{pH}$.

Combining equations 9,10 and 11 , the general equation of the reaction time for acid neutralization by limestone to attain each of four destination $\mathrm{pH}$ values was determined (Table 3.3). Thus, the increase of specific surface area of limestone results in shorter reaction time, translating into a faster reaction rate. As the initial acidity increases (or $\mathrm{pH}$ decreased), the reaction time to reach $\mathrm{pH} 5.5$ increases. Even though low $\mathrm{pH}$ solutions reacted faster with limestone, the increase in the amount of acid to be neutralized required more time.

Table 3.3 Regressed equations for retention time function of initial $\mathrm{pH}$ and limestone specific surface area.

\begin{tabular}{cccc}
\hline Final $\mathrm{pH}$ & $\begin{array}{c}\text { Regressed function } \\
\mathrm{a}=\mathrm{a}_{1} \mathrm{pHi}+\mathrm{a}_{2}\end{array}$ & $\begin{array}{c}\text { Regressed k function } \\
\mathrm{k}=\mathrm{k}_{1} \mathrm{pHi}+\mathrm{k}_{2}\end{array}$ & $\begin{array}{c}\text { General Equation } \\
t=a A_{M S}{ }^{k}\end{array}$ \\
\hline 5.5 & $\mathrm{a}=-78.234 \mathrm{pHi}+331.7$ & $\mathrm{k}=-0.0952 \mathrm{pHi}-0.5343$ & $t=\left(331.7-78.234 p H_{i}\right) A_{M S}{ }^{-0.0952 p H i-0.5343}$ \\
& $\left(\mathrm{R}^{2}=0.987\right)$ & $\left(\mathrm{R}^{2}=0.53\right)$ & \\
6.0 & $\mathrm{a}=-112.82 \mathrm{pHi}+466.92$ & $\mathrm{k}=-0.1535 \mathrm{pHi}-0.2415$ & $t=\left(466.92-122.82 p H_{i}\right) A_{M S}{ }^{-0.1535 p H i-0.2415}$ \\
& $\left(\mathrm{R}^{2}=0.975\right)$ & $\left(\mathrm{R}^{2}=0.946\right)$ & \\
6.5 & $\mathrm{a}=-137.06 \mathrm{pHi}+574.84$ & $\mathrm{k}=-0.2642 \mathrm{pHi}+0.314$ & $t=(574.84-137.06 p H i) A_{M S}{ }^{-0.2642 p H i+0.314}$ \\
& $\left(\mathrm{R}^{2}=0.947\right)$ & $\left(\mathrm{R}^{2}=0.795\right)$ & \\
7.0 & $\mathrm{a}=-195.25 \mathrm{pHi}+798.22$ & $\mathrm{k}=-0.2758 \mathrm{pHi}+$ & $t=(798.22-195.25 \mathrm{pHi}) A_{M S}{ }^{-0.2758 p H i+0.5081}$ \\
& $\left(\mathrm{R}^{2}=0.965\right)$ & $0.5081\left(\mathrm{R}^{2}=0.767\right)$ & \\
\hline
\end{tabular}


From Table 3.3, we derived the general equation (Eq. 12) for the required reaction time to neutralize the acidity from an initial to final $\mathrm{pH}$.

$$
\begin{aligned}
& t=a A_{M S}^{k}=\left(a_{1} p H_{i}+a_{2}\right) A_{M S}^{k_{1} p H i+k_{2}} \\
& \mathrm{a}_{1}=-75.058 \mathrm{pH}_{\mathrm{f}}+338.27 \\
& \mathrm{a}_{2}=0.8053 \mathrm{pH}_{\mathrm{f}}^{3.5346} \\
& \mathrm{k}_{1}=-0.1305 \mathrm{pH}_{\mathrm{f}}+0.6185 \\
& \mathrm{k}_{2}=0.7365 \mathrm{pH}_{\mathrm{f}}-4.5918 \\
& t=\left[\left(-75.08 p H_{f}+338.27\right) p H_{i}+0.8053 p H_{f}^{3.5346}\right] A_{M S}^{\left(-0.1305 p H_{f}+0.6185\right) p H i+\left(0.7365 p H_{f}-4.5918\right)}
\end{aligned}
$$

Where $\mathrm{pH}_{\mathrm{f}}$ is the final $\mathrm{pH}$ and $\mathrm{pH}_{\mathrm{i}}$ is initial $\mathrm{pH}$, and $\mathrm{A}_{\mathrm{MS}}$ is mass specific surface area.

So, whenever the outlet acidity (or $\mathrm{pH}_{\mathrm{f}}$ ) and inlet water acidity (or $\mathrm{pHi)}$ of an acid solution is fixed, the required reaction time can be determined for specified limestone particle sizes. Once we know the limestone particle sizes, the length, width and depth of a limestone bed can be determined for an open limestone channel by Equation 12 .

\section{Example}

To show how Equation 12 can be used to optimize a limestone treatment system, the following example is given. Suppose an acid source has $1000 \mathrm{~L} / \mathrm{min}$ of effluent with an initial $\mathrm{pH}$ of 3.0 and no iron (acidity $10^{-3} \mathrm{M}$ or $50 \mathrm{mg} / \mathrm{L}$ as $\mathrm{CaCO}_{3}$ ). If the final $\mathrm{pH}$ is designated as 7.0, the open limestone channel is designed for 10 years and the retention time is 60 minutes, the final $\mathrm{pH}$ and the limestone consumption can be predicted at any time during the life of the open limestone channel. 


\begin{tabular}{|c|c|c|}
\hline $\begin{array}{l}\text { Inflow: } \\
\mathrm{pH}_{\text {initial }}=3.0 \\
\text { Flow rate } \\
Q=1000 \mathrm{~L} / \mathrm{min}\end{array}$ & $262800 \mathrm{~kg}$ Limestone & $\begin{array}{l}\text { Outflow: } \\
\mathrm{pH}_{\text {final }}=7.0 \\
\text { Flow rate: } \\
\mathrm{Q}=1000 \mathrm{~L} / \mathrm{min}\end{array}$ \\
\hline
\end{tabular}

Acid load:

$$
\begin{aligned}
& \mathrm{A}=10^{-p H_{0}}(e q / \mathrm{L}) Q(\mathrm{~L} / \mathrm{min}) * 365(\text { days } / \text { year }) * 24(\mathrm{hr} / \text { day }) * 60(\mathrm{~min} / \mathrm{hr}) * 50(\mathrm{~g} / \mathrm{eq}) \\
& =26,280,000 \mathrm{~g} \mathrm{CaCO}_{3} / \text { year. }
\end{aligned}
$$

The total required limestone for 10 years is:

$\mathrm{W}_{0}=10^{*} \mathrm{~A}=262,800,000 \mathrm{~g}=262,800 \mathrm{~kg}$.

Optimized limestone surface area is (Eq. 12):

$$
\begin{aligned}
A_{M S 0}= & \left(\frac{t(\min )}{\left(-75.08 p H_{f}+338.27\right) p H_{i}+0.8053 p H_{f}^{3.5346}}\right)^{\frac{1}{\left(-0.1305 p H_{f}+0.6185\right) p H i+0.7365 p H_{f}-4.5918}} \\
& =55.91 \mathrm{~cm}^{2} / \mathrm{g}
\end{aligned}
$$

The optimal sieve size of limestone particles is (Eq. 8):

$$
\mathrm{d}_{0}=\left(\frac{A_{M S}\left(\mathrm{~cm}^{2} / \mathrm{g}\right)}{3.6635}\right)^{-\frac{1}{0.9828}}=\left(\frac{59.91}{3.6635}\right)^{-\frac{1}{0.9828}}=0.0614 \mathrm{~cm}
$$

Total surface area:

$$
S_{0}=A_{M S 0}\left(\mathrm{~cm}^{2} / \mathrm{g}\right) * W_{0}(\mathrm{~g}) \approx 1.57 * 10^{10} \mathrm{~cm}^{2}
$$

After running for one year, the limestone loss is $\mathrm{A}$ and limestone remaining is $\mathrm{W}_{1}$ :

$$
\begin{aligned}
& \mathrm{A}=\left(10^{-p H_{i}}-10^{-p H_{1}}\right) Q * 365 * 24 * 60 \\
& \mathrm{~W}_{1}=\mathrm{W}_{0}-\mathrm{A}
\end{aligned}
$$

Since $10^{-p H_{i}}>>10^{-p H_{1}}, \mathrm{~W}_{1} \approx W_{0}-\mathrm{A}=\left(1-\frac{1}{10}\right) W_{0}$. 
So, one tenth of the limestone mass is lost in the first year, which results in a volume decrease of $1 / 10$. Thus, the average diameter and the total surface area in the end of the first year are:

$$
\begin{aligned}
& d_{1}=\left(1-\frac{1}{10}\right)^{\frac{1}{3}} d_{0}=0.059 \mathrm{~cm} \\
& S_{1}=\left(1-\frac{1}{10}\right)^{\frac{2}{3}} S_{0}=1.46 * 10^{10} \mathrm{~cm}^{2}
\end{aligned}
$$

In the second year, limestone loss will again be about $1 / 10$ or $52560000 \mathrm{~g}$ $\left(10^{-p H_{i}}>>10^{-p H_{1}}\right)$, so the remaining limestone will be only about $80 \%$ of the original mass. $\mathrm{W}_{2} \approx(1-2 * 10 \%) \mathrm{W}_{0}$.

For any year $\mathrm{n}$, the mass, diameter and surface area is given as:

$$
\begin{aligned}
& \mathrm{W}_{\mathrm{n}} \approx(1-\mathrm{n} * 10 \%) \mathrm{W}_{0} \\
& d_{n}=(1-10 \% * n)^{\frac{1}{3}} d_{0} \\
& S_{n}=(1-10 \% * n)^{\frac{2}{3}} S_{0}
\end{aligned}
$$

Calculations for years 0 to 10 are given in Table 3.4.

Table 3.4. Limestone surface area decreases as the limestone mass decreases during the life of the open limestone channel.

\begin{tabular}{ccccc}
\hline Time & Mean Diameter & LS Mass & $\begin{array}{c}\text { Total surface } \\
\text { area }\end{array}$ & $\begin{array}{c}\text { Surface area } \\
\text { changes S/So }\end{array}$ \\
\hline Year & $\mathrm{cm}$ & $\mathrm{kg}$ & $\mathrm{x}^{10^{10} \mathrm{~cm}^{2}}$ & $\%$ \\
0 & 0.061 & 262800 & 1.57 & 100 \\
1 & 0.059 & 236520 & 1.46 & 93 \\
2 & 0.057 & 210240 & 1.35 & 86 \\
3 & 0.055 & 183960 & 1.24 & 79 \\
4 & 0.052 & 157680 & 1.12 & 71 \\
5 & 0.049 & 131400 & 0.99 & 63 \\
6 & 0.045 & 105120 & 0.85 & 54 \\
7 & 0.041 & 78840 & 0.70 & 45 \\
8 & 0.036 & 52560 & 0.54 & 34 \\
9 & 0.029 & 26280 & 0.34 & 22 \\
10 & 0.000 & 0 & 0.00 & 0 \\
\hline
\end{tabular}

As limestone is continually removed from the system, the particle size and total surface area remaining must decrease. Given the relationship between neutralization rate 
and particle size for a fixed reaction time (Figure 3.2 and Eq. 12), the outlet pH must decrease (Figure 3.3).

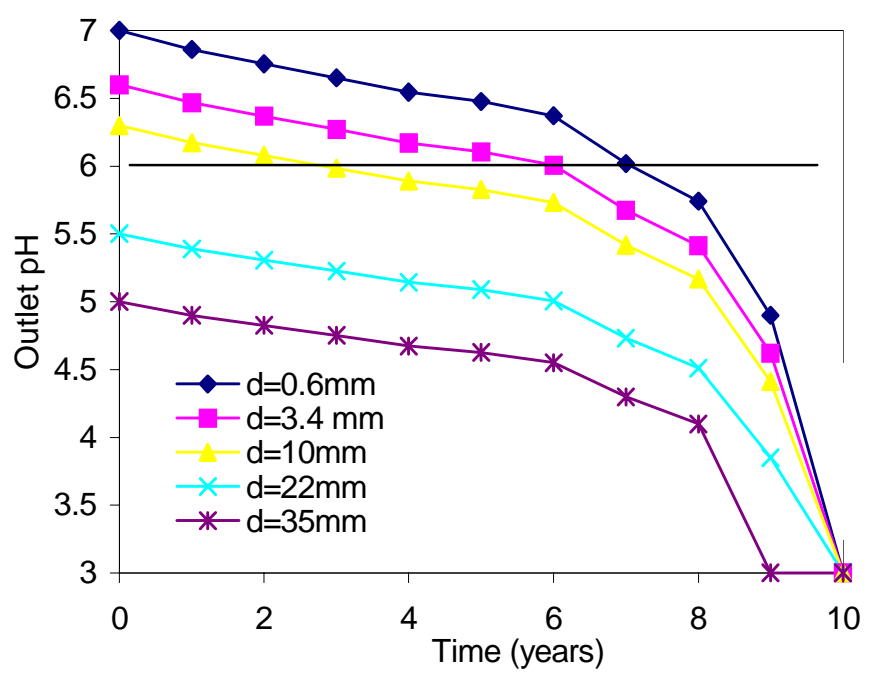

Figure 3.3. The outlet water quality changes with time at different particle size and an initial pH 3.

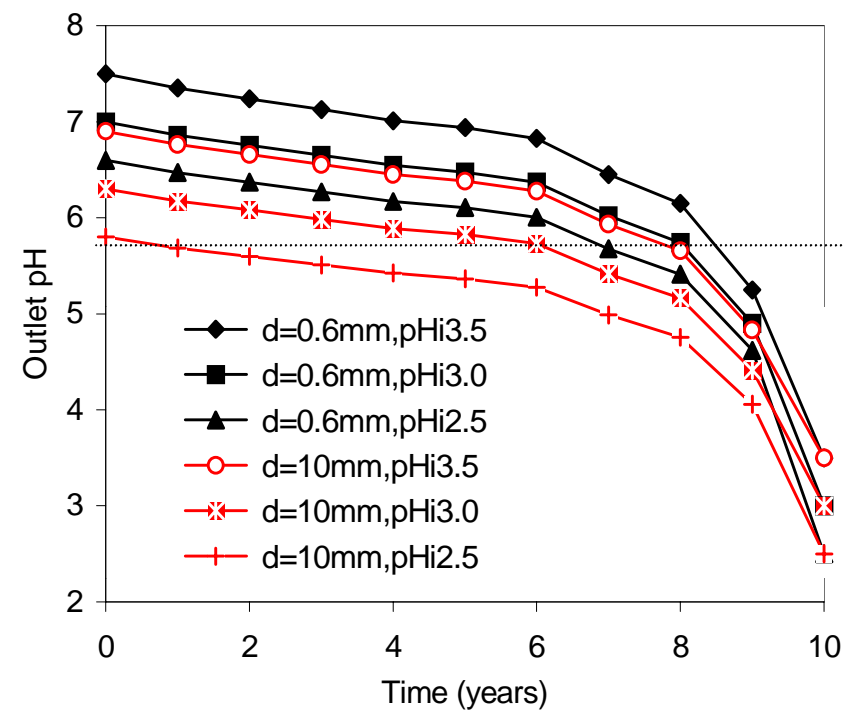

Figure 3.4. The outlet water quality changes with time at different initial $\mathrm{pH}$ value and optimal particle size $(\mathrm{d}=0.6 \mathrm{~mm})$ or larger particle size $(\mathrm{d}=10 \mathrm{~mm})$. 
Since AMD treatment systems must discharge water at $\mathrm{pH}>6$, the expected life of the optimized system would be 7 years. Note that this is less than the original calculated 10 years based only on limestone mass. The effect of larger particle size and lower influent $\mathrm{pH}$ on this system are given in Figures 3.3 and 3.4. If larger limestone particles (sieve size $10 \mathrm{~mm}$ ) are used in this example to build an open limestone channel, its effective lifetime for acid neutralization is about 4 years.

\section{Conclusion}

The neutralization of acid solutions by limestone is a surface-controlled reaction and limestone dissolution rate primarily depends on the limestone surface area and initial $\mathrm{pH}$ of the solution. Limestone particle size and shape determine the limestone mass specific surface area, which in turn affects limestone reaction surface in an open limestone treatment system. The required contact time between limestone and the acid solution is determined by the initial and final $\mathrm{pH}$ of the solution and the limestone

specific surface area, $t=a A_{M S}{ }^{k}$; where $\mathrm{k}$ and a are determined by the initial and final acidity of the acid solution.

These equations, incorporating reaction time, limestone surface area, and initial and final $\mathrm{pH}$, can be used to design an open limestone channel. If the initial $\mathrm{pH}$ and final $\mathrm{pH}$ of an AMD are known, the optimal limestone particle size and the dimensions of an open limestone channel can be selected. The effective life and the final $\mathrm{pH}$ of an open limestone channel can be predicted at any time from these equations. On the other hand, if we know the initial acidity of an acid mine drainage passing through an open limestone channel of specified length and particle size, the outlet water $\mathrm{pH}$ can be predicted based on the retention time. However, the economic factors of limestone size and amount should be considered when designing a limestone treatment system, as fine particles cost more to crush and prepare.

All these calculations and estimations can only be used for fresh open limestone channels. If a coating develops over limestone surfaces (like iron armoring), these equations should be corrected because the effective surface area changes. 


\section{References}

Allen, T. 1975. Particle Size Measurement. $2^{\text {nd }}$ Edition. John Wiley \&Sons, New York.

Berner, R. A., and J. W. Morse. 1974. Dissolution kinetics of calcium carbonate in sea water. American J. of Sci. 274:108-134.

Economou, E. D., N. P. Evmiridis, and A. G. Vlessidis. 1996. Dissolution kinetics of $\mathrm{CaCO}_{3}$ in powder form and influence of particle size and pretreatment on the course of dissolution. Ind. Eng. Chem. Res. 35:465-474.

Evangelou, V. P. 1998. Environmental Soil and Water Chemistry: Principles and Applications. Wiley, New York.

Garga, V.K., R. Townsend, and D. Hansen. 1991. A method for determining the surface area of quarried rocks. Geotech. Testing J. 14(1):35-45.

Maree, J. P., P. D. Plessis, and C. J. Van der Walt. 1992. Treatment of acidic effluents with limestone instead of lime. Wat. Sci. Tech. 26(1-2):345-355.

Pearson, F. H., and A. J. McDonnell. 1977. Characterization of coarse porous media. J. of the Environ. Eng. Division, ASCE. 103:615-624.

Sabin, G. C. W., and D. Hansen. 1994. The effects of particle shape and surface roughness on the hydraulic mean radius of a porous medium consisting of quarried rock. Geotech. Testing J. 17(1): 43-49.

Zurbuch, P. E. 1996. Early results from calcium carbonate neutralization of two West Virginia rivers acidified by mine drainage. p. L1-L9. In Proc. of the Seventeenth Annual West Virginia Surface Mine Drainage Task Force Symposium. Morgantown, WV. 


\section{Supporting Information}

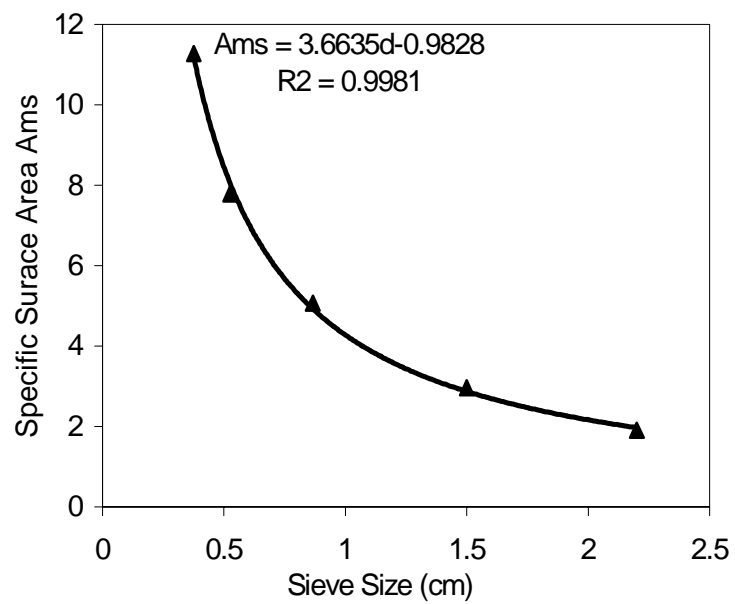

Figure 3.5. The specific surface area vs. the size of sieved limestone.

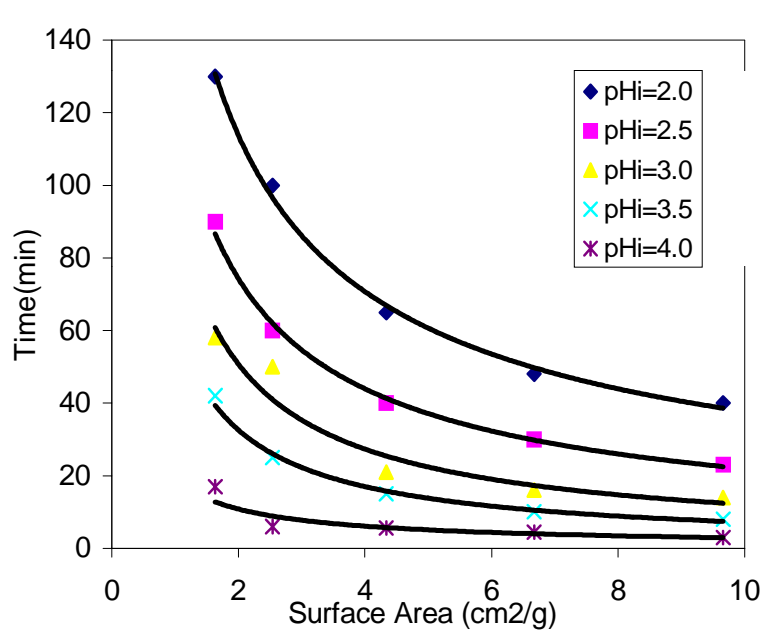

$$
\begin{array}{ll}
\mathrm{pH}_{\mathrm{i}} 2.0: \mathrm{t}=183.21 \mathrm{~A}_{\mathrm{MS}}{ }^{-0.6867} & \mathrm{R}^{2}=0.9952 \\
\mathrm{pH}_{\mathrm{i}} 2.5: \mathrm{t}=125.74 \mathrm{~A}_{\mathrm{MS}}{ }^{-0.7583} & \mathrm{R}^{2}=0.9965 \\
\mathrm{pH}_{\mathrm{i}} 2.0: \mathrm{t}=94.232 \mathrm{~A}_{\mathrm{MS}}{ }^{-0.8928} & \mathrm{R}^{2}=0.9432 \\
\mathrm{pH}_{\mathrm{i}} 2.0: \mathrm{t}=62.598 \mathrm{~A}_{\mathrm{MS}}{ }^{-0.9405} & \mathrm{R}^{2}=0.9911 \\
\mathrm{pH}_{\mathrm{i}} 2.0: \mathrm{t}=19.196 \mathrm{~A}_{\mathrm{MS}}{ }^{-0.8277} & \mathrm{R}^{2}=0.8484
\end{array}
$$

Figure 3.6. The reaction time required for various acid solutions (pHi 2.0 4.0) neutralized by different limestone surface areas to attain $\mathrm{pH}$ of 5.5. 


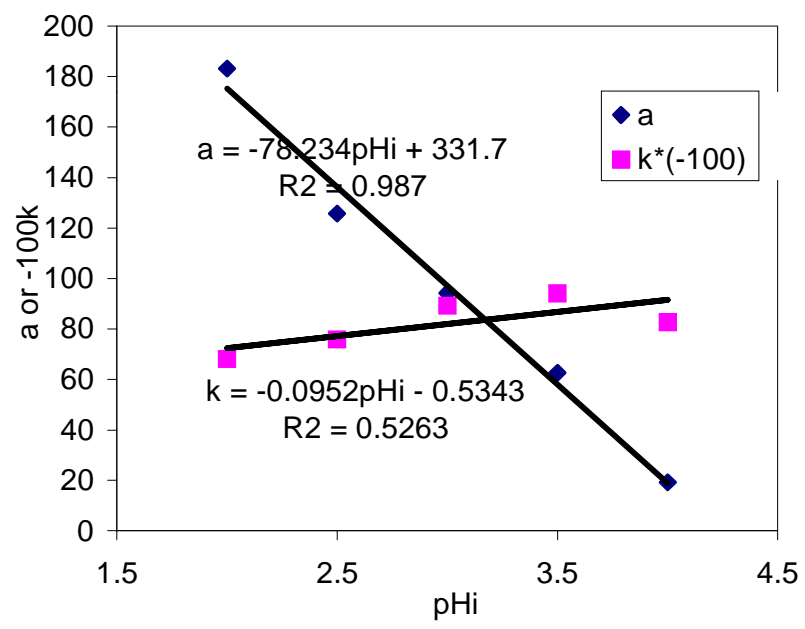

Figure 3.7. Reaction constant $\mathrm{k}$ and a vs. the initial $\mathrm{pH}$.

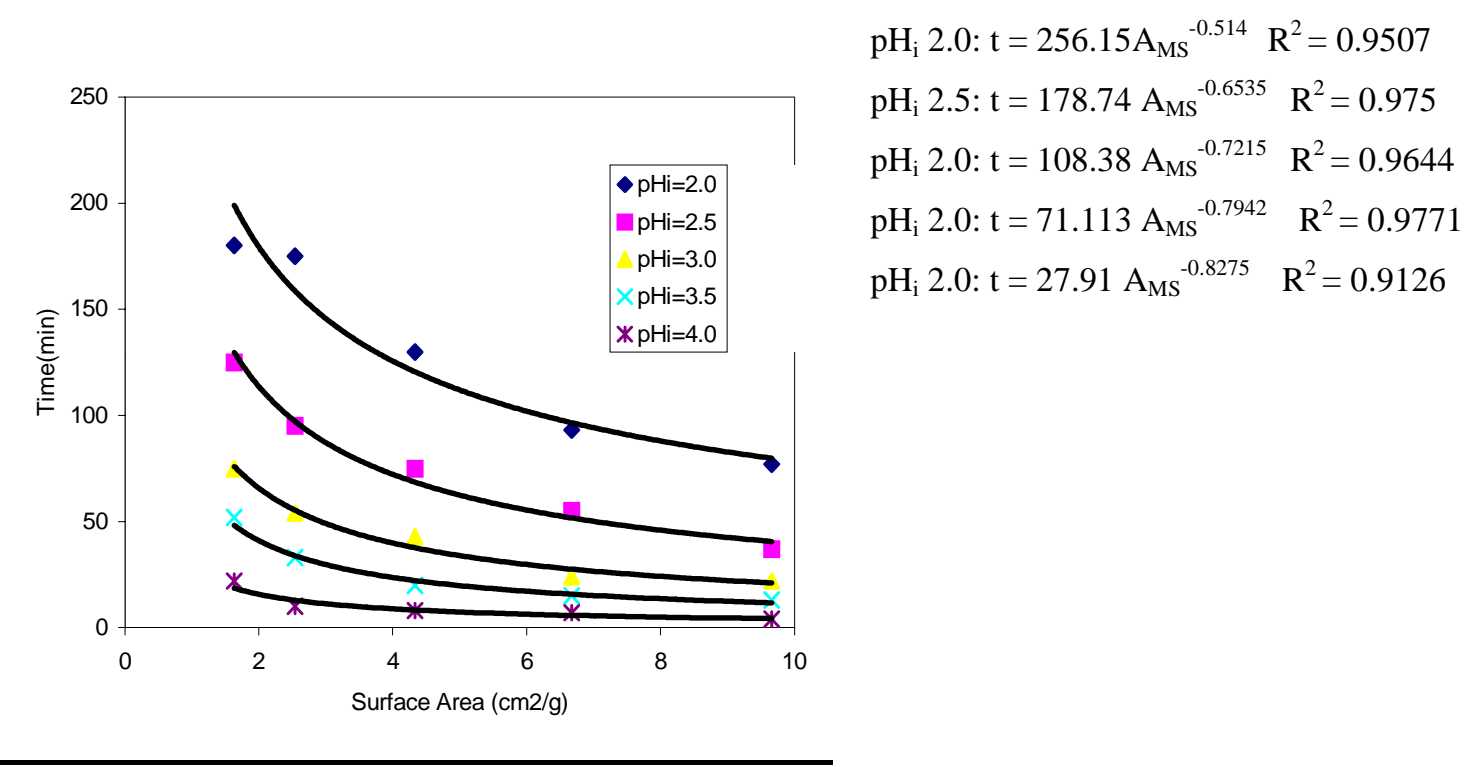

Figure 3.8. The reaction time required for various acid solutions (pHi 2.0 4.0) neutralized by different limestone surface areas to attain $\mathrm{pH}$ of 6.0. 


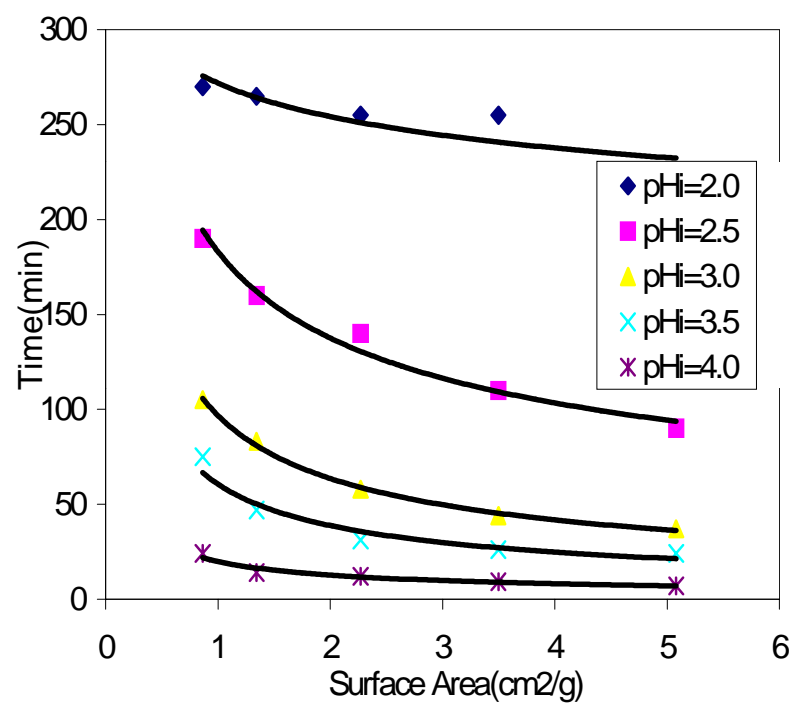

$\mathrm{pH}_{\mathrm{i}}$ 2.0: $\mathrm{t}=271.9 \mathrm{~A}_{\mathrm{MS}}{ }^{-0.097} \mathrm{R}^{2}=0.7345$

$\mathrm{pH}_{\mathrm{i}}$ 2.5: $\mathrm{t}=183.07 \mathrm{~A}_{\mathrm{MS}}{ }^{-0.4124} \mathrm{R}^{2}=0.9795$

$\mathrm{pH}_{\mathrm{i}}$ 2.0: $\mathrm{t}=96.723 \mathrm{~A}_{\mathrm{MS}}{ }^{-0.6063} \mathrm{R}^{2}=0.99969$

$\mathrm{pH}_{\mathrm{i}} 2.0: \mathrm{t}=60.552 \mathrm{~A}_{\mathrm{MS}}{ }^{-0.645} \mathrm{R}^{2}=0.9392$

$\mathrm{pH}_{\mathrm{i}} 2.0: \mathrm{t}=19.77 \mathrm{~A}_{\mathrm{MS}}{ }^{-0.6439} \quad \mathrm{R}^{2}=0.9569$

Figure 3.9. The reaction time required for various acid solutions (pHi 2.0 4.0) neutralized by different limestone surface areas to attain $\mathrm{pH}$ of 6.5 .

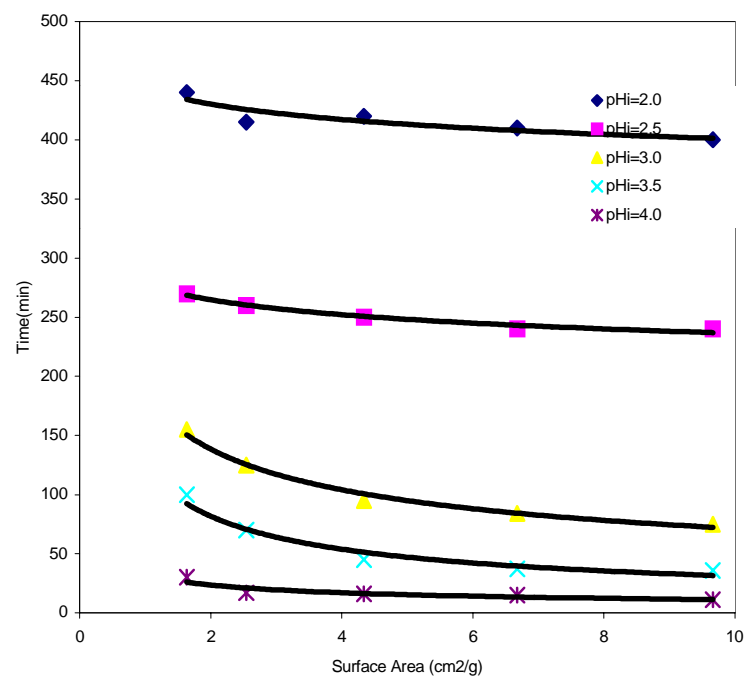

$$
\begin{aligned}
& \mathrm{pH}_{\mathrm{i}} 2.0: \mathrm{t}=443.62 \mathrm{~A}_{\mathrm{MS}}{ }^{-0.0442} \mathrm{R}^{2}=0.8047 \\
& \mathrm{pH}_{\mathrm{i}} 2.5: \mathrm{t}=278.06 \mathrm{~A}_{\mathrm{MS}}{ }^{-0.0705} \mathrm{R}^{2}=0.9642 \\
& \mathrm{pH}_{\mathrm{i}} 2.0: \mathrm{t}=184.21 \mathrm{~A}_{\mathrm{MS}}{ }^{-0.4119} \mathrm{R}^{2}=0.9843 \\
& \mathrm{pH}_{\mathrm{i}} 2.0: \mathrm{t}=123.93 \mathrm{~A}_{\mathrm{MS}}{ }^{-0.6014} \mathrm{R}^{2}=0.9431 \\
& \mathrm{pH}_{\mathrm{i}} 2.0: \mathrm{t}=32.569 \mathrm{~A}_{\mathrm{MS}}{ }^{-4682} \quad \mathrm{R}^{2}=0.8463
\end{aligned}
$$

Figure 3.10. The reaction time required for various acid solutions (pHi 2.0 4.0) neutralized by different limestone surface areas to attain $\mathrm{pH}$ of 7.0. 


\title{
Chapter 4. Iron Effects on Limestone Dissolution in Open Systems
}

\begin{abstract}
The chemical composition and metal concentrations of acid solutions have a significant influence on limestone dissolution rate. Metals, like iron, in water can be neutralized by limestone, but the limestone surface may be coated, thereby limiting its surface area for reaction. This study reports the relationships between limestone neutralization of acid solutions containing iron and without iron in order to set up empirical limestone neutralization models. In open air systems, the required reaction time (t) for a proton-only acid solution to be neutralized to a destination $\mathrm{pH}$ is predicted by $t=a A_{M S}{ }^{k}$, where $\mathrm{t}$ is the function of initial $\mathrm{pH}$, final $\mathrm{pH}$ and limestone mass-specific surface area. However, the batch experiments showed that the neutralization reactions with iron-containing water required more time. The required reaction times were modified with the function, $t(F e)=t(F e=0)+(42 \ln [F e]+35.1) p H_{f}-176 \ln [F e]-143$, where $\mathrm{t}(\mathrm{Fe})$ is the required reaction time for iron acid solution; $\mathrm{t}(\mathrm{Fe}=0)$ is the reaction time for proton-only acid solutions, $[\mathrm{Fe}]$ is iron concentration, and $\mathrm{pH}_{\mathrm{f}}$ is the final $\mathrm{pH}$. In addition, the limestone requirement to neutralize iron acid solutions is calculated by $[\mathrm{Ca}]_{\mathrm{Fe}}=0.309 \mathrm{C}_{\mathrm{T}}+0.27\left[\mathrm{Fe}^{3+}\right]_{\mathrm{i}}+0.448$, where $[\mathrm{Ca}]_{\mathrm{Fe}}$ is total dissolved $\mathrm{Ca}$ in $\mathrm{mmol} / \mathrm{L}$, $\mathrm{C}_{\mathrm{T}}$ is total initial acidity (meq/L), and $\left[\mathrm{Fe}^{3+}\right]_{\mathrm{i}}$ is initial iron concentration (mmol/L).
\end{abstract}




\section{Introduction}

Limestone neutralization of acid solutions in an open-air system may be summarized by the following Equations 1 and 2. Each plays a different role during the neutralization process, which is mainly controlled by acidity (or $\mathrm{pH}$ ), limestone surface area, temperature, ionic strength, and ion species and concentration.

$$
\begin{aligned}
& \mathrm{CaCO}_{3}+\mathrm{H}^{+} \Leftrightarrow \mathrm{Ca}^{2+}+\mathrm{HCO}_{3}^{-} \\
& \mathrm{CaCO}_{3}+2 \mathrm{H}^{+} \Leftrightarrow \mathrm{Ca}^{2+}+\mathrm{H}_{2} \mathrm{O}+\mathrm{CO}_{2} \uparrow
\end{aligned}
$$

When the solution has low $\mathrm{pH}$, almost all the dissolved $\mathrm{CO}_{3}{ }^{2-}$ forms $\mathrm{H}_{2} \mathrm{CO}_{3}$, which may quickly change into $\mathrm{CO}_{2}$ gas and be released from solution. During this period, Equation 2 dominates limestone dissolution. As $\mathrm{pH}$ rises, $\mathrm{CO}_{3}{ }^{2-}$ begins to form $\mathrm{HCO}_{3}{ }^{-}$and $\mathrm{CO}_{2}$ gas is released less and less. At high $\mathrm{pH}$, Equation 1 becomes dominant where almost no $\mathrm{CO}_{2}$ gas is released.

Limestone dissolution is a solid-liquid reaction, so many factors, such as diffusion, temperature, ionic strength, and $\mathrm{CO}_{2}$ partial pressure may affect its reaction. The ion species and their activities effects on the dissolution of $\mathrm{CaCO}_{3}$ were presented by the net dissolution rate (Plummer and Wigley, 1978):

$$
R=k_{1} \alpha_{\mathrm{H}^{+}}+k_{2} \alpha_{\mathrm{H}_{2} \mathrm{CO}_{3}}+k_{3} \alpha_{\mathrm{H}_{2} \mathrm{O}}-k_{4} \alpha_{\mathrm{Ca}^{2+}} \alpha_{\mathrm{HCO}_{3}^{-}}
$$

where $\mathrm{R}$ is net dissolution rate, $\mathrm{k}_{1}, \mathrm{k}_{2}$ and $\mathrm{k}_{3}$ are first order rate constants, $\mathrm{k}_{4}$ is the function of temperature and $\mathrm{P}_{\mathrm{CO} 2}, \alpha_{\mathrm{H}^{+}}, \alpha_{\mathrm{Ca}^{2+}}, \alpha_{\mathrm{H}_{2} \mathrm{CO}_{3}}, \alpha_{\mathrm{H}_{2} \mathrm{O}}$, and $\alpha_{\mathrm{HCO}_{3}^{-}}$are activities of species.

Dissolved metals have significant influences on limestone neutralization of acid solutions, and dissolved aluminum and iron may increase acidity of AMD (Broshears et al., 1996). Iron is the most common dissolved metal in AMD. Acid solutions containing 
iron consume more limestone than proton acid solutions because of iron hydrolysis and precipitation (Eq. 4 or 5).

$$
\begin{aligned}
& \mathrm{Fe}^{3+}+3 \mathrm{H}_{2} \mathrm{O} \longleftrightarrow \mathrm{Fe}(\mathrm{OH})_{3(\mathrm{~s})}+3 \mathrm{H}^{+} \\
& \mathrm{Fe}^{3+}+2 \mathrm{H}_{2} \mathrm{O} \longleftrightarrow \mathrm{FeOOH}+3 \mathrm{H}^{+}
\end{aligned}
$$

Iron hydrolysis reactions are $\mathrm{pH}$ buffered near $\mathrm{pH}$ 3.5. Therefore, the concentrations of ferric ion in acid solutions may affect limestone dissolution rate as well as the increase of $\mathrm{pH}$ with neutralizing time. Loeppert et al. (1984) showed iron effects on the neutralization of acid solutions. Solution $\mathrm{pH}$ decreased slightly initially due to iron hydrolysis and then gradually increased to its equilibrium during the neutralization of iron acid solutions by limestone.

Iron not only increases the acidity of solutions and neutralization time, but it also can armor the surface of limestone. Once limestone is coated with iron hydroxides, limestone dissolution rate decreases from $20 \%$ to $90 \%$ of its fresh uncoated state (Pearson and McDonnell, 1977; Ziemkiewicz et al., 1994). Thus, the neutralization of iron acid solutions by limestone will require more reaction time due to iron effects on reaction surfaces and reaction rate.

The objective of this study was to model the neutralization of iron acid solutions by limestone particles. By comparing the neutralization of proton acid solutions with iron acid solutions, the interactions among acid levels, limestone particle sizes, and iron concentration were quantitatively accounted for. The desired equation will allow more accurate limestone requirements to neutralize iron containing acid solutions. This will help design of limestone amount and particle sizes for the treatment of AMD containing iron in open limestone systems

\section{Materials and Methods}

All limestone for our laboratory experiments came from Germany Valley, West Virginia, which has $\mathrm{a} \mathrm{CaCO}_{3}$ equivalent of 98.5\% (Zurbuch, 1996). Crushed limestone 
was prepared by crushing separate samples of limestone with a Jaw Crusher and sieving into the same size classes $(6-11 \mathrm{~mm})$. Flat, square limestone blocks $(38$ x 38 x $8 \mathrm{~mm})$ were prepared by cutting large blocks of limestone with a rock saw. A single $35 \times 35 \mathrm{~mm}$ surface was isolated by dipping the block in liquid Saran and drying at $105^{\circ} \mathrm{C}$.

Batch experiments were designed to use $100 \mathrm{~g}$ of the crushed limestone chips or eight pieces of square limestone blocks to neutralize $400 \mathrm{~mL}$ of the stirred acid solution with iron and without iron in a $600-\mathrm{mL}$ beaker. A series of ferric acid solutions $(\mathrm{pH}$ ranged between 2.0 and 3.0) were made with $\mathrm{FeCl}_{3} * 6 \mathrm{H}_{2} \mathrm{O}$ and de-ionized water. The $\mathrm{pH}$, calcium, and iron concentrations were measured over time as the neutralization experiments progressed. At each time interval, a 0.9-ml sample was taken, filtered with a $0.45-\mu \mathrm{m}$ syringe-operated filter (Millipore), and diluted with $4.1 \mathrm{ml}$ of $2 \% \mathrm{HNO}_{3}$. These acidified samples were analyzed for $\mathrm{Ca}$ and $\mathrm{Fe}$ concentrations with either Inductively Coupled Plasma (Perkin Elmer P4000) or Atomic Absorption Spectroscopy (Perkin Elmer 5000). The $\mathrm{pH}$ of the solution was measured by an Accumet $\mathrm{pH}$ meter 25 (Fisher Scientific Company, Accu-pHast Electrode).

\section{Results and Discussion}

During the neutralization of iron acid solutions, the increase of $\mathrm{pH}$ led ferric ion to form iron hydroxides and precipitate from solution. Since iron hydrolysis and complexation occur simultaneously, it is impossible to separate iron hydroxide formation from hydrolysis or limestone neutralization. Thus, the results show that total iron concentration changes with time (Figure 4.1). The total iron concentration in the solution remained unchanged during an initial period but then suddenly declined rapidly, where iron precipitation time depended on the initial iron concentrations and $\mathrm{pH}$. 


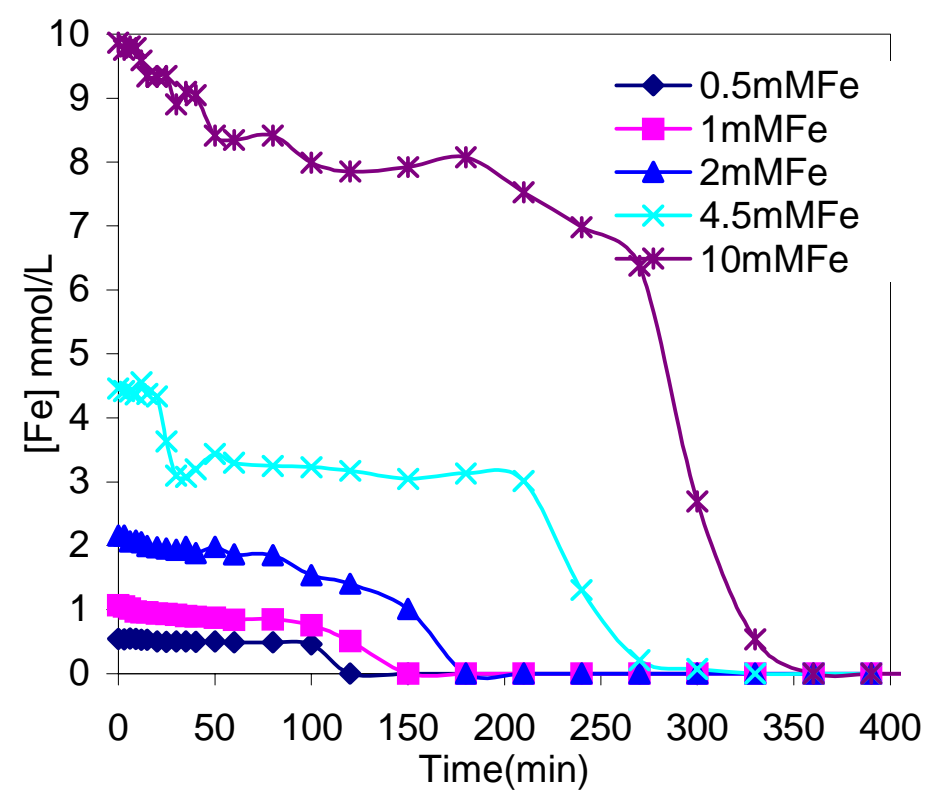

Figure 4.1. Fe concentration of various iron solutions being neutralized by limestone.

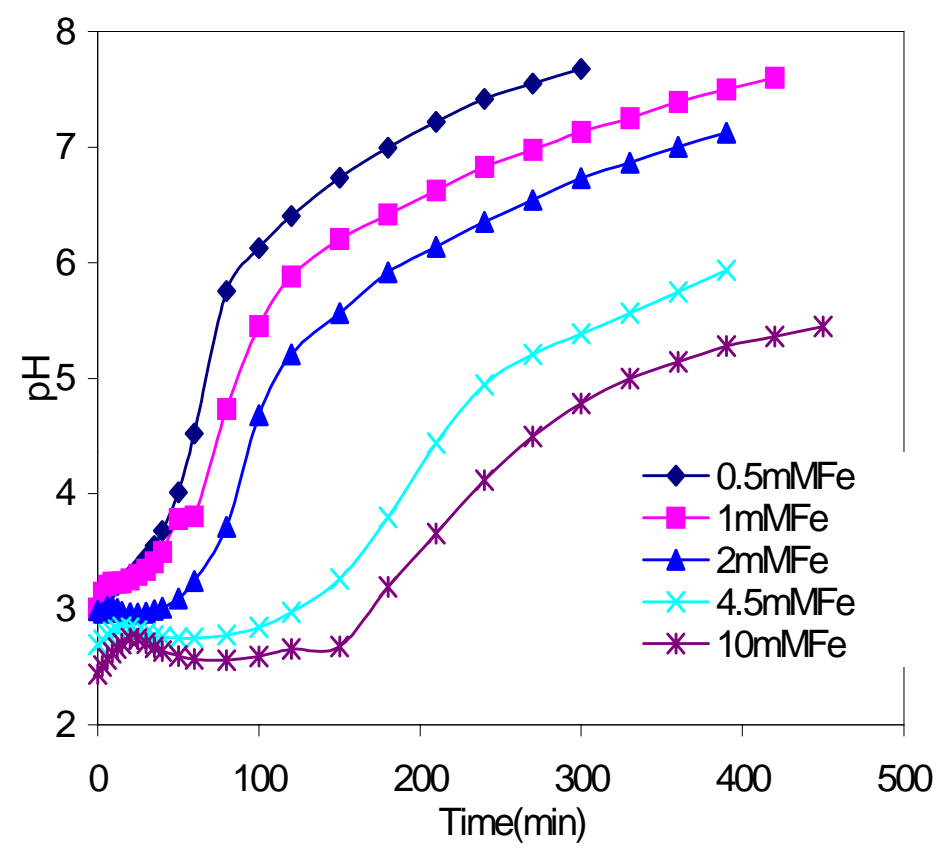

Figure 4.2. pH vs. time in iron acid solutions. 


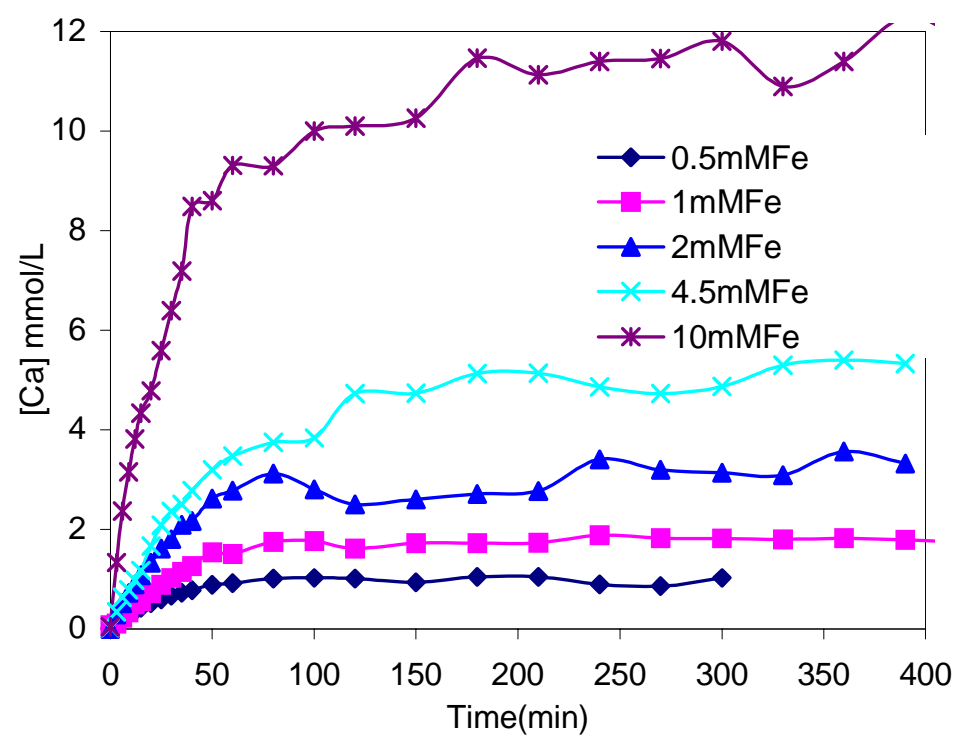

Figure 4.3. Dissolved Ca vs. time in iron acid solution.

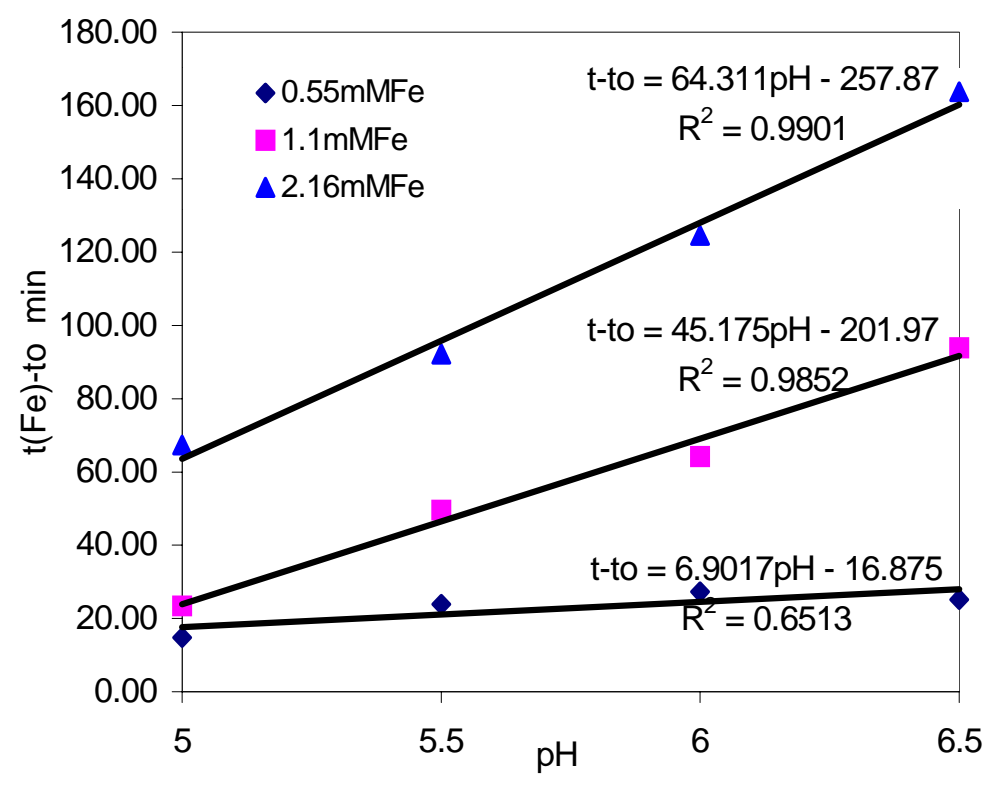

Figure 4.4. The reaction time difference of $\mathrm{pH}$ reaching 5.5, 6.0 and 6.5 vs. ferric concentration by $6.3-11 \mathrm{~mm}$ ellipsoid limestone.

The results of $\mathrm{pH}$ changing with time in iron acid solutions presented different trends from proton acid solutions (Figure 4.2). During the neutralization of proton acid 
solutions, $\mathrm{pH}$ increases continually with time until reaching the equilibrium. In iron acid solutions, $\mathrm{pH}$ increase was caused by limestone dissolution during the first 10-20 minutes. Then, $\mathrm{pH}$ began decreasing but limestone was still dissolving (Figure 4.3). The length of this period depended on the iron concentration. The higher the iron concentration, the longer the period and the lower the $\mathrm{pH}$ went. These buffering processes were caused by iron hydroxide. After these lag periods with decreasing $\mathrm{pH}, \mathrm{pH}$ began increasing again until its equilibrium. Thus, the required reaction time of $\mathrm{pH}$ increasing to a final $\mathrm{pH}$ should be corrected for iron concentration.

The experimental data (Figure 4.4) showed that a linear relationship existed between the required time for neutralization of iron acid solutions and hydrogen acid solutions with identical initial $\mathrm{pH}$ as Equation 6.

$$
\begin{aligned}
& \Delta t=t(F e)-t(F e=0)=(42 \ln [F e]+35.1) p H_{f}-176 \ln [F e]-143 \\
& t(F e)=t(F e=0)+(42 \ln [F e]+35.1) p H_{f}-176 \ln [F e]-143
\end{aligned}
$$

where $\Delta \mathrm{t}$ is the difference of the retention time between iron acid solution neutralization, $t(F e)$ is the required reaction time for iron acid solutions, $t(F e=0)$ is reaction time for hydrogen acid neutralization, and $\mathrm{pH}_{\mathrm{f}}$ is the final outlet $\mathrm{pH}$.

According to the previous derived equations $t=a A_{M S}{ }^{k}$ (Chapter 3, Eq. 12) for hydrogen acid solution neutralization, the required reaction time for iron acid solutions to be neutralized to a certain specified $\mathrm{pH}$ is:

$$
t(F e=0)=\left[\left(-75.08 p H_{f}+338.27\right) p H_{i}+0.8053 p H_{f}^{3.5346}\right] A_{M S}{ }^{\left(-0.1305 p H_{f}+0.6185\right) p H i+\left(0.7365 p H_{f}-4.5918\right)}
$$

So, the required reaction time that limestone particles with a mass specific surface area to neutralize iron acid solutions to a final $\mathrm{pH}$ is: 


$$
\begin{aligned}
& \mathrm{t}(\mathrm{Fe})=\left[\left(-75.08 p H_{f}+338.27\right) p H_{i}+0.8053 p H_{f}^{3.5346}\right] A_{M S}{ }^{\left(-0.1305 p H_{f}+0.6185\right) p H i+\left(0.7365 p H_{f}-4.5918\right)} \\
& \quad+(42 \ln [\mathrm{Fe}]+35.1) p H_{f}-176 \ln [\mathrm{Fe}]-143
\end{aligned}
$$

where $\mathrm{pH}_{\mathrm{f}}$ is the final outlet $\mathrm{pH}, \mathrm{t}$ is the required reaction time (min), $\mathrm{pHi}$ is initial $\mathrm{pH}$ of the acid solution, $A_{M S}$ is the mass specific surface area of limestone particles, and $[\mathrm{Fe}]$ is ferric iron concentration of the acid solution ( $\mathrm{mmol} / \mathrm{L})$.

Iron hydrolysis and precipitation generated more hydrogen, so iron acid solutions need more time to neutralize the acidity. Generally speaking, higher iron concentration causes an increase in limestone dissolution due to the increase of hydrogen acid from iron hydrolysis and precipitation. The presence of iron makes limestone dissolution more complicated, so the limestone dissolution can be derived from the total dissolved calcium concentration (Figure 4.3).

With limestone neutralization of acid solutions without iron, the total dissolved $\mathrm{Ca}$ should relate linearly to the total initial acidity of a solution. The total acidity of iron acid solutions (Table 4.1) was calculated by Equation 10.

$$
\mathrm{C}_{\mathrm{T}}=\left[H^{+}\right]+3\left[\mathrm{Fe}^{3+}\right]
$$

Where $\mathrm{C}_{\mathrm{T}}$ is total acidity (meq/L); $\left[\mathrm{H}^{+}\right]$is initial hydrogen concentration $(\mathrm{mmol} / \mathrm{L})$; and $\left[\mathrm{Fe}^{3+}\right]$ is ferric ion concentration $(\mathrm{mmol} / \mathrm{L})$. A plot of the total dissolved calcium concentration vs. the total acidity shows the difference between the required limestone for proton acid solution and iron acid solutions (Figure 4.5).

Table 4.1. Calculation of total acidity of five iron solutions with $\mathrm{pH}$ between 2.4 and 3.0.

\begin{tabular}{ccccc}
\hline $\mathrm{pH}_{\mathrm{i}}$ & {$\left[\mathrm{H}^{+}\right]_{\mathrm{i}}$} & {$[\mathrm{Fe}]_{\mathrm{i}}$} & {$[\mathrm{Ca}]$ Final } & $\mathrm{C}_{\mathrm{T}}$ \\
\hline & --------- & $\mathrm{mmol} / \mathrm{L}$ & -------- & $\mathrm{meq} / \mathrm{L}$ \\
3.00 & 1.00 & 0 & 0.96 & 1.00 \\
2.97 & 1.06 & 0.55 & 1.42 & 2.70 \\
3.01 & 0.99 & 1.07 & 1.82 & 4.19 \\
2.99 & 1.03 & 2.16 & 3.56 & 7.50 \\
2.70 & 2.02 & 4.46 & 6.10 & 15.40 \\
2.44 & 3.64 & 9.87 & 13.50 & 33.25 \\
\hline
\end{tabular}




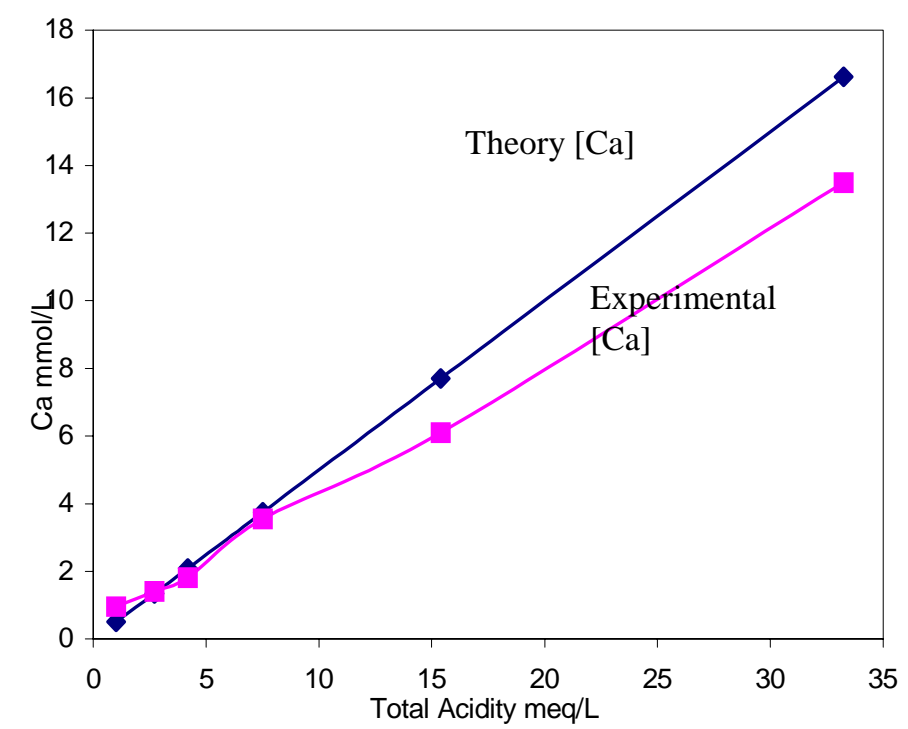

Figure 4.5. Dissolved Ca concentrations vs. the acidity in solutions with and without iron.

The experimental data revealed that the concentration of dissolved calcium at equilibrium is lower than the theoretical value (Figure 4.5), where one mole limestone can neutralize two equivalents of acidity. The total dissolved $\mathrm{Ca}$ is the function of initial iron concentration and total acidity as Equation 12.

$$
[\mathrm{Ca}]_{\mathrm{Fe}}=0.309 \mathrm{C}_{\mathrm{T}}+0.27\left[\mathrm{Fe}^{3+}\right]_{i}+0.448
$$

where $[\mathrm{Ca}]_{\mathrm{Fe}}$ is total dissolved $\mathrm{Ca}$ in $\mathrm{mmol} / \mathrm{L} ; \mathrm{C}_{\mathrm{T}}$ is total initial acidity (meq/L); and $\left[\mathrm{Fe}^{3+}\right]_{\mathrm{i}}$ is initial ferric ion concentration $(\mathrm{mmol} / \mathrm{L})$.

Thus, more limestone is required to neutralize the same amount of acidity in hydrogen acid solutions than iron acid solutions. One reason for iron acid solutions consuming less limestone may be that some iron forms complexes, which may be absorbed to the surfaces of $\mathrm{Fe}(\mathrm{OH})_{3}$ or co-precipitate with iron hydroxides, thereby reducing the total alkalinity needed for neutralization. In addition, ionic strength effects may decrease the limestone amount needed for neutralization. 


\section{Example}

To show how iron affects a limestone treatment system, the following example is given.

Suppose an acid mine drainage source has $1000 \mathrm{~L} / \mathrm{min}$ of flow and the water has an initial $\mathrm{pH}$ of 3.0 (acidity $10^{-3} \mathrm{M}$ or $50 \mathrm{mg} / \mathrm{L}$ as $\mathrm{CaCO}_{3}$ ), but also contains $55 \mathrm{mg} / \mathrm{L}$ of iron. If the outlet $\mathrm{pH}$ is specified to be 7.0 and the open limestone channel is designed for 10 years, the retention time based on an optimal limestone particle size $(\mathrm{d}=10 \mathrm{~mm}$ for hydrogen acid solution) should be increased and limestone requirement should increase due to the increased iron acidity concentration.

Inflow:
$\mathrm{pH}_{\text {initial }}=3.0$
$[\mathrm{Fe}]=55 \mathrm{mg} / \mathrm{L}$
Flow rate:
$\mathrm{Q}=1000 \mathrm{~L} / \mathrm{min}$

Theoretical limestone

$$
\begin{aligned}
& \text { requirement: } 1,051,200 \mathrm{~kg} \text { Outflow: } \\
& \mathrm{pH}_{\text {final }}=7.0 \\
& {[\mathrm{Fe}]=0} \\
& \text { Initial optimal retention } \\
& \text { time } \mathrm{t}=60 \mathrm{~min}
\end{aligned}
$$

According to previous optimal calculation based on hydrogen acid (pH 3.0 without iron), the optimal limestone size is about $10 \mathrm{~mm}$ and the lifetime is about 5 years.

Considering the effect of iron, the acid load is:

$$
\mathrm{A}=\left(10^{-p H_{0}}+3[\mathrm{Fe}] / 55 / 1000\right) Q^{*} 365 * 24 * 60 * 50=105,120,000 \mathrm{~g} \mathrm{CaCO}_{3} / \text { year. }
$$

Theoretical amount of limestone required for 10 years is:

$$
\mathrm{W}=10 * \mathrm{~A}=1,051,200 \mathrm{~kg} \mathrm{CaCO}_{3} / \text { year }
$$

The real limestone required for 10 years is:

$$
\begin{aligned}
\mathrm{W}_{0} & =10 *\left(0.309 \mathrm{C}_{\mathrm{T}}+0.27\left[\mathrm{Fe}^{3+}\right]_{\mathrm{i}}+0.448\right) \mathrm{Q} * 365 * 24 * 60 * 50 * 100 \\
& =1,027,022,400 \mathrm{~g}=1,027,022.4 \mathrm{~kg}
\end{aligned}
$$

To make the outlet $\mathrm{pH} 7.0$, the retention time should be:

$$
\begin{aligned}
\mathrm{t}= & {\left[\left(-75.08 p H_{f}+338.27\right) p H_{i}+0.8053 p H_{f}^{3.5346}\right] A_{M S}{ }^{\left(-0.1305 p H_{f}+0.6185\right) p H i+\left(0.7365 p H_{f}-4.5918\right)} } \\
& +(42 \ln [\mathrm{Fe}]+35.1) p H_{f}-176 \ln [\mathrm{Fe}]-143=245 \mathrm{~min}
\end{aligned}
$$

If the reaction time is only 60 minutes, the outlet water $\mathrm{pH}$ can be estimated to be 4.95 . 


\section{Conclusion}

Iron in acid solution has significant influences on limestone dissolution, and iron removal by precipitation depends on initial iron concentration and $\mathrm{pH}$ of the solutions. Neutralization of iron acid solutions is different from that of hydrogen acid solutions. There is a lag period (in fact a slight decrease) for $\mathrm{pH}$ that gradually increases with time as the neutralization of iron acid solutions continues, so it may need more reaction time to reach a final $\mathrm{pH}$. The previous model to predict the reaction time needed for proton acid solutions to be neutralized by limestone should be corrected for iron concentration. Iron effects on required reaction time for acid to be neutralized are a function of the final $\mathrm{pH}$ and iron concentrations, $t(F e)=t(F e=0)+(42 \ln [F e]+35.1) p H_{f}-176 \ln [F e]-143$. Therefore, the retention time needed for neutralization can be corrected by including a term for initial iron concentration. Thus, once the initial $\mathrm{pH}$ and iron concentration are known and the final $\mathrm{pH}$ is specified, the surface area and residence time can be estimated.

The amount of limestone needed to neutralize the acidity of iron solutions is less than the amount need for the same acidity of hydrogen solutions due to iron coprecipitation and complex such as $\mathrm{Fe}(\mathrm{OH})^{+2}$ and $\mathrm{Fe}(\mathrm{OH})_{2}{ }^{+}$, being precipitated with $\mathrm{Fe}(\mathrm{OH})_{3}$. Therefore, when iron concentration is high, the limestone requirement may be less than the theoretical amount calculated by the acid load.

\section{References}

Broshears, R. E., R.L. Runkel, E. A. Kimball, D. M. Mcknight, and K. E. Bencala. 1996. Reactive solute transport in an acid stream: experimental $\mathrm{pH}$ increase and simulation of controls on pH, aluminum, and iron. Environ. Sci. \& Tech. 30(10):3016-3024.

Loeppert, R. H., L. R. Hossner, and P. K. Amin. 1984. Formation of ferric oxyhydroxides from ferrous and ferric perchlorate in stirred calcareous systems. Soil Sci. Soc. Am. J. 48:677-683. 
Pearson, F. H. and A. J. McDonnell. 1977. Characterization of coarse porous media. J. of the Environ. Eng. Division, ASCE. 103: 615-624.

Plummer, L. N. and T. M. L. Wigley. 1978, The kinetics of calcite dissolution in $\mathrm{CO}_{2^{-}}$ water systems at $5^{\circ}$ to $60^{\circ}$ and 0 to 1.0 atm $\mathrm{CO}_{2}$. Am. J. of Sci. 278:179-216.

Ziemkiewicz, P.F., J.G. Skousen, and R. Lovett. 1994. Open limestone channels for treating acid mine drainage: a new look at an old idea. Green Lands 24(4):36-41.

Zurbuch, P. E. 1996. Early results from calcium carbonate neutralization of two West Virginia rivers acidified by mine drainage. p. L1-L9. In Proc. of the Seventeenth Annual West Virginia Surface Mine Drainage Task Force Symposium. Morgantown, WV. 


\title{
Chapter 5. Coating Effects on Limestone Dissolution
}

\begin{abstract}
The use of limestone in treating AMD is limited because metals, particularly iron, develop a coating, thereby armoring the limestone surface and inhibiting its dissolution. Previous studies have shown that coated limestone does not completely stop dissolving, but its dissolution can be slowed from $20 \%$ to $90 \%$ of uncoated limestone. This study evaluated the thickness of the coating materials, and examined the effect of these factors on limestone dissolution rates. Electron photomicrographs showed the effects of moisture and iron concentration on the coating formation. Differences in drying methods influenced the number and depth of cracks in the coating. The composition of the coatings did not vary with iron concentration, and X-ray diffraction patterns revealed that the coatings were primarily composed of iron hydroxides and calcium sulfates. The thicker coatings reduced the limestone neutralization rate. Comparing the neutralization of acid solutions by limestone with different coating thicknesses, we developed a general function, $\mathrm{t}=\mathrm{f}\left(\mathrm{pH}_{\mathrm{i}}, \mathrm{pH}_{\mathrm{f}},\left[\mathrm{Fe}^{3+}\right], \mathrm{A}_{\mathrm{MS}}, \eta\right)$, to predict the treatment of AMD containing iron in armored limestone treatment systems, where $\mathrm{t}$ is required reaction time $(\mathrm{min}) ; \mathrm{pH}_{\mathrm{f}}$ is the final outlet $\mathrm{pH} ; \mathrm{pH}_{\mathrm{i}}$ is initial $\mathrm{pH}$ of acid solution; $\mathrm{A}_{\mathrm{MS}}$ is specific surface area of limestone particles; $\left[\mathrm{Fe}^{3+}\right]$ is ferric iron concentration of the acid solution $(\mathrm{mmol} / \mathrm{L})$; and $\eta$ is the coefficient representing coating effects on limestone dissolution.
\end{abstract}




\section{Introduction}

Open limestone channels or ditches introduce alkalinity to acid water (Ziemkiewicz et al., 1997). Where metals such as iron are dissolved in the water, a coating forms on the limestone surface. Initial assumptions held that armored limestone (limestone covered or coated with Fe or Al hydroxides) did not dissolve. However, Pearson and McDonnell (1977) showed that coated limestone continues to dissolve at about $20 \%$ of the rates of unarmored limestone. Recent work has demonstrated that the dissolution rate for armored limestone may be even higher than the 20\% (Ziemkiewicz et al., 1997), but continued dissolution likely depends on solution $\mathrm{pH}$, thickness of the coating, and other variables. Field experiments have shown that the length of the channel and the channel gradient, which affect turbulence and the buildup of coatings, are design factors that can be varied for optimum performance (Ziemkiewicz et al., 1994). Optimum performance was attained on slopes exceeding $20 \%$, where flow velocities kept precipitates in suspension and clean precipitates from limestone surfaces during high flow events containing high amounts of sediment (Ziemkiewicz et al., 1994).

The acidity (or $\mathrm{pH}$ ) of the solution, limestone surface area, and metal ions are primary factors that affect the neutralization rate of acid solutions. Surface area and calcium concentration effects on the limestone dissolution were presented by the first order reaction rate (Maree et al., 1992), where reaction rate is linearly related to the surface area of limestone. The initial $\mathrm{pH}$ and iron concentration of an acid solution also have direct influences on the neutralization of acid solutions, so reaction time for fresh limestone to neutralize acid solutions will vary with initial $\mathrm{pH}$, iron concentration, and limestone surface area in the following manner (Chapter 4):

$$
\mathrm{t}=a A_{M S}{ }^{k}+(42 \ln [F e]+35.1) p H_{f}-176 \ln [F e]-143
$$

Where $t$ is the time for acid solutions to be neutralized to a designed final $\mathrm{pH}, \mathrm{A}_{\mathrm{MS}}$ is limestone mass specific surface area, a and $\mathrm{k}$ are surface and $\mathrm{pH}$ effect constants, $[\mathrm{Fe}]$ is iron concentration, and $\mathrm{pH}_{\mathrm{f}}$ is the final $\mathrm{pH}$. 
The generation of coating materials on limestone surfaces primarily results from metal hydroxide precipitation. In eastern U.S. coal mining areas, most coating material is composed of ferric hydroxides since iron is the most common metal in AMD. In open air systems, iron exists primarily as the oxidized ferric iron, and limestone neutralization results in the formation of ferric hydroxide. When limestone neutralizes AMD containing both ferric and ferrous ions, many iron compounds can exist and co-precipitation can occur. Under such conditions, the ferrous iron may be oxidized to ferric iron in acid solution (Sung, 1981).

The suspended neutralized iron compounds, as fine solid particles, may absorb onto limestone surfaces to form layers of iron hydroxide (Christiansen and Nielson, 1951). The coating crystal growth rate can be expressed as (Snoeyink and Jenkins, 1980):

$$
\frac{d C}{d t}=-k S\left(C-C^{*}\right)^{n}
$$

Where $\mathrm{C}$ and $\mathrm{C}^{*}$ are actual and saturation concentrations, $\mathrm{k}$ is a rate constant, $\mathrm{S}$ is surface area available for precipitation, and $\mathrm{n}$ is a constant. In the $\mathrm{Fe}\left(\mathrm{ClO}_{4}\right)_{3}$ system, Loeppert et al. (1984) found that crystalline iron oxides partially coated the calcite surface, and simple iron species subsequently precipitated on existing $\mathrm{FeOOH}$ nuclei on the limestone surface.

Because of the complicated mineral composition, X-ray diffraction was introduced to study coating mineral structure. Loeppert and Hossner (1984) found that lepidocrocite $(\gamma \mathrm{FeO}-\mathrm{OH})$ and goethite $(\alpha \mathrm{FeO}-\mathrm{OH})$ dominated the iron coating of limestone with a ferrous iron system, while poorly crystalline ferrihydrite (FeO-OH) was the only product in ferric systems. X-ray diffraction analysis showed the mineral's formation that is dependent on the $\mathrm{pH}$ values of the solutions (Schwertmann and Murad, 1983), where ferrihydrite resulted in the formation of goethite and hematite $\left(\mathrm{Fe}_{2} \mathrm{O}_{3}\right)$.

While some research has been done on iron hydroxide formation and growth on limestone, no models have been developed to quantitatively assess the coating layer growth and its effects on coated limestone dissolution rate. This research was conducted to identify the composition of coating materials and to evaluate coating growth and 
layering. By comparing the neutralization rates of uncoated and coated limestone, the effects of coating thickness on reaction rate were determined and predictions were made as to proper sizing and design of limestone systems that will be coated with iron.

\section{Materials and Methods}

Limestone (from Germany Valley, West Virginia, which is about $98.5 \% \mathrm{CaCO}_{3}$ ), was cut into square chips $(30 \times 30 \times 5 \sim 8 \mathrm{~mm})$. The square chips were washed with dilute acid water and smoothed with fine sandpaper. To control the reaction surface area, five of the six surfaces of each square limestone chip were coated with saran, and then dried for about three hours in an oven $\left(105^{\circ} \mathrm{C}\right)$ for sealing. Recoat this limestone chips three times with the same method. Thus, each square limestone chip only had one available top surface to react with an acid solution, and all square chips had very similar surface areas.

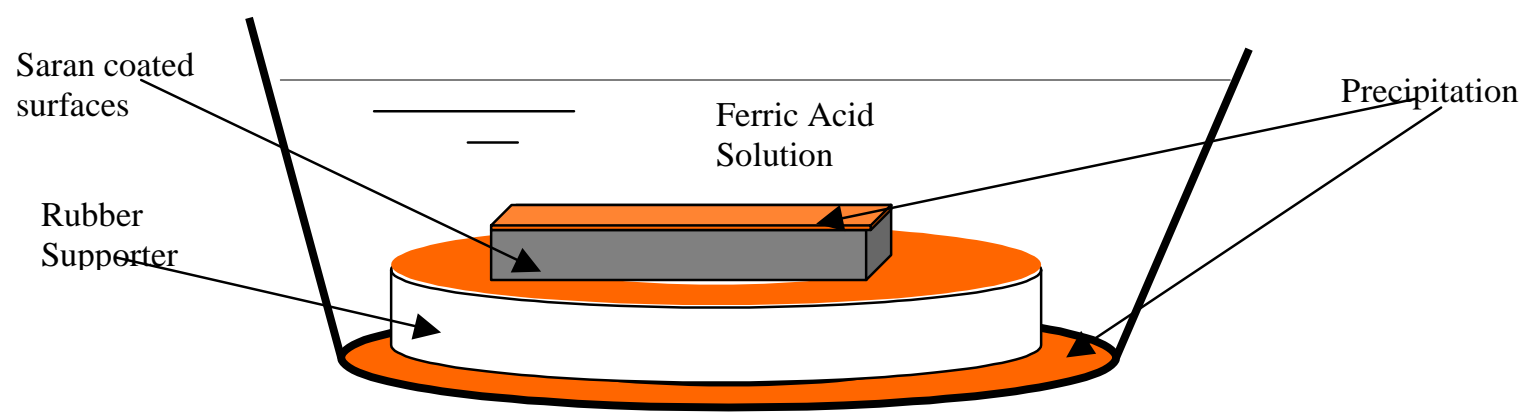

Figure 5.1. Schematic representation of coating method.

Eight square limestone chips were placed in a $1000 \mathrm{ml}$ container filled with 400 $\mathrm{ml}$ of iron acid solution. Four different iron containing acid solutions were allowed to react with individual limestone squares. As the limestone chips neutralized the acid solution, ferric hydroxide precipitated on the limestone surface. The iron solutions (Figure 5.1) were placed in a ventilated hood until the solution evaporated (usually 3 days). The different concentrations of iron in solution caused a slightly different thickness of iron coating on the limestone.

Once the limestone chips were coated with various thicknesses of iron hydroxide and dried, the coating layers were observed and photomicrographs were taken. The 
coating thickness was measured from the ruler in the microscope. The duplicate coating layers were sent for X-ray diffraction, which was usually 1-3 days after microscope observation. The dry, coated limestone chips were then placed into a $400 \mathrm{ml}$ iron acid solution $\left(\left[\mathrm{Fe}^{3+}\right]=0.001 \mathrm{M}, \mathrm{pH} \sim 3.0\right)$ and allowed to react. The ferric acid solutions were made with $\mathrm{FeCl}_{3} * 6 \mathrm{H}_{2} \mathrm{O}$ and deionized water. During the experiment, small solution samples (about $2 \mathrm{~mL}$ ) were taken at predetermined time intervals, and filtered with a $0.45-\mu \mathrm{m}$ syringe-operated filter (Millipore) for chemical analysis. The $\mathrm{pH}$ of the solution was measured at the time of extraction (Accumet $\mathrm{pH}$ meter 25, Fisher Scientific Company, Accu-pHast Electrode) and the withdrawn water samples were analyzed for $\mathrm{Ca}$ and Fe concentration with either Inductively Coupled Plasma (Perkin Elmer P4000) or Atomic Absorption Spectroscopy (Perkin Elmer 5000).

\section{Results and Discussion}

Because of the small amount of surface area of the limestone chips, iron acid solutions were neutralized very slowly. But due to the different acid concentrations, more concentrated iron solutions created thicker coatings (Table 5.1).

Table 5.1. Coating thickness as a function of iron solution concentration.

\begin{tabular}{ccc}
\hline $\begin{array}{c}\text { Fe Concentration } \\
\text { Mol/L }\end{array}$ & \multicolumn{2}{c}{ Coating Thickness } \\
\cline { 2 - 3 } & $\begin{array}{c}\text { Range } \\
\mu \mathrm{m}\end{array}$ & $\begin{array}{c}\text { Average } \\
\mu \mathrm{m}\end{array}$ \\
\hline 0.010 & $40 \sim 50$ & 45 \\
0.006 & $25 \sim 35$ & 30 \\
0.004 & $15 \sim 25$ & 20 \\
0.002 & $10 \sim 15$ & 12.5 \\
0.001 & $5 \sim 10$ & 7.5 \\
\hline
\end{tabular}

The photomicrographs of the coatings on the limestone chip's top surface are shown in Figures 5.2 through 5.4. The moisture of the coating layer controlled the shape and binding strength of the coating materials. When the moisture was high, the coating layer appeared smooth and even. When dried, the coating cracked so seriously that some of it stripped off. The number and width of cracks in the coating not only depended on the coating thickness and moisture content, but also depended on the drying rate. When 
dried under room conditions, cracks were fewer and less deep than when dried under a ventilated hood (Figure 5.3).

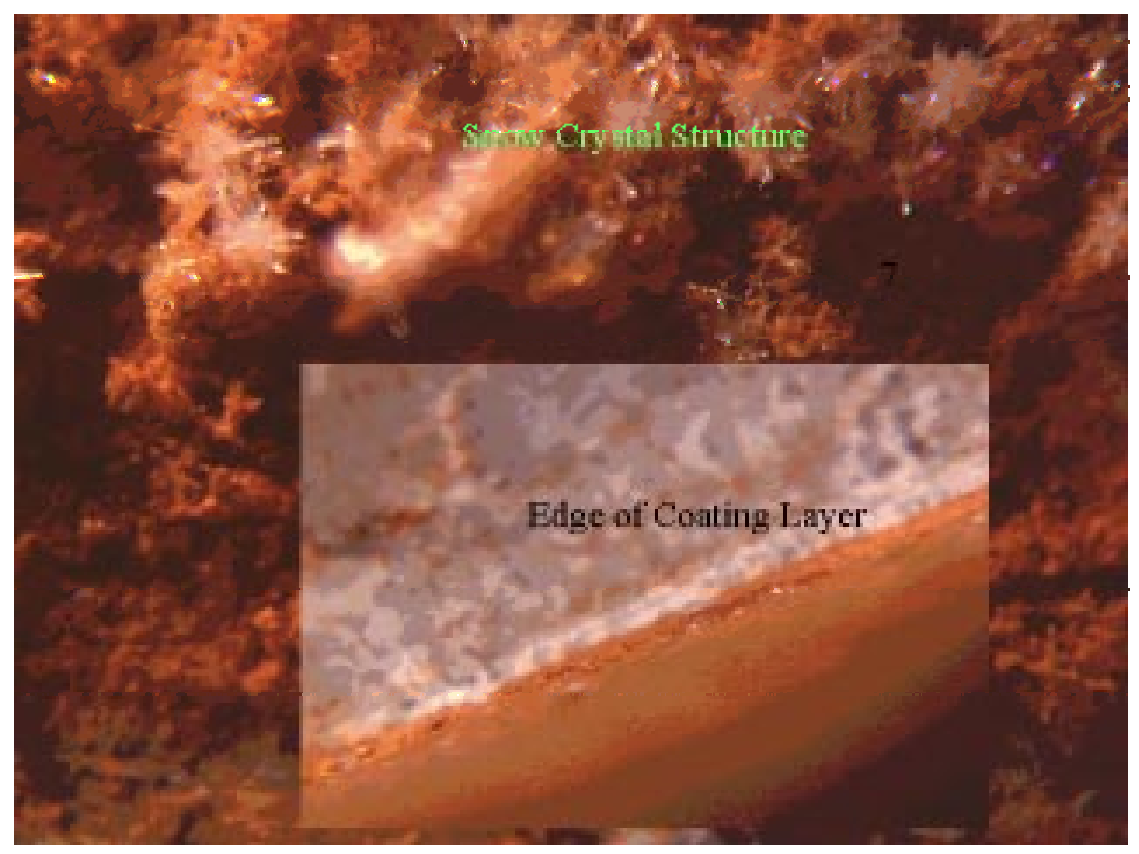

Figure 5.2. The coating layer structure.

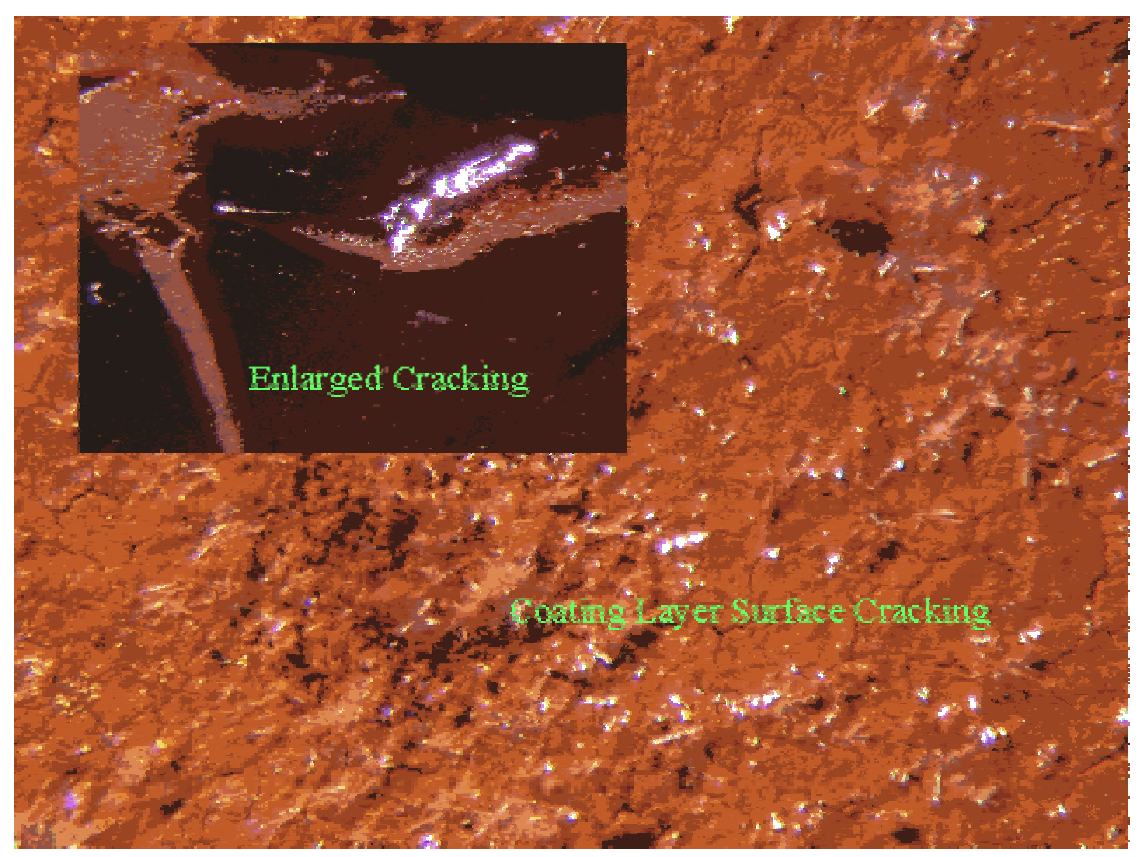

Figure 5.3. Cracking on the coating layer. 


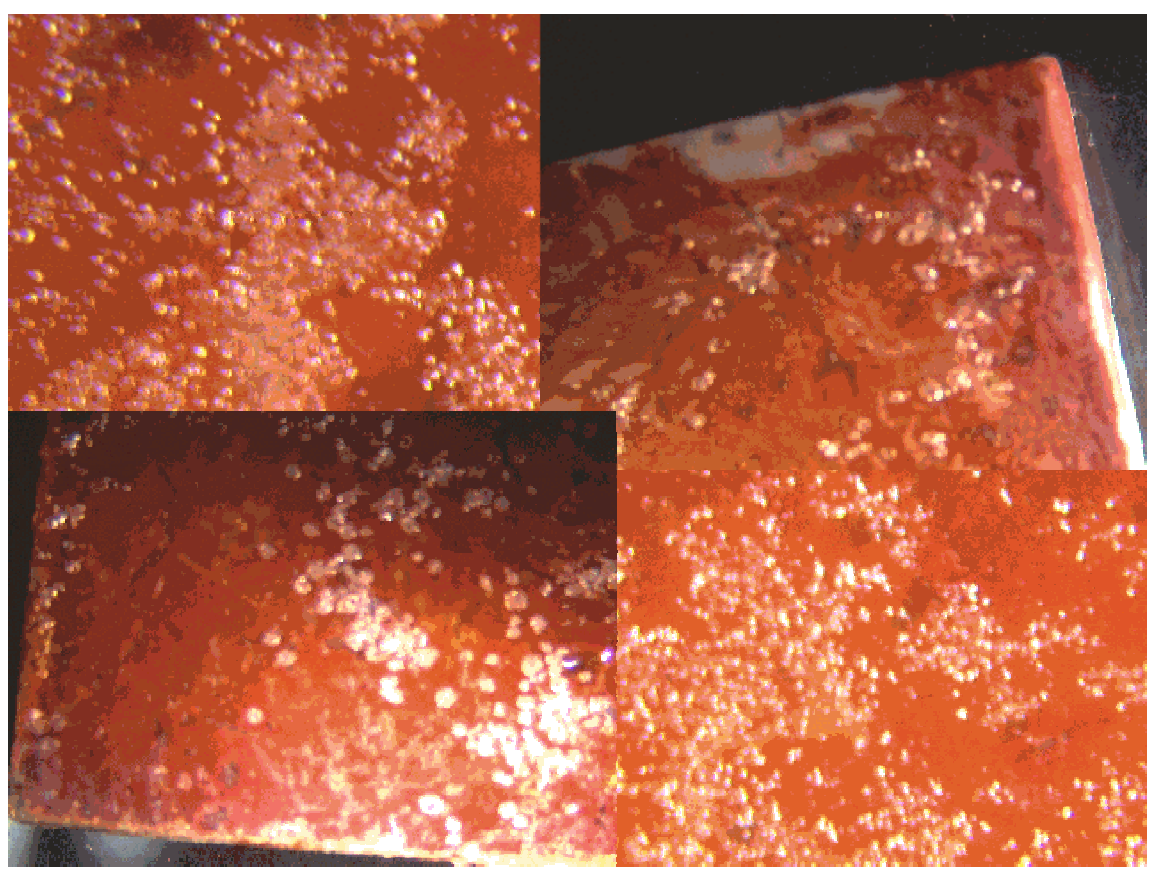

Figure 5.4. The micro-pits on the surface of the coating layer.

One of the intriguing findings of this study was the observation of small pits forming in the coating (Figure 5.4). From microscopic observation, the bottom of the small cone-shaped pits directly connected to the limestone surface. The generation and release of $\mathrm{CO}_{2}$ gas from the limestone surface may cause the formation of these pits.

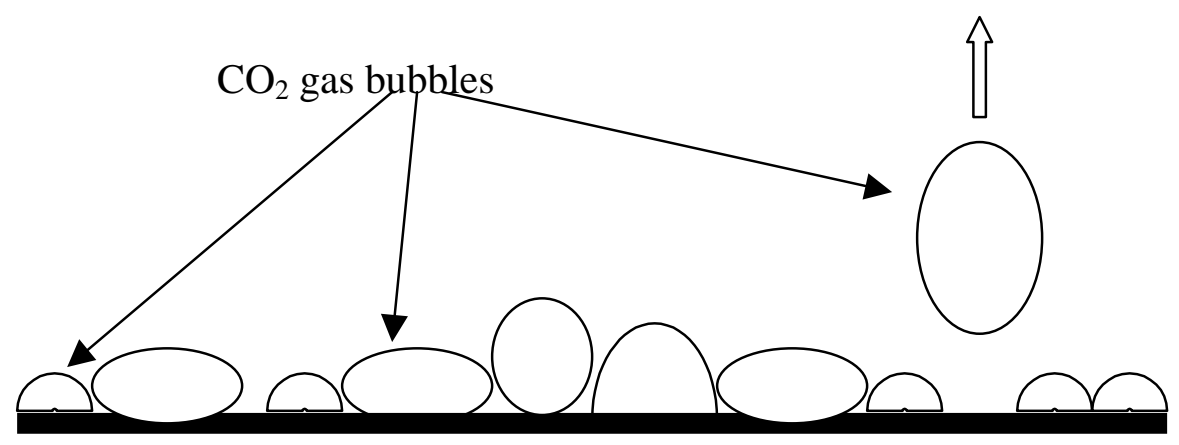

Limestone Surface

Figure 5.5. The $\mathrm{CO}_{2}$ gas bubbles cover limestone surface. 


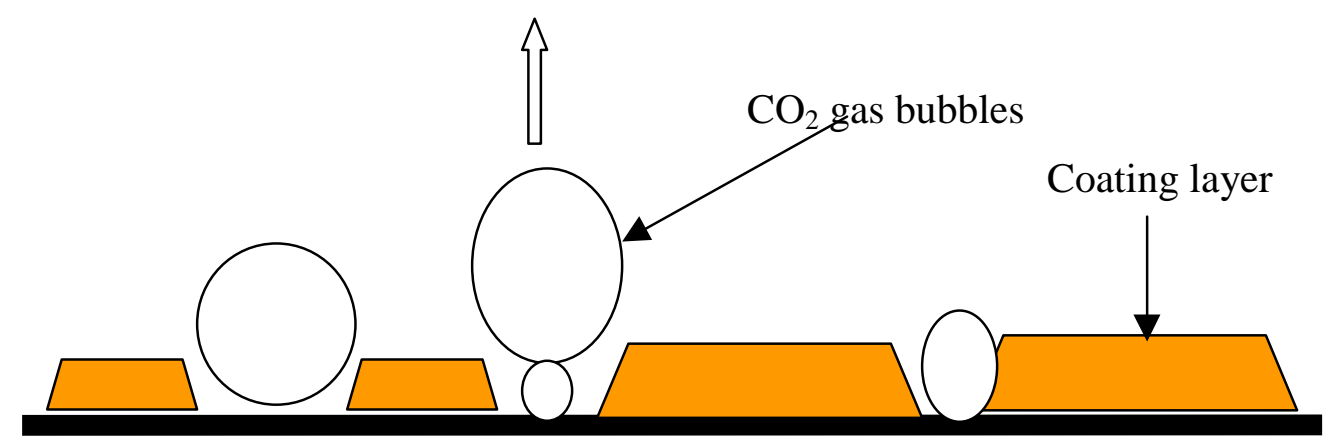

Limestone Surface

Figure 5.6. Pit formation in limestone coating layer.

At the very beginning of the neutralization process when the solution $\mathrm{pH}$ was near 3.0, the fresh limestone surface was covered by numerous, fine gas bubbles (Figure 5.5). As the gas bubbles enlarged, they eventually overcame the adsorption forces and the force of the solution holding them down, and rose in the solution and were released to the air. As the $\mathrm{pH}$ rose to about 5.0, no more gas bubbles were evident. As iron hydrolysis, neutralization, and precipitation began, iron hydroxides formed around the gas bubbles (Figure 5.4) leaving a sparkled appearance. These gas pits became the available reaction surfaces for limestone with acid, and the coated surface hindered the reaction rate (Figure 5.6).

Since dissolved iron concentration never increased (Figure 5.7), iron hydroxide dissolution is not considered a significant $\mathrm{H}^{+}$consuming reaction. The overall neutralization rate increased as the thickness of the coating layer decreased (Figure 5.8). The time required to reach $\mathrm{pH} 5.5$ is $120 \%$ longer with $12.5 \mu \mathrm{m}$ coating and $275 \%$ longer with a $20 \mu \mathrm{m}$ coating, compared to no coating. Figure 5.9 indicates that the rate of calcium release to the solution is reduced by a coating, but is independent of coating thickness. 


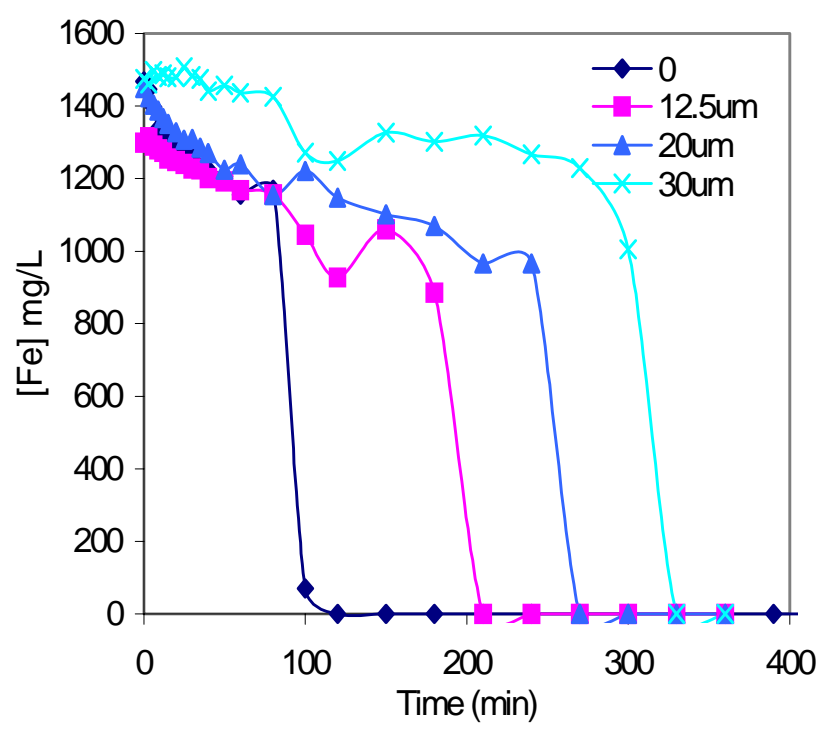

Figure 5.7. Coating thickness effects on iron removal.

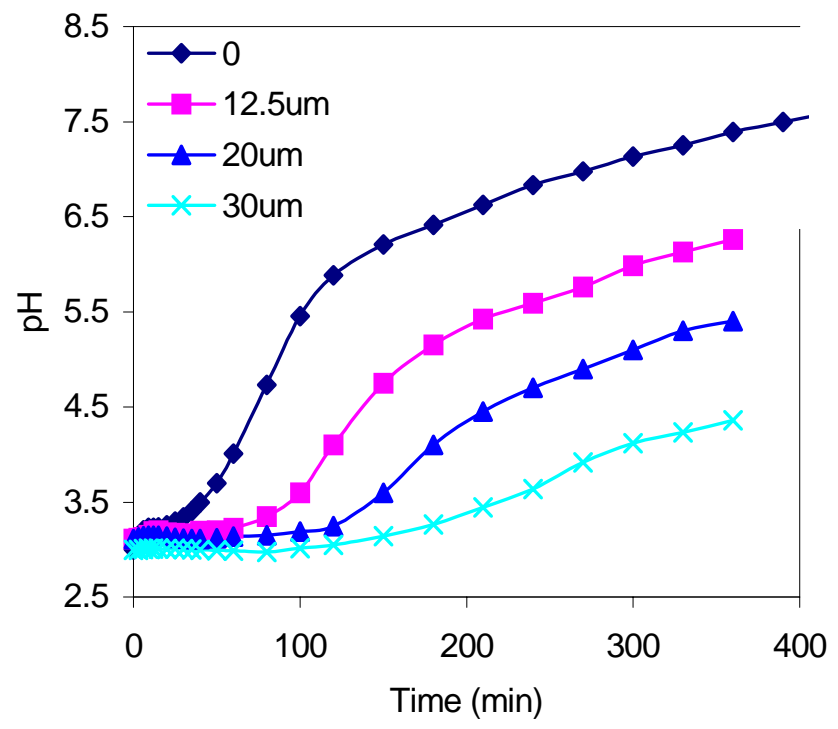

Figure 5.8. Coating thickness effects on neutralization rate at initial iron concentration $0.001 \mathrm{M}$. 


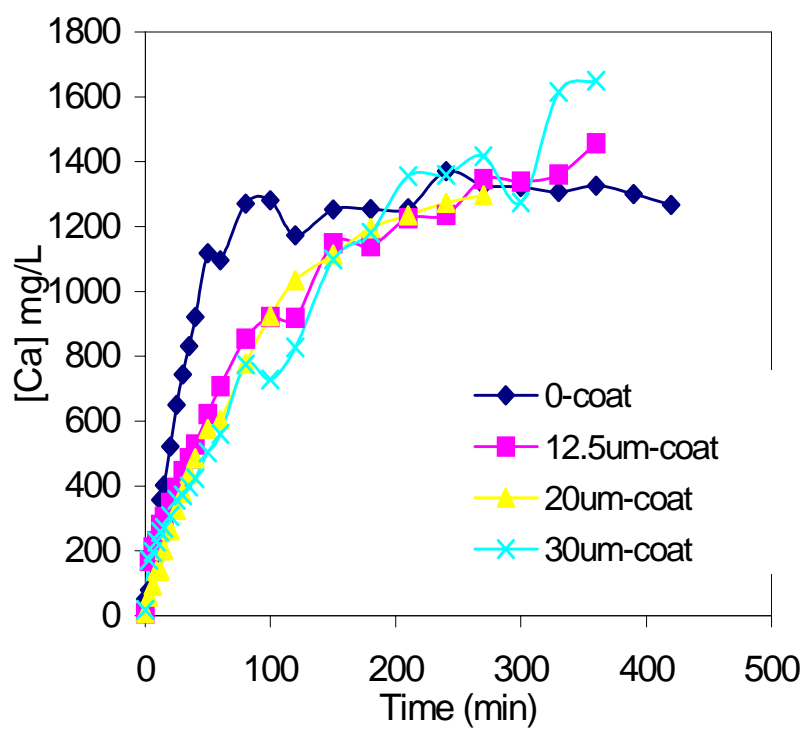

Figure 5.9. Coating thickness effects on calcium concentration vs. time at initial iron concentration of $0.001 \mathrm{M}$.

If the general function for acid neutralization by fresh limestone is given by $p H_{\text {fresh }}=f(t)$, then an efficiency factor to account for the effect of a coating, $\mathrm{K}$, can be introduced such that:

$$
p H=K * f(t)=K^{*} p H_{\text {fresh }}
$$

Regressing the $\mathrm{pH}$ difference between the neutralization by coated limestone and fresh limestone with the coating thickness (Figure 5.7), an empirical equation for $\mathrm{K}$ was determined as:

$$
\mathrm{K}=-0.0098 \mathrm{~b}+1.003
$$

where $b$ is the coating thickness $(\mu \mathrm{m})$. The overall function is then given as:

$$
\mathrm{pH}=(-0.0098 \mathrm{~b}+1.003) \mathrm{pH}_{\text {fresh }}
$$


The required reaction time for fresh limestone particles neutralizing iron acid solutions was given in Chapter 4 as:

$$
\begin{aligned}
& \mathrm{t}(\mathrm{Fe})=\left[\left(-75.08 p H_{f}+338.27\right) p H_{i}+0.8053 p H_{f}^{3.5346}\right] A_{M S}\left(-0.1305 p H_{f}+0.6185\right) p H i+\left(0.7365 p H_{f}-4.5918\right) \\
& \quad+(42 \ln [\mathrm{Fe}]+35.1) p H_{f}-176 \ln [\mathrm{Fe}]-143
\end{aligned}
$$

where: $\mathrm{t}(\mathrm{Fe})=$ required reaction time $(\mathrm{min})$;

$$
\begin{aligned}
& \mathrm{pH}_{\mathrm{f}}=\text { the final outlet } \mathrm{pH} ; \\
& \mathrm{pHi}=\text { initial } \mathrm{pH} \text { of acid solution; } \\
& \mathrm{A}_{\mathrm{MS}}=\text { specific surface area of limestone particles }\left(\mathrm{cm}^{2} / \mathrm{g}\right) ; \\
& {[\mathrm{Fe}]=\text { ferric iron concentration of the acid solution }(\mathrm{mmol} / \mathrm{L}) .}
\end{aligned}
$$

For coated limestone particles, limestone surface area is not as effective as fresh surfaces, so it should take longer to reach the desired final $\mathrm{pH}$. Thus, the general required retention time should be corrected by an efficiency constant, $\eta$ :

$$
\mathrm{t}=\eta^{*} \mathrm{t}(\mathrm{Fe})
$$

where $t$ is the required retention time for coated limestone, $t(\mathrm{Fe})$ is the required retention time for fresh limestone. From the required reaction time to reach $\mathrm{pH}$ 5.0, 5.5 and 6.0, an empirical equation for $\eta$ was determined from Figure 5.7 as:

$$
\eta=e^{0.0654 b}
$$

where $b$ is again the thickness $(\mu \mathrm{m})$ of the coating layer. The overall equation for the effect of armoring on the neutralization of acid solutions containing iron is then:

$$
\begin{gathered}
t=e^{0.0654 b}\left\{\left[\left(-75.08 p H_{f}+338.27\right) p H_{i}+0.8053 p H_{f}^{3.5346}\right] A_{M S}^{\left(-0.1305 p H_{f}+0.6185\right) p H i+\left(0.7365 p H_{f}-4.5918\right)}\right. \\
\left.+(42 \ln [\mathrm{Fe}]+35.1) p H_{f}-176 \ln [\mathrm{Fe}]-143\right\}
\end{gathered}
$$


The coating layer directly influenced the removal rate of iron from solution. The time required (Figure 5.8) to completely remove $0.001 \mathrm{M}$ Fe from solutions was a linear function of the coating thickness:

$\mathrm{t}($ Fe removal $)=4.1404 \mathrm{~b}+126.67$

where $\mathrm{t}$ is the time of iron totally removed from the solution (min) and $\mathrm{b}$ is the thickness of coating layer $(\mu \mathrm{m})$.

\section{Example:}

To show how the coating affects limestone treatment systems, the following example is given.

Suppose an AMD source has $1000 \mathrm{~L} / \mathrm{min}$ of effluent and the water has an initial $\mathrm{pH}$ of 3.0 (acidity $10^{-3} \mathrm{M}$ or $50 \mathrm{mg} / \mathrm{L}$ as $\mathrm{CaCO}_{3}$ ), but also contains $55 \mathrm{mg} / \mathrm{L}$ of iron. If the outlet $\mathrm{pH}$ is specified to be 7.0 and the open limestone channel is designed for 10 years, the retention time based on an optimal limestone particle size $(\mathrm{d}=9.18 \mathrm{~mm}$ for hydrogen acid solution) should be increased to 245 minutes (Example II). Assume the coating growth rate is $4 \mu \mathrm{m}$ per year, we can predict the final $\mathrm{pH}$ and the lifetime of the limestone treatment system.

\begin{tabular}{|l|}
\hline Inflow: \\
$\mathrm{pH}_{\text {initial }}=3.0$ \\
{$[\mathrm{Fe}]=55 \mathrm{mg} / \mathrm{L}$} \\
$\mathrm{Q}=1000 \mathrm{~L} / \mathrm{min}$
\end{tabular}

Coating growth rate
$4 \mu \mathrm{m} /$ year
$\begin{aligned} & \text { Required retention time } \\ & \mathrm{t}=245 \mathrm{~min}\end{aligned}$

Limestone required for 10 years is:

$$
\begin{aligned}
\mathrm{W}_{0} & =10 *\left(0.309 \mathrm{C}_{\mathrm{T}}+0.27\left[\mathrm{Fe}^{3+}\right]_{\mathrm{i}}+0.448\right) \mathrm{Q} * 365 * 24 * 60 * 50 * 100 \\
& =1,027,022,400 \mathrm{~g}=1,027,022.4 \mathrm{~kg}
\end{aligned}
$$

From Figure 5.7, the final $\mathrm{pH}$ for the reaction time of 245 minutes is a function of coating thickness (Eq. 5) :

$\mathrm{pH}=\mathrm{K}^{*} \mathrm{pH}_{\text {fresh }}=(-0.0098 \mathrm{~b}+1.003) \mathrm{pH}_{\text {fresh }}$ 
So the final $\mathrm{pH}$ of each year can be predicted and is shown in Table 5.2. The effective lifespan (outlet $\mathrm{pH}$ over 6.0) of the limestone treatment system is only about 3.5 years.

Table 5.2. Coating effects on outlet water quality.

\begin{tabular}{cccc}
\hline Year & $\begin{array}{c}\text { Outlet } \mathrm{pH} \text { in } \\
\text { fresh limestone system }\end{array}$ & $\begin{array}{c}\text { Coating Thickness } \\
\mu \mathrm{m}\end{array}$ & $\begin{array}{c}\text { Outlet } \mathrm{pH} \text { in } \\
\text { coated limestone system }\end{array}$ \\
\hline 1 & 7.00 & 0 & 7.00 \\
2 & 6.92 & 4 & 6.67 \\
3 & 6.74 & 8 & 6.24 \\
4 & 6.48 & 12 & 5.74 \\
5 & 6.15 & 16 & 5.20 \\
6 & 5.77 & 20 & 4.66 \\
7 & 5.37 & 24 & 4.12 \\
8 & 4.97 & 28 & 3.62 \\
9 & 4.58 & 32 & 3.16 \\
10 & 4.24 & 36 & 3.00 \\
\hline
\end{tabular}

\section{Conclusion}

In coal mining areas, iron hydroxides and other iron minerals are the predominate coating materials on limestone surfaces in AMD treatment systems. The water flow rate and iron concentration have a great influence on the coating layer growth, so higher iron concentration and air exposure will enhance the coating layer formation in open limestone channels. The thickness of the coating layer is a function of iron concentration. As concentrations of iron in solution increase, the coating layer becomes thicker.

The thickness of the coating layer and the micro pits on the coating surface may greatly affect the neutralization rate of acid solutions by limestone. A general equation to estimate the required reaction time is derived for an open limestone system using empirically determined efficiency factors. An efficiency constant, $\eta$, was introduced to correct the reaction time required for neutralization of iron containing acid solutions with coated limestone. By knowing the water chemistry (acidity, $\mathrm{pH}$, and iron) and the type and size of a limestone treatment system (amount and size of limestone), we can more accurately predict the treatment efficiency and longevity of the system for treating a specified AMD flow. 


\section{References}

Christiansen, J. H., and A. E. Nielson. 1951. Acta Chem. $2^{\text {nd }}$ Edition 5: 673.

Loeppert, R. H., L. R. Hossner, and P. K. Amin. 1984. Formation of ferric oxyhydroxides from ferrous and ferric perchlorate in stirred calcareous systems. Soil Sci. Soc. Am. J. 48:677-683.

Loeppert, R. H., and L. R. Hossner. 1984. Reactions of $\mathrm{Fe}^{2+}$ and $\mathrm{Fe}^{3+}$ with calcite. Clays and Clay Minerals. Vol.32(3):213-222.

Maree, J. P., P. D. Plessis, and C. J. Van der Walt. 1992. Treatment of acidic effluents with limestone instead of lime. Wat. Sci. Tech. 26(1-2):345-355.

Pearson, F. H. and A. J. McDonnell. 1977. "Characterization of Coarse Porous Media," J of the Env. Eng. Div., ASCE, Vol. 103:615-624.

Schwertmann, U., and E. Murad. 1983. Effect of $\mathrm{pH}$ on the formation of goethite and hematite from ferrihydrite. Clays and Clay Minerals. Vol. 31(4):277-28.

Snoeyink, V. L., and D. Jenkins. 1980. Water Chemistry. John Willey \& Sons, New York.

Sung, W., and J. J. Morgan. 1981. Oxidative removal of Mn(II) from solution catalysed by the $\gamma-\mathrm{FeOOH}$ (lepidocrocite) surface. Geochimica et Cosmochimica Acta. 45:2377-2383.

Ziemkiewicz, P.F., J.G. Skousen, and R. Lovett. 1994. Open limestone channels for treating acid mine drainage: a new look at an old idea. Green Lands 24(4):36-41. 
Ziemkiewicz, P.F., J.G. Skousen, D.L. Brant, P.L. Sterner, and R.J. Lovett. 1997. Acid mine drainage treatment with armored limestone in open limestone channels. J. of Environ. Qual, 26(4):1017-1024.

\section{Supporting information}

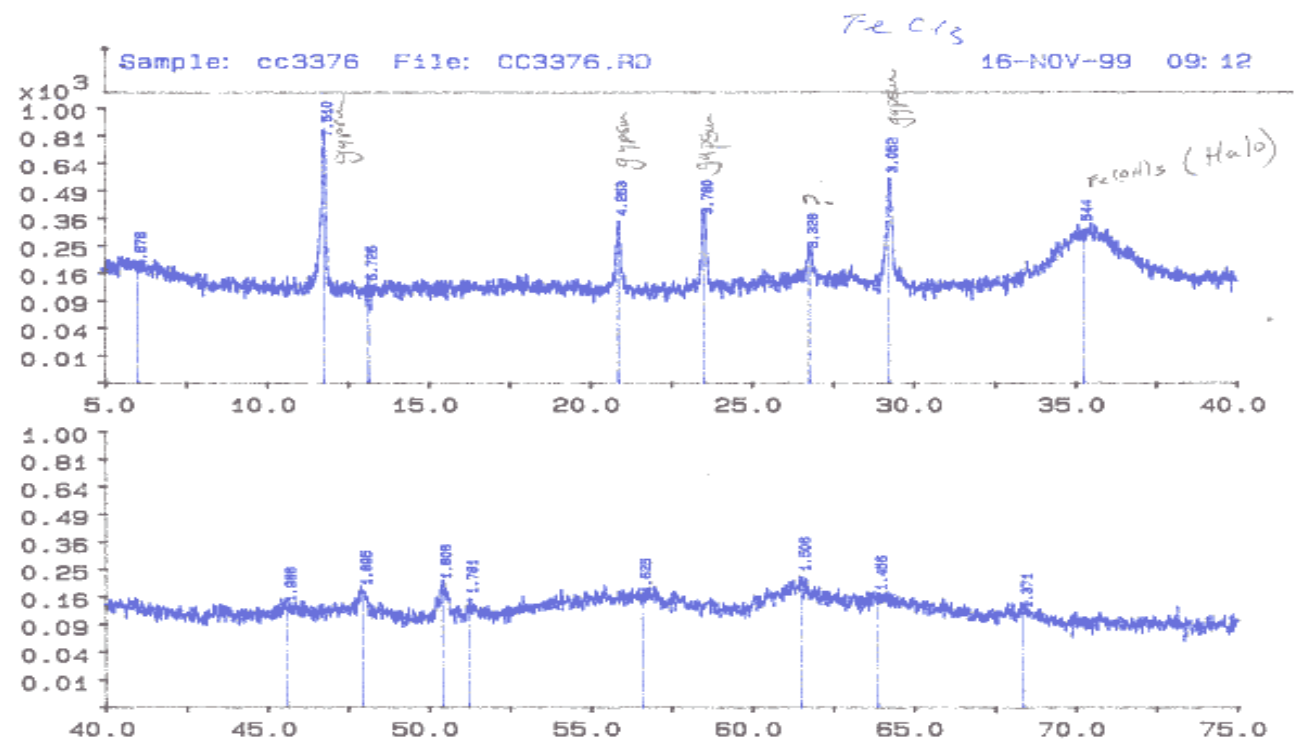

Figure 5.10. X-ray diagram of $\mathrm{FeCl}_{3}$ coated layer.

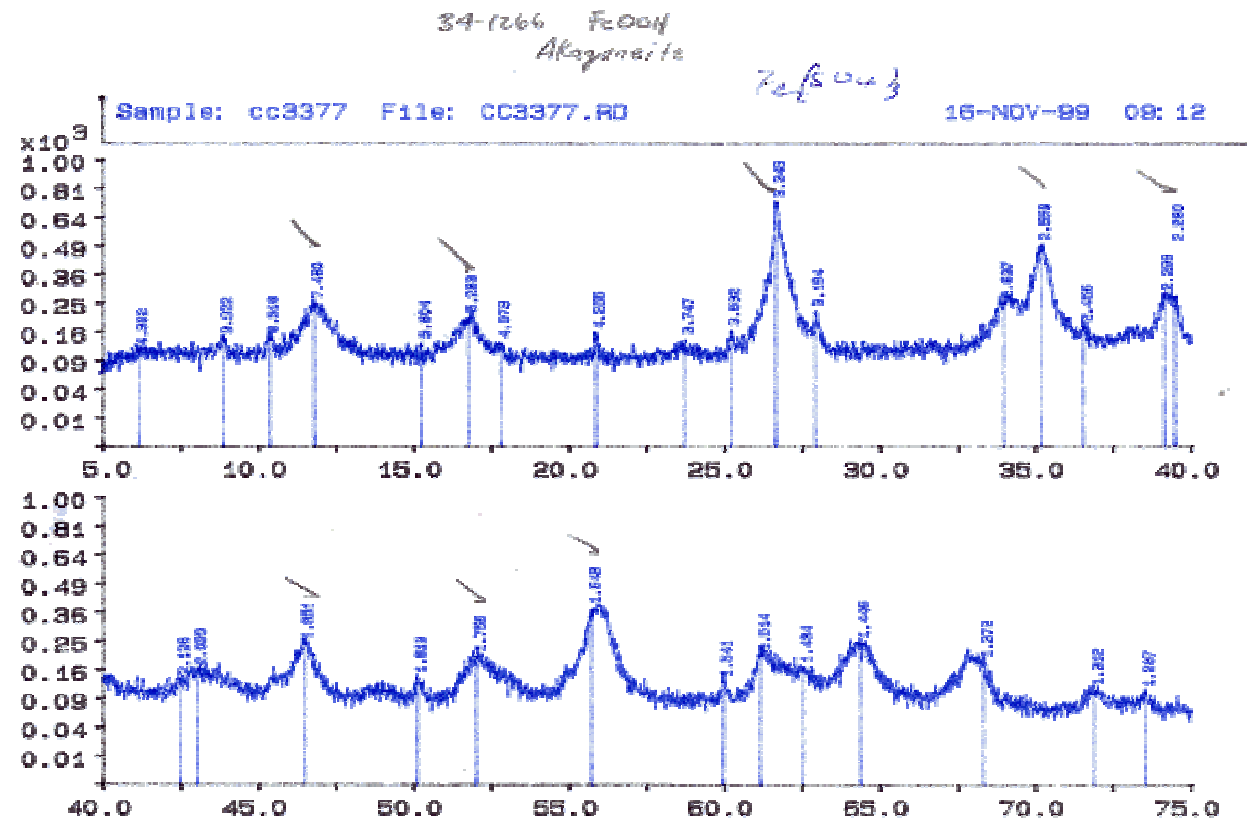

Figure 5.11. X-ray diagram of $\mathrm{Fe}_{2}\left(\mathrm{SO}_{4}\right)_{3}$ coated layer. 

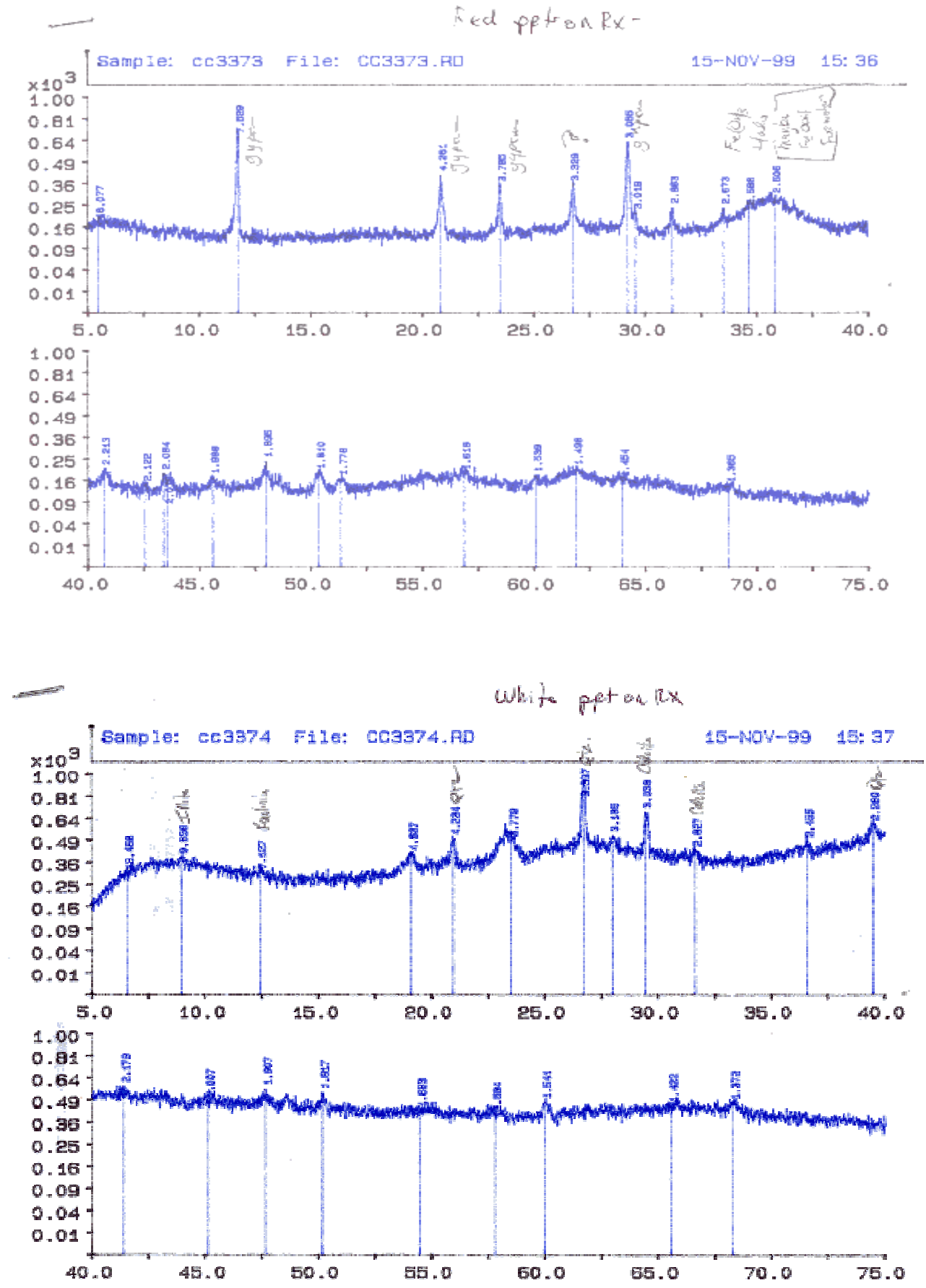

Figure 5.12. The X-ray diagram of the coating layer in field OLCs. 


\section{Chapter 6. Open Limestone Channel Design Models and the Prediction of Water Treatment}

Today's design for open limestone systems is based solely on the acid load of an acid mine drainage outflow, which does not consider the chemical composition of the water, nor the slope of the land. Our research on the neutralization rate of acid mine drainage by limestone showed that the iron concentration, water flow rate, and limestone properties have great influences on limestone coating and acid removal, which determines the outlet water quality. Therefore, there is a need to design optimal limestone systems for field AMD treatment and to predict water quality in the future.

This spreadsheet model optimizes open limestone system design and predicts water treatment effects during the life of the system based on previous research on required reaction time for iron acid solutions and coating formation. Because the coating thickness depends on the flow rate (flushing force) and iron concentration, land slope and its effect on water flow velocity have been incorporated into the model. Iron concentrations of the AMD and its influence on coating growth have also been included in the model. Based on the required reaction time and land slope, we can design the length of an open limestone channel as well as the limestone particle size to optimize its performance.

For fresh open limestone systems, we can predict the outlet water $\mathrm{pH}$ based on the field design. By considering the limestone surface area decreasing and estimating iron concentration effects on coating growth rate, the outlet water $\mathrm{pH}$ in an old limestone system can be predicted by this spreadsheet model. Therefore, we can predict the system's effectiveness for treating AMD over time and make modifications or replace the system once the outlet $\mathrm{pH}$ becomes too low. 
Table 6.1 Input Spreadsheet

\begin{tabular}{|c|c|c|c|}
\hline STREAM & VALUE & UNITS & SYMBOL \\
\hline $\mathrm{pHi}$ & 3 & & pHi \\
\hline Expected Final pH & 7 & & $\mathrm{pHf}$ \\
\hline$[\mathrm{Fe} 3+]$ & 50 & $\mathrm{mg} / \mathrm{L}$ & {$[\mathrm{Fe} 3+]$} \\
\hline$[\mathrm{Fe} 2+]$ & 0 & $\mathrm{mg} / \mathrm{L}$ & {$[\mathrm{Fe} 2+]$} \\
\hline$[\mathrm{Al} 3+]$ & 0 & $\mathrm{mg} / \mathrm{L}$ & {$[\mathrm{Al} 3+]$} \\
\hline$[\mathrm{Mn} 2+]$ & 0 & $\mathrm{mg} / \mathrm{L}$ & [Mn2+] \\
\hline$[\mathrm{Zn} 2+]$ & 0 & $\mathrm{mg} / \mathrm{L}$ & {$[\mathrm{Zn} 2+]$} \\
\hline$[\mathrm{Cu} 2+]$ & 0 & $\mathrm{mg} / \mathrm{L}$ & {$[\mathrm{Cu} 2+]$} \\
\hline$[\mathrm{Cu}+]$ & 0 & $\mathrm{mg} / \mathrm{L}$ & {$[\mathrm{Cu}+]$} \\
\hline Others & 0 & $\mathrm{mmol} / \mathrm{L}$ & {$[\mathrm{M}]$} \\
\hline Flow Rate & 500 & GPM & Qo \\
\hline Final Acidity & 10 & $\mathrm{mg} / \mathrm{L}$ & Af \\
\hline Total Calculated Acidity & 3.68 & $\mathrm{meq} / \mathrm{L}$ & $A c=10^{3-p H}+\sum^{C_{i}} / M_{i} Z_{i}$ \\
\hline & 184.2 & $\begin{array}{c}\mathrm{mg} / \mathrm{L} \\
\mathrm{CaCO} 3\end{array}$ & Acid $_{t}=50 \mathrm{Ac}$ \\
\hline Total Measured Acidity(as CaCO3) & 150.0 & $\begin{array}{c}\mathrm{mg} / \mathrm{L} \\
\mathrm{CaCO} 3\end{array}$ & $\mathrm{Ai}$ \\
\hline CHANNEL"S CHARACTER & & & \\
\hline Depth & 3 & $\mathrm{ft}$ & $\mathrm{D}$ \\
\hline Top Width & 10 & $\mathrm{ft}$ & W1 \\
\hline Bottom Width & 6 & $\mathrm{ft}$ & W2 \\
\hline Void Ratio & 35 & $\%$ & $\mathrm{R}$ \\
\hline Slope & 20.00 & $\%$ & $\mathrm{k}$ \\
\hline Hydraulic Conductivity K & 0.10 & $\mathrm{~cm} / \mathrm{s}$ & $\mathrm{K}$ \\
\hline LIMESTONE & & & \\
\hline Average Particle Size & 2.0 & in. & $\mathrm{d}$ \\
\hline Shape Factor & 0.20 & & $\mathrm{r}$ \\
\hline Cost of Limestone/Placement & 15 & $\$ /$ ton & $\mathrm{P}$ \\
\hline Limestone Density & 2.2 & $\mathrm{Mg} / \mathrm{m}^{3}$ & $\rho$ \\
\hline
\end{tabular}




\section{Table 6.2 Results Spreadsheet}

\begin{tabular}{|c|c|c|c|}
\hline STREAM & VALUE & UNITS & EQUATION \\
\hline Flow Rate & 1.11 & $\mathrm{ft}^{3} / \mathrm{sec}$ & $\mathrm{Q}=0.1137 / 60 * \mathrm{Qo}$ \\
\hline Outlet $\mathrm{pH}$ & 7 & & Expected final $\mathrm{pH}$ \\
\hline Final Acidity & 10 & $\mathrm{mg} / \mathrm{L}$ & Measured \\
\hline Final Acid Load & 11 & tons/year & $\mathrm{Af}^{*} \mathrm{Qo} * 0.0022$ \\
\hline Original Acid Load & 164.5 & tons/year & Acid load $=\mathrm{Ai} * \mathrm{Qo} * 0.0022$ \\
\hline Acid Removal & 93.33 & $\%$ & $\left(\mathrm{~A}_{\mathrm{i}}-\mathrm{A}_{\mathrm{f}}\right) / \mathrm{A}_{\mathrm{f}}$ \\
\hline Coating Growth Rate & 5 & um/year & $\mathrm{B}=2\left[\mathrm{Fe}^{3+}\right] / \mathrm{k}$ \\
\hline Stream Cross Section & 24 & $\mathrm{ft}^{2}$ & $\mathrm{So}=(\mathrm{W} 1+\mathrm{W} 2) / 2 * \mathrm{D}$ \\
\hline Stream Initial Velocity & 0.1326 & $\mathrm{ft} / \mathrm{sec}$ & $\mathrm{Vo}=\mathrm{Q} /\left(\mathrm{So}^{*} \mathrm{R}\right)$ \\
\hline \multicolumn{4}{|l|}{ Residence Time } \\
\hline Retention Time $(\mathrm{Fe}=0)$ & 107.50 & $\min$ & $\begin{array}{c}\mathrm{t}=\left[\left(-75.08 p H_{f}+338.27\right) p H_{i}+0.8053 p H_{f}^{3.5346}\right]^{*} \\
A_{M S}{ }^{\left(-0.1305 p H_{f}+0.6185\right) p H i+\left(0.7365 p H_{f}-4.5918\right)}\end{array}$ \\
\hline Retention Time $(\mathrm{Fe})$ & 234 & $\min$ & $\mathrm{t}=\mathrm{t}(\mathrm{Fe}=0)+(42 \ln \mathrm{Fe}+35.1) * \mathrm{pH}_{\mathrm{f}}-176 \ln \mathrm{Fe}-143$ \\
\hline Total Required Reaction Time & 3.90 & hours & $\mathrm{T}=\mathrm{t} / 60$ \\
\hline \multicolumn{4}{|l|}{ Limestone Channel } \\
\hline Specific Surface Area & 9.3 & $\mathrm{~cm}^{2} / \mathrm{g}$ & $A_{M S}=3.6635 d^{0.9828} / r$ \\
\hline Slope Caused dH/dl & 0.20 & & $d H / d l=k / \sqrt{1+k^{2}}$ \\
\hline Slope Caused Velocity & 0.0021 & $\mathrm{ft} / \mathrm{Sec}$. & $V_{x}=K / R * d H / d l$ \\
\hline Required Length & 1890 & $\mathrm{ft}$ & $\mathrm{L}=\mathrm{t}(\mathrm{Vx}+\mathrm{Vo})$ \\
\hline Construction Required LS & 2021 & tons & $\mathrm{LS}=\mathrm{So} * \mathrm{~L} * \rho$ \\
\hline Cost of Channel & 30310 & $\$$ & $\$=\mathrm{P} * \mathrm{LS}$ \\
\hline Limestone Consumption Rate & 99 & tons/Year & $\operatorname{RLS}=(\mathrm{Ai}-\mathrm{Af}) \mathrm{Q}$ \\
\hline Life of Drain & 20 & years & Y=LS/RLS \\
\hline
\end{tabular}




\section{Table 6.3 Outlet Water Quality Prediction}

\begin{tabular}{|c|c|c|c|c|c|c|c|c|}
\hline \multirow{2}{*}{\multicolumn{2}{|c|}{$\begin{array}{c}\text { Year Limestone } \\
\text { Remains } \\
\text { Tons }\end{array}$}} & \multicolumn{3}{|c|}{ Fresh Limestone System } & \multicolumn{4}{|c|}{ Coated Limestone System } \\
\hline & & $\begin{array}{c}\text { Outlet } \\
\mathrm{pH}\end{array}$ & $\begin{array}{c}\text { Outlet } \\
\text { Fe }\end{array}$ & $\begin{array}{c}\text { Final } \\
\text { Acidity }\end{array}$ & $\begin{array}{c}\text { Coating } \\
\text { Thickness }\end{array}$ & $\begin{array}{c}\text { Outlet } \\
\mathrm{pH}\end{array}$ & $\begin{array}{c}\text { Outlet } \\
\text { Fe }\end{array}$ & $\begin{array}{c}\text { Final } \\
\text { Acidity }\end{array}$ \\
\hline & & & ppm & ppm & $\mu \mathrm{m}$ & & ppm & ppm \\
\hline 1 & 2020.7 & 7.00 & 0 & 10.0 & 0 & 7.00 & 0 & 10.0 \\
\hline 2 & 1922 & 6.97 & 0 & 10.0 & 2 & 6.86 & 0 & 10.0 \\
\hline 3 & 1823.3 & 6.89 & 0 & 10.0 & 4 & 6.64 & 0 & 10.0 \\
\hline 4 & 1724.6 & 6.77 & 0 & 10.0 & 6 & 6.39 & 0 & 10.0 \\
\hline 5 & 1625.9 & 6.61 & 0 & 10.0 & 8 & 6.11 & 0 & 10.0 \\
\hline 6 & 1527.2 & 6.40 & 0 & 10.0 & 10 & 5.80 & 0 & 10.1 \\
\hline 7 & 1428.6 & 6.17 & 0 & 10.0 & 12 & 5.46 & 0 & 10.2 \\
\hline 8 & 1329.9 & 5.92 & 0 & 10.1 & 14 & 5.12 & 0 & 10.4 \\
\hline 9 & 1231.2 & 5.65 & 0 & 10.1 & 16 & 4.78 & 0 & 10.8 \\
\hline 10 & 1132.5 & 5.37 & 0 & 10.2 & 18 & 4.44 & 20 & 29.7 \\
\hline 11 & 1033.8 & 5.09 & 0 & 10.4 & 20 & 4.11 & 20 & 31.8 \\
\hline 12 & 935.17 & 4.82 & 0 & 10.8 & 22 & 3.80 & 20 & 35.9 \\
\hline 13 & 836.49 & 4.56 & 0 & 11.4 & 24 & 3.50 & 20 & 43.5 \\
\hline 14 & 737.81 & 4.32 & 20 & 30.2 & 26 & 3.23 & 20 & 57.0 \\
\hline 15 & 639.13 & 4.10 & 20 & 31.8 & 28 & 3.00 & 20 & 77.9 \\
\hline 16 & 540.45 & 3.91 & 20 & 34.1 & 30 & 3.00 & 20 & 77.9 \\
\hline 17 & 441.77 & 3.73 & 20 & 37.1 & 32 & 3.00 & 20 & 77.9 \\
\hline 18 & 343.08 & 3.59 & 20 & 40.8 & 34 & 3.00 & 20 & 77.9 \\
\hline 19 & 244.4 & 3.46 & 20 & 45.2 & 36 & 3.00 & 20 & 77.9 \\
\hline 20 & 145.72 & 3.36 & 20 & 49.9 & 38 & 3.00 & 20 & 77.9 \\
\hline 21 & 47.044 & 3.27 & 20 & 54.7 & 40 & 3.00 & 20 & 77.9 \\
\hline 22 & 0 & 3.00 & 20 & 59.1 & 42 & 3.00 & 20 & 77.9 \\
\hline
\end{tabular}


Based on derived models, we calculated the errors between the theory values and experimental data by the following statistics functions:

$$
\begin{aligned}
& R^{2}=1-\frac{S S E}{S S T} \\
& S S E=\sum\left(Y_{i}-\hat{Y}_{i}\right)^{2} \\
& S S E=\sum Y_{i}^{2}-\frac{\left(\sum Y_{i}\right)^{2}}{n}
\end{aligned}
$$

1. For proton acid solution, the required reaction time is:

$t=\left[\left(-75.08 p H_{f}+338.27\right) p H_{i}+0.8053 p H_{f}^{3.5346}\right] A_{M S}{ }^{\left(-0.1305 p H_{f}+0.6185\right) p H i+\left(0.7365 p H_{f}-4.5918\right)}$

Where $\mathrm{t}$ is reaction time required to reach a final $\mathrm{pH}, \mathrm{pH}_{\mathrm{f}}$ is the final $\mathrm{pH}$ and $\mathrm{pH}_{\mathrm{i}}$ is initial $\mathrm{pH}$, and $\mathrm{A}_{\mathrm{MS}}$ is mass specific surface area. 
Figure 6.1 Prediction of required time to reach final $\mathrm{pH} 5.5$ vs. different limestone particles.

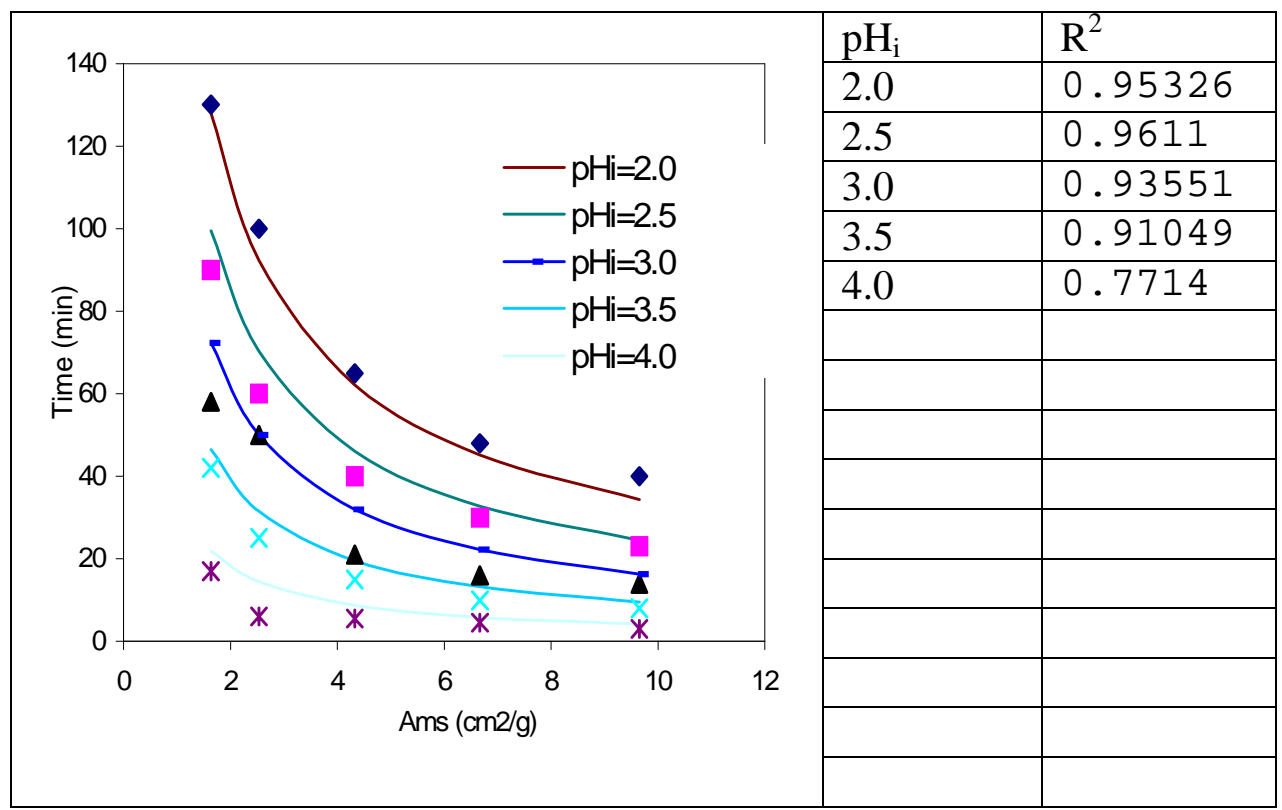

Figure 6.2 Prediction of required time to reach final $\mathrm{pH} 6.0$ vs. different limestone particles.

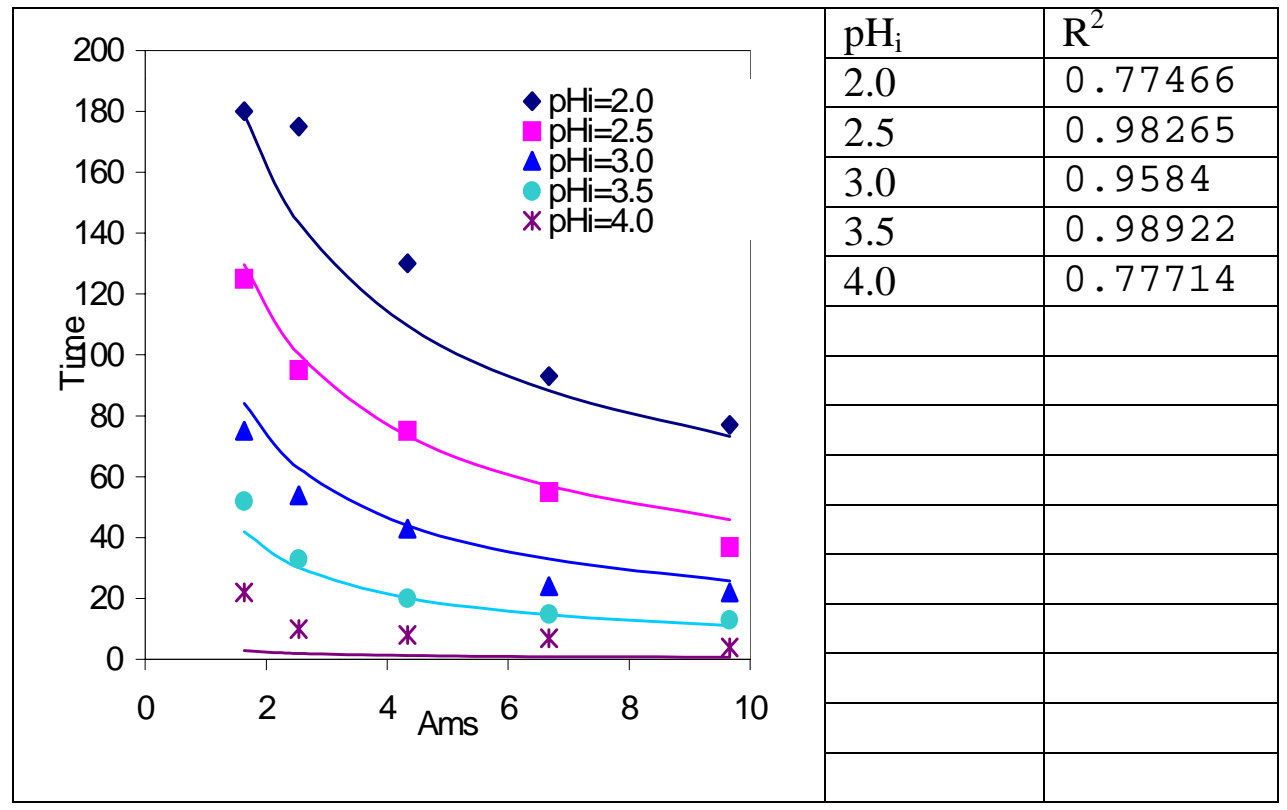


Figure 6.3 Prediction of required time to reach final $\mathrm{pH} 6.5$ vs. different limestone particles.

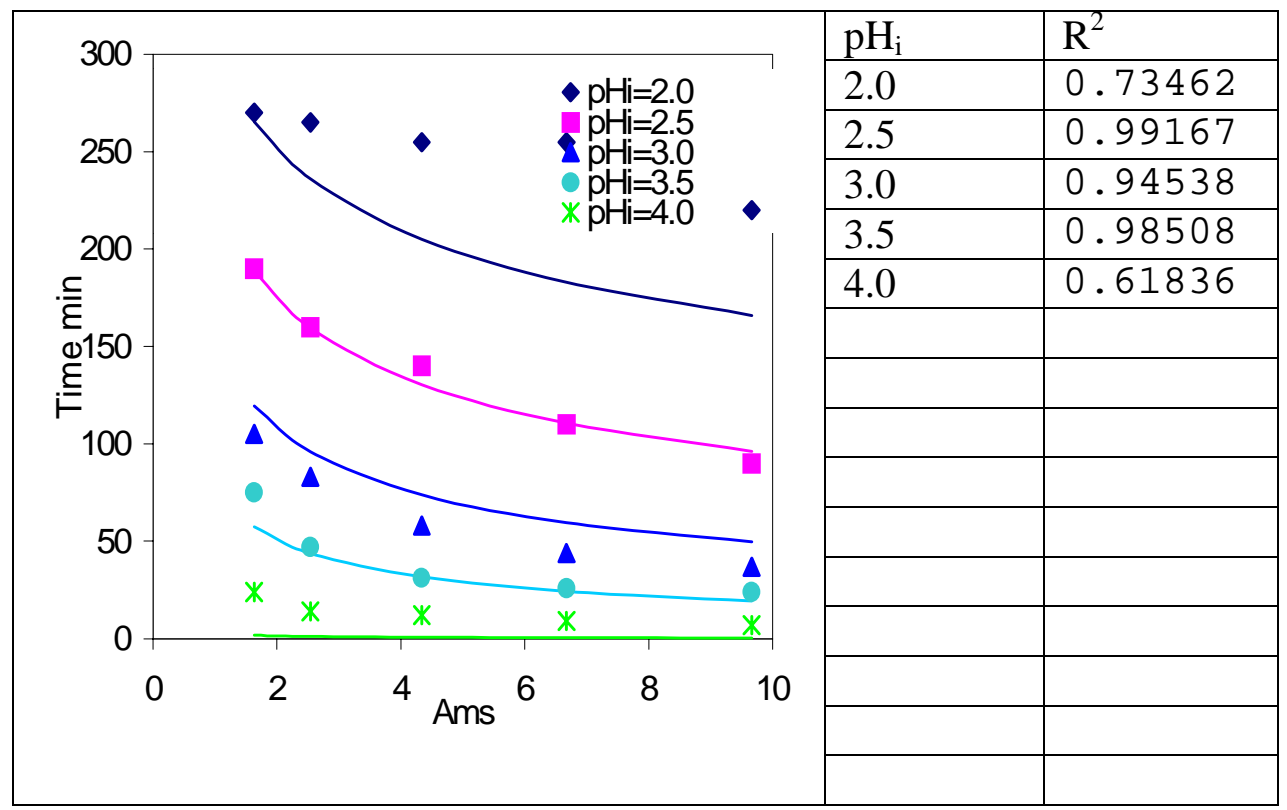

Figure 6.4 Prediction of required time to reach final $\mathrm{pH} 7.0$ vs. different limestone particles.

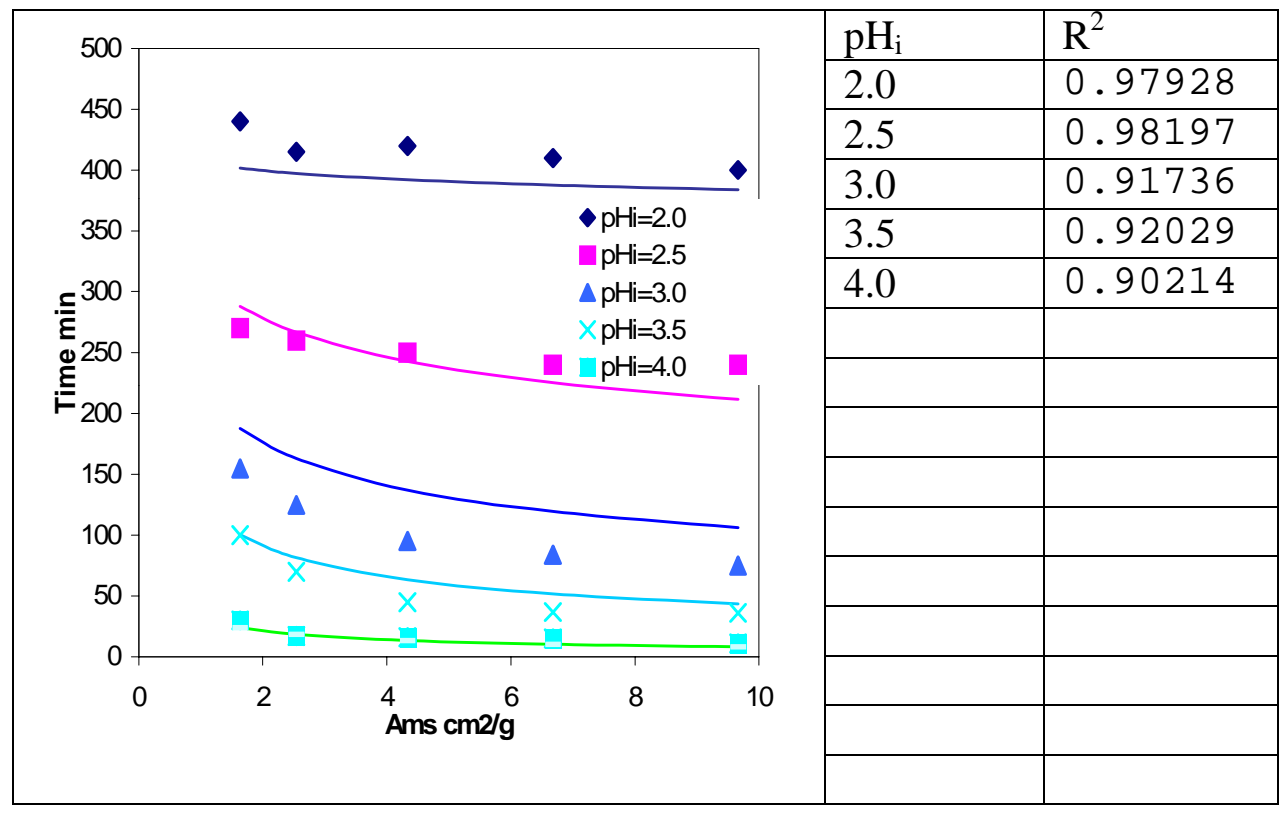


2. For iron solutions, the required reaction time is calculated by:

$$
\begin{aligned}
& \mathrm{t}(\mathrm{Fe})=\left[\left(-75.08 p H_{f}+338.27\right) p H_{i}+0.8053 p H_{f}^{3.5346}\right] A_{M S}\left(-0.1305 p H_{f}+0.6185\right) p H i+\left(0.7365 p H_{f}-4.5918\right) \\
& \quad+(42 \ln [\mathrm{Fe}]+35.1) p H_{f}-176 \ln [\mathrm{Fe}]-143
\end{aligned}
$$

Where: $\mathrm{t}(\mathrm{Fe})=$ required reaction time $(\mathrm{min})$;

$\mathrm{pH}_{\mathrm{f}}=$ the final outlet $\mathrm{pH}$;

$\mathrm{pHi}=$ initial $\mathrm{pH}$ of acid solution;

$\mathrm{A}_{\mathrm{MS}}=$ specific surface area of limestone particles $\left(\mathrm{cm}^{2} / \mathrm{g}\right)$;

$[\mathrm{Fe}]=$ ferric iron concentration of the acid solution $(\mathrm{mmol} / \mathrm{L})$.

Figure 6.5 Prediction of required time to reach a final $\mathrm{pH}$ in iron acid solutions.

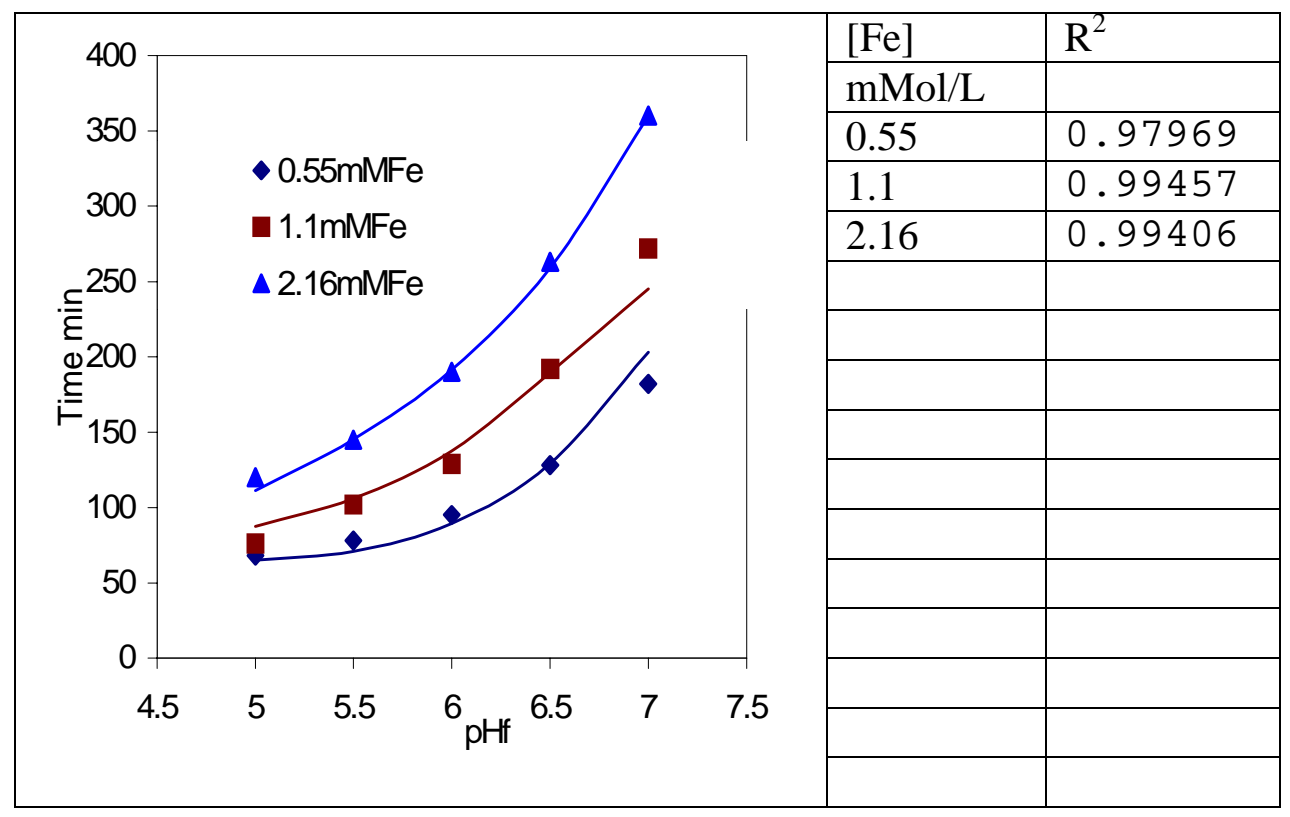


3. To coated limestone, the required reaction time is:

$t=e^{0.0654 b}\left\{\left[\left(-75.08 p H_{f}+338.27\right) p H_{i}+0.8053 p H_{f}^{3.5346}\right] A_{M S}{ }^{\left(-0.1305 p H_{f}+0.6185\right) p H i+\left(0.7365 p H_{f}-4.5918\right)}\right.$

$\left.(42 \ln [\mathrm{Fe}]+35.1) p H_{f}-176 \ln [\mathrm{Fe}]-143\right\}$

Where $t$ is the required retention time for coated limestone, $b$ is again the thickness $(\mu \mathrm{m})$ of the coating layer.

Figure 6.6 Prediction of required time to reach a final $\mathrm{pH}$ with coated limestone.

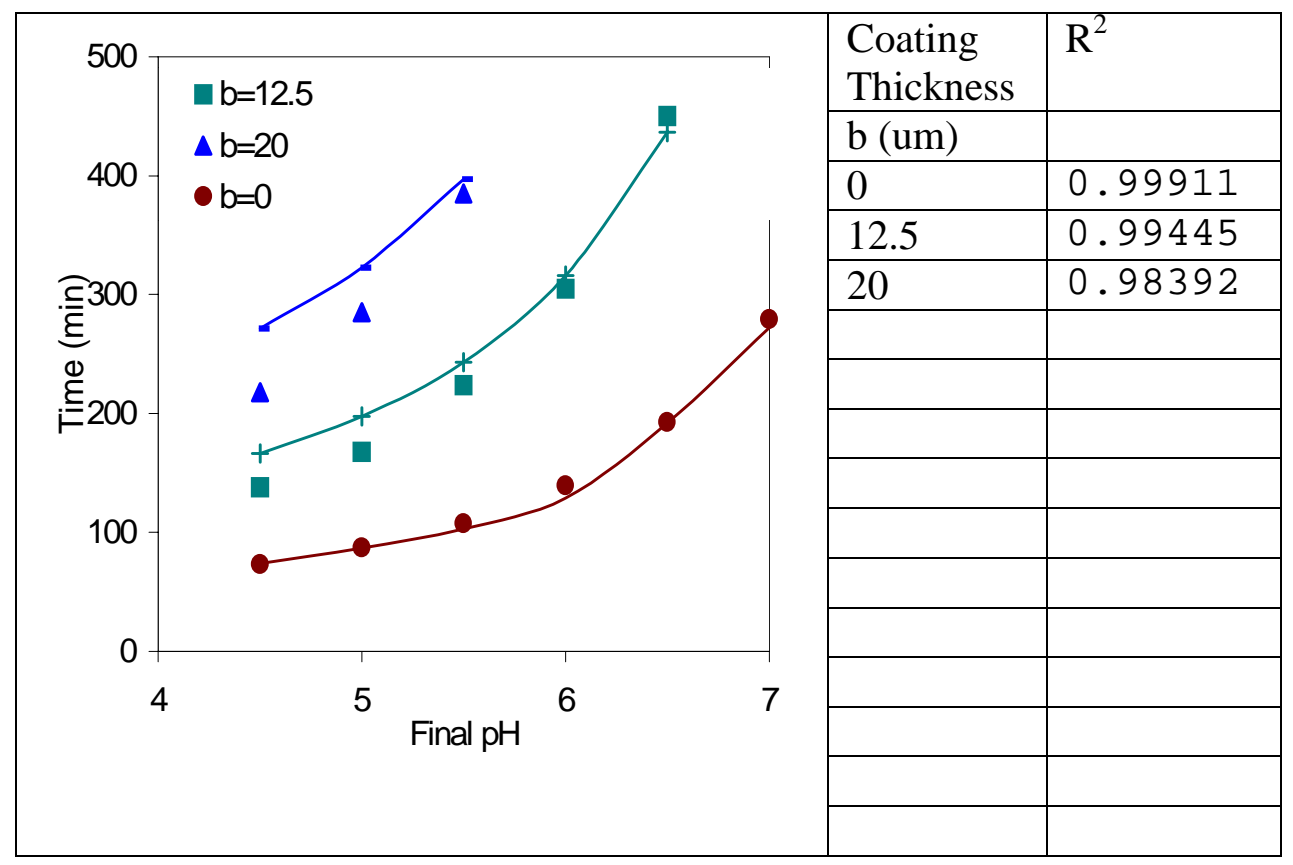




\section{Appendix}

\section{Experimental Data Sheet and Figures}


Appendix Table 7.1.1 Initial pH 4.0 vs. Particle Sizes

\begin{tabular}{|c|c|c|c|c|c|c|c|}
\hline $1.1-4.0$ & pH vs. & Partic & le Sizes & & & & $\begin{array}{r}\mathrm{pH}=4.0 \\
8-26-1998\end{array}$ \\
\hline & & Soil Size & $2.0-4.65$ & 4.75-6.3 & 6.3-11 & $11.0-19.0$ & $19-25$ \\
\hline & & Weight $(\mathrm{g})$ & 99.448 & 99.536 & 99.53 & 99.648 & 99.515 \\
\hline & & Last Wt. & 99.439 & 99.53 & 98.682 & 99.638 & 99.499 \\
\hline & & & $\mathrm{pH}$ & $\mathrm{pH}$ & $\mathrm{pH}$ & $\mathrm{pH}$ & $\mathrm{pH}$ \\
\hline & Time & React t & $2.0-4.65$ & $4.75-6.3$ & $6.3-11$ & $11.0-19.0$ & 19-25 \\
\hline 1 & $10: 05$ & 0 & 3.98 & \begin{tabular}{|l|}
3.99 \\
\end{tabular} & 3.99 & \begin{tabular}{|l|}
3.98 \\
\end{tabular} & 4.00 \\
\hline 2 & 7 & 2 & 4.87 & 4.31 & 4.22 & 4.14 & 4.15 \\
\hline 3 & 9 & 4 & 6.01 & 5.42 & 4.60 & 4.37 & 4.28 \\
\hline 4 & 13 & 8 & 6.66 & 6.34 & 6.08 & 5.80 & 4.65 \\
\hline 5 & 19 & 14 & 7.45 & 6.94 & 6.76 & 6.50 & 5.14 \\
\hline 6 & 24 & 19 & 8.66 & 8.63 & 8.30 & 7.66 & 5.79 \\
\hline 7 & 30 & 25 & 9.07 & 9.04 & 8.88 & 7.86 & 6.67 \\
\hline 8 & 37 & 32 & 9.21 & 9.24 & 9.15 & 8.10 & 7.10 \\
\hline 9 & 45 & 40 & 9.26 & 9.30 & 9.23 & 8.80 & 7.30 \\
\hline 10 & $11: 05$ & 60 & 9.35 & 9.31 & 9.30 & 9.13 & 7.59 \\
\hline & $12: 20$ & 135 & 9.28 & 9.33 & 9.32 & 9.32 & 9.23 \\
\hline
\end{tabular}


Appendix Table 7.1.2 Initial pH 3.5 vs. Particle Sizes

\begin{tabular}{|c|c|c|c|c|c|c|c|}
\hline & & Soil Size & $2.0-4.65$ & $4.75-6.3$ & $6.3-11$ & $11.0-19.0$ & $19-25$ \\
\hline & & Weight $(\mathrm{g})$ & 99.566 & 99.545 & 99.542 & 99.652 & 99.523 \\
\hline & & Last Wt. & 99.448 & 99.536 & 99.53 & 99.648 & 99.515 \\
\hline & & \multicolumn{6}{|c|}{ Each beaker filled with $400 \mathrm{ml}$ water solution $\mathrm{pH}=3.448,3.45,3.452$} \\
\hline & Time & React t & $2.0-4.65$ & $4.75-6.3$ & 6.3-11 & $11.0-19.0$ & $19-25$ \\
\hline 1 & 9:40 & 0 & 3.45 & 3.45 & 3.45 & 3.45 & 3.45 \\
\hline 2 & 41 & 1 & 3.61 & 3.51 & 3.45 & 3.45 & 3.46 \\
\hline 3 & 43 & 3 & 3.89 & 3.87 & 3.60 & 3.58 & 3.49 \\
\hline 4 & 46 & 6 & 5.19 & 4.39 & 4.00 & 3.68 & 3.58 \\
\hline 5 & 49 & 9 & 5.64 & 5.38 & 4.26 & 3.87 & 3.64 \\
\hline 6 & 52 & 12 & 5.98 & 5.76 & 5.13 & 4.02 & 3.76 \\
\hline 7 & 56 & 16 & 6.16 & 6.10 & 5.62 & 4.37 & 3.85 \\
\hline 8 & $10: 00$ & 20 & 6.38 & 6.28 & 6.00 & 4.76 & 4.03 \\
\hline 9 & 5 & 25 & 6.53 & 6.44 & 6.23 & 5.48 & 4.20 \\
\hline 10 & 10 & 30 & 6.84 & 6.80 & 6.50 & 5.81 & 4.60 \\
\hline 11 & 17 & 37 & 7.08 & 7.01 & 6.67 & 6.19 & 5.07 \\
\hline 12 & 25 & 45 & 7.79 & 7.28 & 7.04 & 6.40 & 5.75 \\
\hline 13 & 35 & 55 & 8.29 & 7.91 & 7.34 & 6.74 & 6.05 \\
\hline 14 & 45 & 65 & 8.32 & 8.02 & 7.73 & 6.94 & 6.30 \\
\hline 15 & 11:00 & 80 & 8.44 & 8.42 & 8.12 & 7.32 & 6.66 \\
\hline 16 & 20 & 100 & 8.46 & 8.49 & 8.46 & 7.62 & 7.00 \\
\hline 17 & 55 & 135 & 8.44 & 8.49 & 8.55 & 8.43 & 7.51 \\
\hline 18 & $12: 25$ & 165 & 8.45 & 8.55 & 8.51 & 8.43 & 7.87 \\
\hline 19 & $15: 00$ & 320 & 8.42 & 8.47 & 8.61 & 8.56 & 8.49 \\
\hline
\end{tabular}


Appendix Table 7.1.3 Initial pH 3.0 vs. Particle Sizes

\begin{tabular}{|l|l|l|l|l|l|l|l|l|l|l|}
\hline 1.1-3.0 pH VS. Particle Sizes & \multicolumn{7}{|c|}{ 24.3 oC; pH=3.0; 10:00, 8-10-1998 } \\
\begin{tabular}{|l|l|l|l|l|l|l|l|l|} 
Soil \\
Size
\end{tabular} & $\begin{array}{l}4.0- \\
4.65\end{array}$ & $\begin{array}{l}4.75- \\
6.3\end{array}$ & $6.3-11$ & $\begin{array}{l}11.0- \\
19.0\end{array}$ & $19-25$ & & & & & \\
\hline $\begin{array}{l}\text { Weight } \\
\text { g) }\end{array}$ & 99.598 & 99.583 & 99.567 & 99.68 & 99.555 & & & & & \\
\hline $\begin{array}{l}\text { Last } \\
\text { Wt. }\end{array}$ & 99.566 & 99.545 & 99.542 & 99.652 & 99.523 & & & & & \\
\hline
\end{tabular}

Each beaker filled with $400 \mathrm{ml}$ water solution $\mathrm{pH}=3.046,2.993, \mathrm{Ca}$ in the solution without 2.989 diluted

\begin{tabular}{|r|r|r|r|r|r|r|r|r|r|r|}
\hline React t & $\begin{array}{l}2.0- \\
\text { 4.65 }\end{array}$ & $\begin{array}{l}4.75- \\
6.3\end{array}$ & $\begin{array}{l}6.3-11 \\
11.0-\end{array}$ & $19-25$ & $\begin{array}{l}2.0- \\
4.0\end{array}$ & $\begin{array}{l}4.75- \\
6.3\end{array}$ & $6.3-11$ & $\begin{array}{l}11.0- \\
19.0\end{array}$ & $19-25$ \\
\hline 0 & 3 & 3 & 3 & 3 & 3 & 0 & 0 & 0 & 0 & 0 \\
\hline 1 & 3.12 & 3.08 & 3.02 & 3.00 & 3.02 & 19.50 & -0.12 & 11.93 & 6.52 & 5.46 \\
\hline 5 & 3.37 & 3.42 & 3.25 & 3.13 & 3.07 & 28.41 & 25.73 & 25.40 & 9.66 & 8.54 \\
\hline 8 & 4.05 & 3.96 & 3.75 & 3.23 & 3.16 & 24.37 & 23.56 & 22.56 & 14.20 & 12.41 \\
\hline 12 & 5.19 & 4.86 & 4.14 & 3.38 & 3.29 & 26.86 & 27.41 & 22.83 & 17.16 & 13.72 \\
\hline 15 & 5.54 & 5.44 & 4.67 & 3.60 & 3.40 & 27.53 & 28.06 & 25.47 & 19.39 & 16.16 \\
\hline 19 & 5.83 & 5.74 & 5.32 & 3.76 & 3.50 & 29.83 & 29.01 & 24.70 & 21.98 & 17.27 \\
\hline 23 & 6.07 & 5.98 & 5.65 & 4.11 & 3.69 & 31.00 & 29.29 & 26.38 & 22.65 & 20.93 \\
\hline 28 & 6.20 & 6.10 & 5.83 & 4.53 & 3.79 & 32.48 & 31.14 & 29.86 & 24.08 & 20.57 \\
\hline 33 & 6.35 & 6.26 & 6.01 & 5.10 & 3.94 & 37.57 & 33.64 & 30.72 & 26.80 & 25.37 \\
\hline 39 & 6.51 & 6.40 & 6.20 & 5.49 & 4.30 & 36.54 & 35.54 & 32.19 & 27.94 & 24.18 \\
\hline 47 & 6.66 & 6.54 & 6.31 & 5.83 & 4.68 & 38.76 & 33.31 & 34.40 & 28.05 & 25.18 \\
\hline 55 & 6.82 & 6.66 & 6.48 & 6.03 & 5.38 & 38.92 & 36.73 & 31.98 & 30.01 & 25.24 \\
\hline 65 & 7.02 & 6.83 & 6.61 & 6.21 & 5.71 & 41.86 & 35.95 & 36.47 & 28.05 & 28.42 \\
\hline 75 & 7.13 & 6.92 & 6.76 & 6.39 & 6.01 & 38.43 & 35.32 & 31.39 & 26.62 & 23.99 \\
\hline 85 & 7.27 & 7.06 & 6.81 & 6.51 & 6.20 & 41.62 & 35.72 & 33.41 & 27.20 & 27.22 \\
\hline 100 & 7.51 & 7.24 & 7.05 & 6.73 & 6.45 & 44.07 & 40.72 & 34.20 & 29.87 & 26.55 \\
\hline 125 & 7.84 & 7.51 & 7.35 & 7.04 & 6.75 & 41.16 & 36.19 & 37.76 & 33.28 & 26.61 \\
\hline 155 & 8.02 & 7.79 & 7.67 & 7.33 & 7.04 & 35.59 & 38.13 & 32.38 & 31.07 & -0.20 \\
\hline 185 & 8.05 & 8.02 & 7.94 & 7.62 & 7.34 & 46.29 & 39.26 & 40.84 & 32.28 & 26.59 \\
\hline 230 & 8.07 & 8.05 & 8.09 & 8.02 & 7.83 & 40.51 & 40.38 & 37.04 & 33.42 & 27.96 \\
\hline 290 & 8.17 & 8.17 & 8.21 & 8.29 & 8.22 & 38.39 & 37.38 & 35.82 & 37.78 & 28.34 \\
\hline 350 & 8.26 & 8.21 & 8.25 & 8.35 & 8.35 & -0.20 & -0.20 & 43.68 & 51.32 & 55.09 \\
\hline 1365 & 8.01 & 8.03 & 8.12 & 8.17 & 8.03 & & & & & \\
\hline
\end{tabular}


Appendix Table 7.1.4 Initial pH 2.5 vs. Particle Sizes

\begin{tabular}{|c|c|c|c|c|c|c|c|c|c|c|c|}
\hline \multicolumn{12}{|c|}{$\begin{array}{r}\text { 1.1-2.5 pH vs. Particle } \\
\text { Sizes }\end{array}$} \\
\hline $\begin{array}{l}\text { Soil } \\
\text { Size }\end{array}$ & $\begin{array}{l}2.0- \\
4.65\end{array}$ & $\begin{array}{l}4.75- \\
6.3\end{array}$ & $6.3-11$ & \begin{tabular}{|l|}
$11.0-$ \\
19.0
\end{tabular} & $19-25$ & & & & & & \\
\hline $\begin{array}{l}\text { Weight } \\
\text { (g) }\end{array}$ & 99.499 & 99.593 & 99.398 & 99.776 & 99.653 & \multicolumn{6}{|c|}{$\begin{array}{r}\text { Each beaker filled with } 400 \mathrm{ml} \text { water solution } \mathrm{pH}= \\
2.431,2.432\end{array}$} \\
\hline $\begin{array}{l}\text { Last } \\
\text { Wt. }\end{array}$ & 99.387 & 99.104 & 99.573 & 99.682 & 99.555 & \multicolumn{6}{|c|}{$\mathrm{Ca}$ in the solution without diluted } \\
\hline React t & $\begin{array}{l}2.0- \\
4.65\end{array}$ & $\begin{array}{l}4.75- \\
6.3\end{array}$ & $6.3-11$ & $\begin{array}{l}11.0- \\
19.0\end{array}$ & $19-25$ & & $\begin{array}{l}2.0- \\
4.65\end{array}$ & $\begin{array}{l}4.75- \\
6.3\end{array}$ & $6.3-11$ & $\begin{array}{l}11.0- \\
19.0\end{array}$ & $19-25$ \\
\hline 0 & 2.43 & 2.43 & 2.43 & \begin{tabular}{|l|}
2.43 \\
\end{tabular} & 2.43 & 4.3 & $\begin{array}{r}76.7 \\
\end{array}$ & \begin{tabular}{|l|}
24.7 \\
\end{tabular} & 85.8 & \begin{tabular}{|l|}
30.7 \\
\end{tabular} & 18.6 \\
\hline 2 & 2.55 & 2.47 & 2.45 & 2.44 & 2.43 & 7.2 & 93.3 & 67.4 & 64.6 & 42.2 & 31.1 \\
\hline 5 & 3.08 & 2.68 & 2.79 & 2.56 & 2.52 & 9.5 & 97.0 & 80.6 & 79.5 & 56.4 & 41.0 \\
\hline 9 & 3.67 & 2.98 & 2.85 & 2.68 & 2.58 & 12.5 & 113.3 & 99.1 & 89.7 & 74.4 & 54.0 \\
\hline 12 & 4.29 & 3.21 & 2.99 & 2.74 & 2.66 & 15.3 & 108.8 & 106.7 & 96.1 & 81.7 & 66.2 \\
\hline 15 & 5.00 & 3.47 & 3.19 & 2.90 & 2.72 & 14.9 & 111.5 & 96.0 & 101.5 & 88.4 & 64.5 \\
\hline 18 & 5.29 & 3.93 & 3.54 & 3.03 & 2.80 & 17.2 & 120.0 & 109.3 & 109.2 & 96.8 & 74.5 \\
\hline 21 & 5.40 & 4.56 & 3.80 & 3.21 & 2.87 & 17.8 & 118.1 & 109.2 & 107.1 & 109.4 & 77.1 \\
\hline 24 & 5.56 & 5.04 & 4.32 & 3.35 & 2.99 & 20.3 & 118.8 & 101.8 & 105.5 & 159.5 & 87.9 \\
\hline 28 & 5.75 & 5.36 & 4.77 & 3.60 & 3.08 & 21.7 & 117.6 & 113.0 & 107.5 & 103.6 & 93.9 \\
\hline 33 & 5.90 & 5.58 & 5.18 & 3.89 & 3.30 & 22.3 & 120.0 & 115.2 & 108.3 & 111.9 & 96.4 \\
\hline 38 & 6.01 & 5.72 & 5.32 & 4.39 & 3.41 & 23.2 & 126.2 & 121.9 & 111.7 & 109.1 & 100.4 \\
\hline 44 & 6.12 & 5.86 & 5.56 & 4.88 & 3.70 & 23.7 & 128.9 & 117.6 & 109.0 & 106.1 & 102.5 \\
\hline 50 & 6.16 & 5.92 & 5.68 & 5.18 & 4.03 & 23.5 & 127.1 & 117.7 & 116.6 & 110.5 & 101.7 \\
\hline 57 & 6.26 & 6.01 & 5.77 & 5.37 & 4.33 & 24.1 & 124.2 & 121.1 & 110.8 & 107.7 & 104.5 \\
\hline 65 & 6.35 & 6.18 & 5.89 & 5.56 & 4.72 & 23.7 & 135.9 & 127.4 & 121.8 & 116.5 & 102.6 \\
\hline 75 & 6.45 & 6.25 & 6.02 & 5.72 & 5.17 & 24.2 & 149.9 & 130.9 & 117.2 & 115.0 & 104.8 \\
\hline 85 & 6.49 & 6.35 & 6.09 & 5.89 & 5.48 & 27.9 & 157.4 & 149.2 & 132.2 & 135.5 & 121.0 \\
\hline 100 & 6.58 & 6.45 & 6.19 & 6.01 & 5.67 & 27.6 & 153.2 & 150.4 & 140.3 & 135.6 & 119.5 \\
\hline 120 & 6.64 & 6.60 & 6.38 & 6.21 & 5.97 & 27.8 & 164.0 & 150.3 & 134.5 & 135.1 & 120.4 \\
\hline 145 & 6.79 & 6.72 & 6.53 & 6.41 & 6.19 & 27.2 & 159.0 & 155.2 & 142.1 & 131.1 & 117.8 \\
\hline 173 & 6.84 & 6.81 & 6.69 & 6.59 & 6.42 & 27.2 & 160.0 & 154.7 & 145.3 & 127.8 & 117.9 \\
\hline 240 & 7.04 & 7.05 & 6.92 & 6.90 & 6.81 & 28.6 & 155.4 & 153.1 & 142.2 & 141.6 & 123.8 \\
\hline 315 & 7.31 & 7.30 & 7.21 & 7.28 & 7.38 & 31.8 & 224.2 & 170.3 & 176.9 & 176.6 & 137.6 \\
\hline 485 & 7.46 & 7.53 & 7.50 & 7.59 & 7.73 & 4.3 & $\begin{array}{l}76.7 \\
\end{array}$ & 24.7 & 85.8 & 30.7 & 18.6 \\
\hline
\end{tabular}


Appendix Table 7.1.5 Initial pH 2.0 vs. Particle Sizes

\begin{tabular}{|c|c|c|c|c|c|c|c|c|c|c|c|c|}
\hline & & & $\begin{array}{l}\text { Sample } \\
1\end{array}$ & $\begin{array}{l}\text { Sample } \\
2\end{array}$ & $\begin{array}{l}\text { Sample } \\
3\end{array}$ & $\begin{array}{l}\text { Sample } \\
4\end{array}$ & $\begin{array}{l}\text { Sample } \\
5\end{array}$ & & & & & \\
\hline & & $\begin{array}{l}\text { Particle } \\
\text { Size }\end{array}$ & $\begin{array}{ll}2.0- \\
4.65\end{array}$ & \begin{tabular}{|l|}
$4.75-$ \\
6.3
\end{tabular} & 6.3-11 & \begin{tabular}{|l|}
$11.0-$ \\
19.0
\end{tabular} & $19-25$ & & & & & \\
\hline & & $\begin{array}{l}\text { Weight } \\
(\mathrm{g})\end{array}$ & 100.053 & 100.054 & 100.094 & 100.161 & 100.055 & & & & & \\
\hline & & $\begin{array}{l}\text { Last } \\
\text { Wt. }\end{array}$ & 99.499 & 99.593 & $\begin{array}{r}100.00 \\
5\end{array}$ & 99.776 & 99.653 & \multicolumn{5}{|c|}{$\begin{array}{l}\text { Each beaker filled with } 400 \mathrm{ml} \text { water } \\
\text { solution } \mathrm{pH}=1.974 ; 1.938 .\end{array}$} \\
\hline & & & $\mathrm{pH}$ & $\mathrm{pH}$ & $\mathrm{pH}$ & $\mathrm{pH}$ & $\mathrm{pH}$ & & \multicolumn{3}{|c|}{$\begin{array}{r}\mathrm{Ca} \text { in the solution } \\
\text { without diluted }\end{array}$} & \\
\hline & Time & React t & $2.0-4.65$ & \begin{tabular}{|l|l}
$4.75-6.3$ \\
\end{tabular} & 6.3-11 & $11.0-19.0$ & $19-25$ & $\begin{array}{l}2.0- \\
4.65\end{array}$ & \begin{tabular}{|l|}
$4.75-$ \\
6.3
\end{tabular} & $6.3-11$ & \begin{tabular}{|l|l|}
$11.0-$ & \\
19.0 & \\
\end{tabular} & $19-25$ \\
\hline 1 & $9: 50$ & 0 & 1.93 & 1.94 & 1.92 & 1.93 & 1.93 & 0.0 & 0.0 & 0.0 & \begin{tabular}{|l|}
0.0 \\
\end{tabular} & 0.0 \\
\hline 2 & $9: 51$ & 1 & 2.08 & 1.94 & 1.95 & 1.92 & 1.92 & 206.0 & 318.7 & 140.9 & 70.9 & 57.1 \\
\hline 3 & 54 & 4 & 2.17 & 1.98 & 1.97 & 1.97 & 1.96 & 473.8 & 69.0 & 238.0 & 192.6 & 99.4 \\
\hline 4 & 57 & 7 & 2.41 & 1.99 & 2.24 & 2.10 & 2.00 & 469.4 & 457.6 & 415.6 & 235.7 & 138.7 \\
\hline 5 & $10: 00$ & 10 & 2.80 & 2.29 & 2.48 & 2.17 & 2.06 & 441.9 & 348.1 & 491.4 & 304.1 & 172.4 \\
\hline 6 & $10: 03$ & 13 & 2.63 & 2.51 & 2.66 & 2.28 & 2.10 & 478.3 & 398.5 & 475.9 & 336.5 & 217.5 \\
\hline 7 & 6 & 16 & 3.16 & 3.12 & 2.87 & 2.37 & 2.18 & 536.2 & \begin{tabular}{|c|}
-0.1 \\
\end{tabular} & \begin{tabular}{|l|}
483.3 \\
\end{tabular} & 378.8 & 241.8 \\
\hline 8 & 10 & 20 & 3.41 & 2.78 & 3.02 & 2.51 & 2.22 & 497.0 & 479.0 & 459.3 & 471.0 & 261.5 \\
\hline 9 & 13 & 23 & 4.31 & 3.14 & 3.31 & 2.67 & 2.27 & 549.0 & 545.9 & |554.4 & 436.9 & 320.6 \\
\hline 10 & 17 & 27 & 4.75 & 3.80 & 3.64 & 2.78 & 2.38 & 517.0 & 525.2 & 540.5 & 446.8 & 328.5 \\
\hline 11 & 20 & 30 & 5.10 & 4.57 & 3.99 & 2.90 & 2.45 & 504.3 & 534.7 & 541.3 & 467.0 & 361.1 \\
\hline 12 & 24 & 34 & 5.26 & 5.00 & 4.42 & 3.07 & 2.56 & 523.2 & 520.5 & 549.7 & 553.7 & 393.8 \\
\hline 13 & 28 & 38 & 5.48 & 5.22 & 4.85 & 3.28 & 2.69 & 550.8 & 550.9 & 547.8 & 466.3 & 391.8 \\
\hline 14 & 33 & 43 & 5.58 & 5.38 & 5.03 & 3.50 & 2.81 & 515.2 & 527.2 & 510.0 & 456.0 & 411.7 \\
\hline 15 & 37 & 47 & 5.67 & 5.47 & 5.19 & 3.69 & 2.94 & 591.3 & 601.4 & 584.7 & 539.5 & 474.7 \\
\hline 16 & 40 & 50 & 5.71 & 5.58 & 5.28 & 3.90 & 3.06 & 606.4 & 589.5 & 578.4 & 538.3 & 462.8 \\
\hline 17 & 45 & 55 & 5.79 & 5.65 & 5.38 & 4.19 & 3.24 & 587.6 & 565.0 & 2.0 & 499.9 & 494.2 \\
\hline 18 & 50 & 60 & 5.86 & \begin{tabular}{|l|}
5.71 \\
\end{tabular} & 5.46 & 4.62 & 3.41 & 561.0 & \begin{tabular}{|l|}
584.3 \\
\end{tabular} & \begin{tabular}{|l|}
838.3 \\
\end{tabular} & 503.8 & 483.2 \\
\hline 19 & 55 & 65 & 5.90 & 5.78 & 5.52 & 4.82 & 3.53 & 568.2 & 593.4 & 569.3 & 514.2 & 511.3 \\
\hline 20 & $11: 00$ & 70 & 5.95 & 5.82 & 5.58 & 4.99 & 3.72 & 584.2 & 644.6 & |578.9 & \begin{tabular}{|l|}
532.3 \\
\end{tabular} & 488.1 \\
\hline 21 & 8 & 78 & 6.02 & 5.91 & 5.67 & 5.17 & 4.12 & 651.2 & 662.0 & 572.7 & 528.4 & 477.3 \\
\hline 22 & 17 & 87 & 6.07 & 5.96 & 5.73 & 5.30 & 4.51 & 581.9 & 620.0 & 582.6 & 499.8 & 482.6 \\
\hline 23 & 25 & 95 & 6.13 & 6.01 & 5.81 & 5.42 & 4.88 & 576.1 & \begin{tabular}{|l|}
593.3 \\
\end{tabular} & \begin{tabular}{|l|}
574.3 \\
\end{tabular} & \begin{tabular}{|c|}
495.3 \\
\end{tabular} & 486.9 \\
\hline 24 & 36 & 106 & 6.18 & 6.09 & 5.88 & 5.56 & 5.21 & 614.1 & 663.8 & 623.8 & 533.0 & 523.3 \\
\hline 25 & 50 & 120 & 6.26 & 6.15 & 5.96 & 5.67 & 5.40 & 667.0 & 665.5 & 614.4 & 549.9 & 510.9 \\
\hline 26 & $12: 10$ & 140 & 6.33 & 6.21 & 6.07 & 5.81 & 5.68 & 610.5 & 650.9 & 654.5 & 589.5 & 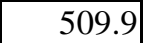 \\
\hline 27 & 35 & 165 & 6.40 & 6.31 & 6.17 & 5.93 & 5.89 & 619.1 & 666.8 & 625.1 & 568.7 & 499.6 \\
\hline 28 & 13:05 & 195 & 6.47 & 6.36 & 6.27 & 6.14 & 6.17 & 629.7 & 684.7 & 588.1 & 569.0 & 513.5 \\
\hline 29 & 40 & 230 & 6.53 & 6.46 & 6.39 & 6.30 & 6.39 & 660.4 & 678.5 & 665.7 & 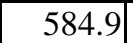 & 519.7 \\
\hline 30 & $14: 30$ & 280 & 6.69 & 6.55 & 6.54 & 6.52 & 6.54 & 650.1 & 693.7 & 630.5 & 559.9 & 538.4 \\
\hline 31 & $16: 50$ & 420 & 7.01 & 6.78 & 6.84 & 7.07 & 6.83 & 642.4 & 639.4 & 620.9 & 579.7 & 520.5 \\
\hline
\end{tabular}


Appendix Table 7.1.6 Limestone Surface Area Experiment

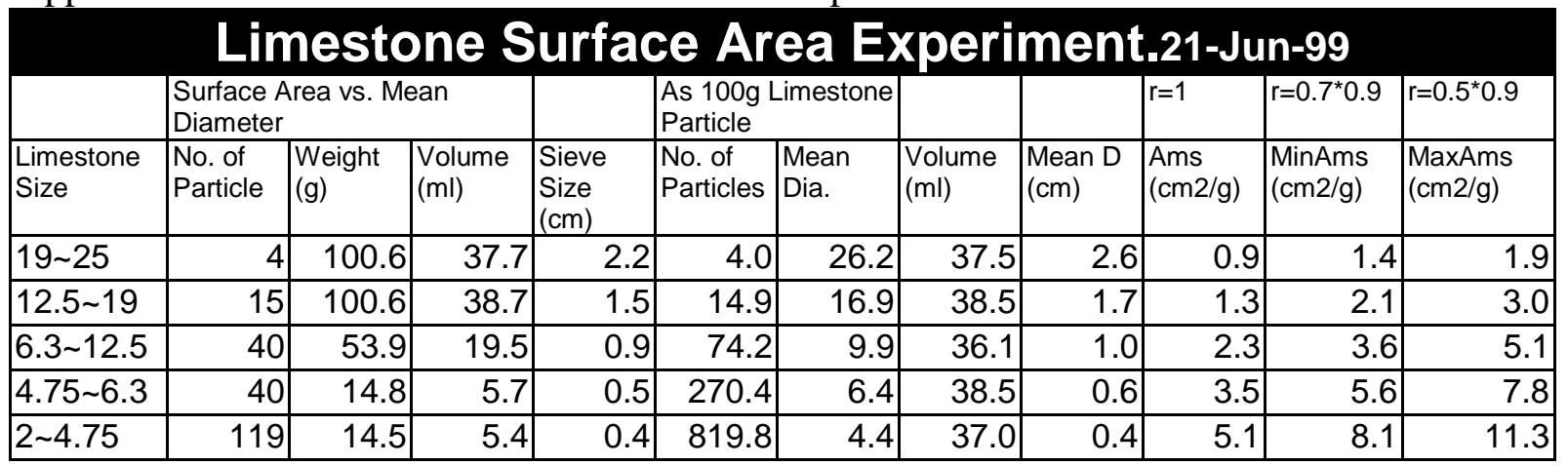


Appendix Table 7.1.7 Destination pH 5.5, 6.0, 6.5, 7.0 vs. time of different sizes

\begin{tabular}{|c|c|c|c|c|c|c|c|c|c|c|c|c|}
\hline & & & & & Destinati & ion $\mathrm{pH}=5$ & & & & & & $=a^{*} A m s^{\wedge} k$ \\
\hline & \begin{tabular}{|l}
$\#$ \\
Particle
\end{tabular} & $A_{M S}$ & Size $(\mathrm{mm}$ & $\operatorname{lgAms}$ & $\mathrm{pHi}=2.0$ & $\mathrm{pHi}=2.5$ & $\mathrm{pHi}=3.0$ & $\mathrm{pHi}=3.5$ & $\mathrm{pHi}=4.0$ & $\mathrm{pHi}$ & $\mathrm{a}$ & $k^{*}(-100)$ \\
\hline $2 \sim 4.75$ & 820 & 9.7 & 4.44 & 0.99 & 40 & 23 & 14 & 8 & 3 & 2 & 183.2 & 68.1 \\
\hline $4.75 \sim 6.3$ & 270 & 6.7 & 6.42 & 0.82 & 48 & 30 & 16 & 10 & 4.5 & 2.5 & 125.7 & 75.8 \\
\hline $6.3 \sim 11$ & 74 & 4.3 & 9.88 & 0.64 & 65 & 40 & 21 & 15 & 5.5 & 3 & 94.2 & 89.3 \\
\hline $11 \sim 19$ & 15 & 2.5 & 16.88 & 0.40 & 100 & 60 & 50 & 25 & 6 & 3.5 & 62.6 & 94.1 \\
\hline \begin{tabular}{|l|}
$19 \sim 25$ \\
\end{tabular} & 4 & 1.6 & 26.22 & 0.21 & 130 & 90 & 58 & 42 & 17 & 4 & 19.2 & 82.8 \\
\hline & & & & & \multicolumn{3}{|c|}{ Destination $\mathrm{pH} 6.0$} & & & \multicolumn{3}{|c|}{$\mathrm{t}=\mathrm{a}^{*} \mathrm{e}^{\wedge}\left(\mathrm{k}^{*} \log [\mathrm{Ams}]\right)$} \\
\hline & \begin{tabular}{|l}
$\#$ \\
Particle \\
\end{tabular} & $A_{M S}$ & \begin{tabular}{|l|} 
Size $(\mathrm{mm}$ \\
.
\end{tabular} & & $\mathrm{pHi}=2.0$ & $\mathrm{pHi}=2.5$ & $\mathrm{pHi}=3.0$ & $\mathrm{pHi}=3.5$ & $\mathrm{pHi}=4.0$ & $\mathrm{pHi}$ & $\mathrm{a}$ & $\mathrm{k}$ \\
\hline $2 \sim 4.75$ & 820 & 9.7 & 4.4 & & 77 & 37 & 22 & 13 & 4 & 2 & 256.15 & -0.51 \\
\hline $4.75 \sim 6.3$ & 270 & 6.7 & 6.4 & & 93 & 55 & 24 & 15 & 7 & 2.5 & 178.74 & -0.65 \\
\hline $6.3 \sim 11$ & 74 & 4.3 & 9.9 & & 130 & 75 & 43 & 20 & 8 & 3 & 108.38 & -0.72 \\
\hline $11 \sim 19$ & 15 & 2.5 & 16.9 & & 175 & 95 & 54 & 33 & 10 & 3.5 & 71.11 & -0.79 \\
\hline 19 25 & 4 & 1.6 & 26.2 & & 180 & 125 & 75 & 52 & 22 & 4 & 27.91 & -0.83 \\
\hline & & & & & \multicolumn{3}{|c|}{ Destination $\mathrm{pH}=6.5$} & & & & & \\
\hline & \begin{tabular}{|l}
$\#$ \\
Particle
\end{tabular} & $A_{M S}$ & Size $(\mathrm{mm}$ & & $\mathrm{pHi}=2.0$ & $\mathrm{pHi}=2.5$ & $\mathrm{pHi}=3.0$ & $\mathrm{pHi}=3.5$ & $\mathrm{pHi}=4.0$ & $\mathrm{pHi}$ & $a$ & $k$ \\
\hline $2 \sim 4.75$ & 820 & 9.7 & 4.4 & & 220 & 90 & 37 & 24 & 7 & 2 & 281.12 & -0.10 \\
\hline $4.75 \sim 6.3$ & 270 & 6.7 & 6.4 & & 255 & 110 & 44 & 26 & 9 & 2.5 & 273.89 & -0.41 \\
\hline $6.3 \sim 11$ & 74 & 4.3 & 9.9 & & 255 & 140 & 58 & 31 & 12 & 3 & 142.26 & -0.60 \\
\hline $11 \sim 19$ & 15 & 2.5 & 16.9 & & 265 & 160 & 83 & 47 & 14 & 3.5 & 91.32 & -0.64 \\
\hline 19 25 & 4 & 1.6 & 26.2 & & 270 & 190 & 105 & 75 & 24 & 4 & 29.76 & -0.64 \\
\hline & & & & & \multicolumn{3}{|c|}{ Destination $\mathrm{pH} 7.0$} & & & & & \\
\hline & $\begin{array}{l}\# \\
\text { Particle }\end{array}$ & $A_{M S}$ & Size $(\mathrm{mm}$ & & $\mathrm{pHi}=2.0$ & $\mathrm{pHi}=2.5$ & $\mathrm{pHi}=3.0$ & $\mathrm{pHi}=3.5$ & $\mathrm{pHi}=4.0$ & $\mathrm{pHi}$ & $a$ & $k$ \\
\hline $2 \sim 4.75$ & 820 & 9.7 & 4.4 & & 400 & 240 & 75 & 36 & 11 & 2 & 443.62 & -0.04 \\
\hline $4.75 \sim 6.3$ & 270 & 6.7 & 6.4 & & 410 & 240 & 84 & 37 & 15 & 2.5 & 278.06 & -0.07 \\
\hline $6.3 \sim 11$ & 74 & 4.3 & 9.9 & & 420 & 250 & 95 & 45 & 16 & 3 & 184.21 & -0.41 \\
\hline $11 \sim 19$ & 15 & 2.5 & 16.9 & & 415 & 260 & 125 & 70 & 17 & 3.5 & 123.93 & -0.60 \\
\hline 19 25 & 4 & 1.6 & 26.2 & & 440 & 270 & 155 & 100 & 30 & 4 & 32.57 & -0.47 \\
\hline
\end{tabular}




\section{Appendix Figures 7.1.1 16}

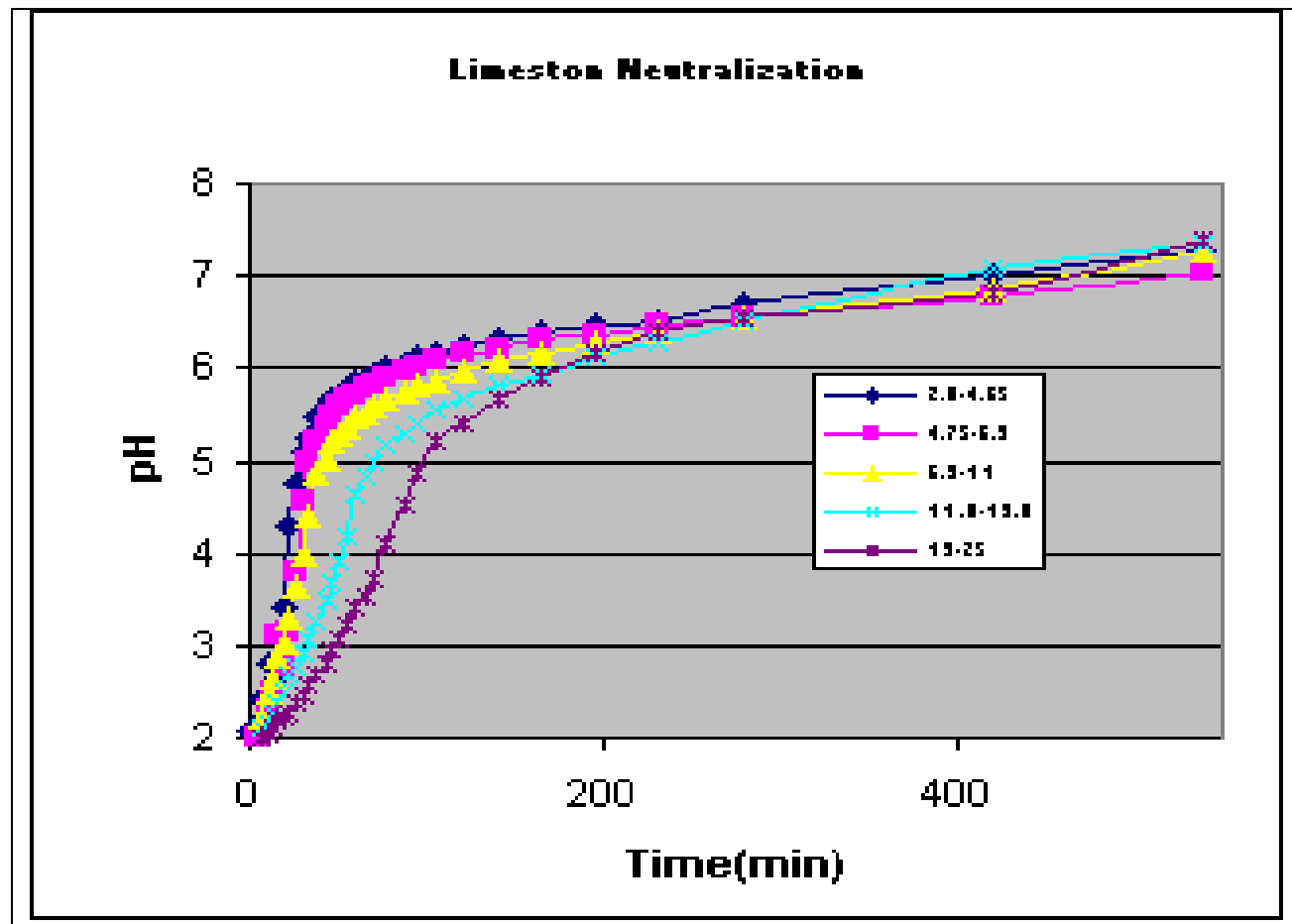

Appendix Figures 7.1.1 pH in proton acid solution $\left(\mathrm{pH}_{\mathrm{i}}=2.0\right)$ with ellipsoid limestone particles.

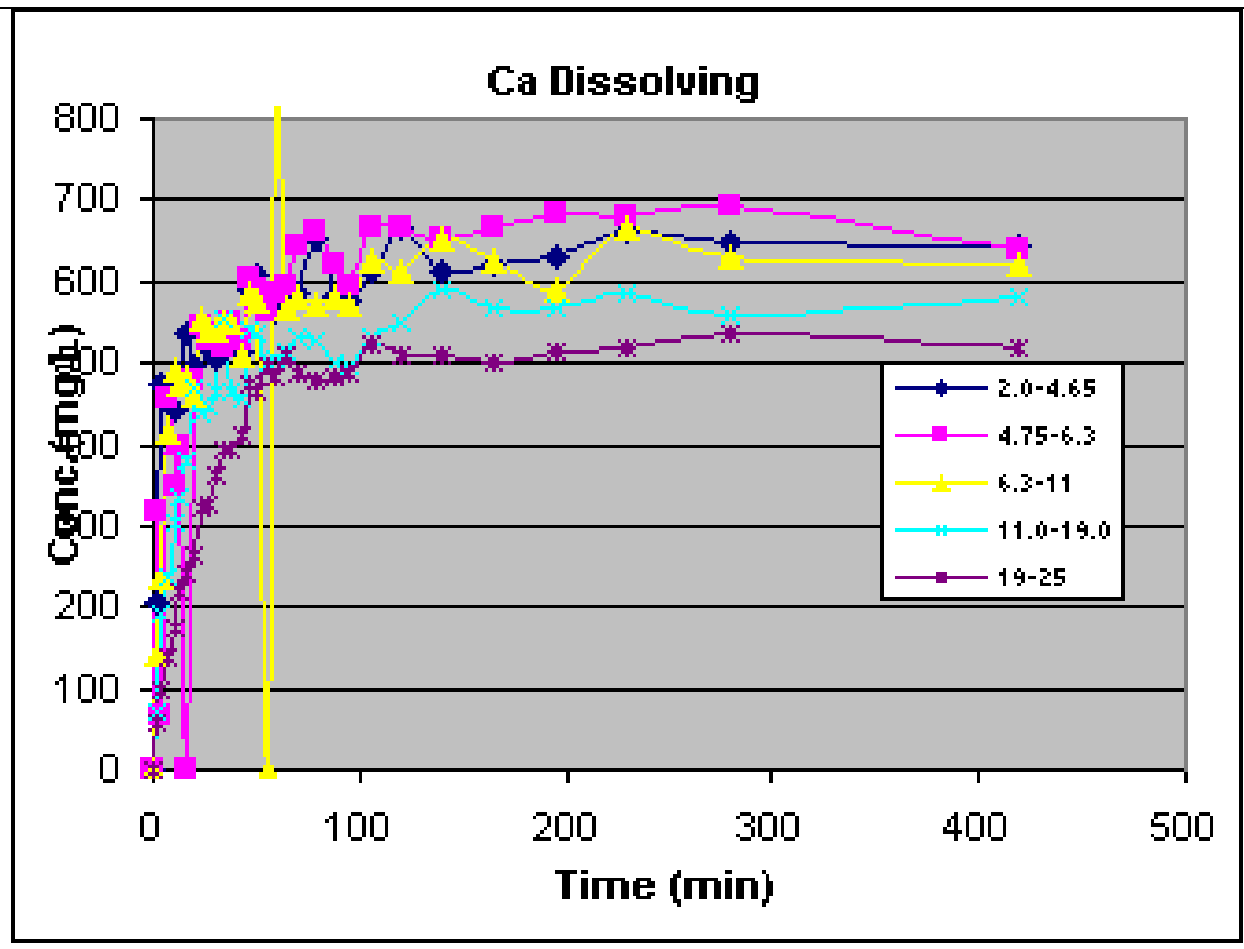

Appendix Figures 7.1.2 $\mathrm{Ca}$ in proton acid solution $\left(\mathrm{pH}_{\mathrm{i}}=2.0\right)$ with ellipsoid limestone particles. 


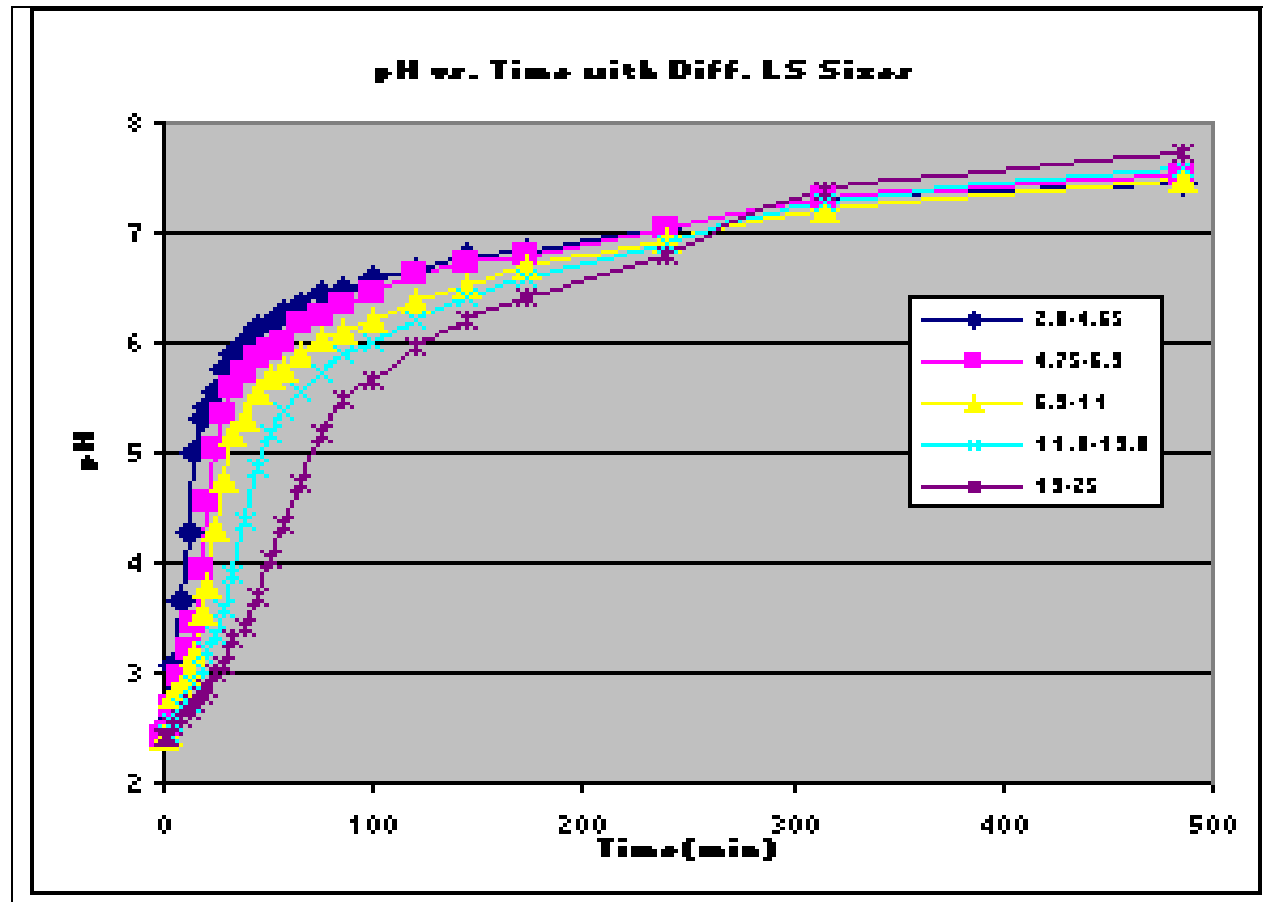

Appendix Figures 7.1.3 $\mathrm{pH}$ in proton acid solution $\left(\mathrm{pH}_{\mathrm{i}}=2.5\right)$ with ellipsoid limestone particles.

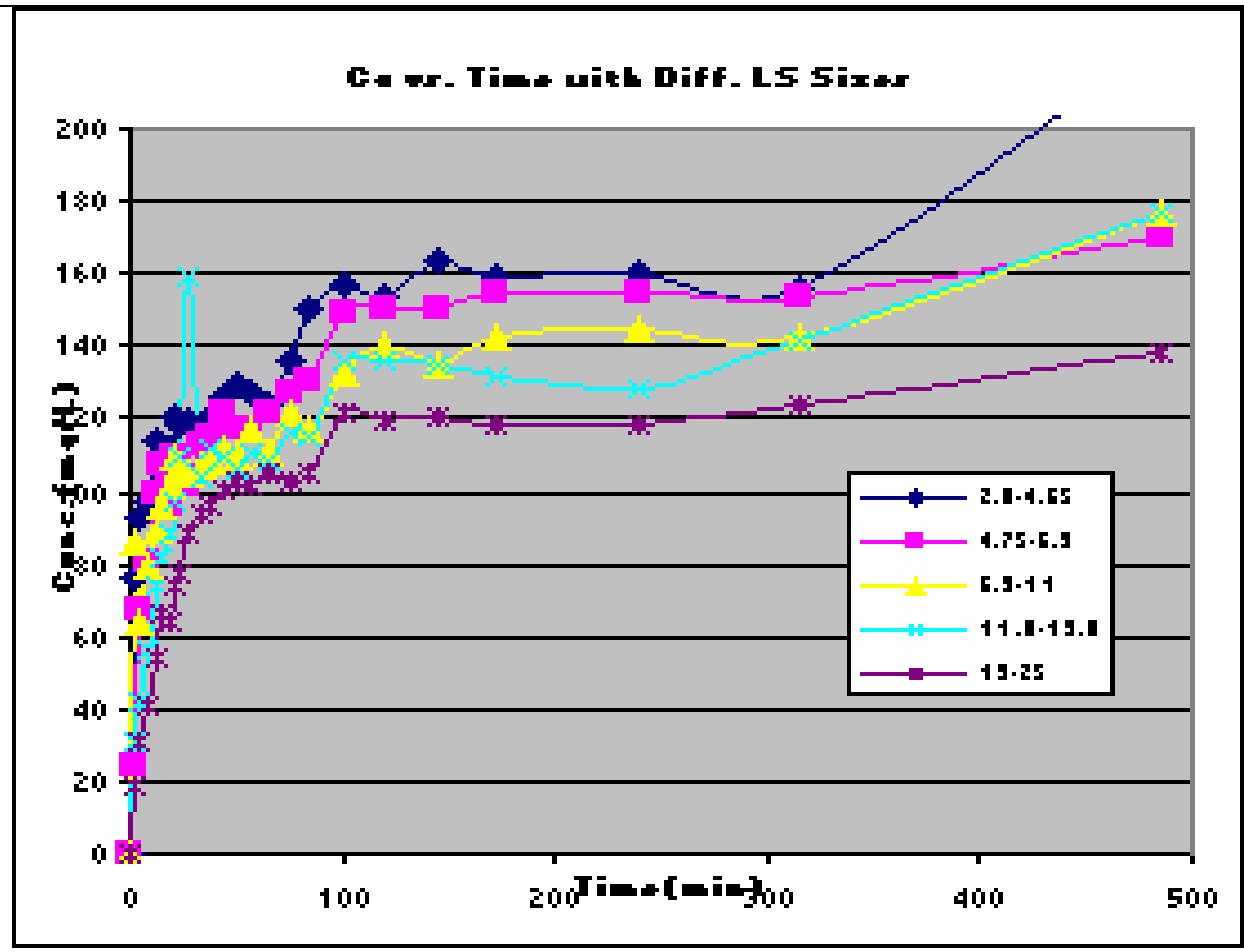

Appendix Figures 7.1.4 $\mathrm{Ca}$ in proton acid solution $\left(\mathrm{pH}_{\mathrm{i}}=2.5\right)$ with ellipsoid limestone particles. 


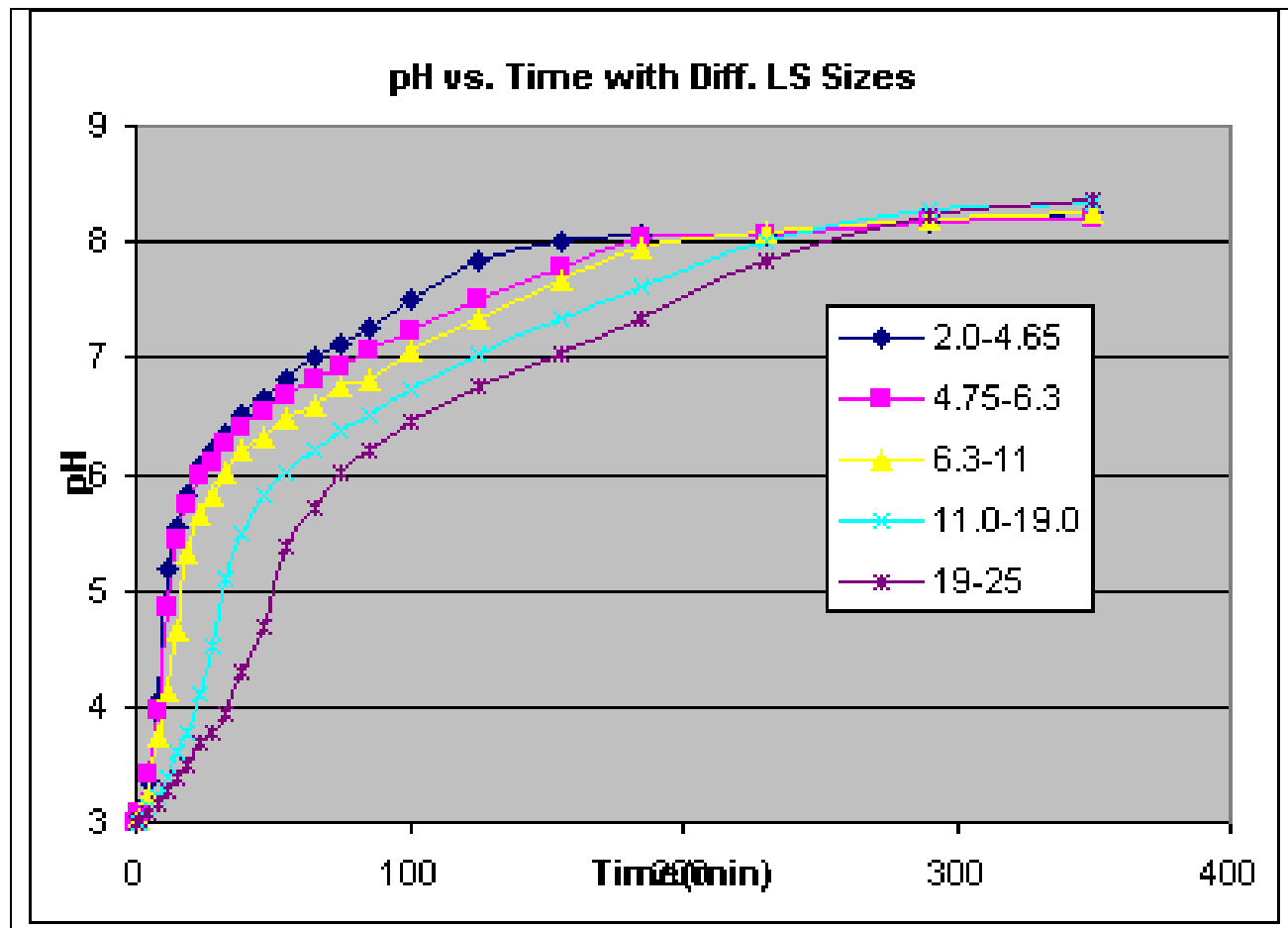

Appendix Figures 7.1.5 $\mathrm{pH}$ in proton acid solution $\left(\mathrm{pH}_{\mathrm{i}}=3.0\right)$ with ellipsoid limestone particles.

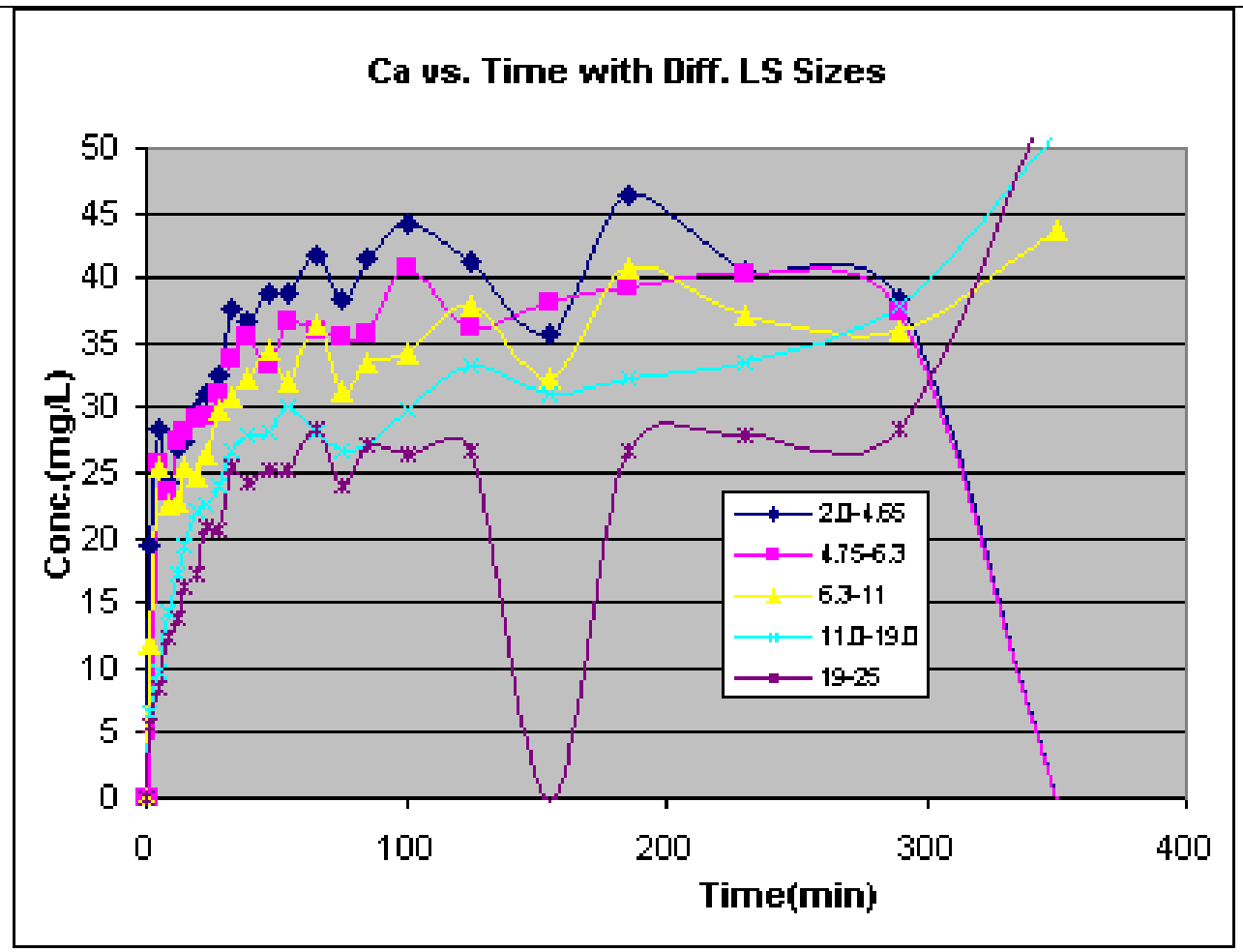

Appendix Figures 7.1.6 $\mathrm{Ca}$ in proton acid solution $\left(\mathrm{pH}_{\mathrm{i}}=3.0\right)$ with ellipsoid limestone particles. 


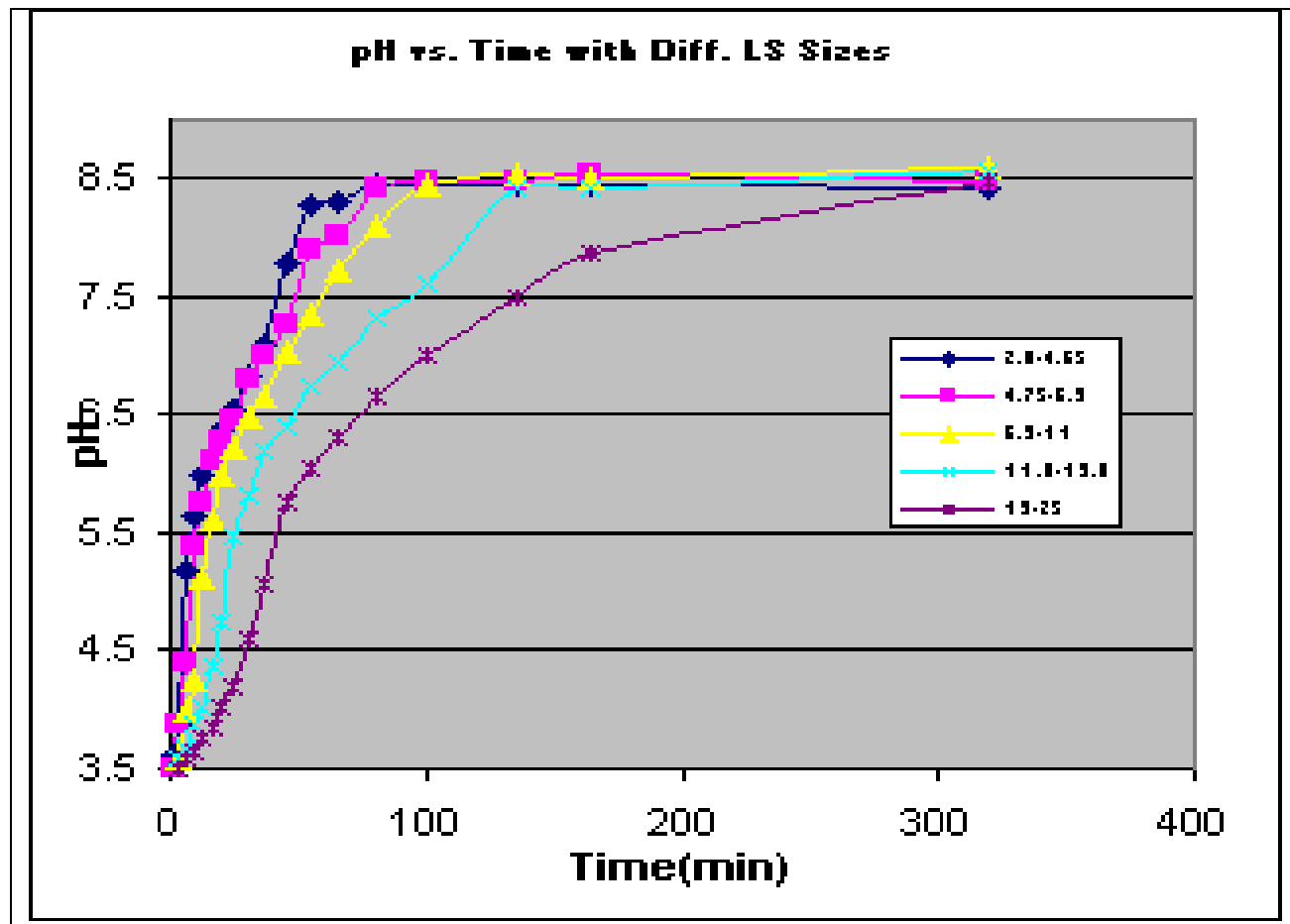

Appendix Figures 7.1.7 $\mathrm{pH}$ in proton acid solution $\left(\mathrm{pH}_{\mathrm{i}}=3.5\right)$ with ellipsoid limestone particles.

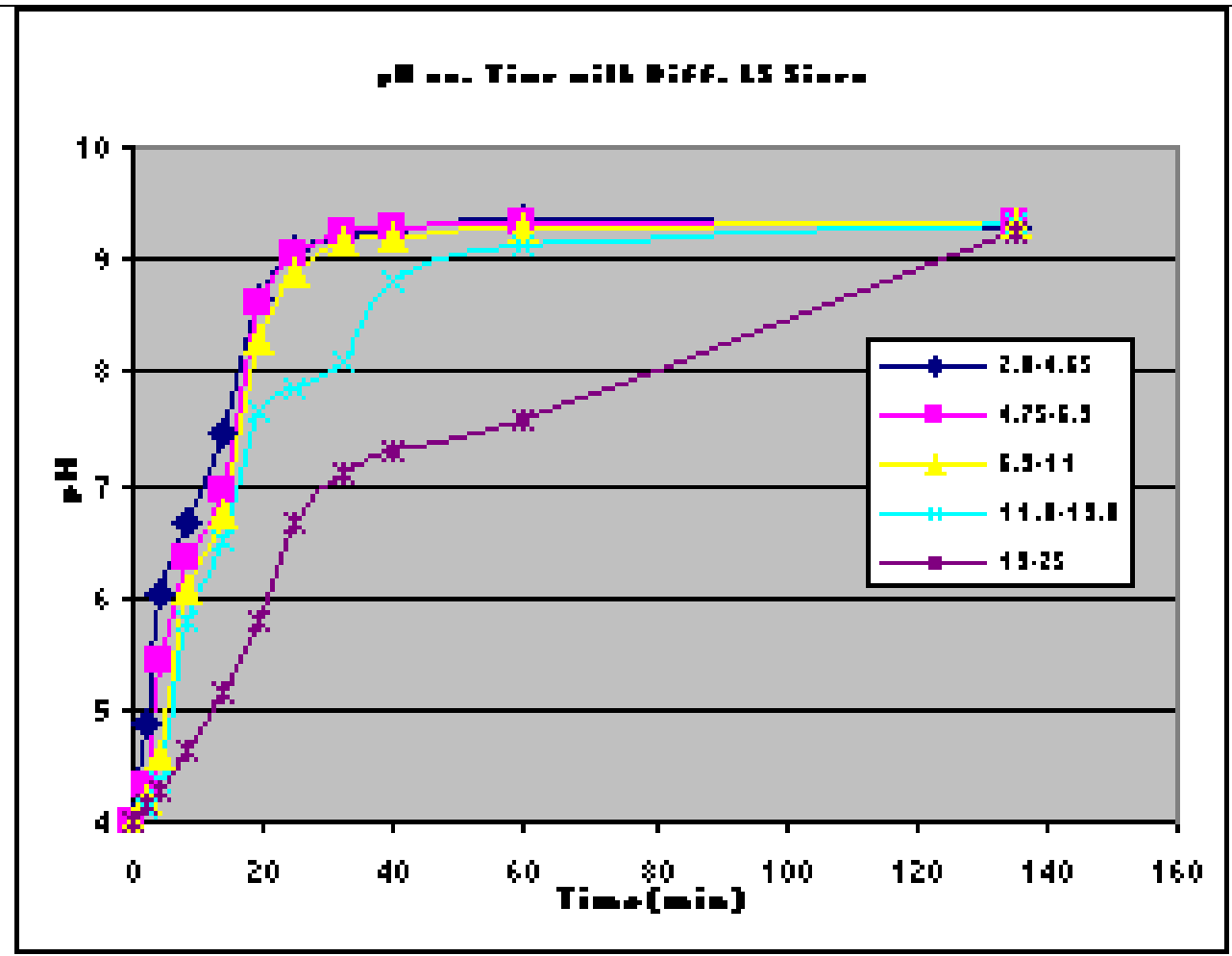

Appendix Figures 7.1.8 $\mathrm{pH}$ in proton acid solution $\left(\mathrm{pH}_{\mathrm{i}}=4.0\right)$ with ellipsoid limestone particles. 


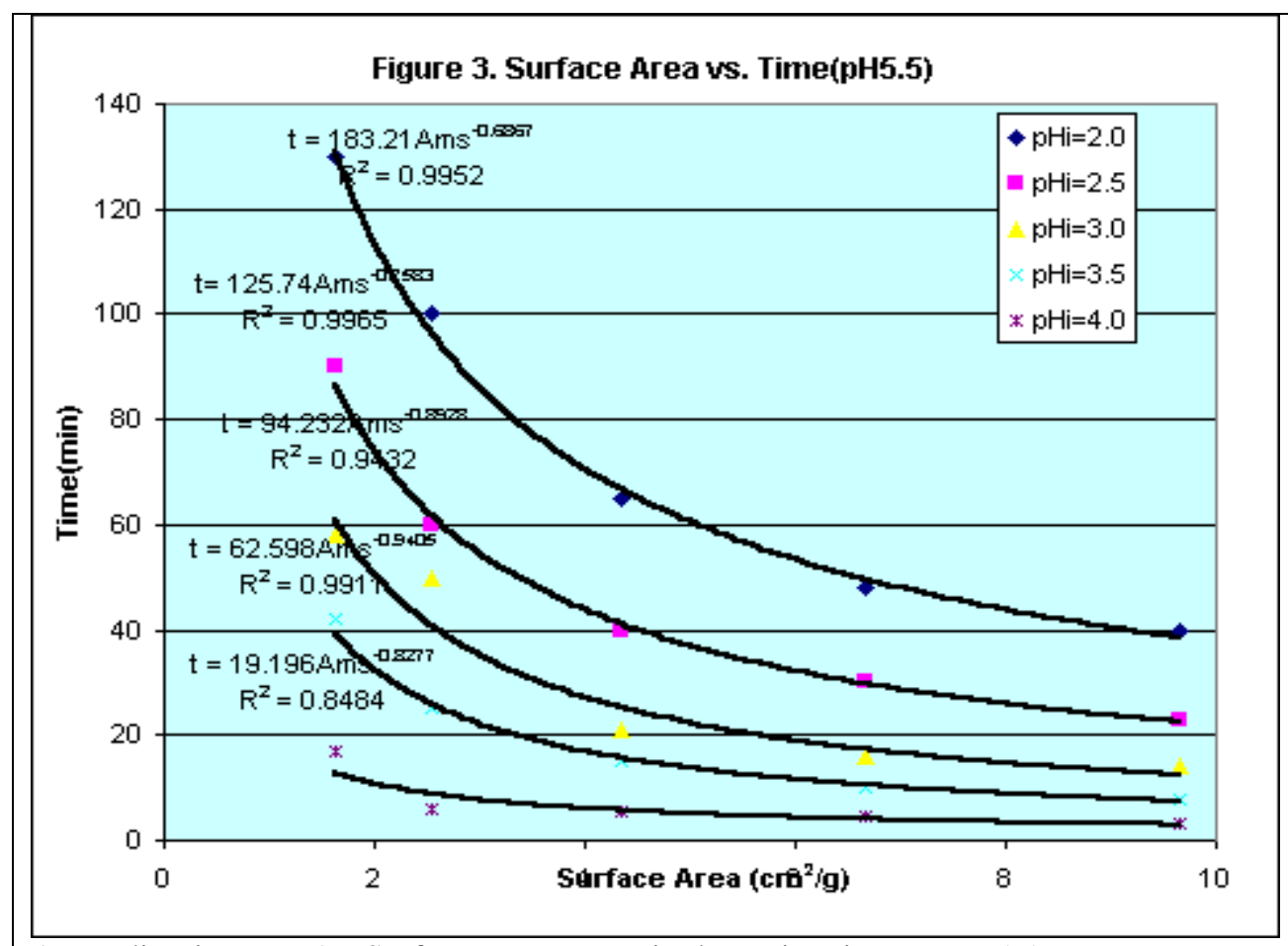

Appendix Figures 7.1.9 Surface area vs. required reaction time at $\mathrm{pH}_{\mathrm{f}}$ 5.5.

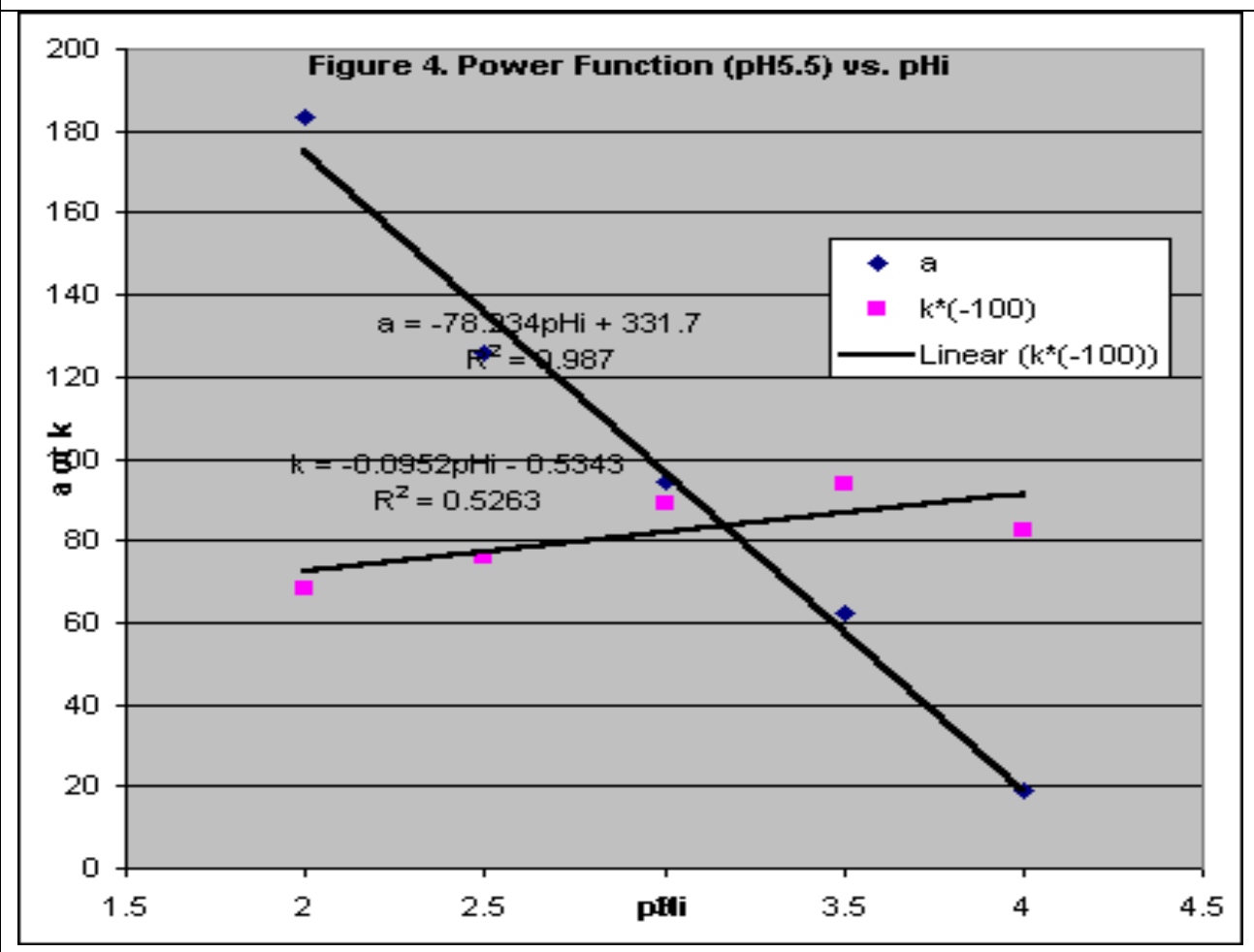

Appendix Figures 7.1.10 a and $\mathrm{k}$ vs. $\mathrm{pH}_{\mathrm{i}}$ at $\mathrm{pH}_{\mathrm{f}}$ 5.5. 


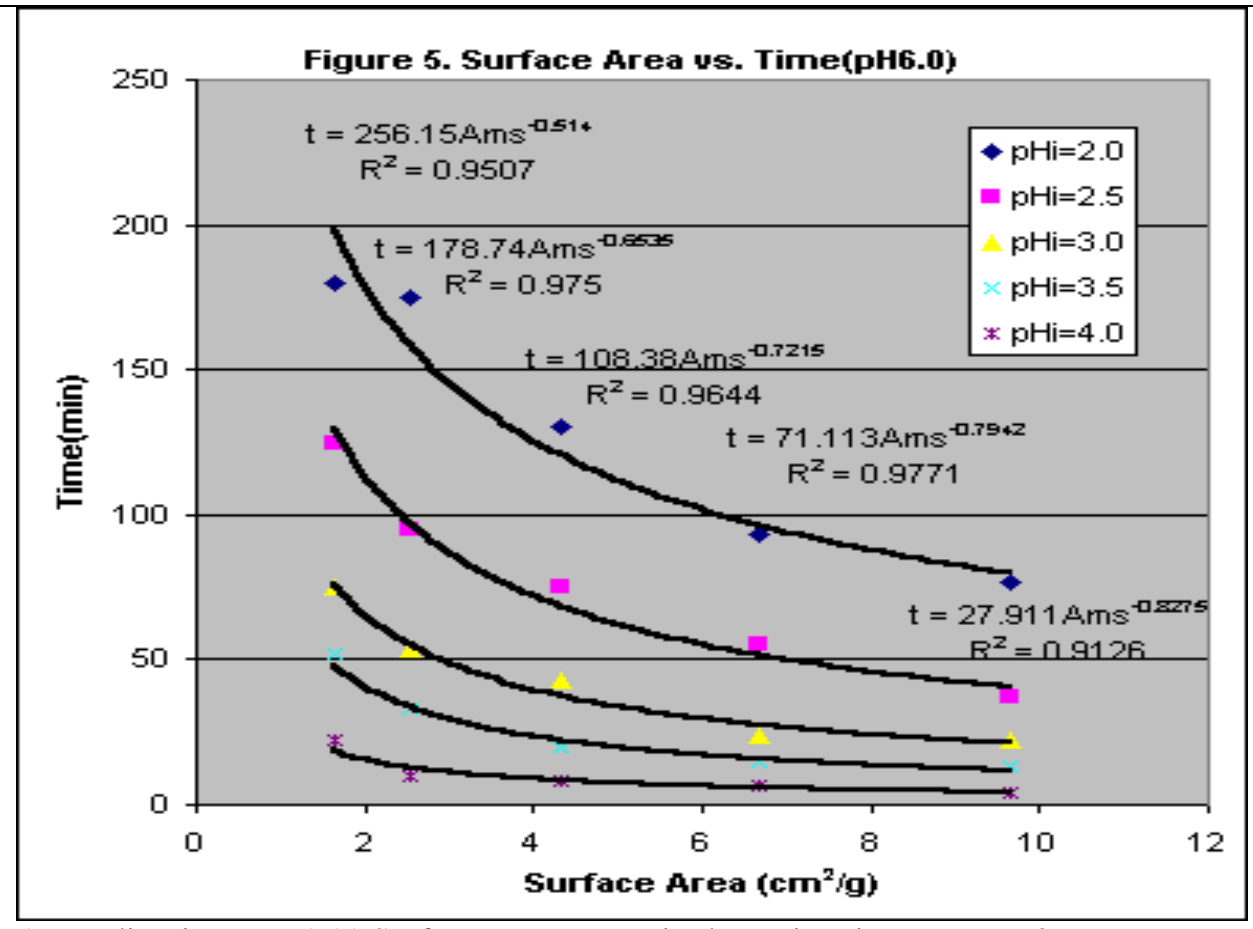

Appendix Figures 7.1.11 Surface area vs. required reaction time at $\mathrm{pH}_{\mathrm{f}} 6.0$.

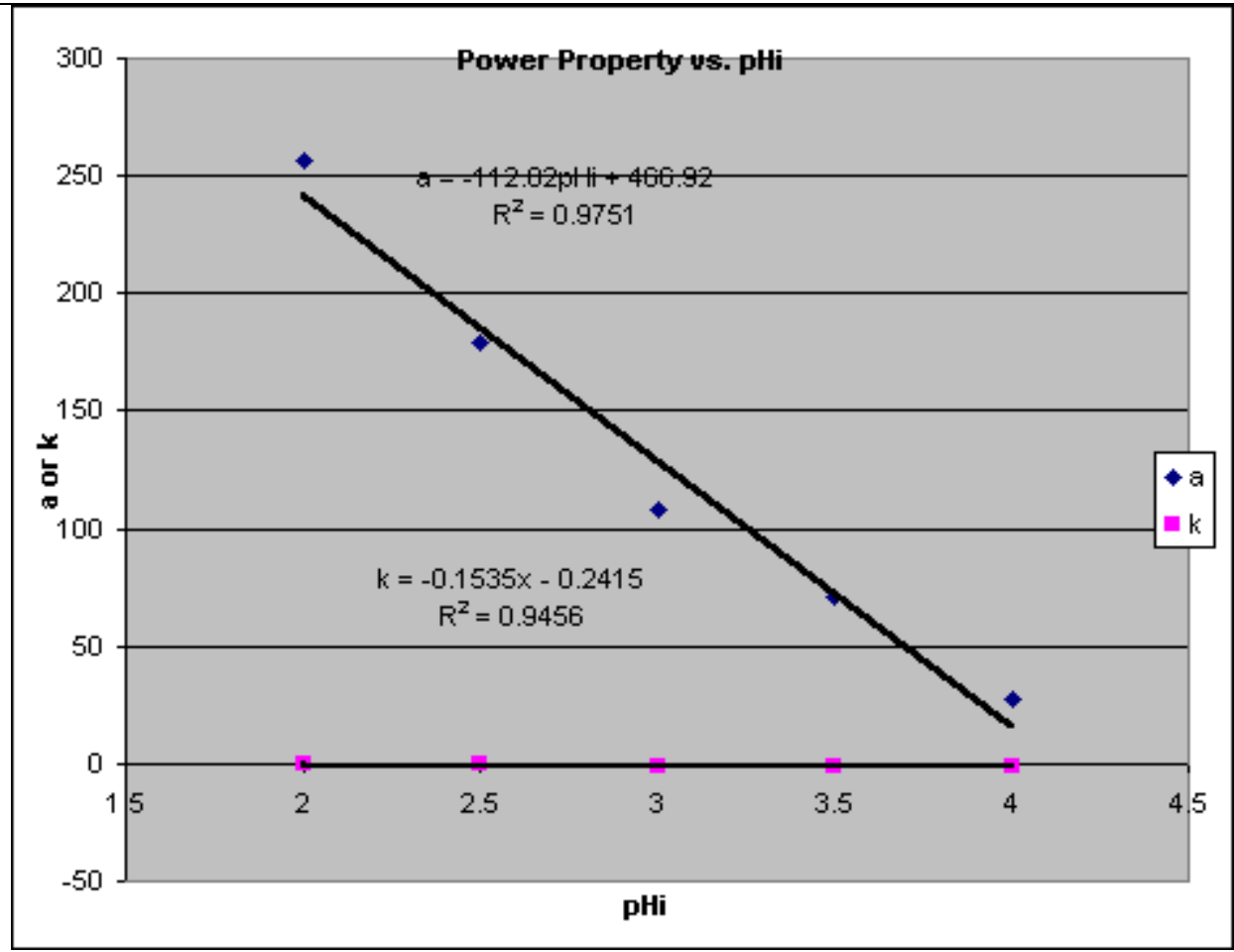

Appendix Figures 7.1.12 a and k vs. $\mathrm{pH}_{\mathrm{i}}$ at $\mathrm{pH}_{\mathrm{f}}$ 6.0. 


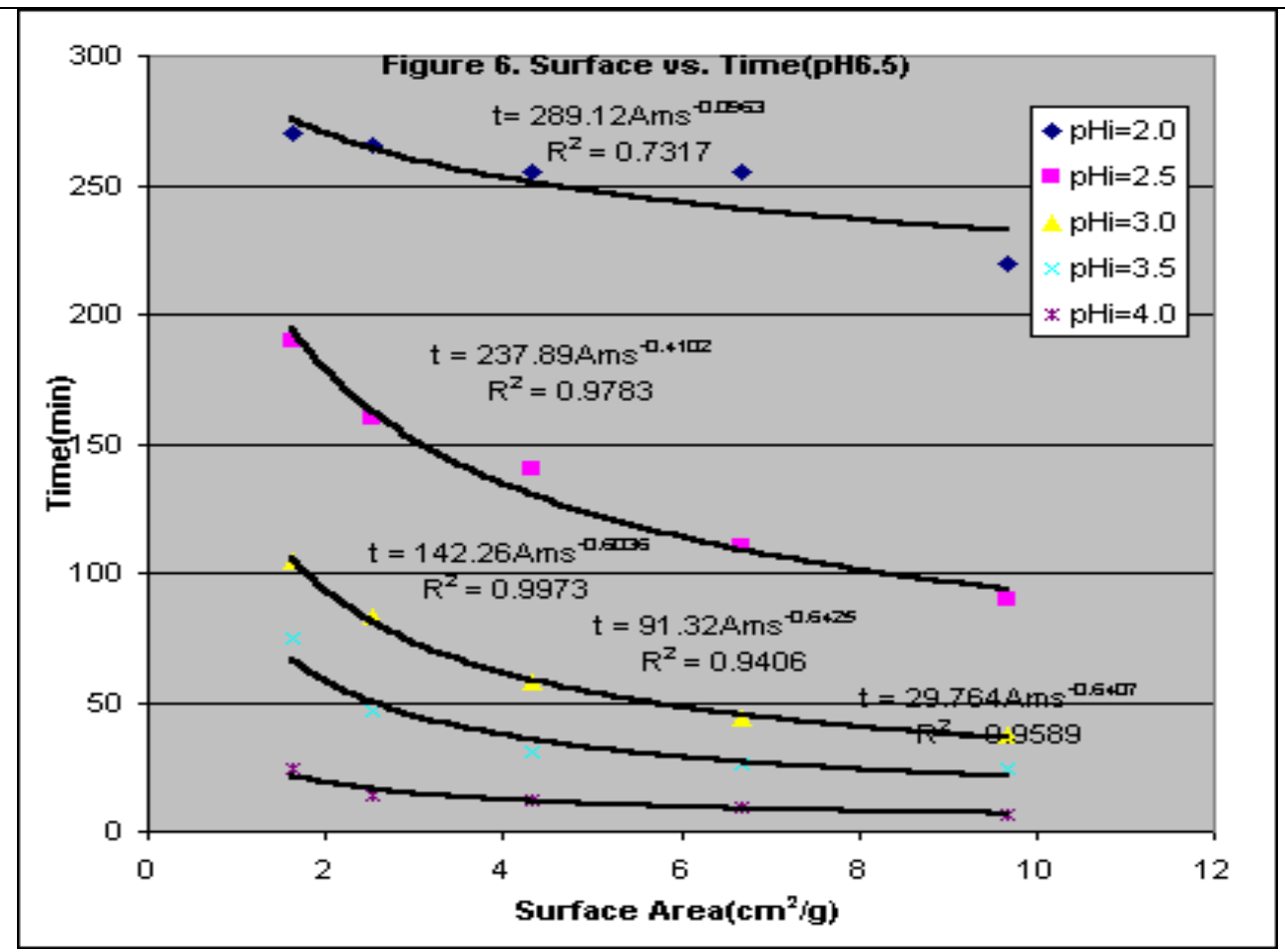

Appendix Figures 7.1.13 Surface area vs. required reaction time at $\mathrm{pH}_{\mathrm{f}}$ 6.5.

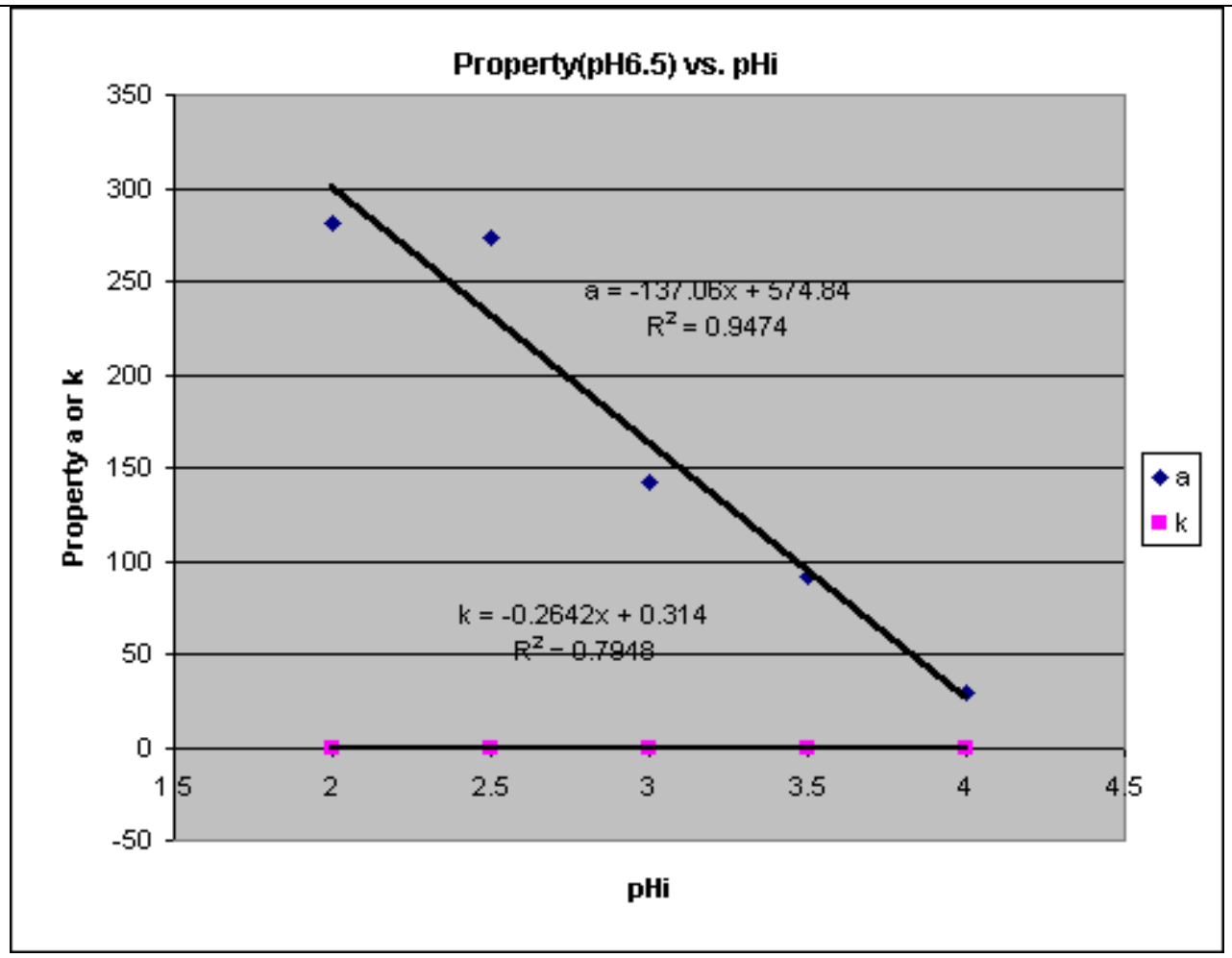

Appendix Figures 7.1.14 a and $\mathrm{k}$ vs. $\mathrm{pH}_{\mathrm{i}}$ at $\mathrm{pH}_{\mathrm{f}}$ 6.5. 


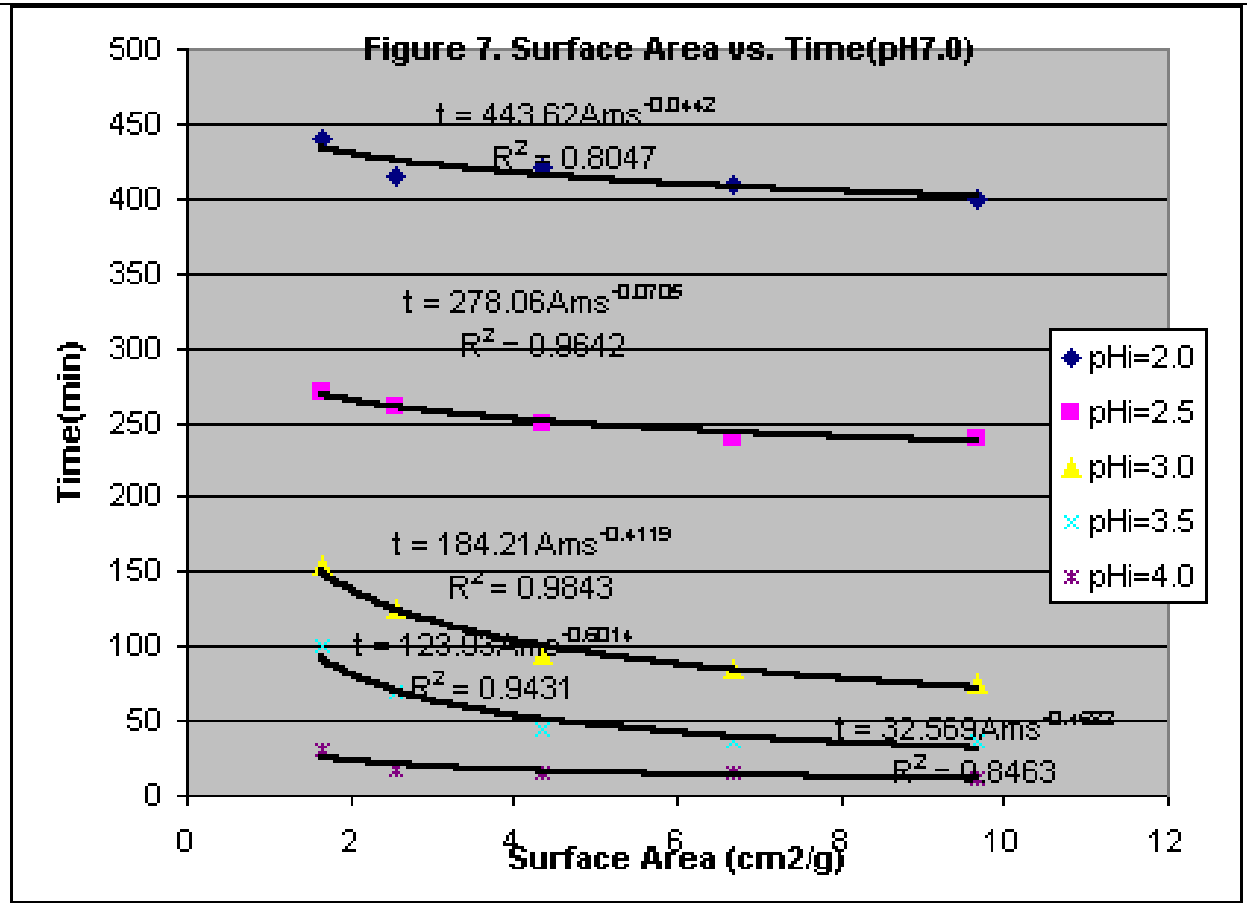

Appendix Figures 7.1.15 Surface area vs. required reaction time at $\mathrm{pH}_{\mathrm{f}}$ 7.0.

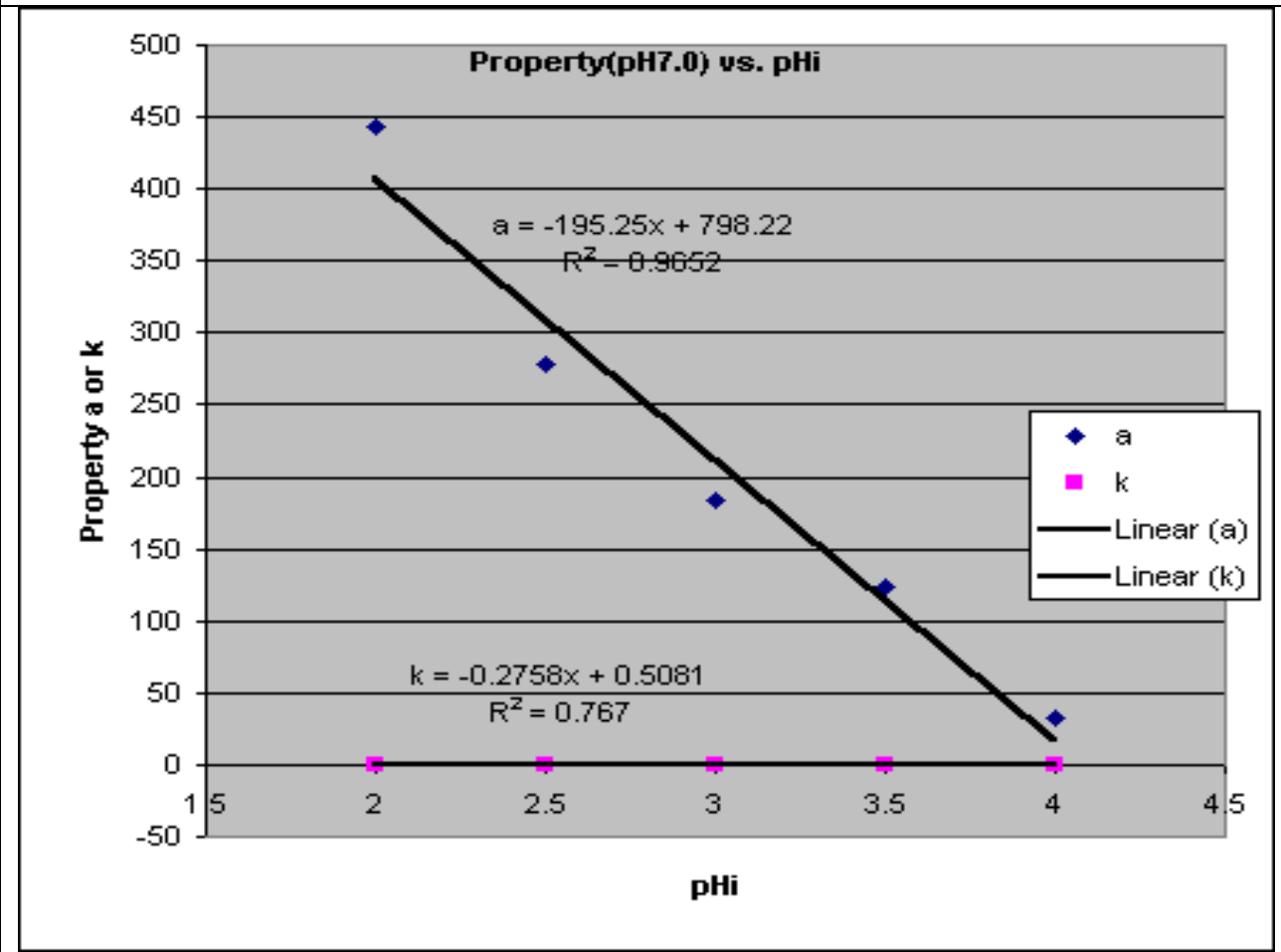

Appendix Figures 7.1.16 a and k vs. $\mathrm{pH}_{\mathrm{i}}$ at $\mathrm{pH}_{\mathrm{f}}$ 7.0. 
Appendix Table 7.2.1 $\mathrm{pH}$ changes with the neutralization of acid solution by limestone chips.

\begin{tabular}{|c|c|c|c|c|c|c|c|c|c|c|}
\hline & & \multicolumn{4}{|c|}{ pH vs. time } & \multicolumn{5}{|c|}{$\begin{array}{l}\text { Proton acid by } 6.3 \sim 11 \mathrm{~mm} \\
\text { crushed limestone chips }\end{array}$} \\
\hline & & & & & & & & & & \\
\hline Time & $\mathrm{pH} 1.75$ & $\mathrm{pH} 2.0$ & pH2.25 & $\mathrm{pH} 2.5$ & $\mathrm{pH} 2.75$ & $\mathrm{pH} 3.0$ & $\mathrm{pH} 3.25$ & $\mathrm{pH} 3.5$ & pH3.75 & $\mathrm{pH} 4.0$ \\
\hline 0 & 1.76 & 2.00 & 2.27 & 2.51 & 2.80 & 3.05 & 3.28 & 3.58 & 3.85 & 4.19 \\
\hline 0.5 & 1.77 & 2.01 & 2.91 & 2.53 & 2.83 & 3.15 & 3.33 & 3.61 & 4.20 & 4.87 \\
\hline 1 & 1.78 & 2.02 & 2.32 & 2.54 & 2.92 & 3.21 & 3.40 & 3.70 & 4.52 & 5.22 \\
\hline 1.5 & 1.81 & 2.06 & 2.37 & 2.56 & 2.93 & 3.30 & 3.43 & 3.80 & 4.93 & 5.89 \\
\hline 2 & 1.85 & 2.11 & 2.45 & 2.59 & 3.09 & 3.38 & 3.52 & 3.91 & 5.29 & 6.11 \\
\hline 2.5 & 1.92 & 2.17 & 2.54 & 2.62 & 3.13 & 3.48 & 3.62 & 4.05 & 5.54 & 6.30 \\
\hline 3 & 1.98 & 2.25 & 2.59 & 2.66 & 3.26 & 3.55 & 3.73 & 4.18 & 5.71 & 6.45 \\
\hline 3.5 & 2.01 & 2.36 & 2.68 & 2.70 & 3.33 & 3.66 & 3.81 & 4.39 & 5.85 & 6.51 \\
\hline 4 & 2.09 & 2.47 & 2.80 & 2.77 & 3.51 & 3.78 & 3.92 & 4.60 & 5.94 & 6.67 \\
\hline 4.5 & 2.16 & 2.52 & 2.86 & 2.84 & 3.61 & 3.89 & 4.07 & 4.79 & 6.03 & 6.83 \\
\hline 5 & 2.23 & 2.60 & 2.94 & 2.90 & 3.73 & 4.03 & 4.27 & 4.94 & 6.12 & 7.01 \\
\hline 6 & 2.40 & 2.74 & 3.13 & 3.04 & 4.02 & 4.36 & 4.55 & 5.17 & 6.28 & 7.48 \\
\hline 7 & 2.57 & 2.91 & 3.32 & 3.21 & 4.35 & 4.69 & 4.75 & 5.39 & 6.44 & 7.98 \\
\hline 8 & 2.76 & 3.06 & 3.53 & 3.40 & 4.63 & 4.94 & 4.94 & 5.54 & 6.58 & 8.44 \\
\hline 9 & 2.90 & 3.26 & 3.76 & 3.68 & 4.91 & 5.16 & 5.08 & 5.64 & 6.71 & 8.76 \\
\hline 10 & 3.11 & 3.44 & 4.01 & 3.94 & 5.09 & 5.31 & 5.20 & 5.75 & 6.88 & 8.96 \\
\hline 12 & 3.55 & 3.89 & 4.56 & 4.41 & 5.33 & 5.55 & 5.36 & 5.91 & 7.24 & 9.20 \\
\hline 14 & 4.09 & 4.39 & 4.92 & 4.66 & 5.51 & 5.71 & 5.49 & 6.06 & 7.70 & 9.22 \\
\hline 16 & 4.49 & 4.74 & 5.13 & 4.84 & 5.63 & 5.83 & 5.60 & 6.17 & 7.95 & 9.29 \\
\hline 18 & 4.75 & 4.95 & 5.27 & 4.96 & 5.74 & 5.94 & 5.71 & 6.29 & 8.19 & 9.36 \\
\hline 20 & 4.92 & 5.10 & 5.38 & 5.08 & 5.82 & 6.02 & 5.78 & 6.38 & 8.35 & 9.37 \\
\hline 25 & 5.18 & 5.32 & 5.57 & 5.29 & 5.98 & 6.20 & 5.97 & 6.62 & 8.49 & 9.40 \\
\hline 30 & 5.34 & 5.46 & 5.71 & 5.45 & 6.10 & 6.35 & 6.16 & 6.82 & 8.55 & 9.40 \\
\hline 35 & 5.46 & 5.58 & 5.81 & 5.59 & 6.20 & 6.48 & 6.26 & 7.00 & 8.74 & 9.41 \\
\hline 40 & 5.55 & 5.67 & 5.90 & 5.72 & 6.29 & 6.58 & 6.40 & 7.18 & 8.60 & 9.40 \\
\hline 55 & 5.75 & 5.87 & 6.10 & 6.02 & 6.51 & 6.88 & 6.80 & 7.91 & 8.81 & 9.38 \\
\hline 70 & 5.89 & 6.02 & 6.26 & 6.30 & 6.68 & 7.13 & 7.38 & 8.28 & 8.94 & 9.36 \\
\hline 85 & 5.99 & 6.13 & 6.39 & 6.50 & 6.83 & 7.39 & 8.01 & 8.40 & 9.01 & 9.34 \\
\hline 100 & 6.08 & 6.23 & 6.50 & 6.64 & 6.97 & 7.66 & 8.24 & 8.43 & 9.06 & 9.31 \\
\hline 130 & 6.22 & 6.39 & 6.69 & 6.85 & 7.23 & 8.04 & 8.11 & 8.48 & 8.99 & 9.26 \\
\hline 160 & 6.33 & 6.53 & 6.85 & 7.04 & 7.45 & 8.14 & 8.19 & 8.51 & 8.89 & 9.22 \\
\hline 220 & 6.53 & 6.74 & 7.09 & 7.31 & 7.70 & 8.17 & 8.23 & 8.61 & 8.84 & 9.16 \\
\hline 280 & 6.71 & 6.91 & 7.36 & 7.49 & 7.82 & 8.20 & 8.19 & 8.48 & 8.76 & 9.09 \\
\hline 340 & 6.90 & 7.07 & 7.45 & 7.62 & 7.89 & 8.08 & 8.21 & 8.43 & 8.79 & 9.03 \\
\hline
\end{tabular}




\begin{tabular}{|r|r|r|r|r|r|r|r|r|r|r|}
\hline 400 & 7.08 & 7.23 & 7.59 & 7.68 & 7.95 & 8.12 & 8.25 & 8.44 & 8.74 & 8.97 \\
\hline 460 & 7.27 & 7.33 & 7.67 & 7.75 & 8.01 & 8.14 & 8.25 & 8.42 & 8.76 & 8.90 \\
\hline 1430 & 7.47 & 7.43 & 7.69 & 7.82 & 7.72 & 8.18 & 8.25 & 8.26 & 8.68 & 8.51 \\
\hline
\end{tabular}


Appendix Table 7.2.2 Ca changes with the neutralization of acid solution by limestone chips.

\begin{tabular}{|c|c|c|c|c|c|c|c|c|c|c|}
\hline & & & & & & \multicolumn{5}{|c|}{$\begin{array}{r}\text { Proton acid by } 6.3 \sim 11 \mathrm{~mm} \\
\text { crushed limestone chips }\end{array}$} \\
\hline Ellips. & $\begin{array}{c}\mathrm{Ca} \\
(\mathrm{mM} / \mathrm{L})\end{array}$ & $\begin{array}{c}\mathrm{Ca} \\
(\mathrm{mM} / \mathrm{L})\end{array}$ & $\begin{array}{c}\mathrm{Ca} \\
(\mathrm{mM} / \mathrm{L})\end{array}$ & $\begin{array}{c}\mathrm{Ca} \\
(\mathrm{mM} / \mathrm{L})\end{array}$ & $\begin{array}{c}\mathrm{Ca} \\
(\mathrm{mM} / \mathrm{L})\end{array}$ & $\begin{array}{c}\mathrm{Ca} \\
(\mathrm{mM} / \mathrm{L})\end{array}$ & \begin{tabular}{|c|c|c|}
$\mathrm{Ca}$ \\
$(\mathrm{mM} / \mathrm{L})$
\end{tabular} & \begin{tabular}{|c|}
$\mathrm{Ca}$ \\
$(\mathrm{mM} / \mathrm{L})$
\end{tabular} & \begin{tabular}{|c|c|c|}
$\mathrm{Ca}$ \\
$(\mathrm{mM} / \mathrm{L})$
\end{tabular} & $\begin{array}{c}\mathrm{Ca} \\
(\mathrm{mM} / \mathrm{L})\end{array}$ \\
\hline Time & $\mathrm{PH}$ & $\mathrm{PH}$ & $\mathrm{PH}$ & $\mathrm{PH}$ & $\mathrm{PH}$ & $\mathrm{PH}$ & $\mathrm{PH}$ & $\mathrm{PH}$ & $\mathrm{PH}$ & $\mathrm{PH}$ \\
\hline & 1.75 & 2.0 & 2.25 & 2.5 & 2.75 & 3.0 & 3.25 & 3.5 & 3.75 & \\
\hline 0 & 0.10 & 0.04 & 0.05 & 0.04 & 0.05 & 0.04 & 0.04 & 0.04 & 0.02 & 0.04 \\
\hline 0.5 & 0.42 & 0.17 & 0.09 & 0.06 & 0.07 & 0.04 & 0.04 & 0.03 & 0.02 & 0.03 \\
\hline 1 & 0.71 & 0.31 & 0.20 & 0.13 & 0.11 & 0.06 & 0.03 & 0.03 & 0.02 & 0.03 \\
\hline 1.5 & 0.99 & 0.44 & 0.28 & 0.18 & 0.14 & 0.06 & 0.04 & 0.04 & 0.02 & 0.03 \\
\hline 2 & 1.17 & 0.56 & 0.39 & 0.20 & 0.17 & 0.06 & 0.04 & 0.04 & 0.02 & 0.03 \\
\hline 2.5 & 1.36 & 0.66 & 0.44 & 0.22 & 0.19 & 0.08 & 0.04 & 0.04 & 0.02 & 0.03 \\
\hline 3 & 1.53 & 0.78 & 0.53 & 0.26 & 0.21 & 0.08 & 0.05 & 0.04 & 0.02 & 0.03 \\
\hline 3.5 & 1.63 & 0.82 & 0.58 & 0.28 & 0.24 & 0.09 & 0.05 & 0.04 & 0.02 & 0.03 \\
\hline 4 & 1.76 & 0.92 & 0.75 & 0.29 & 0.25 & 0.10 & 0.05 & 0.05 & 0.02 & 0.03 \\
\hline 4.5 & 1.88 & 1.01 & 0.59 & 0.30 & 0.26 & 0.10 & 0.06 & 0.05 & 0.02 & 0.03 \\
\hline 5 & 1.77 & 1.04 & 0.64 & 0.32 & 0.26 & 0.10 & 0.05 & 0.05 & 0.02 & 0.03 \\
\hline 6 & 2.15 & 1.13 & 0.74 & 0.33 & 0.27 & 0.10 & 0.07 & 0.05 & 0.02 & 0.04 \\
\hline 7 & 2.12 & 1.15 & 0.74 & 0.34 & 0.28 & 0.11 & 0.05 & 0.05 & 0.02 & 0.03 \\
\hline 8 & 2.42 & 1.26 & 0.96 & 0.36 & 0.29 & 0.11 & 0.05 & 0.05 & 0.02 & 0.03 \\
\hline 9 & 2.41 & 1.28 & 0.63 & 0.36 & 0.28 & 0.12 & 0.06 & 0.05 & 0.02 & 0.03 \\
\hline 10 & 2.34 & 1.30 & 0.80 & 0.37 & 0.27 & 0.11 & 0.06 & 0.05 & 0.02 & 0.03 \\
\hline 12 & 2.34 & 1.35 & 0.87 & 0.37 & 0.28 & 0.12 & 0.06 & 0.06 & 0.02 & 0.03 \\
\hline 14 & 2.45 & 1.26 & 0.91 & 0.37 & 0.30 & 0.12 & 0.06 & 0.06 & 0.02 & 0.03 \\
\hline 16 & 2.50 & 1.37 & 0.88 & 0.37 & 0.29 & 0.13 & 0.07 & 0.06 & 0.02 & 0.04 \\
\hline 18 & 2.52 & 1.36 & 0.82 & 0.37 & 0.32 & 0.13 & 0.07 & 0.06 & 0.02 & 0.04 \\
\hline 20 & 2.58 & 1.32 & 0.79 & 0.38 & 0.29 & 0.13 & 0.07 & 0.06 & 0.02 & 0.03 \\
\hline 25 & 2.75 & 1.32 & 0.85 & 0.41 & 0.30 & 0.14 & 0.08 & 0.07 & 0.02 & 0.04 \\
\hline 30 & 2.77 & 1.34 & 0.88 & 0.41 & 0.31 & 0.15 & 0.08 & 0.08 & 0.03 & 0.04 \\
\hline 35 & 2.78 & 1.42 & 0.95 & 0.42 & 0.31 & 0.15 & 0.09 & 0.08 & 0.03 & 0.03 \\
\hline 40 & 2.82 & 1.38 & 0.93 & 0.42 & 0.33 & 0.16 & 0.09 & 0.08 & 0.03 & 0.04 \\
\hline 55 & 2.85 & 1.44 & 0.96 & 0.42 & 0.34 & 0.18 & 0.09 & 0.09 & 0.03 & 0.04 \\
\hline 70 & 2.92 & 1.47 & 1.00 & 0.46 & 0.32 & 0.19 & 0.10 & 0.09 & 0.03 & 0.04 \\
\hline 85 & 3.07 & 1.47 & 1.03 & 0.46 & 0.35 & 0.18 & 0.09 & 0.09 & 0.03 & 0.04 \\
\hline 100 & 3.06 & 1.47 & 1.10 & 0.47 & 0.39 & 0.20 & 0.10 & 0.09 & 0.03 & 0.04 \\
\hline 130 & 3.05 & 1.46 & 1.07 & 0.49 & 0.40 & 0.20 & 0.09 & 0.09 & 0.03 & 0.04 \\
\hline 160 & 3.14 & 1.50 & 1.06 & 0.52 & 0.42 & 0.21 & 0.10 & 0.09 & 0.03 & 0.04 \\
\hline 220 & 3.15 & 1.51 & 1.05 & 0.53 & 0.39 & 0.19 & 0.11 & 0.09 & 0.03 & 0.04 \\
\hline 280 & 2.99 & 1.56 & 1.05 & 0.52 & 0.39 & 0.20 & 0.11 & 0.09 & 0.03 & 0.04 \\
\hline 340 & 3.05 & 1.56 & 1.03 & 0.51 & 0.40 & 0.21 & 0.11 & 0.09 & 0.04 & 0.04 \\
\hline
\end{tabular}




\begin{tabular}{|r|r|r|r|r|r|r|r|r|r|r|}
\hline 400 & 3.14 & 1.58 & 1.10 & 0.52 & 0.41 & 0.22 & 0.12 & 0.10 & 0.04 & 0.05 \\
\hline 460 & 3.10 & 1.62 & 1.08 & 0.53 & 0.40 & 0.20 & 0.12 & 0.10 & 0.04 & 0.06 \\
\hline 1430 & 2.89 & 1.52 & 0.89 & 0.46 & 0.41 & 0.20 & 0.15 & 0.12 & 0.05 & 0.15 \\
\hline
\end{tabular}




\section{Appendix Figure 7.2.1 4}

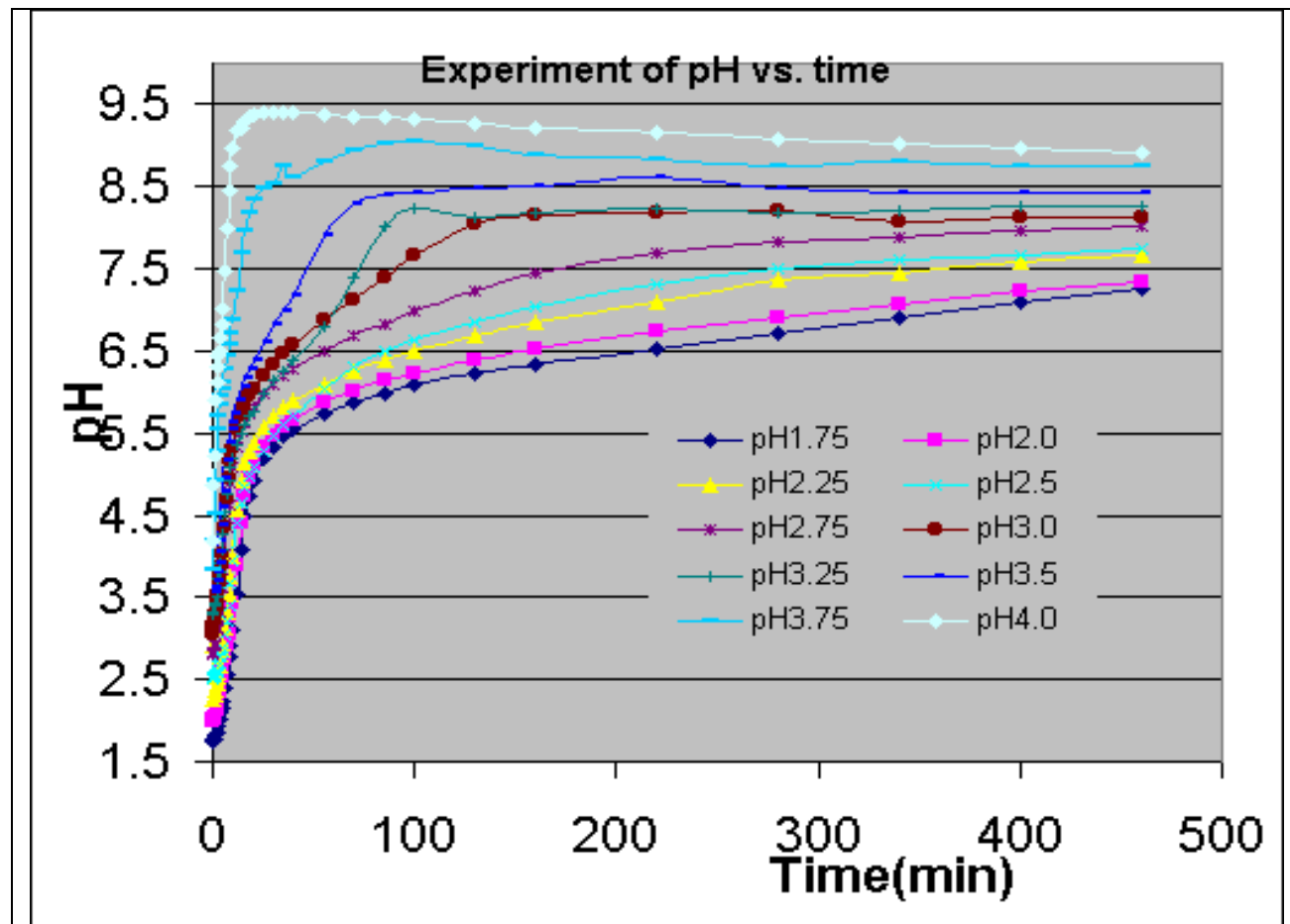

Appendix Figure 7.2.1 pH changes as time.

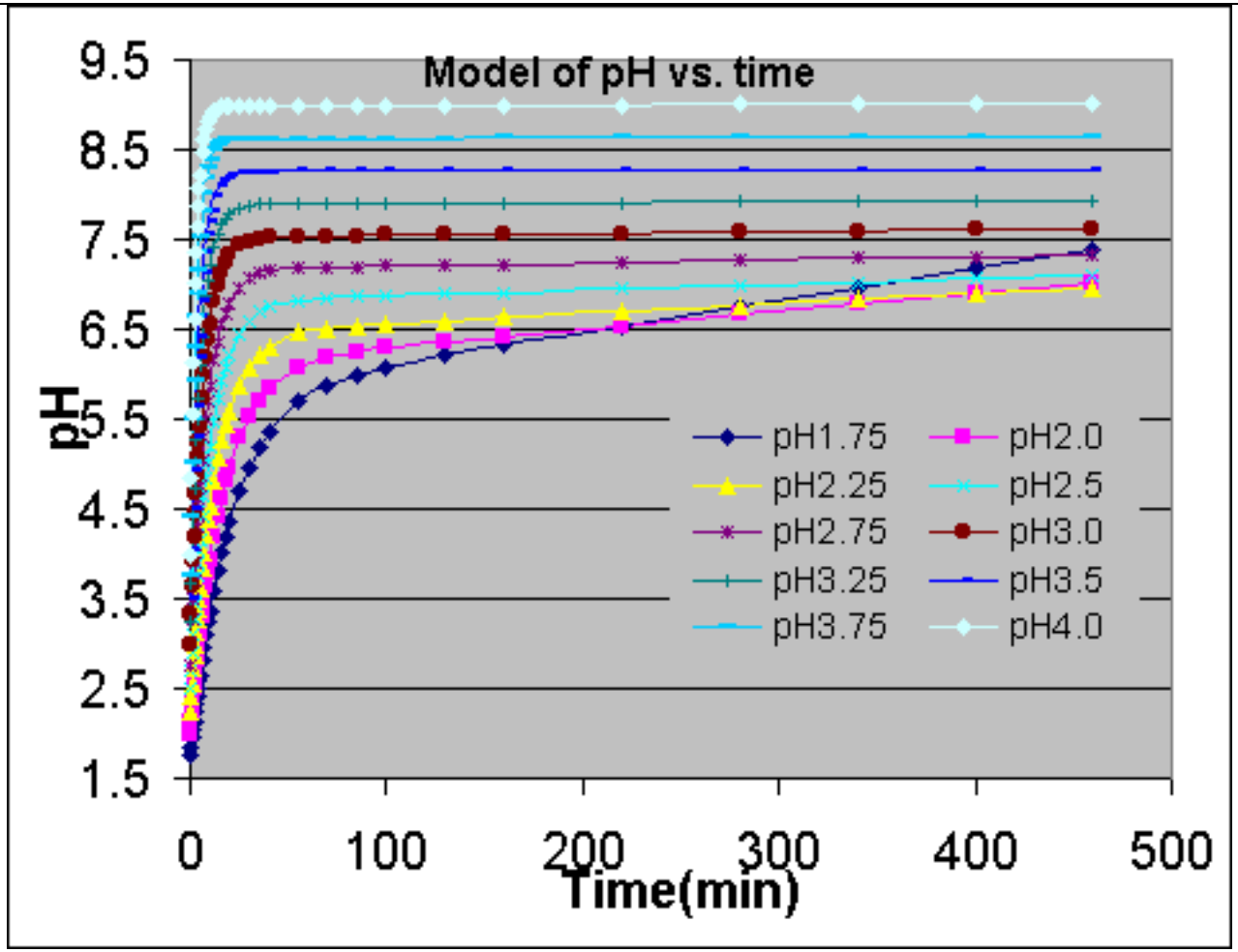

Appendix Figure 7.2.2 Modeling pH changes as time. 


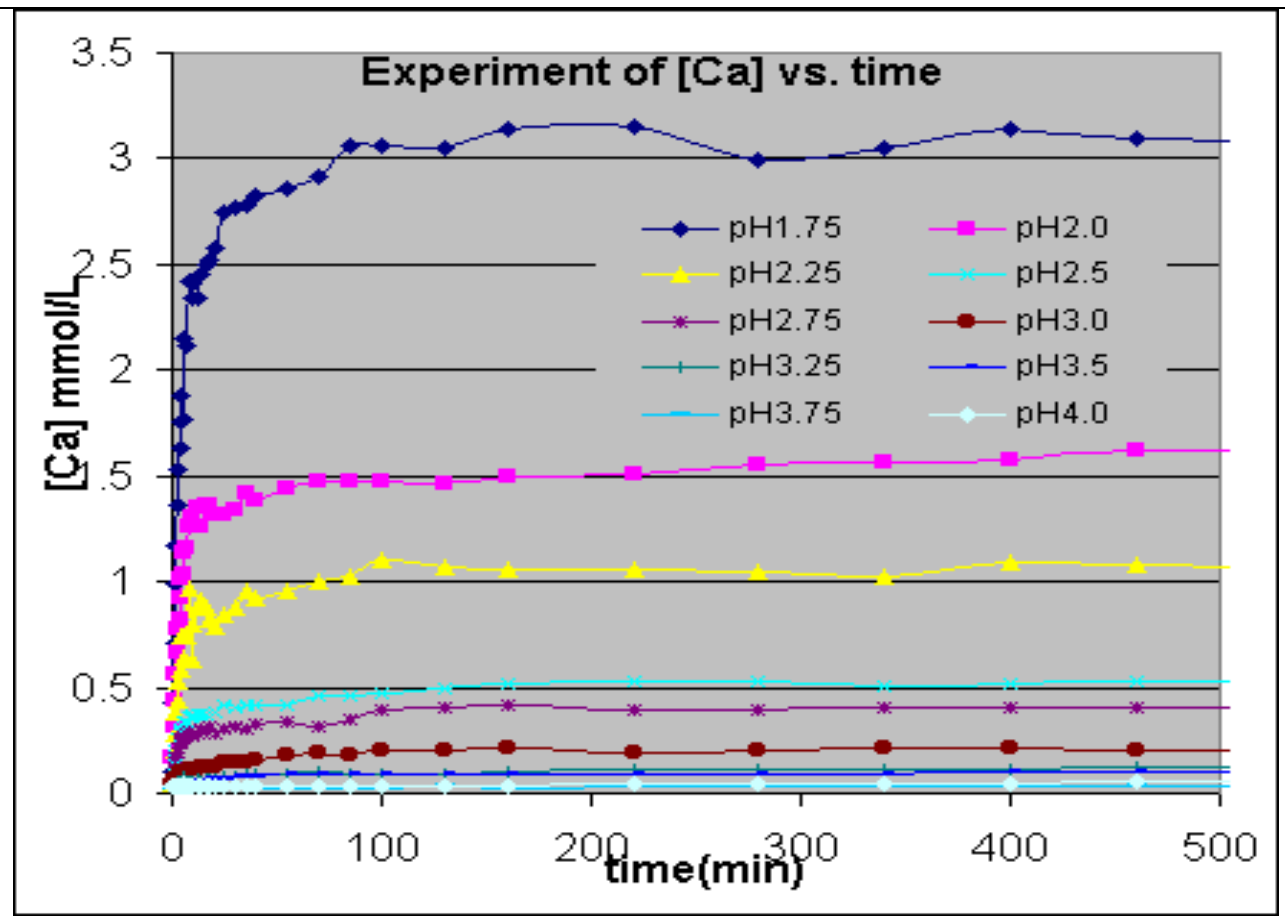

Appendix Figure 7.2.3 Ca changes as time.

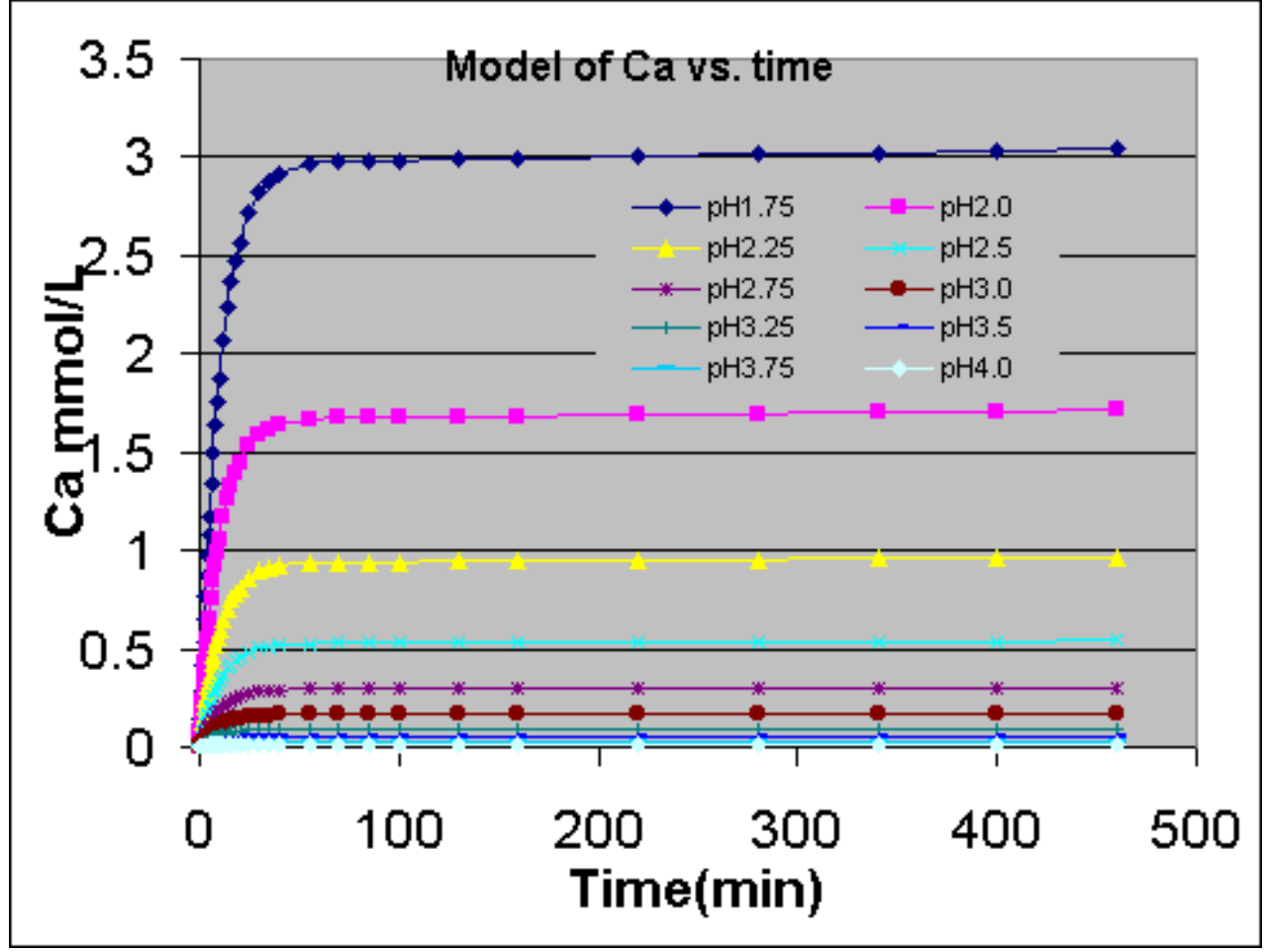

Appendix Figure 7.2.4 Modeling Ca changes as time. 
Appendix Table 7.3.1 The neutralization test of proton acid solution $(\mathrm{pHi}=3)$ by different limestone chips.

\begin{tabular}{|c|c|c|c|c|c|c|c|c|}
\hline \multicolumn{3}{|c|}{$\begin{array}{l}\text { Soln Type Heavy } \\
\text { Coat }\end{array}$} & \multicolumn{6}{|c|}{ Soln Type Int coat Soln Type Fresh } \\
\hline \multirow[t]{2}{*}{$2 / 22$} & /99pH: 3.0 & Ngt:150.506 & $2 / 22$ & 99pH: 3.0 & Ngt:148.518 & $2 / 22 /$ & $/ 99 \mathrm{pH}: 3.0$ & Wgt:144.002 \\
\hline & $\mathrm{pH}$ & Ca(dilute) & Time & $\mathrm{pH}$ & $\mathrm{Ca}$ (dilute) & Time & $\mathrm{pH}$ & Ca(dilute) \\
\hline 0 & 3.00 & $\begin{array}{r} \\
0.07\end{array}$ & 0 & 3.00 & 0.05 & \begin{tabular}{|l|l|}
5 & 0 \\
5
\end{tabular} & 3.00 & \\
\hline 0.5 & 3.03 & 0.55 & 0.5 & 3.02 & 0.34 & 0.5 & 3.02 & 0.04 \\
\hline 1 & 3.04 & 0.55 & 1 & 3.04 & 0.4 & 1 & 3.04 & 0.06 \\
\hline 1.5 & 3.06 & 1.02 & 1.5 & 3.05 & 0.57 & 1.5 & 3.07 & 0.08 \\
\hline 2 & 3.08 & 1.12 & 2 & 3.06 & 0.61 & 2 & 3.11 & 0.1 \\
\hline 2.5 & 3.10 & 1.42 & 2.5 & 3.07 & 0.86 & 2.5 & 3.14 & 0.12 \\
\hline 3 & 3.11 & 1.62 & 3 & 3.08 & 1.02 & 3 & 3.16 & 0.15 \\
\hline 3.5 & 3.13 & 1.75 & 3.5 & 3.09 & 1.36 & 3.5 & 3.19 & 0.16 \\
\hline 44 & 3.14 & 1.84 & 4 & 3.10 & 1.19 & 4 & 3.22 & 0.18 \\
\hline 4.5 & 3.16 & 1.94 & 4.5 & 3.11 & 1.35 & 4.5 & 3.26 & 0.19 \\
\hline 5 & 3.18 & 2.16 & 5 & 3.13 & 1.42 & 5 & $3.2 \varepsilon$ & 0.23 \\
\hline 6 & 3.21 & 2.44 & 6 & 3.15 & 1.77 & 6 & 3.36 & 0.27 \\
\hline 7 & 3.24 & 2.59 & 7 & 3.17 & 2 & 7 & 3.43 & 0.31 \\
\hline 8 & 3.29 & 3.03 & 8 & 3.20 & 2.17 & 8 & 3.50 & 0.34 \\
\hline 9 & 3.32 & 3.28 & 9 & & & 9 & $3.5 \varepsilon$ & 0.42 \\
\hline 10 & 3.35 & 3.48 & 10 & 3.25 & 2.38 & 10 & 3.65 & 0.47 \\
\hline 12 & 3.43 & 3.7 & 12 & 3.30 & 2.9 & 12 & 3.82 & 0.57 \\
\hline 14 & 3.51 & 4.24 & 14 & 3.35 & 3.3 & 14 & 4.02 & 0.61 \\
\hline 16 & 3.59 & 4.65 & 16 & 3.41 & 3.74 & 16 & 4.22 & 0.66 \\
\hline 18 & 3.67 & 4.77 & 18 & 3.46 & 3.88 & 18 & 4.45 & 0.69 \\
\hline 20 & 3.75 & 5.04 & 20 & 3.52 & 4.1 & 20 & 4.72 & 0.81 \\
\hline 25 & 4.00 & 5.65 & 25 & 3.66 & 4.8 & 25 & $5.5 \varepsilon$ & 0.87 \\
\hline 30 & 4.22 & 6.38 & 30 & 3.82 & 4.98 & 30 & 5.67 & 0.91 \\
\hline 35 & 4.54 & 5.66 & 35 & 3.98 & 5.23 & 35 & 5.78 & 0.96 \\
\hline 40 & 4.83 & 6.12 & 40 & 4.16 & 5.72 & 40 & 5.92 & 1.07 \\
\hline 55 & & & 55 & 4.76 & 5.96 & 55 & 6.23 & 1.05 \\
\hline 70 & 5.83 & 6.66 & 70 & 5.33 & 6 & 70 & 6.45 & 1.08 \\
\hline 85 & 6.07 & 6.69 & 85 & 5.65 & 6.58 & 85 & 6.62 & 1.09 \\
\hline 100 & 6.23 & 6.86 & 100 & 5.88 & 6.52 & 100 & 6.78 & 1.25 \\
\hline 130 & & & 130 & 6.21 & 6.77 & 130 & 6.94 & 1.34 \\
\hline 160 & 6.77 & 7.44 & 160 & 6.52 & 7.05 & 160 & 7.10 & 1.42 \\
\hline 220 & 7.23 & 8.23 & 220 & 6.93 & 7.8 & 220 & 7.65 & 1.48 \\
\hline 320 & 7.84 & 8.7 & 280 & 7.34 & 7.97 & 280 & & 1.55 \\
\hline & & & 380 & 7.87 & 8.49 & & & \\
\hline & & & & & & & & \\
\hline
\end{tabular}


Appendix Table 7.3.2 The neutralization of proton acid solution $(\mathrm{pHi}=2.5)$ by fresh limestone chips.

\begin{tabular}{|c|c|c|c|c|c|}
\hline \multicolumn{2}{|c|}{ 3/8/99 Soln Type } & pH: 2.5 & \multicolumn{2}{|c|}{ 3/12/99 Soln Type } & \multirow[t]{2}{*}{ pH: 2.5} \\
\hline Wgt:149.095 & Coated & & Wgt:143.967 & Fresh & \\
\hline Time & $\mathrm{pH}$ & Ca(dilute) & Time & $\mathrm{pH}$ & Ca(dilute) \\
\hline 0 & 2.50 & $\begin{array}{l}0.01 \\
\end{array}$ & 0 & 2.50 & $\begin{array}{l}-0.05 \\
\end{array}$ \\
\hline 1 & 2.52 & 2.61 & 1 & 2.55 & 2.88 \\
\hline 2 & 2.55 & 4.64 & 2 & 2.59 & 4.74 \\
\hline 3 & 2.57 & 6.16 & 3 & 2.64 & 6.26 \\
\hline 4 & 2.59 & 7.77 & 4 & 2.69 & 7.67 \\
\hline 5 & 2.62 & 10.40 & 5 & & \\
\hline 7 & 2.67 & 12.70 & 7 & 2.88 & 12.05 \\
\hline 9 & 2.72 & 11.30 & 9 & 2.98 & 13.72 \\
\hline 11 & 2.78 & 15.72 & 11 & 3.09 & 14.71 \\
\hline 13 & 2.83 & 18.82 & 13 & 3.22 & 15.52 \\
\hline 15 & 2.88 & 20.78 & 15 & 3.35 & 17.83 \\
\hline 20 & 3.02 & 18.57 & 20 & 3.70 & 18.94 \\
\hline 25 & 3.16 & 24.88 & 25 & 4.10 & 19.81 \\
\hline 30 & 3.30 & 27.85 & 30 & 4.63 & 19.51 \\
\hline 35 & 3.46 & 30.07 & 35 & 5.06 & 20.28 \\
\hline 40 & 3.61 & 29.60 & 40 & 5.19 & 20.83 \\
\hline 50 & 3.94 & 28.12 & 50 & 5.48 & 20.84 \\
\hline 60 & 4.33 & 31.81 & 60 & 5.67 & 21.87 \\
\hline 70 & 4.73 & 32.65 & 70 & 5.82 & 21.81 \\
\hline 80 & 5.02 & 30.57 & 80 & 5.93 & 22.16 \\
\hline 90 & 5.22 & 31.10 & 90 & 6.03 & 19.98 \\
\hline 110 & 5.50 & 33.63 & 110 & 6.21 & 23.2 \\
\hline 130 & 5.68 & 34.18 & 130 & 6.35 & 24.44 \\
\hline 150 & 5.83 & 33.10 & 150 & & \\
\hline 170 & 5.96 & 32.18 & 170 & & \\
\hline 190 & 6.09 & 35.04 & 190 & & \\
\hline 220 & 6.26 & 35.82 & 220 & 6.91 & 26.07 \\
\hline 250 & 6.43 & 34.27 & 250 & 7.07 & 24.87 \\
\hline 280 & 6.56 & 33.67 & 280 & 7.21 & 25.28 \\
\hline 310 & & & 310 & 7.44 & 27.35 \\
\hline 340 & 6.83 & 36.04 & 370 & 7.55 & 27.03 \\
\hline 400 & 7.10 & 36.22 & & & \\
\hline & & & & & \\
\hline & & & & & \\
\hline & & & & & \\
\hline
\end{tabular}


Appendix Table 7.3.3 The neutralization of proton acid solution $(\mathrm{pHi}=3)$ by fresh limestone chips.

\begin{tabular}{|c|c|c|c|c|c|}
\hline \multicolumn{3}{|c|}{ 3/29/99 Soln Type } & \multicolumn{2}{|c|}{ 3/29/99 Soln Type } & \multirow[t]{2}{*}{ pH: $\mathbf{3 . 0}$} \\
\hline & Coated & & & Fresh & \\
\hline Time & $\mathrm{pH}$ & Ca(dilute) & Time & $\mathrm{pH}$ & $\mathrm{Ca}$ (dilute) \\
\hline 0 & 3.04 & 0.07 & 0 & 3.05 & 0.07 \\
\hline 1 & 3.06 & 0.34 & 1 & 3.12 & 0.74 \\
\hline 2 & 3.08 & 0.48 & 2 & 3.19 & 1.17 \\
\hline 3 & 3.09 & 0.66 & 3 & 3.26 & 1.59 \\
\hline 4 & 3.11 & 0.86 & 4 & 3.31 & 1.91 \\
\hline 5 & 3.13 & 0.97 & 5 & 3.38 & 2.26 \\
\hline 7 & 3.16 & 1.19 & 7 & 3.52 & 2.76 \\
\hline 9 & 3.18 & 1.45 & 9 & 3.67 & 3.18 \\
\hline 11 & 3.22 & 1.61 & 11 & 3.84 & 3.53 \\
\hline 13 & 3.25 & 1.84 & 13 & 4.03 & 3.80 \\
\hline 15 & 3.28 & 2.2 & 15 & 4.22 & 3.89 \\
\hline 20 & 3.36 & 2.48 & 20 & 4.86 & 4.19 \\
\hline 25 & 3.45 & 2.89 & 25 & 5.37 & 4.40 \\
\hline 30 & 3.54 & 3.18 & 30 & 5.62 & 4.60 \\
\hline 35 & 3.63 & 3.47 & 35 & 5.80 & 4.77 \\
\hline 40 & 3.72 & 3.97 & 40 & 5.94 & 4.90 \\
\hline 50 & 3.93 & 4.23 & 50 & 6.14 & 5.17 \\
\hline 60 & 4.16 & 4.33 & 60 & 6.31 & 5.47 \\
\hline 70 & 4.41 & 4.36 & 70 & 6.44 & 5.67 \\
\hline 80 & 4.76 & 4.52 & 80 & 6.60 & 5.78 \\
\hline 90 & 5.09 & 4.81 & 90 & 6.70 & 5.89 \\
\hline 110 & 5.61 & 4.8 & 110 & 6.95 & 6.30 \\
\hline 130 & 5.92 & 5.02 & 130 & 7.14 & 6.57 \\
\hline 150 & 6.15 & 5.17 & 150 & 7.40 & 6.65 \\
\hline 170 & 6.33 & 5.3 & 170 & 7.64 & 6.97 \\
\hline 190 & 6.51 & 5.48 & 190 & 7.81 & 7.15 \\
\hline 220 & 6.73 & 5.72 & 220 & & \\
\hline 250 & 6.98 & 6.12 & 250 & & \\
\hline 280 & 7.19 & 5.99 & 280 & & \\
\hline 310 & & & 310 & & \\
\hline 340 & & & 340 & & \\
\hline 400 & & & 400 & & \\
\hline 460 & & & 460 & & \\
\hline 520 & & & 520 & & \\
\hline & & & & & \\
\hline
\end{tabular}


Appendix Table 7.3.4 The neutralization of proton acid solution $(\mathrm{pHi}=3.5)$ by fresh limestone chips.

\begin{tabular}{|c|c|c|c|c|c|}
\hline \multicolumn{3}{|c|}{ 3/30/99 Soln Type } & \multicolumn{2}{|c|}{ 3/30/99 Soln Type } & pH: 3.5 \\
\hline & Fresh & & & Coated & \\
\hline Tim? & & & Timn & & \\
\hline Time & $\mathrm{pH}$ & Ca(dilute) & Iime & $\mathrm{pH}$ & Ca(dilute) \\
\hline 0 & 3.55 & 0.02 & 0 & 3.57 & 0.01 \\
\hline 1 & 3.70 & 0.38 & 1 & 3.65 & 0.12 \\
\hline 2 & 3.86 & 0.49 & 2 & 3.67 & 0.25 \\
\hline 3 & 4.01 & 0.60 & 3 & 3.69 & 0.16 \\
\hline 4 & 4.25 & 0.48 & 4 & 3.71 & 0.19 \\
\hline 5 & 4.38 & 0.78 & 5 & 3.75 & 0.22 \\
\hline 7 & 4.72 & 0.86 & 7 & 3.79 & 0.30 \\
\hline 9 & 5.17 & 0.93 & 9 & 3.85 & 0.34 \\
\hline 11 & 5.48 & 1.02 & 11 & 3.90 & 0.40 \\
\hline 13 & 5.70 & 1.10 & 13 & 3.94 & 0.44 \\
\hline 15 & 5.87 & 1.11 & 15 & 3.99 & 0.50 \\
\hline 20 & 6.14 & 1.17 & 20 & 4.13 & 0.59 \\
\hline 25 & 6.36 & 1.34 & 25 & 4.28 & 0.69 \\
\hline 30 & 6.54 & 0.14 & 30 & 4.45 & 0.75 \\
\hline 35 & 6.71 & 1.50 & 35 & 4.66 & 0.84 \\
\hline 40 & 6.86 & 1.66 & 40 & 4.90 & 0.89 \\
\hline 50 & 7.95 & 1.72 & 50 & 5.40 & 0.96 \\
\hline 60 & 8.17 & 1.82 & 60 & 5.76 & 1.06 \\
\hline 70 & 8.37 & 1.89 & 70 & 5.99 & 1.10 \\
\hline 80 & 8.50 & 1.91 & 80 & 6.17 & 1.15 \\
\hline 90 & & & 90 & 6.32 & 1.22 \\
\hline 110 & & & 110 & 6.01 & 1.34 \\
\hline 130 & & & 130 & 6.88 & 1.41 \\
\hline 150 & & & 150 & 7.13 & 1.49 \\
\hline 170 & & & 170 & 7.47 & 1.51 \\
\hline 190 & & & 190 & 7.91 & 1.58 \\
\hline 220 & & & 220 & & \\
\hline 250 & & & 250 & & \\
\hline 280 & & & 280 & & \\
\hline 310 & & & 310 & & \\
\hline 340 & & & 340 & & \\
\hline 400 & & & 400 & & \\
\hline 460 & & & 460 & & \\
\hline 520 & & & 520 & & \\
\hline & & & & & \\
\hline
\end{tabular}


Appendix Table 7.3.5 The neutralization of proton acid solution $(\mathrm{pHi}=4.0)$ by fresh limestone chips.

\begin{tabular}{|c|c|c|c|c|c|}
\hline $3 / 30 / 99$ & Soln Type & pH: 4.0 & $3 / 30 / 99$ & Soln Type & pH: 4.0 \\
\hline & Coated & & & Fresh & \\
\hline Time & $n$ & Cosdilutos) & Timn & $\ln$ & Cosdiluto) \\
\hline 0 & 4.14 & $\begin{array}{r}0.01 \\
\end{array}$ & 0 & 4.04 & 0.04 \\
\hline 1 & 4.24 & 0.02 & 1 & 4.21 & 0.18 \\
\hline 2 & 4.28 & 0.03 & 2 & 4.41 & 0.22 \\
\hline 3 & 4.32 & 0.04 & 3 & 4.63 & 0.26 \\
\hline 4 & 4.35 & 0.06 & 4 & 4.94 & 0.29 \\
\hline 5 & 4.38 & 0.05 & 5 & 5.28 & 0.31 \\
\hline 7 & 4.44 & 0.07 & $\overline{7}$ & 5.80 & 0.40 \\
\hline 9 & 4.52 & 0.11 & 9 & 6.10 & 0.44 \\
\hline 11 & 4.60 & 0.11 & 11 & 6.36 & 0.49 \\
\hline 13 & 4.70 & 0.15 & 13 & 6.56 & 0.53 \\
\hline 15 & 4.82 & 0.15 & 15 & 6.76 & 0.56 \\
\hline 20 & 5.18 & 0.19 & 20 & 8.30 & 0.67 \\
\hline 25 & 5.66 & 0.23 & 25 & 8.81 & 0.83 \\
\hline 30 & 5.97 & 0.27 & 30 & 8.96 & 0.79 \\
\hline 35 & 6.19 & 0.29 & 35 & 9.03 & 0.88 \\
\hline 40 & 6.39 & 0.30 & 40 & & \\
\hline 50 & 6.09 & 0.38 & 50 & & \\
\hline 60 & 7.01 & 0.40 & 60 & & \\
\hline 70 & 7.52 & 0.48 & 70 & & \\
\hline 80 & 8.21 & 0.56 & 80 & & \\
\hline 90 & & & 90 & & \\
\hline 110 & & & 110 & & \\
\hline 130 & & & 130 & & \\
\hline 150 & & & 150 & & \\
\hline 170 & & & 170 & & \\
\hline 190 & & & 190 & & \\
\hline 220 & & & 220 & & \\
\hline 250 & & & 250 & & \\
\hline 280 & & & 280 & & \\
\hline 310 & & & 310 & & \\
\hline 340 & & & 340 & & \\
\hline 400 & & & 400 & & \\
\hline 460 & & & 460 & & \\
\hline 520 & & & 520 & & \\
\hline & & & & & \\
\hline
\end{tabular}


Appendix Table 7.4.1 The neutralization of $0.0008 \mathrm{M}$ iron solutions $\left(\mathrm{FeCl}_{3}\right)$.

\section{1-0.0008Fe Limestone Neutralize FeCl3 Solution}

$[\mathrm{FeCl} 3]=0.0008 \mathrm{M} \mid$ Limestone Size = 6.3 11 mm; Initial Weight=99.697g;

\begin{tabular}{|l|l|}
\hline $\mathrm{FeCl} 3 * 6 \mathrm{H} 2 \mathrm{O}(\mathrm{Mol} . \mathrm{Wt}=270.32) \mathrm{Wt} .=0.087 \mathrm{~g}$ & {$[\mathrm{Fe}]=42 \mathrm{mg} / \mathrm{L}$} \\
\hline
\end{tabular}

The beaker filled with $400 \mathrm{ml}$ water $+\mathrm{FeCl}$, The solution $\mathrm{pH}=3.10 \quad[\mathrm{FeCl}]=0.0008 \mathrm{~mol} / \mathrm{L}$

Each time pick out $0.6 \mathrm{ml}$ (before\#15) and $1.0 \mathrm{ml}$ (After\#16) solution and dilute with $4 \mathrm{ml}$ of $2 \%$

HNO3 for Fe and Ca Analysis

\begin{tabular}{|c|c|c|c|c|c|c|c|}
\hline & & & & [Ca] ppm & {$[\mathrm{Fe}] \mathrm{ppm}$} & [Ca] ppm & {$[\mathrm{Fe}] \mathrm{ppm}$} \\
\hline & Time & React t & $\mathrm{pH}$ & Diluted & Diluted & Real & Real \\
\hline 1 & $10: 00$ & 0 & 3.10 & 0.01 & 8.64 & 0.10 & 66.24 \\
\hline 2 & 1 & 1 & 3.12 & 4.90 & 9.27 & 37.58 & 71.09 \\
\hline 3 & $1 ' 30$ & & 3.10 & & & & \\
\hline 4 & 2 & 2 & 3.09 & 6.01 & 8.27 & 46.05 & 63.42 \\
\hline 5 & $2 ' 30$ & & 3.08 & & & & \\
\hline 6 & 245 & & 3.09 & & & & \\
\hline 7 & 3 & 3 & 3.10 & 7.08 & 8.00 & 54.28 & 61.30 \\
\hline 8 & 4 & 4 & 3.13 & 8.53 & 8.29 & 65.37 & 63.53 \\
\hline 9 & 5 & 5 & 3.17 & 9.50 & 8.26 & 72.83 & 63.32 \\
\hline 10 & 6 & 6 & 3.26 & 10.35 & 8.27 & 79.35 & 63.37 \\
\hline 11 & 7 & 7 & 3.34 & 9.76 & 7.49 & 74.81 & 57.43 \\
\hline 12 & 8 & 8 & 3.41 & 10.49 & 7.35 & 80.41 & 56.33 \\
\hline 13 & 10 & 10 & 3.55 & 9.01 & 6.02 & 69.10 & 46.13 \\
\hline 14 & 12 & 12 & 3.87 & 12.79 & 7.38 & 98.03 & 56.56 \\
\hline 15 & 15 & 15 & 4.32 & 8.67 & 5.01 & 66.45 & 38.43 \\
\hline 16 & 19 & 19 & 4.73 & 8.85 & 4.44 & 67.87 & 34.06 \\
\hline 17 & 25 & 25 & 5.16 & 10.67 & 4.55 & 81.78 & 34.88 \\
\hline 18 & 33 & 33 & 5.50 & 10.25 & 3.55 & 78.61 & 27.25 \\
\hline 19 & 45 & 45 & & 10.15 & 2.98 & 77.79 & 22.81 \\
\hline 20 & 11:00 & 60 & 6.06 & 14.63 & 3.75 & 73.15 & 18.73 \\
\hline 21 & $11: 30$ & 90 & 6.39 & 16.28 & 3.17 & 81.40 & 15.87 \\
\hline 22 & $12: 15$ & 135 & 6.77 & 17.18 & 2.42 & 85.89 & 12.08 \\
\hline 23 & $13: 00$ & 180 & 7.04 & 17.36 & 1.81 & 86.78 & 9.03 \\
\hline 24 & 50 & 230 & 7.29 & 17.50 & 1.41 & 87.48 & 7.06 \\
\hline 25 & $15: 35$ & 275 & 7.58 & 18.27 & 1.31 & 91.37 & 6.57 \\
\hline 26 & $17: 12$ & 432 & 7.69 & 19.54 & 4.05 & 97.68 & 20.23 \\
\hline
\end{tabular}


Appendix Table 7.4.2 The neutralization of $0.0015 \mathrm{M}$ iron solutions $\left(\mathrm{FeCl}_{3}\right)$.

\begin{tabular}{|c|c|c|c|c|c|c|c|c|}
\hline & $\# 3$ beaker & $120 \mathrm{Cu}$ & 9/23/98 & ond & {$[\mathrm{FeCl} 3]=0.00$} & $15 \mathrm{M}$ & $22.60 \mathrm{C}$ & \\
\hline & Limestone $\mathrm{S}$ & Size = 6.3 1 & $1 \mathrm{~mm} ; \mathrm{Ir}$ & nitial Wei & $\mathrm{ht}=99.819 \mathrm{~g}$ & & & \\
\hline $\mathrm{FeCl} 3 * 6 \mathrm{H} 2 \mathrm{C}$ & D (Mol.Wt $=2$ & 270.32) Wt.= & $=0.164 \mathrm{~g}$ & & & & & $\mathrm{Fe}]=92 \mathrm{mg} / \mathrm{L}$ \\
\hline & The beake & ker filled with & $400 \mathrm{ml}$ & water $+\mathrm{F}$ & $\mathrm{Cl} 3$, The solut & ion $\mathrm{pH}=2$. & $86[\mathrm{FeCl} 3]=0$ & $0.0015 \mathrm{~mol} / \mathrm{L}$ \\
\hline & Each tim & ne pick out 0 . & $\overline{6 \mathrm{ml} \text { solut }}$ & tion and d & lute with $4 \mathrm{ml}$ & of $2 \% \mathrm{HNC}$ & $\mathrm{O} 3$ for $\mathrm{Fe}$ and & $\mathrm{Ca}$ Analysis \\
\hline & & & & & {$[\mathrm{Ca}] \mathrm{ppm}$} & {$[\mathrm{Fe}] \mathrm{ppm}$} & [Ca] ppm & {$[\mathrm{Fe}] \mathrm{ppm}$} \\
\hline Time & React t & $\mathrm{pH}$ & \begin{tabular}{|l|} 
Sample \\
\#
\end{tabular} & Observe & Diluted & Diluted & Real & Real \\
\hline 10:05 & 0 & 2.86 & $\underline{0}$ & & & & [Ca] ppm & {$[\mathrm{Fe}] \mathrm{ppm}$} \\
\hline 6 & 1 & 2.89 & 1 & & 6.03 & 15.42 & 46.3 & 118.2 \\
\hline 7 & 2 & 2.86 & 2 & & 7.64 & 13.77 & 58.6 & 105.6 \\
\hline 8 & 3 & 2.85 & 3 & & 9.61 & 13.65 & 73.7 & 104.6 \\
\hline 9 & 4 & 2.86 & 4 & & 10.35 & 13.29 & 79.4 & 101.9 \\
\hline 10 & 5 & 2.89 & 5 & & 12.09 & 13.13 & 92.7 & 100.6 \\
\hline 11 & 6 & 2.93 & 6 & & 12.42 & 12.73 & 95.2 & 97.6 \\
\hline 12 & 7 & 2.98 & 7 & & 13.12 & 12.90 & 100.6 & 98.9 \\
\hline 14 & 9 & 3.08 & 8 & & 14.16 & 12.51 & 108.6 & 95.9 \\
\hline 16 & 11 & 3.22 & 9 & & 16.85 & 12.68 & 129.1 & 97.2 \\
\hline 20 & 15 & 3.49 & 10 & & 17.18 & 12.00 & 131.7 & 92.0 \\
\hline 24 & 19 & 3.76 & 11 & & 18.06 & 11.15 & 138.5 & 85.4 \\
\hline 29 & 24 & 4.09 & 12 & & 18.99 & 9.02 & 145.6 & 69.2 \\
\hline 35 & 30 & 4.5 & 13 & & 18.37 & 13.51 & 140.9 & 103.6 \\
\hline 42 & 37 & 4.74 & 14 & & 20.25 & 6.99 & 155.2 & 53.6 \\
\hline 52 & 47 & 5.08 & 15 & & 19.40 & 5.66 & 148.8 & 43.4 \\
\hline 11:05 & 60 & 5.41 & 16 & & 37.53 & 7.90 & 287.7 & 60.6 \\
\hline 20 & 75 & 5.7 & 17 & & 22.33 & 4.43 & 171.2 & 34.0 \\
\hline 40 & 95 & 5.97 & 18 & & 23.35 & 5.22 & 179.0 & 40.0 \\
\hline 12:03 & 118 & 6.22 & 19 & & 22.72 & 2.97 & 174.2 & 22.7 \\
\hline 27 & 142 & $\begin{array}{ll}6.39 \\
\end{array}$ & 20 & & 25.05 & 3.03 & 192.0 & 23.2 \\
\hline 59 & 174 & 6.59 & 21 & & 24.06 & 2.13 & 184.4 & 16.3 \\
\hline 13:53 & 228 & 6.87 & 22 & & 24.46 & 1.64 & 187.5 & 12.6 \\
\hline $14: 55$ & 290 & \begin{tabular}{l|}
7.1 \\
\end{tabular} & 23 & & 29.24 & 2.65 & 224.1 & 20.3 \\
\hline $15: 56$ & 351 & 7.26 & 24 & & 26.65 & 2.79 & 204.3 & 21.4 \\
\hline 17:13 & 498 & \begin{tabular}{l|l}
7.39 \\
\end{tabular} & 25 & & 27.58 & 2.62 & 211.4 & 20.1 \\
\hline & & & & & & & & \\
\hline & & & & & & & & \\
\hline & & & & & & & & \\
\hline
\end{tabular}


Appendix Table 7.4.3 The neutralization of $0.003 \mathrm{M}$ iron solutions $\left(\mathrm{FeCl}_{3}\right)$.

\begin{tabular}{|c|c|c|c|c|c|c|c|c|}
\hline & $\begin{array}{l}\text { 1.1-U. } \\
\# 5 \text { beaker }\end{array}$ & oudet & 9/23/98 & (1) 1 & {$[\mathrm{FeCl} 3]=0.00$} & $3 \mathrm{M}$ & $22.6 \mathrm{oC}$ & \\
\hline & & Limestone & Size $=6$ & $3 \sim 11 \mathrm{~mm}$ & nitial Weight= & $=99.819 \mathrm{~g} ; \mathrm{L}$ & ast Weight $=$ & \\
\hline & $\overline{\mathrm{FeCl} 3 * 6 \mathrm{I}}$ & $\mathrm{H} 2 \mathrm{O}$ (Mol.W & $\mathrm{t}=270.32$ & $\mathrm{Wt} .=0.32$ & & & & $=168 \mathrm{mg} / \mathrm{L}$ \\
\hline The bea & aker filled wi & th $400 \mathrm{ml} \mathrm{wa}$ & ater $+\mathrm{FeC}$ & 13 , The solv & ion $\mathrm{pH}=2.313$ & $2.296,2.29$ & $92[\mathrm{FeCl} 3]=0$ & $0.003 \mathrm{~mol} / \mathrm{L}$ \\
\hline & Each & time pick ou & to $0.6 \mathrm{ml} \mathrm{so}$ & lution and & lute with $4 \mathrm{ml}$ & of $2 \% \mathrm{HNO}$ & 3 for $\mathrm{Fe}$ and & Ca Analysis \\
\hline & & & & & {$[\mathrm{Ca}] \mathrm{ppm}$} & {$[\mathrm{Fe}] \mathrm{ppm}$} & {$[\mathrm{Ca}] \mathrm{ppm}$} & {$[\mathrm{Fe}] \mathrm{ppm}$} \\
\hline Time & React t & $\mathrm{pH}$ & Sample\# & Observed & Diluted & Diluted & Real & Real \\
\hline $9: 20$ & 0 & 2.289 & 1 & & 0.29 & 40.68 & 2.2 & 311.9 \\
\hline 21 & 2 & 2.361 & 2 & & 3.94 & 33.90 & 30.2 & 259.9 \\
\hline 22 & & 2.456 & 3 & & 8.75 & 31.14 & 67.1 & 238.8 \\
\hline 24 & & 2.648 & 4 & & 14.51 & 27.91 & 111.3 & 214.0 \\
\hline 26 & & 2.853 & 5 & & 19.07 & 27.68 & 146.2 & 212.2 \\
\hline 28 & & 3.011 & 6 & & 21.95 & 26.26 & 168.3 & 201.3 \\
\hline 31 & & 3.058 & 7 & & 27.43 & 33.13 & 210.3 & 254.0 \\
\hline 34 & & 3.108 & 8 & & 29.03 & 26.32 & 222.6 & 201.8 \\
\hline 38 & & 3.245 & 9 & & 30.11 & 24.83 & 230.8 & 190.4 \\
\hline 42 & & 3.543 & 10 & & 33.10 & 26.06 & 253.7 & 199.8 \\
\hline 47 & & 4.153 & 11 & & 32.33 & 24.35 & 247.8 & 186.7 \\
\hline 52 & & 4.826 & 12 & & 33.84 & 24.16 & 259.4 & 185.3 \\
\hline 59 & & 5.233 & 13 & unclear & 34.44 & 29.90 & 264.0 & 229.2 \\
\hline 10:05 & & 5.392 & 14 & & 35.75 & 20.97 & 274.1 & 160.7 \\
\hline 11 & & 5.522 & 15 & & 39.70 & 20.76 & 304.4 & 159.1 \\
\hline 18 & & 5.64 & 16 & & 37.61 & 19.83 & 288.3 & 152.0 \\
\hline 29 & & 5.792 & 17 & & 35.94 & 18.02 & 275.6 & 138.2 \\
\hline 42 & & 5.935 & 18 & & 36.11 & 15.27 & 276.9 & 117.1 \\
\hline 52 & & 6.018 & 19 & & 37.16 & 14.50 & 284.9 & 111.1 \\
\hline 11:05 & & 6.136 & 20 & & 38.89 & 14.12 & 298.2 & 108.2 \\
\hline 20 & & 6.234 & 21 & & 40.55 & 14.18 & 310.9 & 108.7 \\
\hline 40 & & 6.339 & 22 & & 41.75 & 27.82 & 320.1 & 213.3 \\
\hline 12:03 & & 6.461 & 23 & & 40.85 & 11.85 & 313.2 & 90.9 \\
\hline 27 & & 6.57 & 24 & & 40.83 & 10.92 & 313.1 & 83.7 \\
\hline 58 & & 6.677 & 25 & & 42.93 & 9.64 & 329.1 & 73.9 \\
\hline & & & 26 & & 41.14 & 8.62 & 315.4 & 66.1 \\
\hline & & & 27 & & 42.09 & 8.20 & 322.7 & 62.8 \\
\hline $14: 55$ & & 7.027 & 27 & & 42.01 & 9.19 & 322.1 & 70.5 \\
\hline $17: 13$ & & 7.321 & 29 & & 48.71 & 12.98 & 373.4 & 99.5 \\
\hline & & & & & & & & \\
\hline
\end{tabular}


Appendix Table 7.4.4 The neutralization of $0.008 \mathrm{M}$ iron solutions $\left(\mathrm{FeCl}_{3}\right)$.

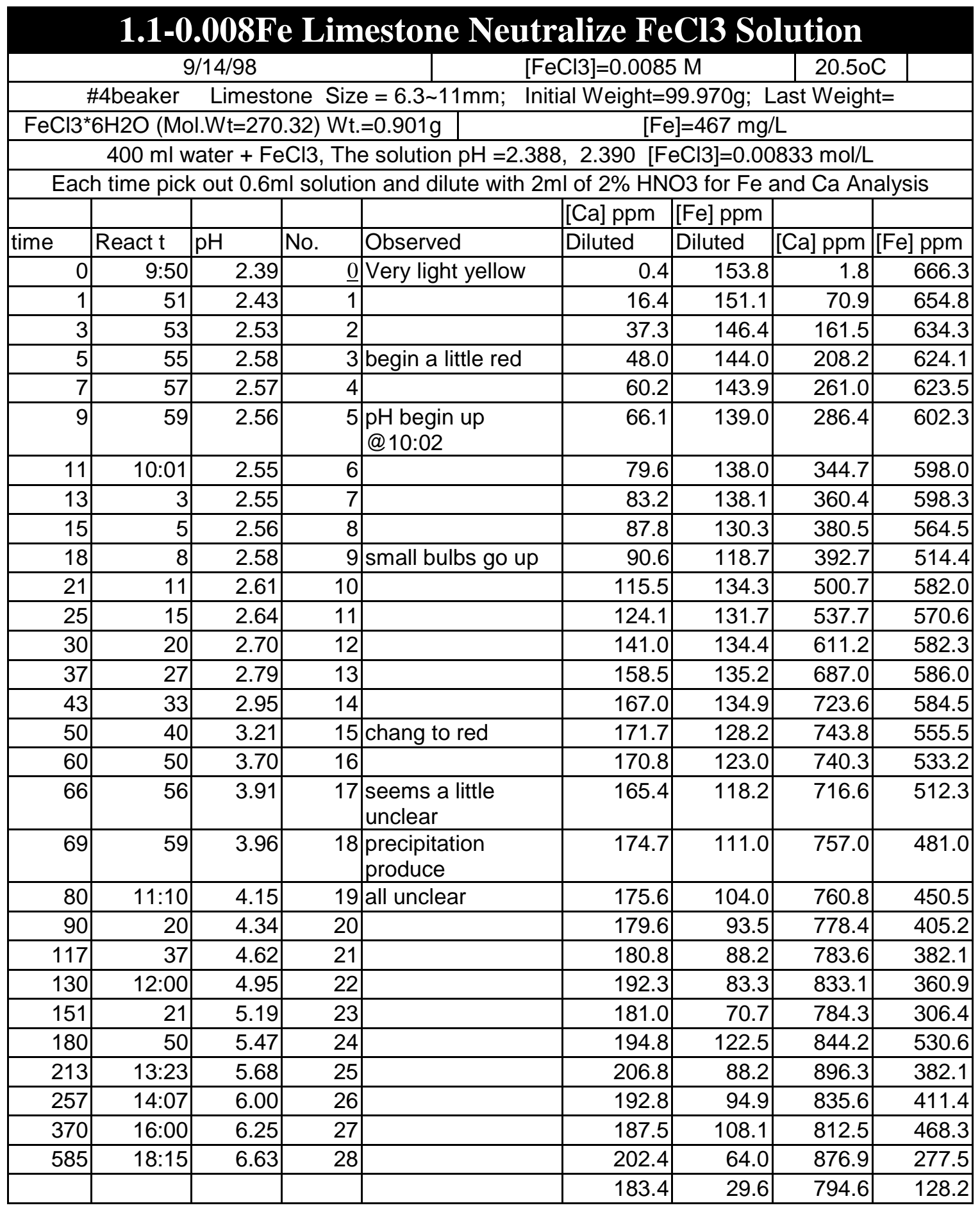


Appendix Table 7.4.5 The neutralization of $0.016 \mathrm{M}$ iron solutions $\left(\mathrm{FeCl}_{3}\right)$.

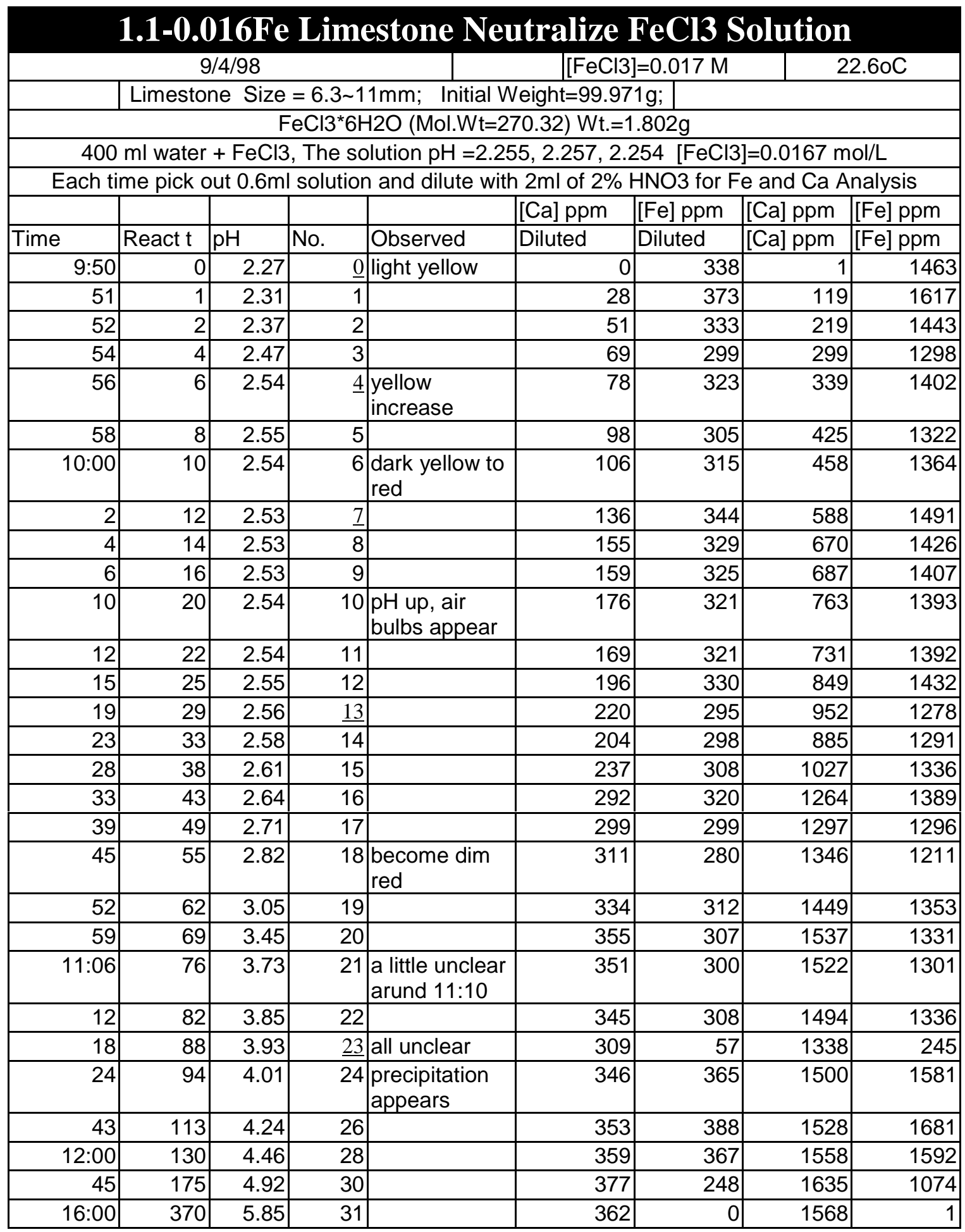


Appendix Table 7.4.6 The neutralization of 0.03M iron solutions $\left(\mathrm{FeCl}_{3}\right)$.

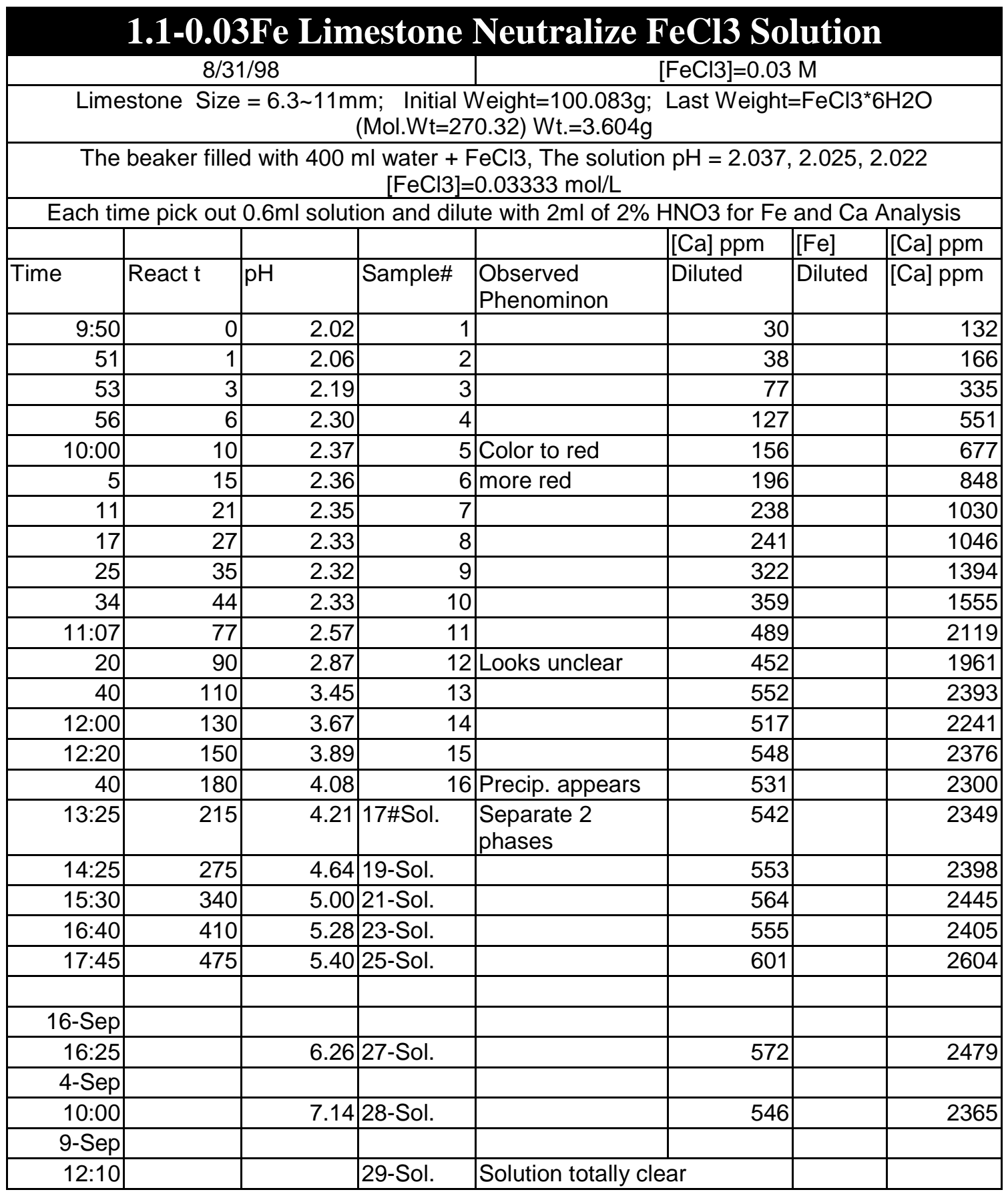


Appendix Table 7.4.4 The neutralization of $0.0 \mathrm{M}$ iron solutions $\left(\mathrm{FeCl}_{3}\right)$.

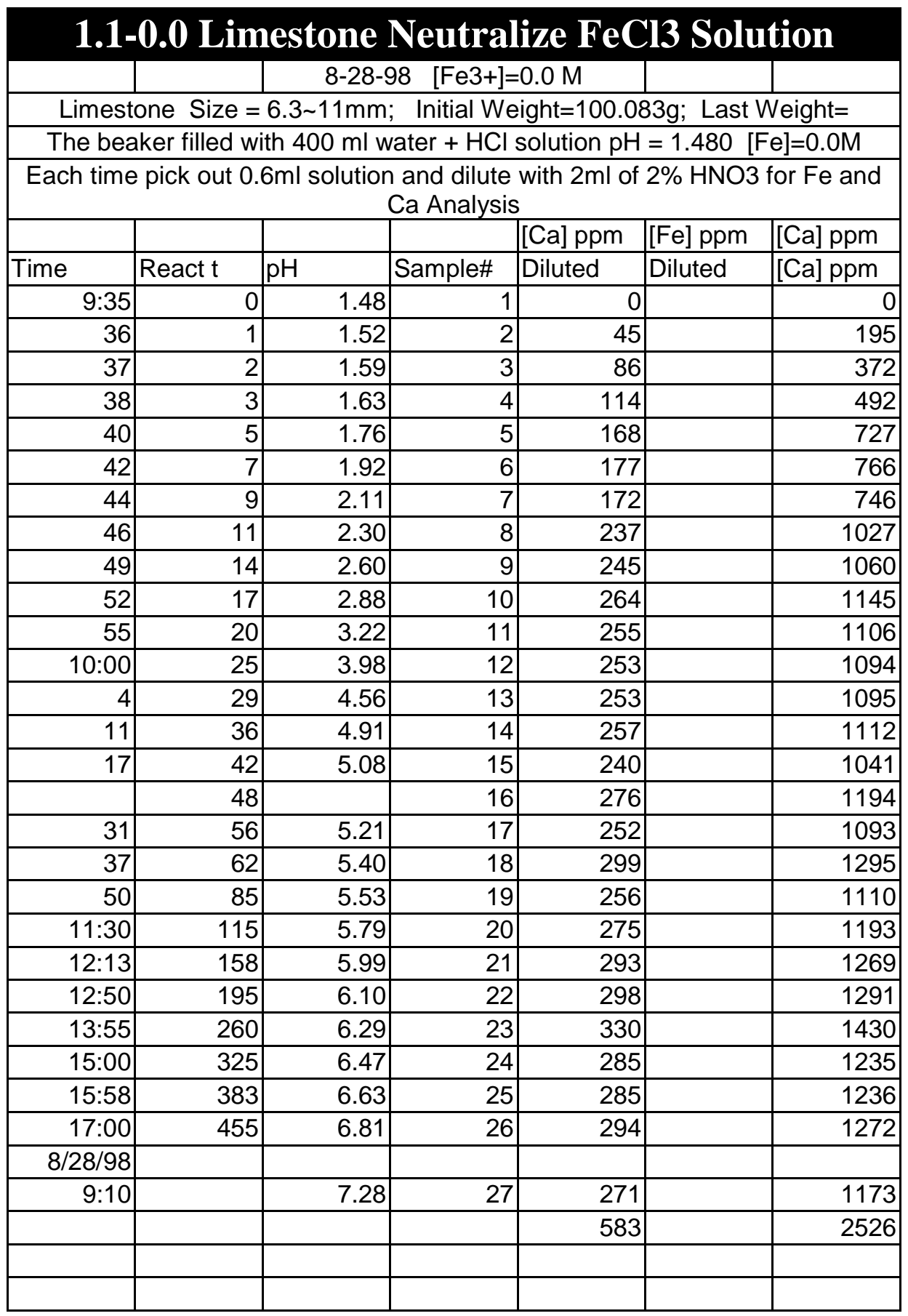


Appendix Table 7.4.8 The neutralization of $0.0005 \mathrm{M}$ iron solution by saran coated limestone.

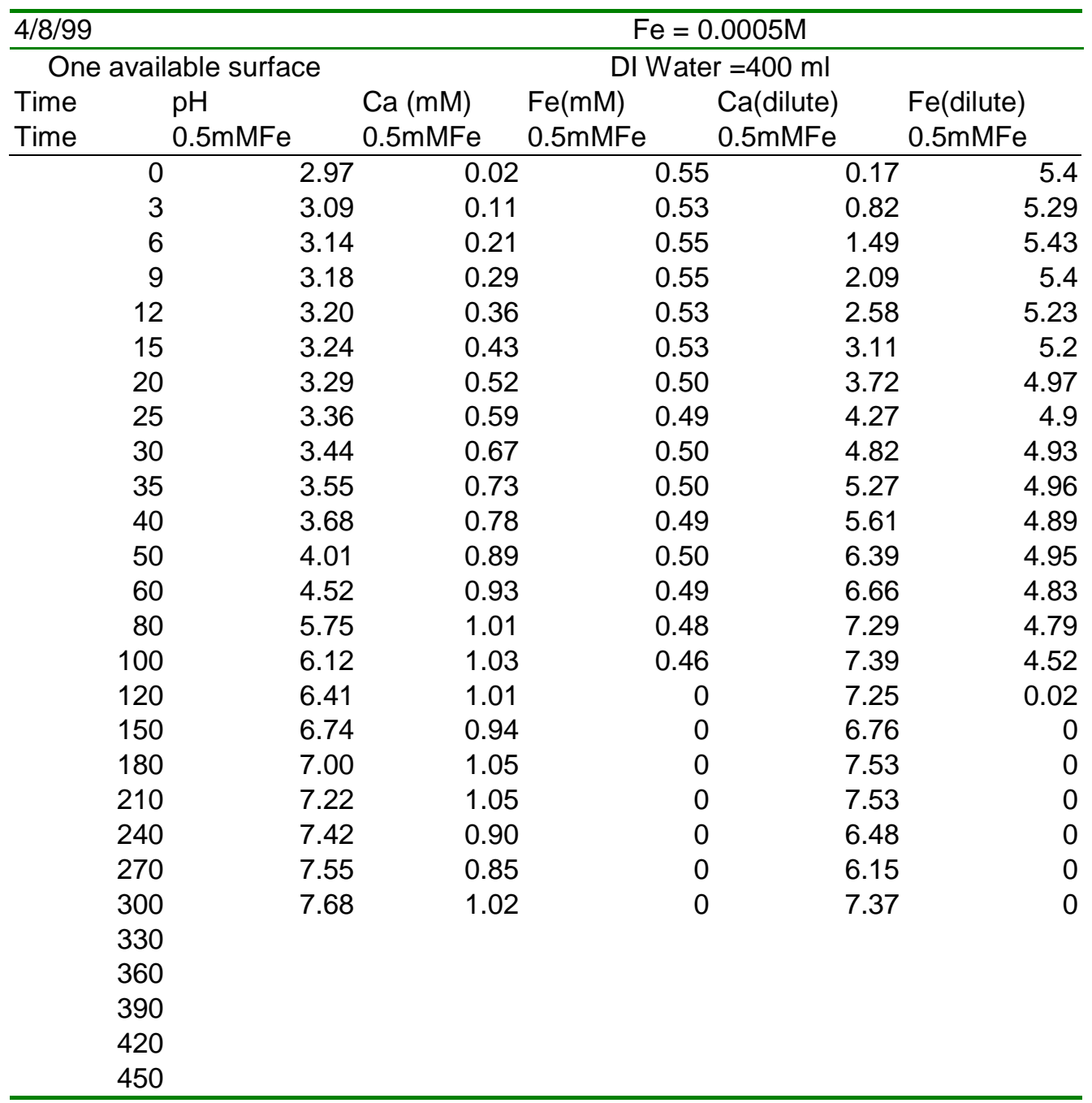


Appendix Table 7.4.9 The neutralization of $0.001 \mathrm{M}$ iron solution by saran coated limestone.

\begin{tabular}{|c|c|c|c|c|c|}
\hline $4 / 9 / 99$ & & & & & $e=0.001 M$ \\
\hline One availa & ole surface & & & & \\
\hline & DI Wa & ater $=500 \mathrm{ml}$ & $\mathrm{FeCl} 3=0.1$ & $108 \mathrm{~g}$ & \\
\hline Time & $\mathrm{pH}$ & $\mathrm{Ca}(\mathrm{mM})$ & $\mathrm{Fe}(\mathrm{mM})$ & Ca(dilute) & $\mathrm{Fe}$ (dilute) \\
\hline Time & $1 \mathrm{mMFe}$ & $1 \mathrm{mMFe}$ & $1 \mathrm{mMFe}$ & $1 \mathrm{mMFe}$ & $1 \mathrm{mMFe}$ \\
\hline 0 & 3.01 & 0.07 & 1.07 & 0.51 & 10.57 \\
\hline 3 & 3.14 & 0.11 & 1.05 & 0.79 & 10.41 \\
\hline 6 & 3.21 & 0.23 & 1.02 & 1.62 & 10.05 \\
\hline 9 & 3.23 & 0.33 & 0.97 & 2.41 & 9.62 \\
\hline 12 & 3.23 & 0.49 & 0.96 & 3.54 & 9.47 \\
\hline 15 & 3.24 & 0.55 & 0.96 & 3.98 & 9.5 \\
\hline 20 & 3.26 & 0.72 & 0.94 & 5.16 & 9.27 \\
\hline 25 & 3.30 & 0.89 & 0.93 & 6.43 & 9.23 \\
\hline 30 & 3.34 & 1.02 & 0.92 & 7.37 & 9.08 \\
\hline 35 & 3.41 & 1.14 & 0.89 & 8.23 & 8.85 \\
\hline 40 & 3.50 & 1.27 & 0.89 & 9.12 & 8.81 \\
\hline 50 & 3.78 & 1.54 & 0.88 & 11.07 & 8.68 \\
\hline 60 & 3.81 & 1.51 & 0.84 & 10.85 & 8.32 \\
\hline 80 & 4.73 & 1.75 & 0.85 & 12.58 & 8.42 \\
\hline 100 & 5.45 & 1.76 & 0.76 & 12.68 & 7.5 \\
\hline 120 & 5.88 & 1.61 & 0.51 & 11.61 & 5 \\
\hline 150 & 6.21 & 1.72 & 0 & 12.4 & 0 \\
\hline 180 & 6.41 & 1.73 & 0 & 12.42 & 0 \\
\hline 210 & 6.62 & 1.73 & 0 & 12.44 & 0 \\
\hline 240 & 6.83 & 1.88 & 0 & 13.57 & 0 \\
\hline 270 & 6.98 & 1.83 & 0 & 13.14 & 0 \\
\hline 300 & 7.13 & 1.82 & 0 & 13.09 & 0 \\
\hline 330 & 7.25 & 1.80 & 0 & 12.93 & 0 \\
\hline 360 & 7.39 & 1.82 & 0 & 13.13 & 0 \\
\hline 390 & 7.50 & 1.79 & 0 & 12.87 & 0 \\
\hline 420 & 7.60 & 1.74 & 0 & 12.54 & 0 \\
\hline
\end{tabular}


Appendix Table 7.4.10 The neutralization of $0.002 \mathrm{M}$ iron solution by saran coated limestone.

\begin{tabular}{|c|c|c|c|c|c|}
\hline \multicolumn{3}{|c|}{$4 / 28 / 99$} & \multicolumn{3}{|c|}{$\mathrm{Fe}=0.002 \mathrm{M}$} \\
\hline \multicolumn{6}{|c|}{ One available surface } \\
\hline \multirow{3}{*}{\multicolumn{6}{|c|}{$\begin{array}{l}\text { DI Water }=400 \mathrm{~mL} \\
{ }^{*} \text { Note: Dilution is } 4.1: 0.9 \mathrm{ml} \text {. For Fe sample } 0-15 \\
\text { (up to } 120 \mathrm{~min} \text { ) diluted again at } 0.75: 0.75 \mathrm{ml}\end{array}$}} \\
\hline & & & & & \\
\hline & & & & & \\
\hline Time & $\mathrm{pH}$ & $\mathrm{Ca}(\mathrm{mM})$ & $\mathrm{Fe}(\mathrm{mM})$ & $\mathrm{Ca}$ (dilute) & $\mathrm{Fe}$ (dilute) \\
\hline Time & $2 \mathrm{mMFe}$ & $2 \mathrm{mMFe}$ & $2 \mathrm{mMFe}$ & $2 \mathrm{mMFe}$ & 2mMFe \\
\hline 0 & 2.99 & 0.00 & 2.16 & 0.02 & 10.68 \\
\hline 3 & 2.97 & 0.30 & 2.16 & 2.13 & 10.68 \\
\hline 6 & 3.02 & 0.51 & 2.07 & 3.70 & 10.24 \\
\hline 9 & 3.02 & 0.73 & 2.08 & 5.22 & 10.29 \\
\hline 12 & 3.00 & 0.90 & 2.05 & 6.46 & 10.14 \\
\hline 15 & 2.98 & 1.08 & 2.00 & 7.80 & 9.89 \\
\hline 20 & 2.96 & 1.33 & 1.97 & 9.54 & 9.76 \\
\hline 25 & 2.96 & 1.61 & 1.96 & 11.59 & 9.69 \\
\hline 30 & 2.97 & 1.80 & 1.93 & 12.96 & 9.57 \\
\hline 35 & 2.99 & 2.09 & 1.98 & 15.02 & 9.81 \\
\hline 40 & 3.01 & 2.17 & 1.89 & 15.60 & 9.34 \\
\hline 50 & 3.09 & 2.62 & 1.98 & 18.88 & 9.81 \\
\hline 60 & 3.25 & 2.78 & 1.86 & 20.02 & 9.21 \\
\hline 80 & 3.72 & 3.12 & 1.85 & 22.45 & 9.16 \\
\hline 105 & 4.68 & 2.80 & 1.54 & 20.17 & 7.61 \\
\hline 120 & 5.21 & 2.50 & 1.41 & 17.99 & 6.97 \\
\hline 150 & 5.56 & 2.60 & 1.01 & 18.76 & 5 \\
\hline 180 & 5.92 & 2.71 & 0 & 19.52 & 0 \\
\hline 210 & 6.14 & 2.77 & 0 & 19.93 & 0 \\
\hline 240 & 6.35 & 3.40 & 0 & 24.51 & 0 \\
\hline 270 & 6.54 & 3.19 & 0 & 23.00 & 0 \\
\hline 300 & 6.73 & 3.14 & 0 & 22.61 & 0 \\
\hline 330 & 6.87 & 3.09 & 0 & 22.26 & 0 \\
\hline 360 & 7.00 & 3.57 & 0 & 25.70 & 0 \\
\hline 390 & 7.12 & 3.32 & 0 & 23.89 & 0 \\
\hline 420 & & & & & \\
\hline
\end{tabular}


Appendix Table 7.4.11 The neutralization of $0.004 \mathrm{M}$ iron solution by saran coated limestone.

\begin{tabular}{|c|c|c|c|c|c|}
\hline \multicolumn{3}{|l|}{ 4/27/99 } & \multicolumn{3}{|c|}{$\begin{array}{c}\mathrm{Fe}= \\
0.004 \mathrm{M}\end{array}$} \\
\hline \multicolumn{6}{|c|}{$\begin{array}{r}{ }^{*} \text { Note: Dilution is } 4.1: 0.9 \mathrm{ml} \text {. For Fe diluted again at } 2.7: 0.9 \mathrm{ml} \\
\text { One available surface }\end{array}$} \\
\hline & DI Wate & $\mathrm{er}=400 \mathrm{~mL}$ & & & $\mathrm{FeCl} 3=$ \\
\hline Time & $\mathrm{pH}$ & $\mathrm{Ca}(\mathrm{mM})$ & $\mathrm{Fe}(\mathrm{mM})$ & $\mathrm{Ca}$ (dilute) & Fe(dilute) \\
\hline Time & 4.5mMFe & 4.5mMFe & 4.5mMFe & 4.5mMFe & 4.5mMFe \\
\hline 0 & 2.70 & 0.02 & 4.46 & $\quad 0.17$ & 11.04 \\
\hline 3 & 2.73 & 0.34 & 4.42 & 2.47 & 10.93 \\
\hline 7 & 2.78 & 0.64 & 4.41 & 4.59 & 10.91 \\
\hline 9 & 2.80 & 0.79 & 4.37 & 5.67 & 10.81 \\
\hline 11 & 2.82 & 0.98 & 4.55 & 7.06 & 11.27 \\
\hline 15 & 2.84 & 1.18 & 4.37 & 8.49 & 10.82 \\
\hline 20 & 2.84 & 1.67 & 4.33 & 12.01 & 10.72 \\
\hline 25 & 2.81 & 2.08 & 3.63 & 15.02 & 8.98 \\
\hline 30 & 2.79 & 2.36 & 3.09 & 17.10 & 7.66 \\
\hline 35 & 2.77 & 2.50 & 3.07 & 18.20 & 7.60 \\
\hline 40 & 2.76 & 2.78 & 3.19 & 20.12 & 7.90 \\
\hline 50 & 2.75 & 3.19 & 3.43 & 23.11 & 8.50 \\
\hline 60 & 2.75 & 3.47 & 3.30 & 25.00 & 8.16 \\
\hline 80 & 2.78 & 3.75 & 3.25 & 27.02 & 8.04 \\
\hline 100 & 2.84 & 3.84 & 3.22 & 27.64 & 7.98 \\
\hline 120 & 2.97 & 4.72 & 3.17 & 34.04 & 7.85 \\
\hline 150 & 3.26 & 4.74 & 3.05 & 34.10 & 7.54 \\
\hline 180 & 3.80 & 5.13 & 3.13 & 36.92 & 7.75 \\
\hline 210 & 4.44 & 5.14 & 3.01 & 37.03 & 7.46 \\
\hline 240 & 4.94 & 4.86 & 1.31 & 35.09 & 3.23 \\
\hline 270 & 5.21 & 4.72 & 0.21 & 34.01 & 0.72 \\
\hline 300 & 5.39 & 4.86 & 0.07 & 35.03 & 0.18 \\
\hline 330 & 5.56 & 5.30 & 0 & 38.16 & 0 \\
\hline 360 & 5.75 & 5.40 & 0 & 38.87 & 0 \\
\hline 390 & 5.94 & 5.33 & 0 & 38.36 & 0 \\
\hline
\end{tabular}


Appendix Table 7.4.12 The neutralization of $0.008 \mathrm{M}$ iron solution by saran coated limestone.

\begin{tabular}{|c|c|c|c|c|c|}
\hline \multicolumn{3}{|c|}{$4 / 23 / 99$} & \multicolumn{3}{|c|}{$\mathrm{Fe}=0.008 \mathrm{M}$} \\
\hline \multicolumn{6}{|c|}{ One available surface } \\
\hline $\begin{array}{r}\text { *Note: D } \\
0.5\end{array}$ & $\begin{array}{l}\text { DI Water } \\
400 \mathrm{ml} \\
\text { ttion is } 4.1 \text { : } \\
0.9 \mathrm{ml} \text {. Fe se }\end{array}$ & $\begin{array}{l}.9 \mathrm{ml} \text {. For } \\
\text { Imples } 0-21\end{array}$ & $\begin{array}{l}\text { a diluted } s \\
\text { diluted ag }\end{array}$ & $\begin{array}{c}\mathrm{FeCl} 3= \\
.865 \mathrm{~g} \\
\text { amples 14- } \\
\text { ain at } 4.5: 0 \text {. }\end{array}$ & $\begin{array}{l}26 \text { again at } \\
75 \mathrm{ml}\end{array}$ \\
\hline Time & $\mathrm{pH}$ & $\mathrm{Ca}(\mathrm{mM})$ & $\mathrm{Fe}(\mathrm{mM})$ & Ca(dilute) & $\mathrm{Fe}$ (dilute) \\
\hline Time & $10 \mathrm{mMFe}$ & $10 \mathrm{mMFe}$ & $10 \mathrm{mMFe}$ & $10 \mathrm{mMFe}$ & $10 \mathrm{mMFe}$ \\
\hline 0 & 2.44 & 0.04 & 9.87 & 0.14 & 13.96 \\
\hline 3 & 2.51 & 1.33 & 9.76 & 4.79 & 13.80 \\
\hline 6 & 2.57 & 2.37 & 9.81 & 8.53 & 13.87 \\
\hline 9 & 2.62 & 3.15 & 9.79 & 11.34 & 13.84 \\
\hline 12 & 2.66 & 3.81 & 9.59 & 13.73 & 13.56 \\
\hline 15 & 2.70 & 4.34 & 9.34 & 15.62 & 13.21 \\
\hline 20 & 2.74 & 4.78 & 9.33 & 17.20 & 13.20 \\
\hline 25 & 2.74 & 5.59 & 9.35 & 20.14 & 13.22 \\
\hline 30 & 2.70 & 6.39 & 8.90 & 23.02 & 12.59 \\
\hline 35 & 2.67 & 7.19 & 9.09 & 25.87 & 12.86 \\
\hline 40 & 2.64 & 8.48 & 9.05 & 30.54 & 12.81 \\
\hline 50 & 2.60 & 8.60 & 8.41 & 28.64 & 11.92 \\
\hline 60 & 2.57 & 9.31 & 8.34 & 33.50 & 11.85 \\
\hline 80 & 2.56 & 9.30 & 8.41 & 39.21 & 11.91 \\
\hline 100 & 2.59 & 10.00 & 7.99 & 28.92 & 11.30 \\
\hline 120 & 2.65 & 10.10 & 7.85 & 30.54 & 11.19 \\
\hline 150 & 2.68 & 10.26 & 7.92 & 36.94 & 11.21 \\
\hline 180 & 3.20 & 11.46 & 8.07 & 41.26 & 11.42 \\
\hline 210 & 3.66 & 11.13 & 7.53 & 40.07 & 10.65 \\
\hline 240 & 4.12 & 11.40 & 6.98 & 38.87 & 9.87 \\
\hline 270 & 4.49 & 11.45 & 6.38 & 37.68 & 9.02 \\
\hline 300 & 4.78 & 11.80 & 2.69 & 39.17 & 3.81 \\
\hline 330 & 5.00 & 10.90 & 0.54 & 35.58 & 0.76 \\
\hline 360 & 5.14 & 11.39 & 0 & 41.02 & 0 \\
\hline 390 & 5.28 & 12.30 & 0 & 38.04 & 0 \\
\hline 420 & 5.36 & 12.03 & 0 & 43.31 & 0 \\
\hline 450 & 5.45 & 13.49 & 0 & 48.57 & 0 \\
\hline
\end{tabular}


Appendix Table 7.5.1 The neutralization iron solution by 0M Fe coated limestone.

\begin{tabular}{|c|c|c|c|c|c|}
\hline \multicolumn{6}{|c|}{ Fe solution by limestone of one available surface } \\
\hline & & \multicolumn{2}{|c|}{ DI Water $=500 \mathrm{ml}$} & \multicolumn{2}{|c|}{$\mathrm{FeCl} 3=0.108 \mathrm{~g}$} \\
\hline & & $4 / 9 / 99$ & & $\mathrm{Fe}=0.001 \mathrm{M}$ & \\
\hline & $\mathrm{pH}$ & $\mathrm{Ca}$ (dilute) & Fe(dilute) & $\mathrm{Ca}(\mathrm{mmol} / \mathrm{L})$ & $\mathrm{Fe}(\mathrm{mmol} / \mathrm{L})$ \\
\hline Time & 0-coat & 0-coat & 0 -coat & 0 -coat & 0-coat \\
\hline 0 & 3.01 & \begin{tabular}{|l|}
0.51 \\
\end{tabular} & 10.57 & 52 & 1468 \\
\hline 3 & 3.14 & 0.79 & 10.41 & 80 & 1446 \\
\hline 6 & 3.21 & 1.62 & 10.05 & 164 & 1396 \\
\hline 9 & 3.23 & 2.41 & 9.62 & 243 & 1336 \\
\hline 12 & 3.23 & 3.54 & 9.47 & 358 & 1315 \\
\hline 15 & 3.24 & 3.98 & 9.50 & 402 & 1319 \\
\hline 20 & 3.26 & 5.16 & 9.27 & 521 & 1288 \\
\hline 25 & 3.30 & 6.43 & 9.23 & 649 & 1282 \\
\hline 30 & 3.34 & 7.37 & 9.08 & 744 & 1261 \\
\hline 35 & 3.41 & 8.23 & 8.85 & 831 & 1229 \\
\hline 40 & 3.50 & 9.12 & 8.81 & 921 & 1224 \\
\hline 50 & 3.70 & 11.07 & 8.68 & 1118 & 1206 \\
\hline 60 & 4.01 & 10.85 & 8.32 & 1096 & 1156 \\
\hline 80 & 4.73 & 12.58 & 8.42 & 1271 & 1169 \\
\hline 100 & 5.45 & 12.68 & 0.50 & 1281 & 69 \\
\hline 120 & 5.88 & 11.61 & 0 & 1173 & 0 \\
\hline 150 & 6.21 & 12.40 & 0 & 1253 & 0 \\
\hline 180 & 6.41 & 12.42 & 0 & 1255 & 0 \\
\hline 210 & 6.62 & 12.44 & 0 & 1257 & 0 \\
\hline 240 & 6.83 & 13.57 & 0 & 1371 & 0 \\
\hline 270 & 6.98 & 13.14 & 0 & 1327 & 0 \\
\hline 300 & 7.13 & 13.09 & 0 & 1322 & 0 \\
\hline 330 & 7.25 & 12.93 & 0 & 1306 & 0 \\
\hline 360 & 7.39 & 13.13 & 0 & 1326 & 0 \\
\hline 390 & 7.50 & 12.87 & 0 & 1300 & 0 \\
\hline 420 & 7.60 & 12.54 & 0 & 1267 & 0 \\
\hline 450 & & & & & \\
\hline
\end{tabular}


Appendix Table 7.5.2 The neutralization iron solution by $0.002 \mathrm{M}$ Fe coated limestone.

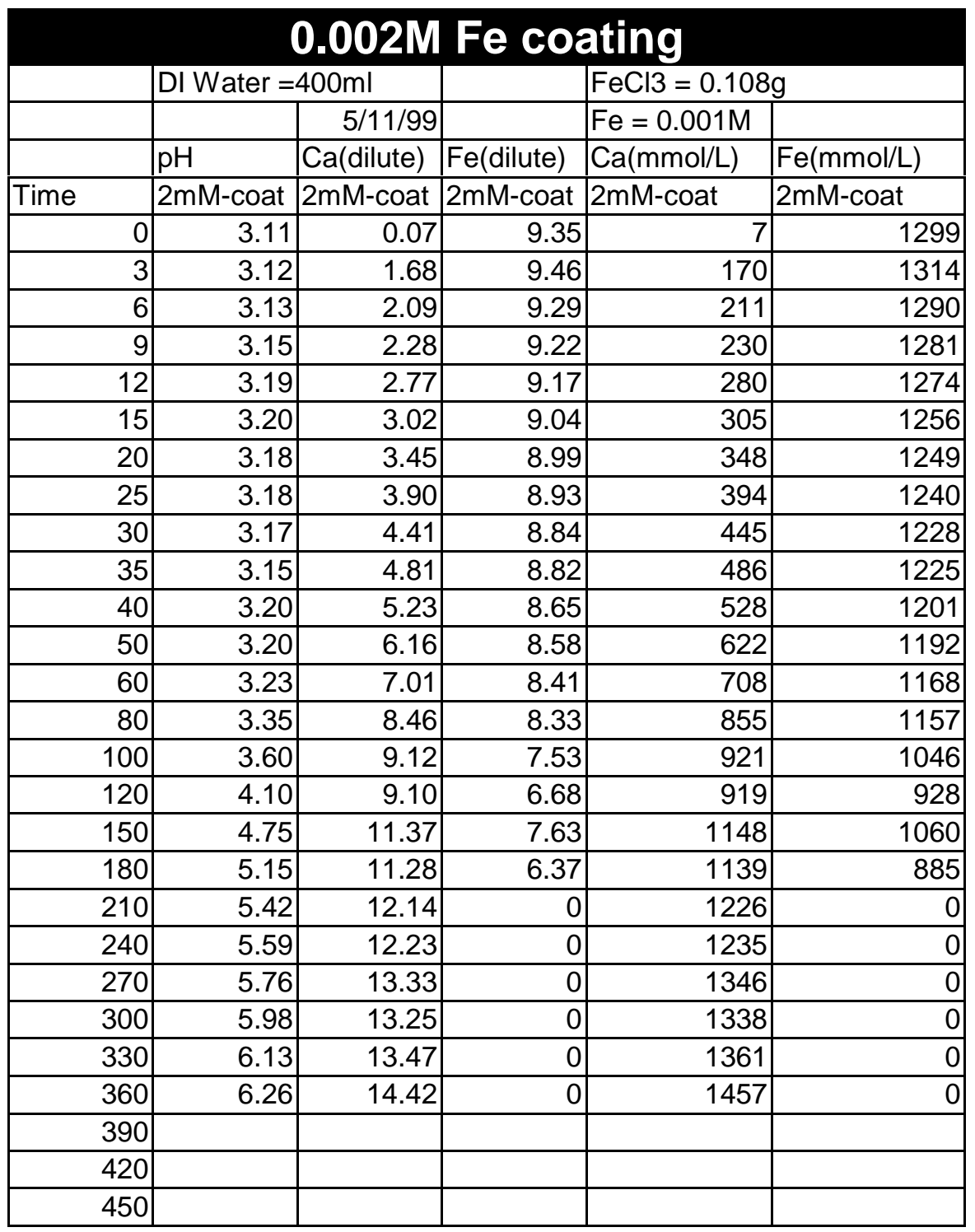


Appendix Table 7.5.3 The neutralization iron solution by $0.004 \mathrm{M}$ Fe coated limestone.

\begin{tabular}{|c|c|c|c|c|c|}
\hline \multicolumn{6}{|c|}{$0.004 \mathrm{M}$ Fe coating } \\
\hline \multirow{3}{*}{$5 / 12 / 99$} & \multicolumn{2}{|c|}{ DI Water $=400 \mathrm{ml}$} & \multicolumn{3}{|c|}{\begin{tabular}{|l|l|} 
& $\mathrm{FeCl} 3=0.108 \mathrm{~g}$
\end{tabular}} \\
\hline & \multirow{2}{*}{$\mathrm{pH}$} & \multirow[b]{2}{*}{ Ca(dilute) } & \multicolumn{3}{|c|}{$\mathrm{Fe}=0.001 \mathrm{M}$} \\
\hline & & & Fe(dilute) & $\mathrm{Ca}(\mathrm{mmol} / \mathrm{L})$ & $\mathrm{Fe}(\mathrm{mmol} / \mathrm{L})$ \\
\hline Time & $4 \mathrm{mM}$-coat & $4 \mathrm{mM}$-coat & $4 \mathrm{mM}$-coat & $4 \mathrm{mM}-$ coat & $4 \mathrm{mM}$-coat \\
\hline$\overline{0}$ & 3.11 & 0.09 & 10.43 & 9 & 1449 \\
\hline 3 & 3.13 & 7.51 & 10.25 & 759 & 1424 \\
\hline 6 & 3.14 & 7.84 & 10.09 & 792 & 1402 \\
\hline 9 & 3.15 & 8.29 & 9.99 & 837 & 1387 \\
\hline 12 & 3.15 & 8.30 & 9.84 & 838 & 1367 \\
\hline 15 & 3.15 & 8.93 & 9.72 & 902 & 1350 \\
\hline 20 & 3.14 & 9.54 & 9.56 & 964 & 1328 \\
\hline 25 & 3.13 & 10.16 & 9.41 & 1026 & 1307 \\
\hline 30 & 3.12 & 10.68 & 9.42 & 1079 & 1309 \\
\hline 35 & 3.11 & 11.25 & 9.25 & 1136 & 1285 \\
\hline 40 & 3.11 & 11.74 & 9.14 & 1186 & 1270 \\
\hline 50 & 3.12 & 12.63 & 8.82 & 1276 & 1225 \\
\hline 60 & 3.14 & 13.90 & 8.92 & 1404 & 1238 \\
\hline 80 & 3.15 & 15.62 & 8.31 & 1578 & 115 \\
\hline 100 & 3.19 & 17.06 & 8.79 & 1723 & 1221 \\
\hline 120 & 3.25 & 18.16 & 8.26 & 1834 & 1147 \\
\hline 150 & 3.60 & 18.95 & 7.94 & 1914 & 1102 \\
\hline 180 & 4.10 & 19.75 & 7.69 & 1995 & 1069 \\
\hline 210 & 4.45 & 20.14 & 6.95 & 2034 & 966 \\
\hline 240 & 4.70 & 20.52 & 6.95 & 2073 & 966 \\
\hline 270 & 4.90 & 20.76 & 0.00 & 2097 & 0 \\
\hline 300 & 5.10 & & & & \\
\hline 330 & 5.30 & & & & \\
\hline 360 & 5.40 & & & & \\
\hline 390 & & & & & \\
\hline 420 & & & & & \\
\hline 450 & & & & & \\
\hline
\end{tabular}


Appendix Table 7.5.4 The neutralization iron solution by $0.006 \mathrm{M}$ Fe coated limestone.

\begin{tabular}{|c|c|c|c|c|c|}
\hline & & $.006 N$ & Fe coe & ting & \\
\hline & DI Water = & 200ml & & $\mathrm{FeCl} 3=0.054$ & \\
\hline $5 / 6 / 99$ & & & $\mathrm{Fe}=0.001$ & & \\
\hline & $\mathrm{pH}$ & $\mathrm{Ca}$ (dilute) & $\mathrm{Fe}$ (dilute) & $\mathrm{Ca}(\mathrm{mmol} / \mathrm{L})$ & $\mathrm{Fe}(\mathrm{mmol} / \mathrm{L})$ \\
\hline Time & $6 \mathrm{mM}$-coat & 6mM-coat & 6mM-coat & 6mM-coat & $6 \mathrm{mM}$-coat \\
\hline 0 & 3.00 & 0.18 & 10.62 & 18 & 1475 \\
\hline 3 & 3.00 & 5.66 & 10.52 & 572 & 1461 \\
\hline 6 & 3.01 & 5.91 & 10.78 & 597 & 1497 \\
\hline 9 & 3.01 & 6.22 & 10.68 & 628 & 1483 \\
\hline 12 & 3.01 & 6.52 & 10.71 & 659 & 1488 \\
\hline 15 & 3.01 & 6.65 & 10.65 & 672 & 1479 \\
\hline 20 & 3.01 & 7.00 & 10.65 & 707 & 1479 \\
\hline 25 & 3.01 & 7.49 & 10.85 & 757 & 1507 \\
\hline 30 & 3.01 & 7.64 & 10.68 & 772 & 1483 \\
\hline 35 & 3.01 & 7.90 & 10.62 & 798 & 1475 \\
\hline 40 & 3.00 & 8.16 & 10.37 & 824 & 1440 \\
\hline 50 & 3.00 & 8.95 & 10.49 & 904 & 1457 \\
\hline 60 & 2.99 & 9.51 & 10.34 & 961 & 1436 \\
\hline 80 & 2.98 & 11.63 & 10.26 & 1175 & 1425 \\
\hline 100 & 3.02 & 11.17 & 9.15 & 1128 & 1271 \\
\hline 120 & 3.05 & 12.15 & 8.99 & 1227 & 1249 \\
\hline 150 & 3.14 & 14.83 & 9.55 & 1498 & 1326 \\
\hline 180 & 3.27 & 15.65 & 9.37 & 1581 & 1301 \\
\hline 210 & 3.45 & 17.38 & 9.49 & 1756 & 1318 \\
\hline 240 & 3.64 & 17.42 & 9.12 & 1760 & 1267 \\
\hline 270 & 3.92 & 17.99 & 8.85 & 1817 & 1229 \\
\hline 300 & 4.12 & 16.58 & 7.24 & 1675 & 1006 \\
\hline 330 & 4.23 & 19.95 & 0 & 2015 & $\overline{0}$ \\
\hline 360 & 4.36 & 20.29 & 0 & 2049 & 0 \\
\hline 390 & & & & & \\
\hline 420 & & & & & \\
\hline 450 & & & & & \\
\hline
\end{tabular}


Appendix Table 7.5.5 $\mathrm{pH}$ changing rate.

\begin{tabular}{|c|c|c|c|c|}
\hline \multicolumn{5}{|c|}{$\begin{array}{l}\text { pH changes as the reac } \\
\qquad(\mathrm{dpH} / \mathrm{dt})\end{array}$} \\
\hline Time & OCoat & 2coat & 4coat & 6 coat \\
\hline 0 & 0.0460 & 0.0030 & 0.0062 & 0.0003 \\
\hline 3 & 0.0210 & 0.0033 & 0.0042 & 0.0023 \\
\hline 6 & 0.0077 & 0.0067 & 0.0020 & 0.0010 \\
\hline 9 & 0.0003 & 0.0133 & 0.0000 & 0.0003 \\
\hline 12 & 0.0017 & 0.0033 & -0.0011 & -0.0003 \\
\hline 15 & 0.0040 & -0.0042 & -0.0017 & -0.0006 \\
\hline 20 & 0.0080 & -0.0008 & -0.0023 & 0.0004 \\
\hline 25 & 0.0090 & -0.0010 & -0.0016 & -0.0008 \\
\hline 30 & 0.0132 & -0.0040 & -0.0007 & -0.0002 \\
\hline 35 & 0.0182 & & 0.0000 & -0.0010 \\
\hline 40 & 0.0203 & 0.0007 & 0.0007 & -0.0004 \\
\hline 50 & 0.0310 & 0.0024 & 0.0017 & -0.0004 \\
\hline 60 & 0.0362 & 0.0062 & 0.0006 & -0.0008 \\
\hline 80 & 0.0359 & 0.0125 & 0.0020 & 0.0021 \\
\hline 100 & 0.0215 & 0.0250 & 0.0030 & 0.0017 \\
\hline 120 & 0.0108 & 0.0217 & 0.0117 & 0.0031 \\
\hline 150 & 0.0070 & 0.0133 & 0.0167 & 0.0041 \\
\hline 180 & 0.0070 & 0.0091 & 0.0117 & 0.0060 \\
\hline 210 & 0.0069 & 0.0056 & 0.0083 & 0.0064 \\
\hline 240 & 0.0049 & 0.0057 & 0.0067 & 0.0093 \\
\hline 270 & 0.0052 & 0.0074 & 0.0067 & 0.0068 \\
\hline 300 & 0.0039 & 0.0048 & 0.0067 & 0.0037 \\
\hline 330 & 0.0047 & 0.0044 & 0.0033 & 0.0042 \\
\hline
\end{tabular}

Appendix Table 7.5.6 Coating thickness vs. iron concentration.

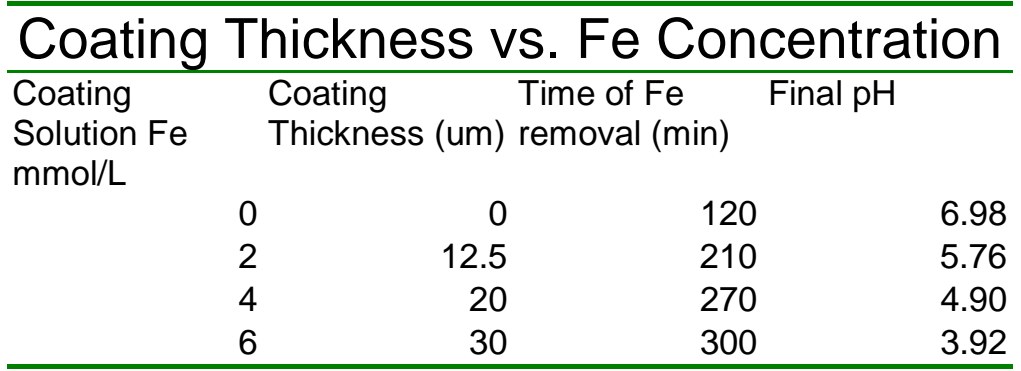




\section{VITA}

Name

Qingyun Sun

Birth Date

May 22, 1962

Birth Place

Xuzhou, China

Education

Xuzhou $10^{\text {th }}$ High School

$1975-1980$

China University of Mining \& Technology, Xuzhou

1980-1984

China University of Mining \& Technology, Beijing

1987-1990

$\underline{\text { Degree Received }}$

Bachelor of Chemical Engineering

China University of Mining \& Technology

1984

Master of Science of Environmental Engineering

China University of Mining \& Technology .

1990 